\title{
DESIGN AND OPERATIONS MANUAL PRESSURIZED IRRIGATION SYSTEMS VOLUME I
}

\author{
Shehzad Ahmad ${ }^{1}$, Ali Ajaz ${ }^{2}$
}

${ }^{1}$ Design Engineer (HEIS) ${ }^{2}$ Assistant Design Engineer (HEIS)

Document type: Technical Report

Volume: I

Publisher: Project- Implementation Supervision Consultants (PSC)

Month Published: December, 2013

DOI: 10.13140/RG.2.2.14110.18244

DESIGN AND OPERATIONS MANUAL

PRESSURIZED IRRIGATION SYSTEMS

VOLUME I

Technical Team

Shehzad Ahmad

Design Engineer (HEIS)

Ali Ajaz

Assistant Design Engineer (HEIS)

Principal Editor

Project Manager

December 2013,

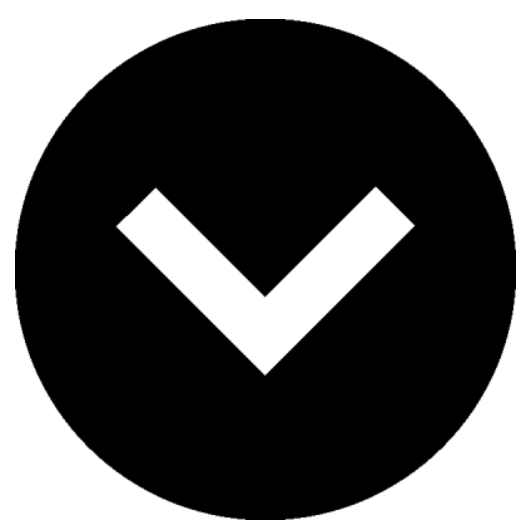




\title{
DESIGN AND OPERATIONS MANUAL PRESSURIZED IRRIGATION SYSTEMS
}

\author{
VOLUME I
}

\section{Technical Team}

Shehzad Ahmad

Design Engineer (HEIS)

Ali Ajaz

Assistant Design Engineer (HEIS)

\section{Principal Editor}

Project Manager

December 2013, Lahore, Pakistan

\section{Project- Implementation Supervision Consultants (PSC) A Joint Venture of NESPAK and NDC}




\section{PREFACE}

This manual covers the technical design and operational aspects of high efficiency (pressurized) irrigation system in a brief and comprehensive way. The first volume covers a detail discussion of pressurized irrigation systems including their classifications, selection criteria and components followed by basics of design. Design proforma for design of drip and sprinkler irrigation system has been discussed in detail covering the procedure for collection of necessary field data required for proper system design. Hydraulic principles have also been covered in detail for proper selection of pipe network and pumping unit. Design

procedure has been elaborated with solved examples. Second volume of this manual covers the operational part of pressurized irrigation systems, which includes general maintenance and tips for durability and sustainability of high efficiency irrigation system equipments. It also covers the vigilance and checking during system operation, care after completing a crop season, care of prime movers, system re-adjustments, clogging and its remedies, chemigation including acid treatment and chlorination, maintenance tips of water storage tanks, general trouble shooting and remedies. A list of tables and diagrams is also provided for the ease of users. This manual will provide a general guideline to project technical staff and contractors for proper design and smooth field operations of high efficiency irrigation system sites and it will also be helpful for effective post installation services and getting the desired results from high efficiency irrigation systems. 


\section{DESIGN OPERATION AND MAINTENANCE MANUAL \\ FOR}

HIGH EFFICIENCY IRRIGATION SYSTEMS

\section{TABLE OF CONTENTS}

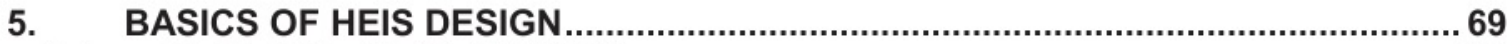

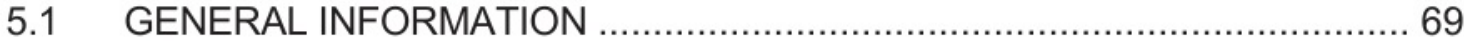

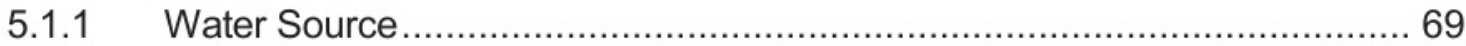

5.2 FIELD LAYOUT AND TOPOGRAPHY ................................................. 71

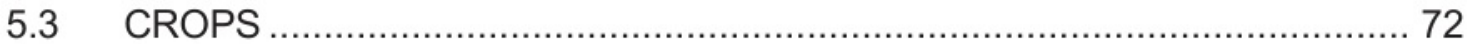

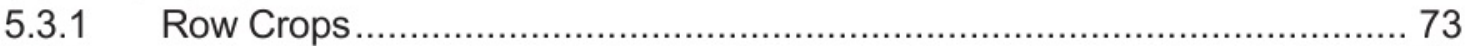

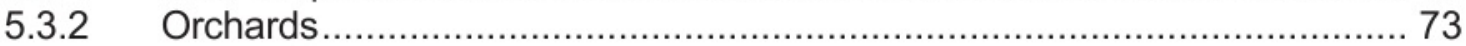

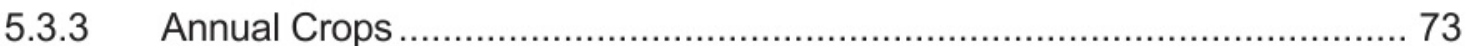

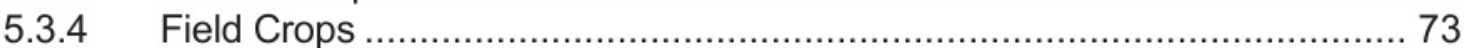

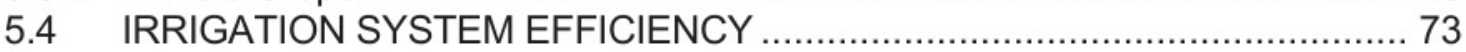

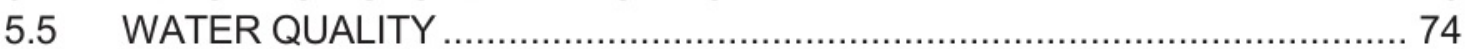

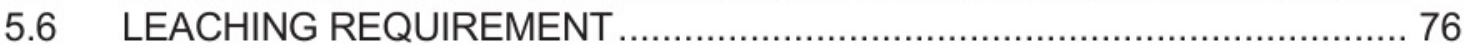

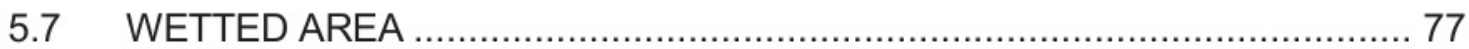

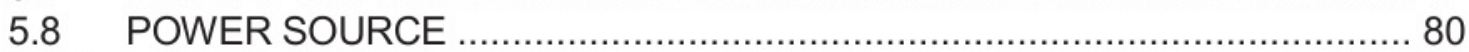

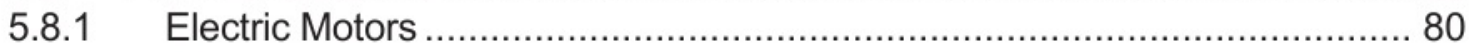

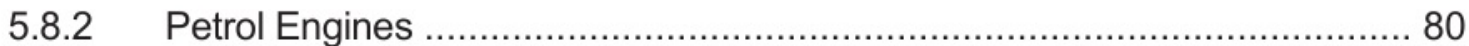

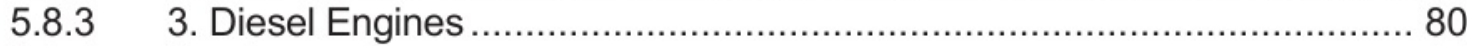

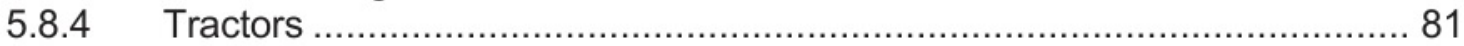

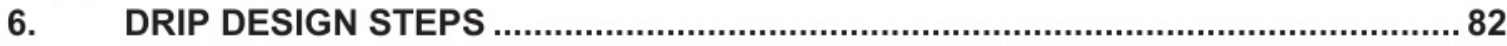

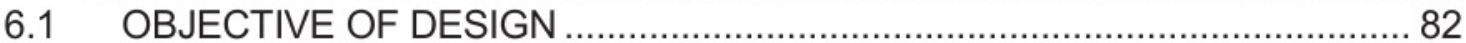

6.2 DRIP DESIGN PROCEDURE-STEP BY STEP (ORCHARD) ....................... 83

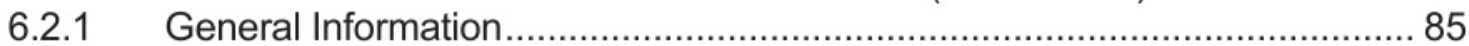

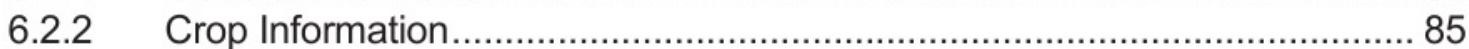

6.2.3 Soil Type/Soil Test/Water Supply/Water Quality ...................................... 86

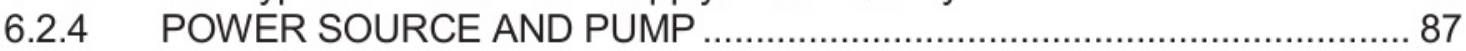

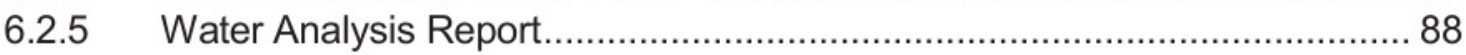

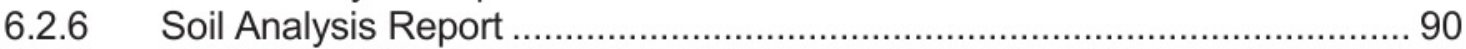

6.2.7 Estimation of Peak Crop Water Requirement ......................................... 92

6.2.8 Drawing of Project Area, Selection of zone area and No. of Operations ..... 92

6.2.9 Step 4. SELECTION OF EMITTER/DRIPPER AND FLOW RATE .............. 92

6.2.10 No. of Emitters per Plant, No. of Drip Lines per Row and optimal Distance between two Laterals..... 98

6.2.11 Calculation of Plant Area and Total Number of Plants and Minimum No. of Emitters per plant ........ 98

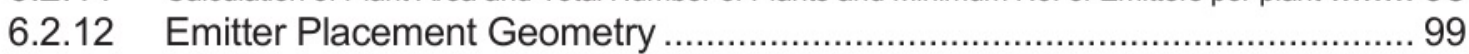

6.2.13 Calculation Of Total Length Of Lateral, Number Of Emitters In One Zone And Total Number Of Emitters ....... 101

6.2.14 Calculation of Total Flow Rate Requirements (Iph) ............................... 103

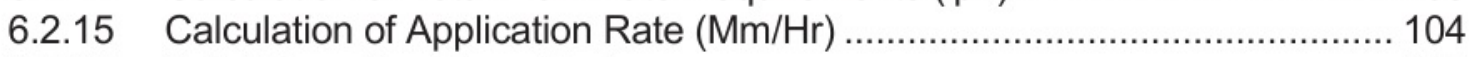

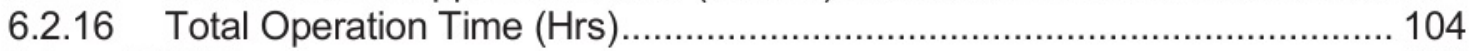

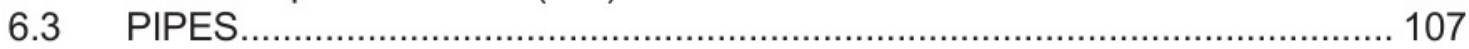

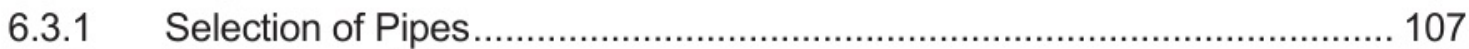

6.3.2 Fiber Cement Pipes................................................................................... 108

6.3.3 Un-plasticized Polyvinyl Chloride Pipes (UPVC) ................................... 109

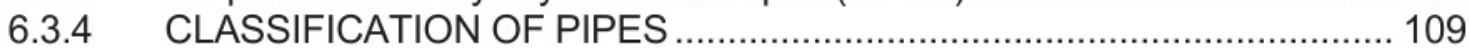

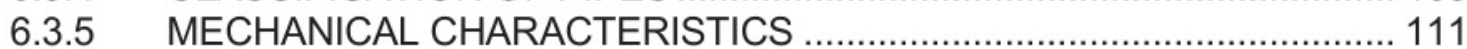

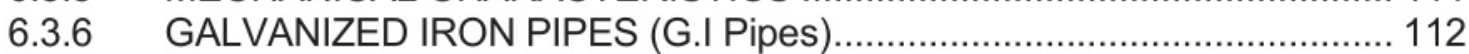

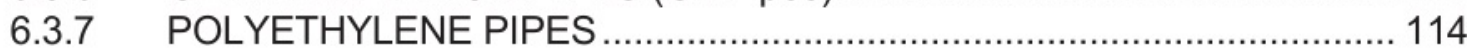

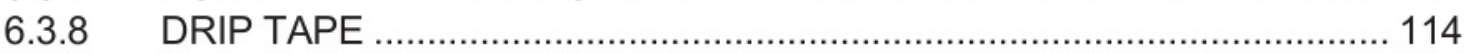

Project - Implementation Supervision Consultants (PISC) 


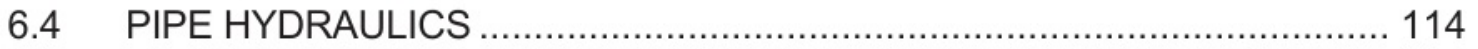

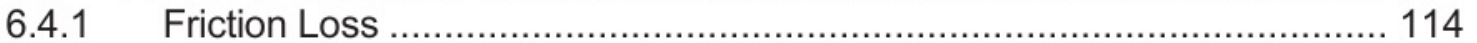

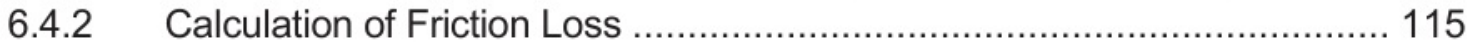

6.4.3 Hazen-Williams Equation ............................................................ 115

6.4.4 Watters \& Keller Equation ............................................................ 116

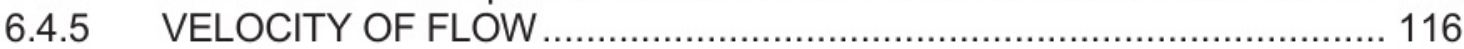

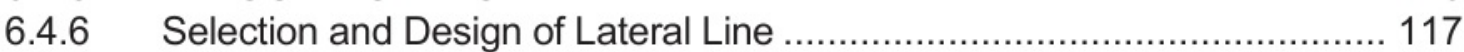

6.4.7 DESIGN OF SUB-MAIN LINE ................................................. 119

6.4.8 Selection and Design of mainline ............................................ 121

6.4.9 HEAD LOSS THROUGH FITTINGS .............................................. 122

6.4.10 SELECTION OF FILTERS AND THEIR HEAD LOSS .......................... 123

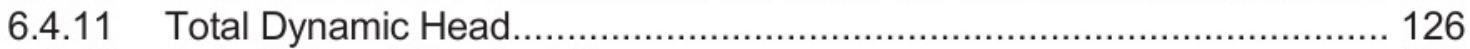

6.4.12 Calculation of Required Horsepower .............................................. 127

6.4.13 Selection of Pump and Motor ............................................................. 128

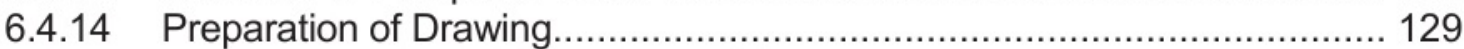

6.4.15 Preparation of Bill of Quantities BOQ .............................................. 129

6.5 DRIP DESIGN PROCEDURE-STEP BY STEP (ROW CROP) ................. 151

6.6 Selection and Design of Lateral Line ............................................... 166

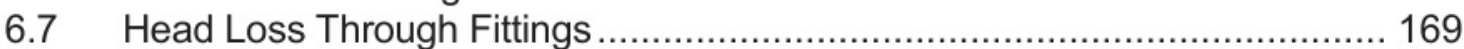

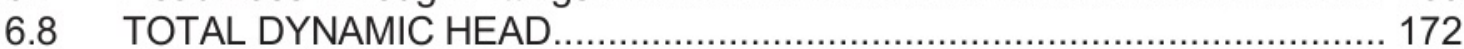

6.9 DESIGN OF DRIP IRRIGATION SYSTEM (ROW CROP) ....................... 177

6.10 DESIGN OF SPRINKLER IRRIGATION SYSTEM ...................................... 194

6.10.1 Components of Sprinkler System .............................................. 199

6.11 SPRINKLER SYSTEM TECHNICAL ASPECT ..................................... 200

6.12 Design Process Sprinkler..................................................................... 218

6.12.1 Factors Affecting the Layout of Sprinkler System ................................. 218

6.12.2 Design Procedure-Step by Step (Sprinkler) ....................................... 219

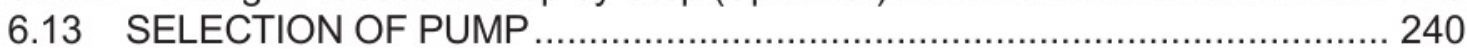

6.14 Design of Sprinkler Irrigation System - Example 2 .................................. 241 


\section{BASICS OF HEIS DESIGN}

The basic information required for design of micro irrigation system is described in following sections.

\subsection{GENERAL INFORMATION}

\subsubsection{Water Source}

It is very essential to confirm the source and quantum of water available before designing of any irrigation system. There are mainly three types of water sources used for irrigation in Pakistan namely Canal water, Tube wells and Dug wells. The location of the water source on the layout map should be demarcated which ultimately helps to locate the best possible location for head unit installation.

Using different methods as given below, the volume of available water can be determined for three types of available water sources.

\subsubsection{Canal Water}

Volume of water available can be calculated as under:

\begin{tabular}{ccl} 
& $\mathbf{V}$ & \multicolumn{1}{c}{$(\mathbf{B} \times \mathbf{C} \times \mathbf{K})$} \\
$\mathrm{V}$ & $=$ & Volume of water available (litres) \\
$\mathrm{B}$ & $=$ & Time of water availability (hrs) \\
$\mathrm{C}$ & $=$ & Discharge of canal outlet (LPS) \\
$\mathrm{K}$ & $=$ & Constant, 3600
\end{tabular}

Example: Determine volume of available water for $1.5 \mathrm{cfs}$ (42.5 Ips) canal outlet discharge. Total time of water availability is $\mathbf{5}$ hours.

$\mathrm{B}=5 \mathrm{hrs}$

$\mathrm{C}=\mathbf{4 2 . 5}$ Ips

Volume of available water $=(5 \times 42.5 \times 3600)=765450$ liters $\left(765.450 \mathrm{M}^{3}\right)$

If the discharge of the canal outlet is not known, then rough estimation can be made using the float method.

\subsubsection{2 $\quad \underline{\text { Tubewell Water }}$}

The discharge of the tubewell water can be estimated by the trajectory method as follows:

The Discharge in LPS can be found as

Project - Implementation Supervision Consultants (PSC) 


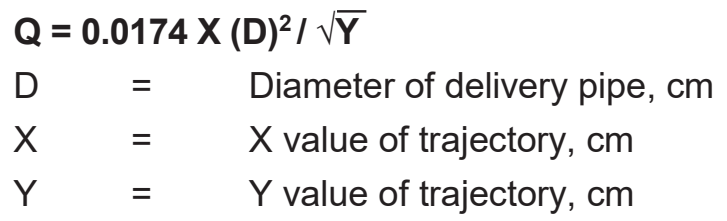

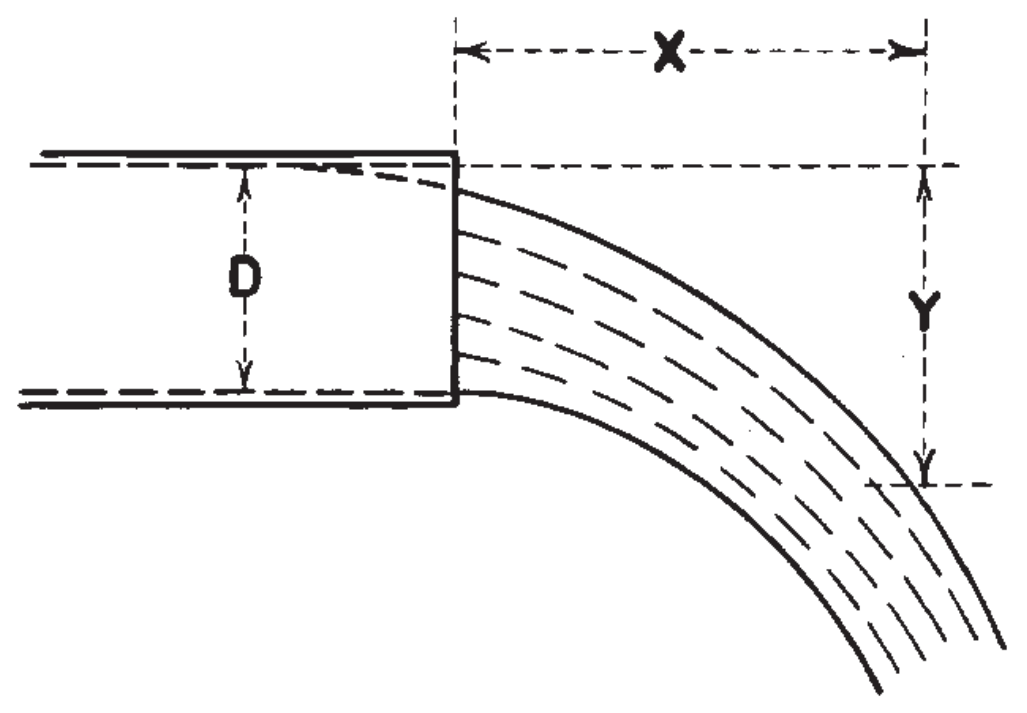

Fig. 5.1 Trajectory of Water Flow from the Tubewell

\section{Example:}

Determine the discharge of a tubewell with pipe diameter $11 \mathrm{~cm}, X \& Y$ values of trajectory are $55 \mathrm{~cm} \mathrm{\&} 25 \mathrm{~cm}$, respectively

Solution:

By using equation 3.5 the discharge of tubewell can be calculated as:

$$
\begin{aligned}
& Q=0.0174 X(D)^{2} T \sqrt{ } Y \\
& \mathrm{Q}=0.0174 \times(11)^{2} \times 55 / \sqrt{25} \\
& =\quad 23.2 \mathrm{LPS}
\end{aligned}
$$

\subsubsection{Dug Well}

The volume of water in a dugwell can be determined using following relationship.

Available volume of water in $\mathrm{m}^{3}$ can be found as:

$$
\mathrm{V} \quad=\quad 3.14(\mathrm{D})^{2}(\mathrm{~B}) / 4
$$


$\mathrm{V} \quad=\quad$ Volume of water, $\mathrm{m} 3$

$\mathrm{D}=$ Diameter of Well, $\mathrm{m}$

$\mathrm{B}=$ Depth of water column, $\mathrm{m}$

\section{Example:}

Calculate water availability for 5 meter diameter dug well, the depth of water column in the dug well is $2 \mathrm{~m}$.

Using equation 3.4, volume of available water in the dug well can be calculated as:
$\mathrm{V} \quad=$
$3.14 \times(5 \times 5) \times 2 / 4$
$=$
$39.25 \mathrm{~m}^{3}$

\subsection{FIELD LAYOUT AND TOPOGRAPHY}

The first step to proceed for the design is to determine the area of the field layout for which the system is to be designed. This may be done measuring directly the lengths and the widths of the field. A particular farmer field will be of specific geometrical shape such as square and rectangular. Sometimes it may be of irregular shape. Measurements for such area will not be easy with conventional systems using measuring tapes; it may require use of Global Positioning System (GPS) for establishing plot boundaries and directly measuring the area. Particular geometrical shapes and formulae for calculating area are given below:

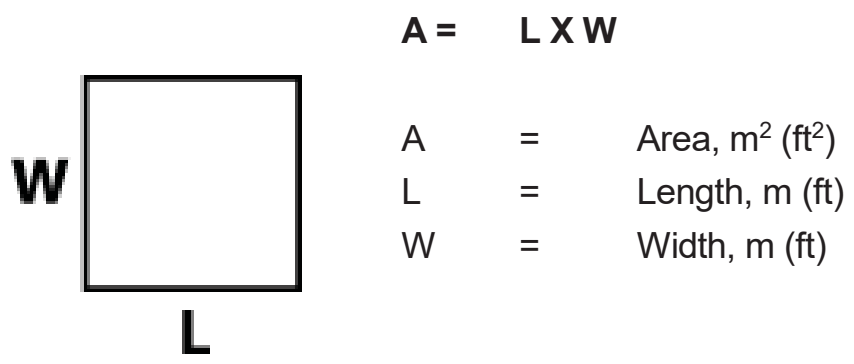

$\mathrm{L}_{2}$

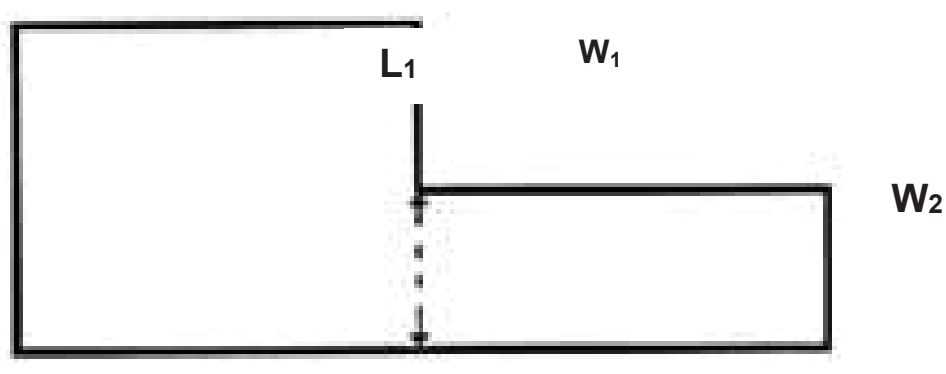

$A=\quad\left(L_{1} \times W_{1}\right)+\left(L_{2} \times W_{2}\right)$

Where;

$\mathrm{L} 1, \mathrm{~L} 2 \quad$ = Length, $\mathrm{m}(\mathrm{ft})$

$\mathrm{W} 1, \mathrm{~W} 2 \quad=\quad$ Width, $\mathrm{m}(\mathrm{ft})$ 


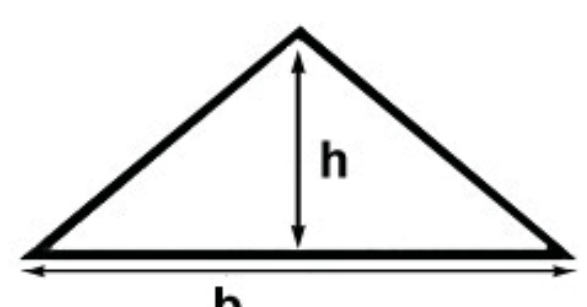

b

$A=1 / 2 \times b \times h$

$$
\begin{array}{rll}
\mathrm{A} & = & \text { Area, } \mathrm{m}^{2}\left(\mathrm{ft}^{2}\right) \\
\mathrm{b} & = & \text { Width, } \mathrm{m}(\mathrm{ft}) \\
\mathrm{h} & = & \text { Height of triangle, } \mathrm{m}(\mathrm{ft})
\end{array}
$$

In case the area to be irrigated is fairly large and visibly having topography uneven, a topographic survey of the area is carried out in order to determine the general slope and contours are drawn. If practically possible, the main line is laid along contours and sub-mains are laid along the slope. Accordingly, a field layout is drawn showing the dimensions (length and width) of the area, location of water source/pump-set, location and lengths of main, sub-mains, laterals according to the plant or row spacing

\subsection{CROPS}

Information regarding crops should be entered in "crop information" section of the design

\begin{tabular}{|c|c|c|c|c|c|c|c|c|c|}
\hline \multicolumn{3}{|c|}{ Parameters } & \multirow[t]{2}{*}{ Crop } & \multirow{2}{*}{$\begin{array}{c}\text { Area } \\
\text { (acres) }\end{array}$} & \multirow{2}{*}{$\begin{array}{c}\text { Plant } \\
\text { spacing } \\
\text { (m) }\end{array}$} & \multirow{2}{*}{$\begin{array}{c}\text { Row } \\
\text { spacing } \\
\text { (m) }\end{array}$} & \multirow{2}{*}{$\begin{array}{c}\text { Age of } \\
\text { crop } \\
\text { (years) }\end{array}$} & \multirow[t]{2}{*}{$\begin{array}{c}\text { Sowing } \\
\text { Date }\end{array}$} & \multirow{2}{*}{$\begin{array}{c}\text { Harvesting } \\
\text { Date }\end{array}$} \\
\hline \multirow{2}{*}{ Block-I } & \multirow{2}{*}{ Row crops } & Proposed & & & & & & & \\
\hline & & Rotation & & & & & & & \\
\hline \multicolumn{3}{|c|}{ Sub-Total: I } & & & & & & & \\
\hline \multirow{2}{*}{ Block-II } & \multirow{2}{*}{ Orchards } & Type-I & & & & & & & \\
\hline & & Type-II & & & & & & & \\
\hline \multicolumn{3}{|c|}{ Sub-Total: II } & & & & & & & \\
\hline Block-III & \multicolumn{2}{|c|}{ Annual Crops } & & & & & & & \\
\hline \multicolumn{3}{|c|}{ Sub-Total: III } & & & & & & & \\
\hline \multirow{2}{*}{ Block-IV } & \multirow{2}{*}{ Field Crops } & Type-I & & & & & & & \\
\hline & & Type-II & & & & & & & \\
\hline \multicolumn{3}{|c|}{ Sub-Total: IV } & & & & & & & \\
\hline \multicolumn{3}{|c|}{ Total / Design Value } & & & & & & & \\
\hline
\end{tabular}
proforma as given in Table 5.1

Table 5.1 Crop Information Proforma 


\subsubsection{Row Crops}

Line source drip systems are generally suitable for row crops such as cotton, maize, cucumber, chilli, capsicum, melons, tomatoes, onions, sunflower and sugarcane etc. Sprinklers can also be used on most of these crops with certain care. Generally distance between two plant rows is kept $0.76 \mathrm{~m}(2.5 \mathrm{ft}$ ) under conventional planting practice (Furrow), whereas under drip irrigation system it will cost more. An appropriate technique may be to

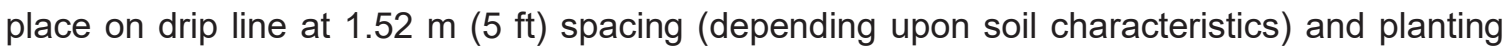
two plant rows on each side of the lateral. A single drip line may be provided for two or more crop rows or for a single crop row depending upon growth behavior. The information needed for designing a system includes distance between rows of crop and the time of sowing and harvesting etc. Similar information regarding rotational crop is very important for selecting and designing a suitable system that will be suitable for both the crops.

\subsubsection{Orchards}

Orchards comprise of fruits or nut producing trees grown for commercial production. Point source drip line, mini sprinklers, spray jets or bubblers can be used for irrigation of orchard depending upon plant stage. Most of the orchard crops grown in Pakistan include Banana, Coconut, Guava, Mango, Citrus, Date Palm, Lychee, Apple, Apricot, Chikku, Ber, Peach and Plum. The information regarding time of sowing, age of crop, canopy diameter and spacing between plants and rows of matured/new orchard is required to be collected for designing purpose. It is also important to note whether farmer plans to go for intercultural practices in the orchard or not. This should be decided at the planning stage and will effect the selection of particular emitting devices/high efficiency irrigation system.

\subsubsection{Annual Crops}

This category particularly covers sugarcane which remains standing for whole of the year.

\subsubsection{Field Crops}

It comprises a particular group of crops which are not cultivated in geometrical shapes (beds, furrow) but are broadcasted like wheat, fodders, oilseeds etc. sprinkler system is suited for such kind of crops.

\section{$5.4 \quad$ IRRIGATION SYSTEM EFFICIENCY}

Irrigation system efficiency is that part of the water pumped or diverted through the conveyance system which is used effectively by the plants. It is the product of two types of efficiencies i.e., conveyance efficiency and field application efficiency. Conveyance efficiency represents the efficiency of water transported in canals, watercourses and field application efficiency represents the efficiency of water application in the field. For pressurized irrigation systems, conveyance efficiency is almost $100 \%$ and thus design engineers are only concerned with field application efficiency. Conventional irrigation system is the lowest efficient method. Among pressurized irrigation systems, drip is the most efficient irrigation method as shown in Fig. $\mathbf{5 . 2}$ 


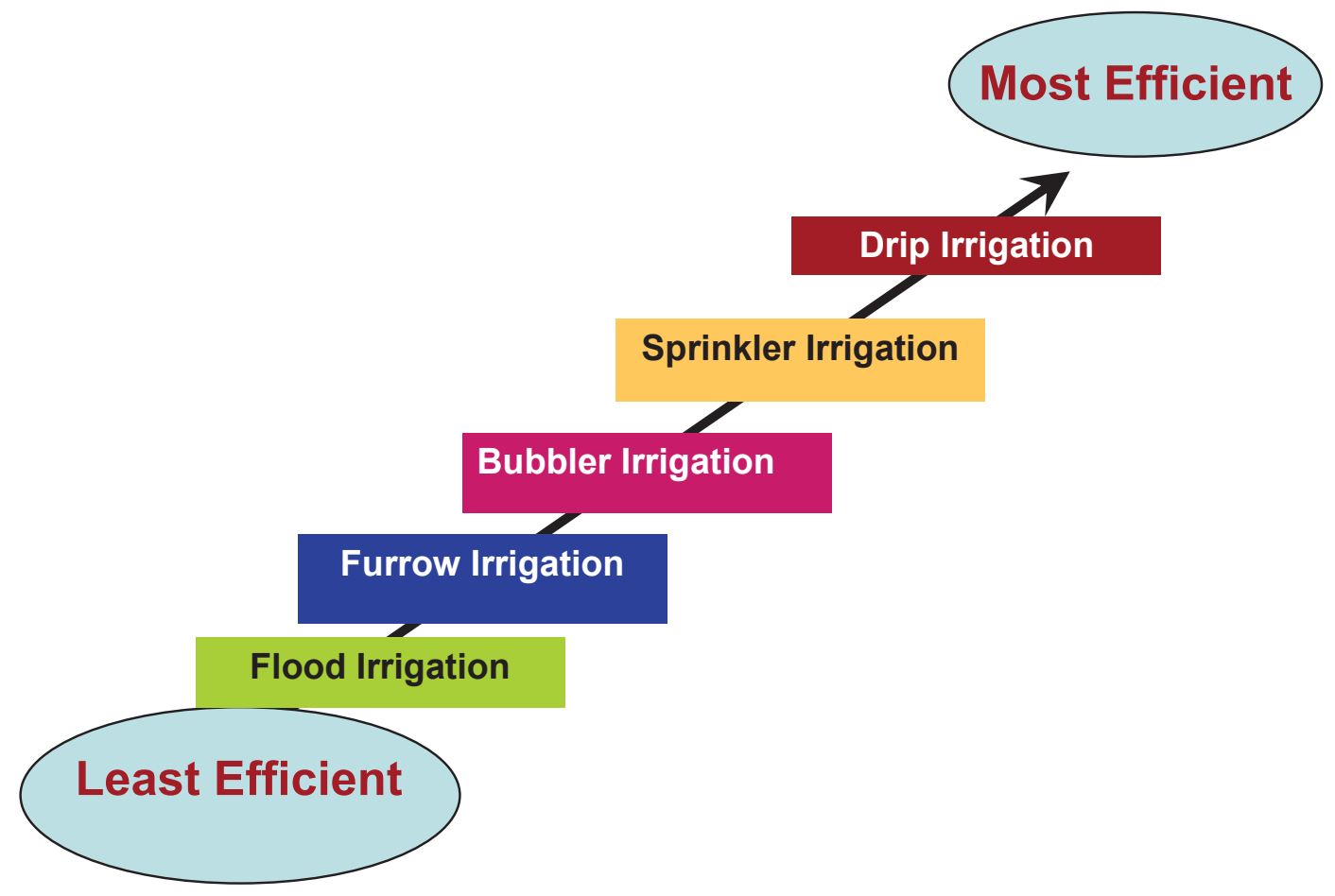

Fig. 5.2 Least to Most Efficient Irrigation Systems

Field application efficiency mainly depends on the irrigation method and the level of farmer discipline. Some indicative values of the average field application efficiency are given in following Table 3.4 .

Table 5.2 Values of Field Application Efficiency

Water Application Method

\begin{tabular}{ll}
\hline Surface & $40-70$ \\
Sprinkler (Center Pivot) & $85-90$ \\
Sprinkler (Linear Move) & $80-88$ \\
Fixed Sprinkler (Solid set) & $60-85$ \\
Trickle/ Drip (Point Source) & $65-92$ \\
\hline Trickle/ Drip (Line Source) & $60-85$ \\
\hline
\end{tabular}

\subsection{WATER QUALITY}

Quality of water is very important for prevention of clogging in micro irrigation system especially for drip irrigation system. Potential contributors towards emitter clogging are shown in Table 5.3 
Table 5.3 Major Contributors of Emitter Clogging

\begin{tabular}{|c|c|c|}
\hline $\begin{array}{l}\text { PHYSICAL } \\
\text { (Suspended } \\
\text { Solids) }\end{array}$ & $\begin{array}{l}\text { CHEMICAL } \\
\text { (Precipitation) }\end{array}$ & $\begin{array}{c}\text { BIOLOGICAL } \\
\text { (Bacteria and algae) }\end{array}$ \\
\hline 1. Sand & 1. Calcium or magnesium carbonate & 1. Filaments \\
\hline 2. Silt & 2. Calcium sulphate & 2. Slimes \\
\hline \multirow[t]{4}{*}{ 3. Clay } & \multirow[t]{4}{*}{$\begin{array}{l}\text { 3. Heavy metal hydroxides, oxides, carbonates, silicates } \\
\text { and sulphides }\end{array}$} & $\begin{array}{ll}3 . & \text { Microbial } \\
\text { depositions: } & \end{array}$ \\
\hline & & (a) Iron \\
\hline & & (b) Sulphur \\
\hline & & (c) Manganese \\
\hline \multirow[t]{7}{*}{ 4. Organic matter } & 4. Fertilizers & \multirow[t]{4}{*}{ 4.Bacteria } \\
\hline & (a) Phosphate & \\
\hline & (b) Aqueous ammonia & \\
\hline & \multirow[t]{4}{*}{ (c) Iron, zinc, copper, manganese } & \\
\hline & & $\begin{array}{l}\text { 5.Small aquatic } \\
\text { organisms }\end{array}$ \\
\hline & & (a) Snail eggs \\
\hline & & (b) Larva \\
\hline
\end{tabular}

(Source: FAO, 1994)

Prevention requires an understanding of the potential problems associated with a particular water source. Water quality information should be obtained and made available to the designer and irrigation manager in the early stages of the planning so that suitable system components especially the filtration system and management and maintenance plans can be selected. Water quality refers to the characteristics of a water supply that will influence its suitability for a specific use, i.e. how well the quality meets the needs of the user. Quality is defined by certain physical, chemical and biological characteristics (FAO) and may impose long term impacts on soil as well as result in clogging of micro irrigation system. Type and quantity of dissolved salts will determine the severity of water quality. Standard water quality tests are shown in Table $\mathbf{5 . 4 .}$

Table 5.4 Standard quality tests for Micro Irrigation System

\begin{tabular}{|l|l|}
\hline Major Inorganic Salts & Micro-organisms \\
\hline Hardness $^{1}$ & Iron \\
\hline Suspended Solids & Dissolved Oxygen \\
\hline Total Dissolved Solids (TDS) 1 & Hydrogen Sulphide \\
\hline BOD (Biological Oxygen Demand) & Iron Bacteria \\
\hline COD (Chemical Oxygen Demand) & Sulphate Reducing Bacteria \\
\hline Organics and Organic Matter & \\
\hline
\end{tabular}

(Source: FAO, 1994) 
The analysis needed will vary with each situation. It is to keep in mind that cost of the micro irrigation system is very high and it is advisable to bear some additional cost which is very nominal to perform these tests so as the system can be run effectively. The presence of elements (Table 5.6) in irrigation water will determine the degree of clogging and restriction of water use.

Table 5.6 Influence of water quality on emitter clogging

\begin{tabular}{|c|c|c|c|c|}
\hline \multirow{2}{*}{ Potential Problem } & \multirow{2}{*}{ Units } & \multicolumn{3}{|c|}{ Degree of Restriction on Use } \\
\hline & & None & Slight to Moderate & Severe \\
\hline \multicolumn{5}{|l|}{ Physical } \\
\hline Suspended Solids & $\mathrm{mg} / \mathrm{l}$ & $<50$ & $50-100$ & $>100$ \\
\hline \multicolumn{5}{|l|}{ Chemical } \\
\hline $\mathrm{pH}$ & & $<7.0$ & $7.0-8.0$ & $>8.0$ \\
\hline Dissolved Solids & $\mathrm{mg} / \mathrm{l}$ & $<500$ & $500-2000$ & $>2000$ \\
\hline Manganese2 & $\mathrm{mg} / \mathrm{l}$ & $<0.1$ & $0.1-1.5$ & $>1.5$ \\
\hline Iron3 & $\mathrm{mg} / \mathrm{l}$ & $<0.1$ & $0.1-1.5$ & $>1.5$ \\
\hline Hydrogen Sulphide & $\mathrm{mg} / \mathrm{l}$ & $<0.5$ & $0.5-2.0$ & $>2.0$ \\
\hline \multicolumn{5}{|l|}{ Biological } \\
\hline Bacterial populations & $\begin{array}{l}\text { maximum } \\
\text { number/ml }\end{array}$ & $<10000$ & $10000-50000$ & $>50000$ \\
\hline
\end{tabular}

(Source: FAO, 1994)

\subsection{LEACHING REQUIREMENT}

Presence of salts in irrigation water and in the soil affects the crop yield. Under micro irrigation system, salts are usually repelled away from the wetting front of the emitter; therefore, marginally saline water can be used efficiently for crop production. For sprinkler irrigation system, irrigation frequency may be more than one day especially under rain-guns; there is a need to account for leaching requirements to leach the salts down from root zone of the plant. It is important to keep the salinity level within permissible limits by applying additional quantity of water to soil/plants so that yield may not be reduced more than $10 \%$.

Leaching requirement (LR) can be estimated using following equation (Rhoades and Merrill 1976):

$$
L R=\frac{E C_{w}}{5\left(E C_{e}\right)-E C_{w}}
$$

LR =

minimum leaching requirement

(Fraction) needed to control salts within the tolerance (ECe)

$\mathrm{EC}_{\mathrm{w}}=$ salinity of the applied irrigation water in $\mathrm{dS} / \mathrm{m} \quad$ which can be determined by laboratory analysis

$\mathrm{EC}_{\mathrm{e}}=$ Average soil salinity tolerated by the crop as measured on a soil saturation extract which is depicted in Table $\mathbf{5 . 7}$ 
Table $5.7 \quad$ Values of ECe with $10 \%$ yield reduction

\begin{tabular}{|l|c|}
\hline \multicolumn{1}{c|}{ Crop } & EC $_{\mathrm{e} \text { dS/m }}$ \\
\hline Cotton & 9.6 \\
\hline Sorghum & 5.1 \\
\hline Wheat & 7.4 \\
\hline Corn (maize) & 2.5 \\
\hline Tomato & 3.5 \\
\hline Cucumber & 3.3 \\
\hline Spinach & 3.3 \\
\hline Potato & 2.5 \\
\hline Onion & 1.8 \\
\hline Date palm & 6.8 \\
\hline Orange & 2.3 \\
\hline Apple & 2.3 \\
\hline Peach & 2.2 \\
\hline Apricot & 2.0 \\
\hline Grape & 2.5 \\
\hline Almond & 2.0 \\
\hline
\end{tabular}

Example: Calculate Leaching Requirement for sprinkler system

Given data:

Crop: Wheat

ECw: $2.1 \mathrm{dS} / \mathrm{m}$

Solution: Select ECe of wheat from Table 3.8. ECe = 7.4 and solving equation 3.8.

$$
\begin{aligned}
& L R=\frac{E C_{w}}{5\left(E C_{e}\right)-E C_{w}} \\
& L R=2.1 /(5 \times 7.4-2.1)=0.06 \text { (fraction) }
\end{aligned}
$$

\subsection{WETTED AREA}

Wetted area is important for micro irrigation system as only portion of the plant's area is wetted as shown in Fig. 5.2. The first criterion, wetting a sufficient portion of the plant's root volume, must be achieved for a plant to efficiently utilize the water that is delivered.

When drip devices are used, the area or volume of the soil that is wetted depends on the soil type and emitter flow rate. At least 33 percent and up to 67 percent of the plant root zone should be wetted to get the maximum benefit from micro-irrigation. On sandy soils, microspray or sprinkler emitters rather than drip emitters may be needed to wet sufficient root volume. 


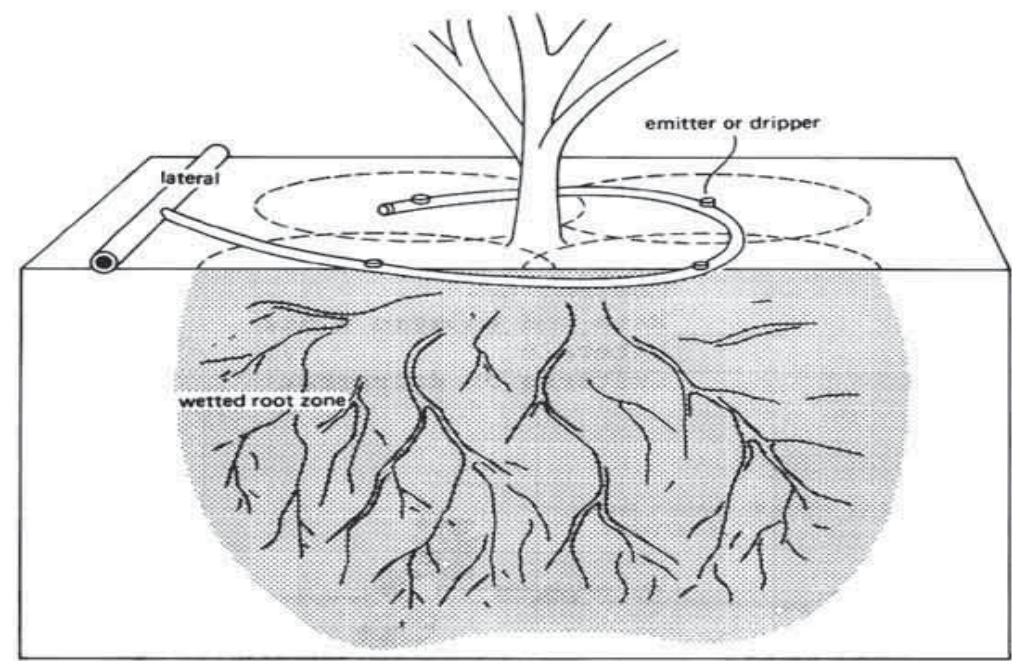

Fig. 5.2 Partial wetting of soil under micro irrigation system (Source: FAO,)

While published guidelines for drip emitter wetted diameters on typical sand, loam and clay soils can be used, it is much better to field test by actually wetting one or more selected typical locations in the field. This can be done easily by setting up a small portable pump (or connecting to a house or barn water system) and running a suitable line with drip emitters attached to the selected sites (adjust pressure according to emitters used). The wetting patterns which develop from dripping water onto the soil depend on discharge and soil type. Fig. $5.5 \& 5.6$ shows the effect of changes in discharge on two different soil types, namely sand and clay.

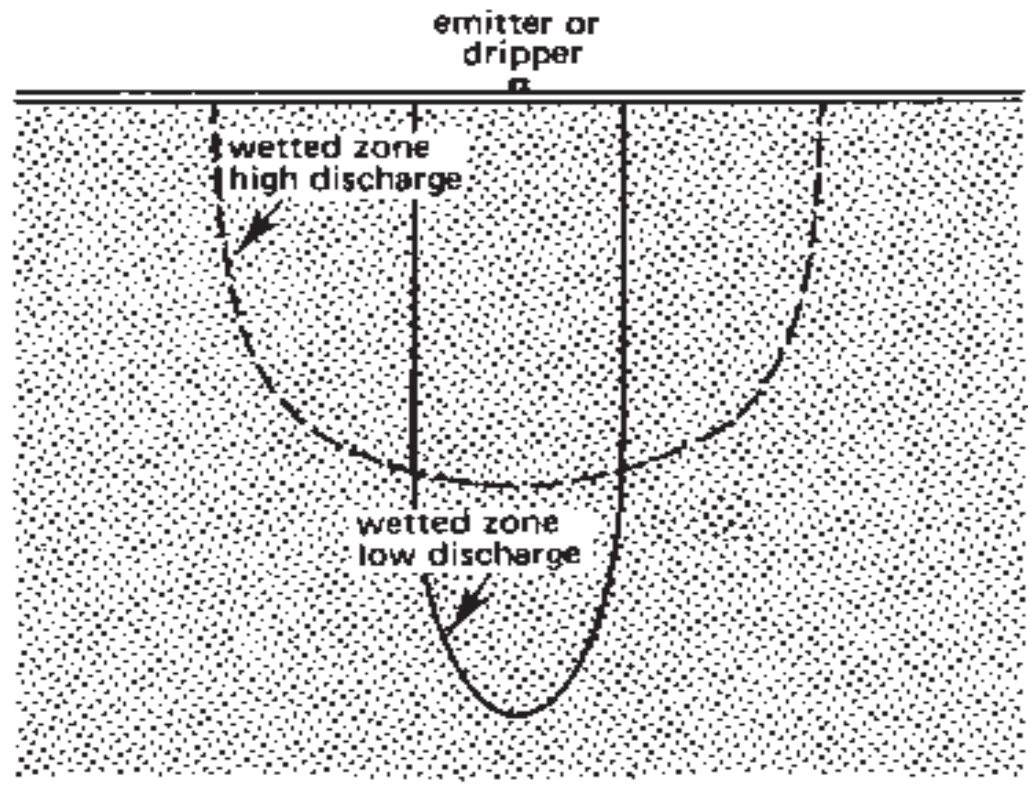

Fig. 5.3 Wetting patterns for Sandy soils with high and low discharge (Source: FAO,) 


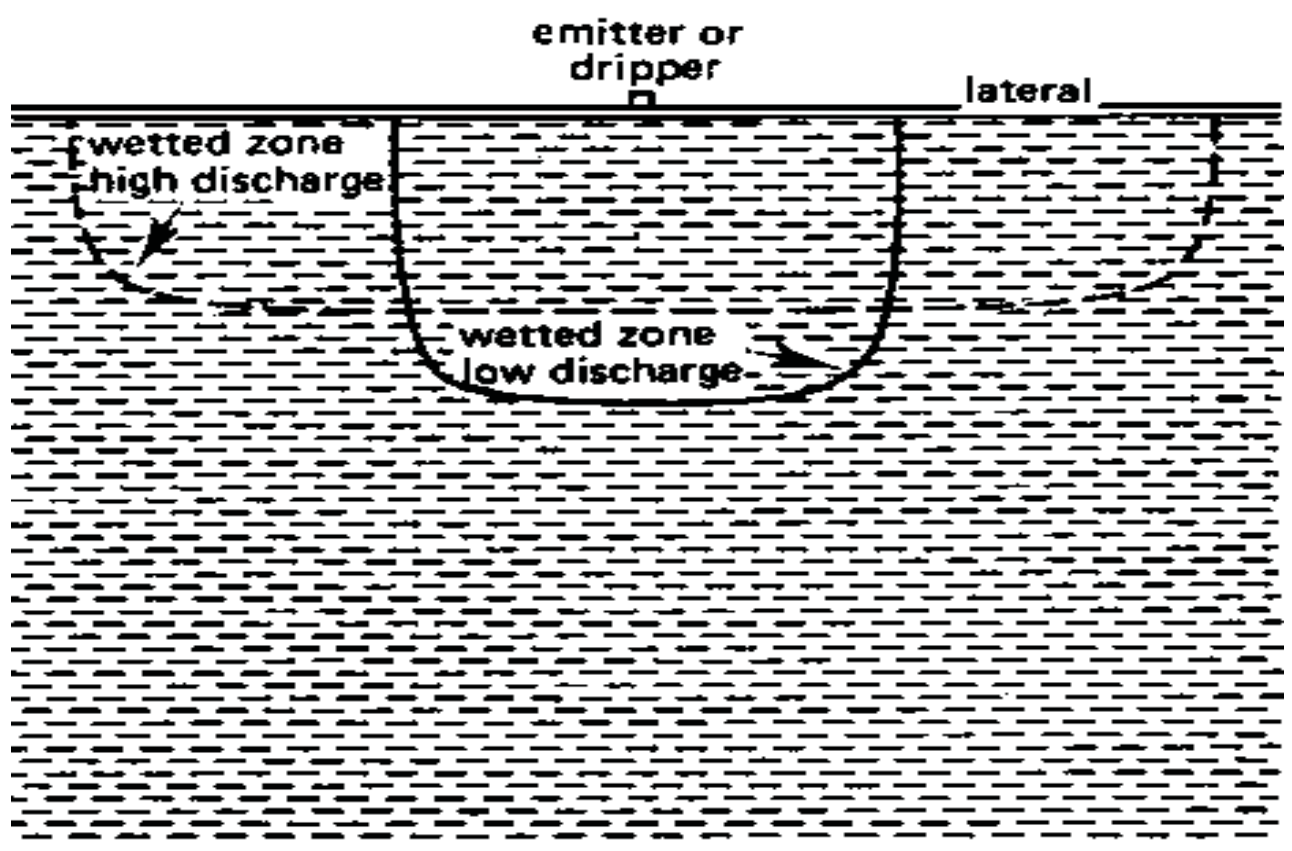

Fig. 5.4 Wetting patterns for Clay soils with high and low discharge rates

On sandy soils, the maximum wetted width may be reached in as little as two hours, but on clay soils this may take 12 to 15 hours (caution: do not allow surface runoff to occur). For safety, the emitter should be operated the same number of hours that is planned for the zone set time, according to soil type. Measurement of wetted diameter is done by trenching across the visible wetted edge to see how far from the emitter water has moved. The wetted area will be wider beneath the soil surface, but it is impossible to know how far it extends without digging. Estimated wetted area by 4LPH dripper is given in Table 5.7a.

Table 5.7a Estimated are wetted by $4 \mathrm{~L} / \mathrm{hr}$ emitter $(\mathrm{m} \times \mathrm{m})$

\begin{tabular}{|c|c|c|c|c|}
\hline \multirow{3}{*}{ Soil depth $(\mathrm{m})$} & \multirow{3}{*}{ Soil Texture } & \multicolumn{3}{|c|}{ Degree of soil stratification } \\
\cline { 3 - 5 } & & Homogeneous & Stratified & Layered \\
\hline \multirow{3}{*}{0.75} & Coarse & $0.4 \times 0.5$ & $0.6 \times 0.8$ & $0.9 \times 1.1$ \\
\cline { 2 - 5 } & & & & $1.2 \times 1.5$ \\
\cline { 2 - 5 } & Medium & $0.7 \times 0.9$ & $1.0 \times 1.2$ & $1.5 \times 1.8$ \\
\cline { 2 - 5 } & Fine & $0.9 \times 1.1$ & $1.2 \times 1.5$ & $1.4 \times 1.8$ \\
\hline \multirow{3}{*}{1.5} & Coarse & $0.6 \times 0.8$ & $1.1 \times 1.4$ & $2.2 \times 2.7$ \\
\cline { 2 - 5 } & & & & $1.7 \times 2.1$ \\
\cline { 2 - 5 } & Medium & $1.0 \times 1.2$ & $1.6 \times 2.0$ & $2.0 \times 2.4$ \\
\cline { 2 - 5 } & Fine & $1.2 \times 1.5$ & & \\
\hline
\end{tabular}

(Source: Jack Keller and Ron D.Bliesner- 1990)

Table 5.8 can also be used if none of the information regarding wetted diameter or area of soil available. To be on safer side lower values may preferably to used. 
Table 5.8 Estimated area wetted

\begin{tabular}{|c|c|c|r|r|r|r|}
\hline \multirow{2}{*}{ Soil Type } & \multicolumn{3}{|c|}{ Diameter (m) } & \multicolumn{3}{c|}{ Area (m2) } \\
\cline { 2 - 7 } & Min & \multicolumn{1}{|c|}{ Max } & \multicolumn{1}{c|}{ Average } & \multicolumn{1}{c|}{ min } & \multicolumn{1}{c|}{ max } & \multicolumn{1}{c|}{ Average } \\
\hline Sandy (coarse soil) & 0.8 & 1.5 & 1.1 & 0.46 & 1.82 & 1.14 \\
\hline Loam (medium soil) & 1.5 & 2.7 & 2.1 & 1.82 & 5.91 & 3.87 \\
\hline Clay (fine soil) & 2.7 & 4.3 & 3.5 & 5.91 & 14.30 & 10.11 \\
\hline
\end{tabular}

\subsection{POWER SOURCE}

All sprinkler and drip irrigation systems require energy to move water through pipe distribution network and deliver it through the emitting devices. In some instances, this energy is provided by gravity as water flows downhill through the delivery system which is most likely possible in Balochistan, NWFP and Northern areas of Pakistan. However, in most irrigation systems, energy is provided by a pump that in turn receives its energy from either an electric motor or an internal combustion engine. The combination of pump and engine is central to the performance of most irrigation systems. The most common power source/drive units for pumps are electric motors, diesel or petrol engines and PTO of tractors.

\subsubsection{Electric Motors}

Electric motors are more efficient, cheaper to maintain and where they needed to be run continuously, the fuel costs are lower than for other types of power source. On drip irrigation system, mostly Three Phase Motors are installed. Before designing a system, a transformer of required capacity must be ensured to operate the system. The electricity supply in Pakistan is 50 cycles and the standard motor operating speeds are $2900 \mathrm{rpm}, 1450 \mathrm{rpm}$ and $960 \mathrm{rpm}$. Ideally the pump unit should couple direct to the motor shaft so the speeds of the two units are identical. However, where a different pump speed is required, V-belts and pulleys will be required. Efforts should be made to select an efficient electric motor to keep the operational cost low.

\subsubsection{Petrol Engines}

Petrol engines can be used for intermittent operation such as supplementary irrigation, where the operating time per day does not exceed two or three hours. The use of CNG fuel is becoming more widespread in Pakistan which can be a good replacement of petrol to be used.

\subsubsection{Diesel Engines}

Compact high speed diesel engines should be used as energy source where electricity is not available. Diesel engines offer the most efficient form of drive for 
pumps. They are particularly suited for use on portable installations. Care should be taken to select a suitable drive unit otherwise operational cost will become much higher as compared to the electricity.

\subsubsection{Tractors}

Tractor can also be used as power source for high pressure system such as Rain Gun sprinkler system which requires high energy or to drive pumps as a stand-by measure in the event of the primary unit breaking down or where the scheme is primarily for supplementary irrigation and is only operated for a few hours every day. 


\section{DRIP DESIGN STEPS}

The main objective of an irrigation system design is to supply adequate and timely water to plants and to help farmer to get best out of his fields. The following considerations may help achieve this objective:

1. Planning proper irrigation zones and system layout

2. Properly engineered system components

Properly engineered system components are secondary to a good system layout and it has a little value if the system has not been properly zoned and planned. It may include the following objectives:

- Optimum selection of the system components

- Ease in operation and maintenance of the system

- Low system cost with high efficiency

\subsection{OBJECTIVE OF DESIGN}

- Selection of Optimum Components

- Easy Management and Maintenance of System Parts

- Low System Cost Vs High Efficiency

- To help farmer get best out of his field

- To maintain higher system and irrigation efficiency by means of higher emission uniformity.

- To maintain optimum moisture level in soil for optimization of crop yield.

- To maintain both initial investment and annual cost at minimum level.

- To design suitable type of system which last and perform well.

- To design a manageable system which can be easily operated and maintained.

- To satisfy and fulfill the requirements of crops and farmers.

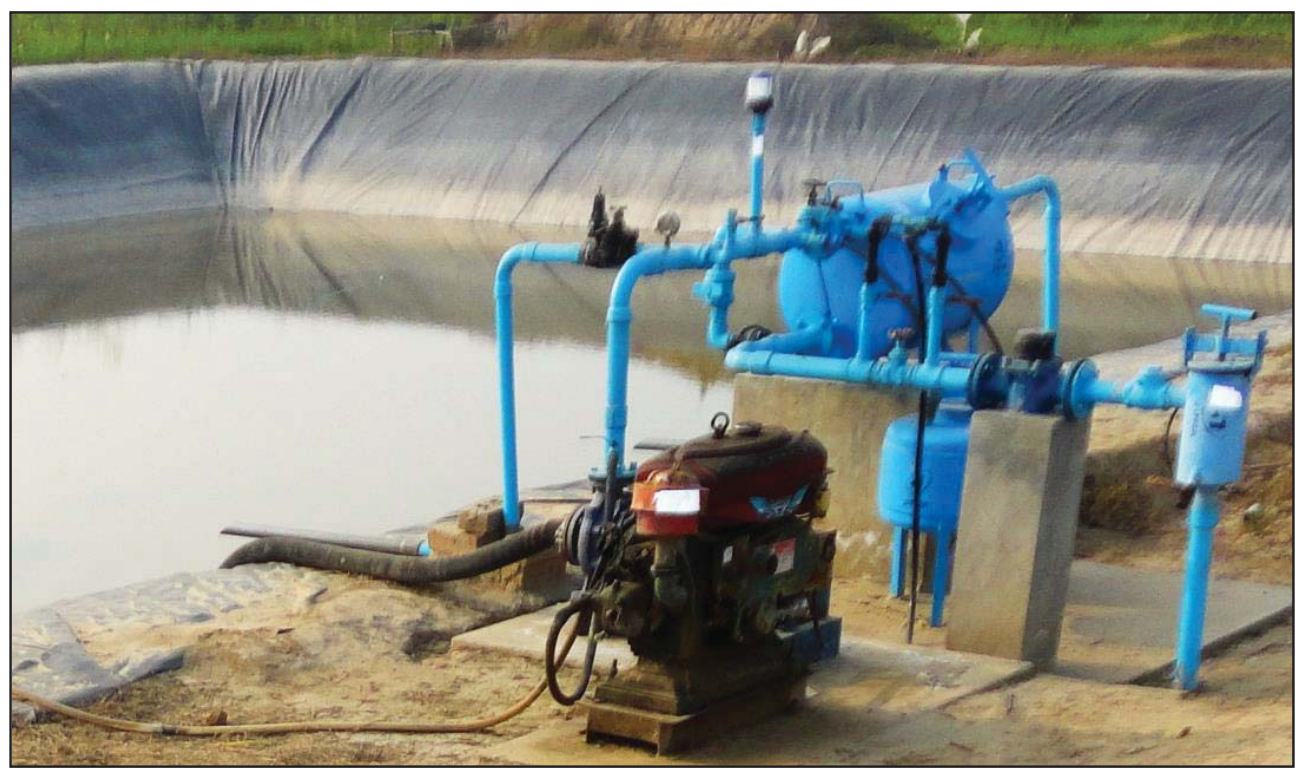




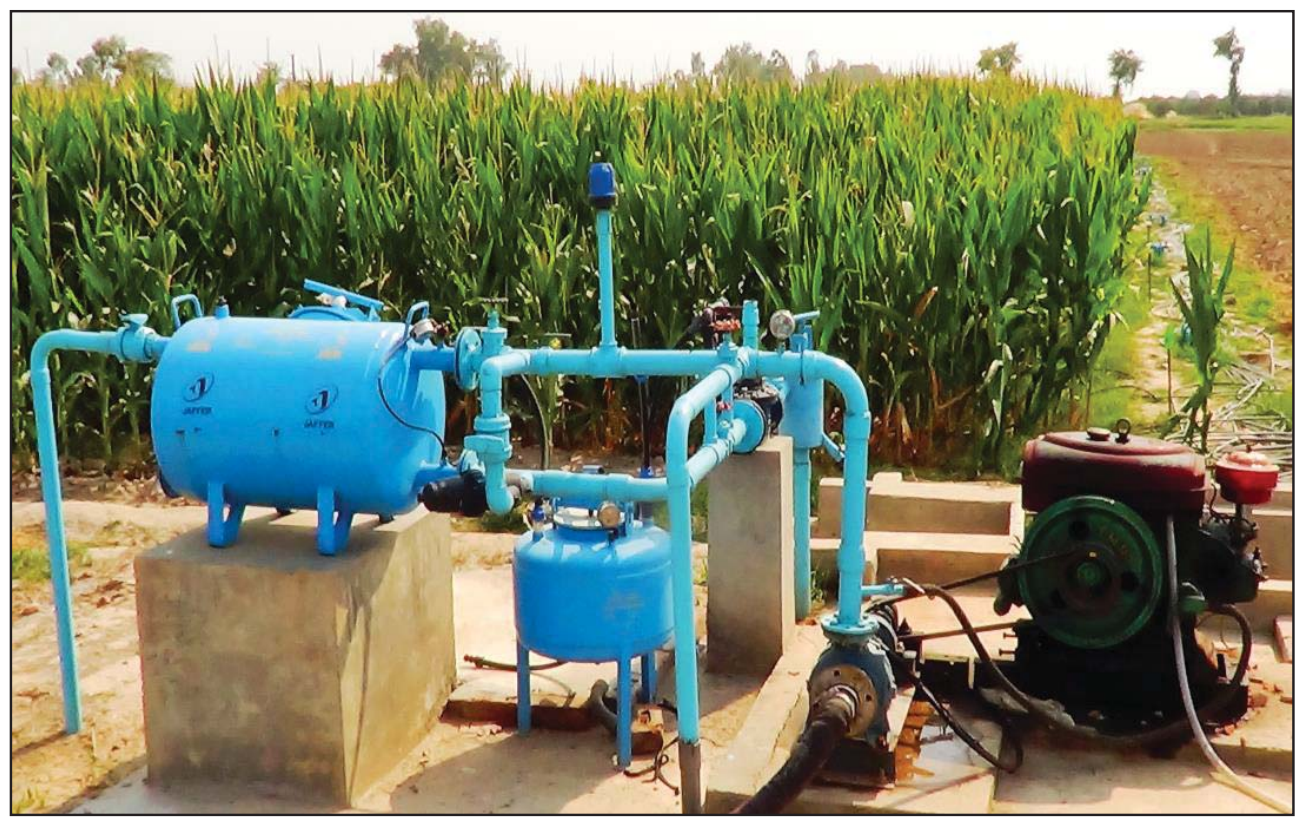

\subsection{DRIP DESIGN PROCEDURE-STEP BY STEP (ORCHARD)}

Under the on-going project, drip systems are being installed on orchard and at row crops/vegetables. In this section, steps for designing a drip system for orchard will be discussed. The following are the design steps.

1. Collection of Basic Information

2. Estimation of Peak Water Requirement PWR

3. Drawing of project area, selection of zone area and No. of Operations

4. Selection of emitter/dripper, and flow rat

5. No. of emitters per plant, No. of drip lines per row, optimal distance between two laterals

6. Calculation of plant area, total number of plants and minimum number of emitters per plant

7. Calculation of total length of lateral and total No. of emitters

8. Calculation of Total Flow rate requirement $(\mathrm{Q})$

9. Calculation of Application Rate

10. Total Operational Time

11. Pipe Hydraulics

12. Selection and Design of Lateral Line

13. Design of Sub-mainline

14. Design of Mainline

15. Selection of Filters and other equipment and head loss

16. Calculation of total dynamic head $(H)$

17. Calculation of required horsepower (HP)

18. Selection of Pumps and Motor

19. Preparation of Drawing

20. Preparation of Bill of Quantities 


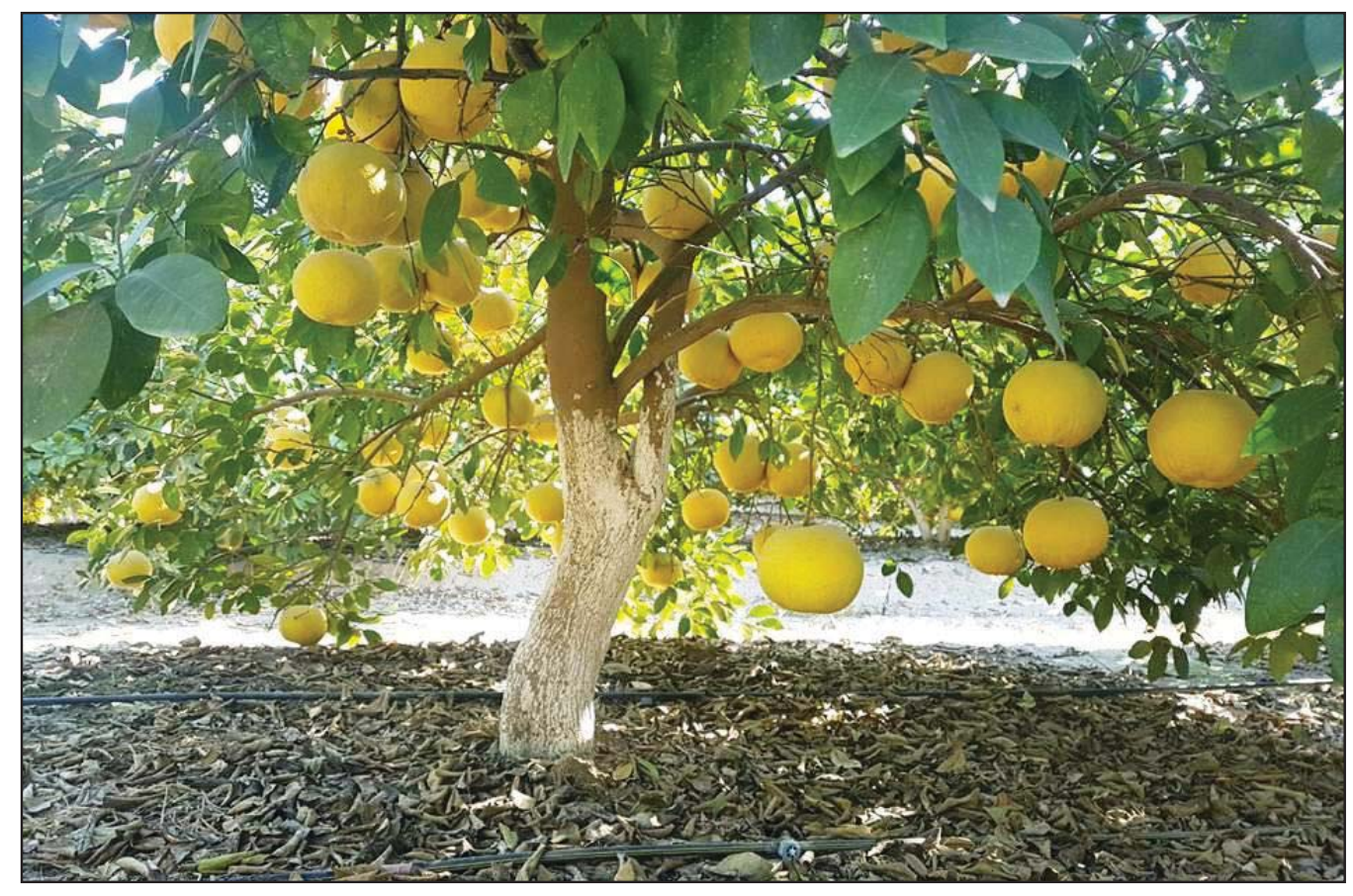

Step 1. Collection of Basic Information

The following basic information be available before designing a drip irrigation system.

- General information: Name of farmer, village/chak No., tehsil, district, phone No.

- Land holding and Area spared for the project

- Engineering survey: GPS coordinates, Field measurement, Elevation difference/slope. After field measurement, a map showing all dimensions and location of water source be drawn

- Agricultural details: crops (orchard, row/field crop), spacing, type, age, reference evapotranspiration of the area and water requirement of crop

- Crop Spacing (Row to Row, Plant to Plant), sowing and harvesting date

- Soil Type/texture

- Soil and water analysis reports: water quality, presence of iron, pH, suspended particles, soil type, Ec, pH

- Water Source, quantity, availability, location

- Power Source:Electric motor, diesel engine, tractor, solar system

- Climatologically data: temperature, humidity, rainfall, wind speed

- Peak Water Requirement: (ETo, Kc, Cf)

- Water source and Total Available Time of water

- System capacity: The system should have capacity adequate to fulfill daily crop water requirements of the area within a stipulated time or not more than 12 hours of operation per day (only for Pakistan circumferences, otherwise may be $22 \mathrm{hrs})$.

The basic information can be categorized as under. 


\subsubsection{General Information}

\begin{tabular}{|l|l|l|l|}
\hline Name of beneficiary & Town/Village/City & \\
\hline Tehsil & & District & \\
\hline Province & & Phone No. & \\
\hline Land holding (Acre) & & Scheme area (acres) & \\
\hline $\begin{array}{l}\text { Topography } \\
\text { (Flat/Undulated) }\end{array}$ & & & \\
\hline
\end{tabular}

\subsubsection{Crop Information}

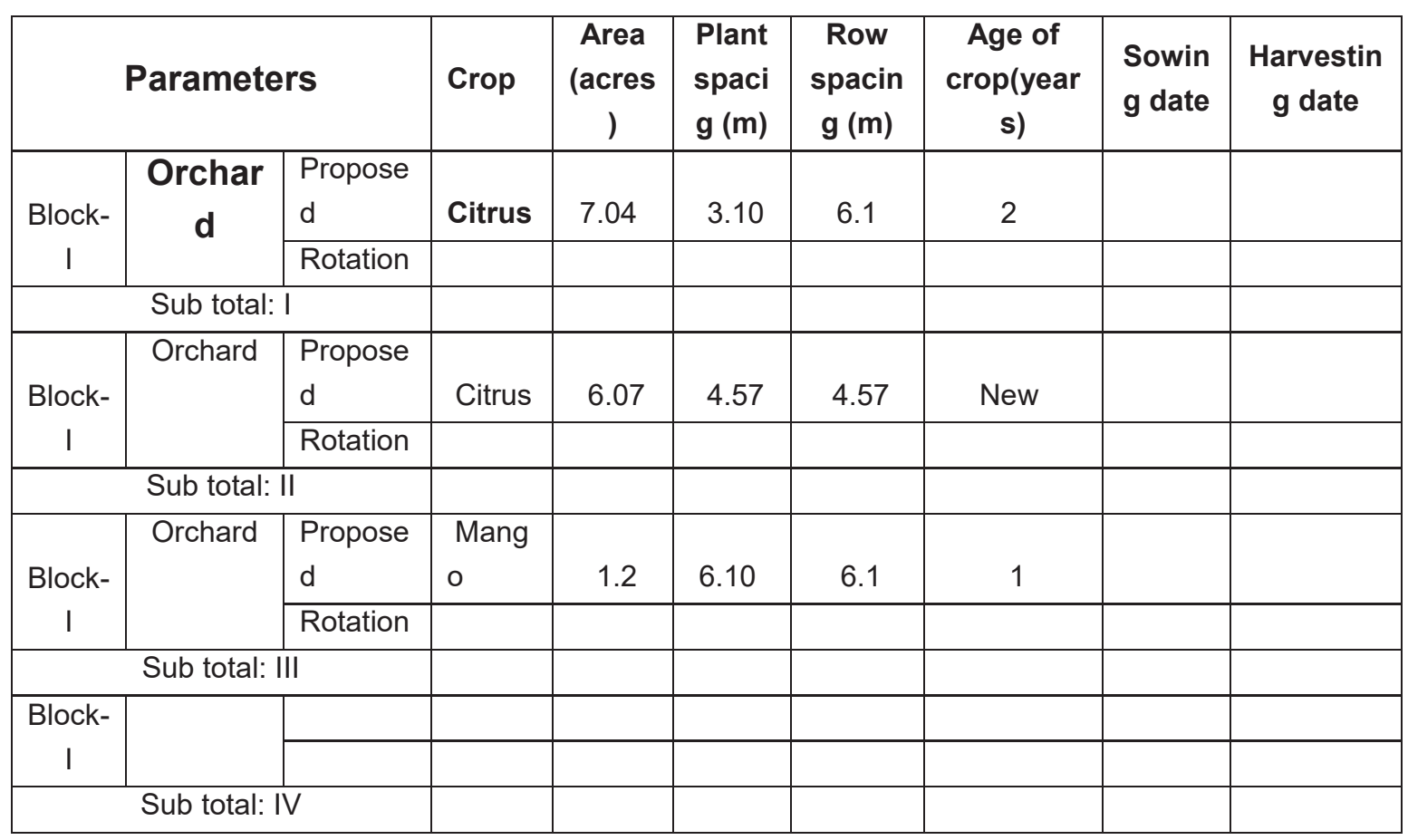




\subsubsection{Soil Type/Soil Test/Water Supply/Water Quality}

\begin{tabular}{|c|c|c|c|}
\hline \multicolumn{3}{|c|}{ Soil type/Texture } & \\
\hline \multicolumn{3}{|c|}{ Soil limitation (soil analysis report attached) } & \\
\hline \multirow{2}{*}{\multicolumn{3}{|c|}{$\begin{array}{l}\text { Soil EC , PH } \\
\text { WATER SUPPLY }\end{array}$}} & SAR \\
\hline & & & \\
\hline \multicolumn{3}{|c|}{ Available water sources } & \\
\hline \multicolumn{3}{|c|}{ 1) Canal } & \\
\hline \multicolumn{3}{|c|}{ Sanctioned discharge (LPS) } & \\
\hline \multicolumn{3}{|c|}{ Perennial/non-perennial } & \\
\hline & & Warabandi Days & \\
\hline & & Hours per Warabandi & \\
\hline & & Total Volume $(\mathrm{m} 3)$ of water for 7 days & \\
\hline \multicolumn{3}{|c|}{ 2) Groundwater } & \\
\hline \multicolumn{3}{|c|}{ a) Dug well } & \\
\hline \multicolumn{3}{|c|}{ Depth of well } & \\
\hline \multicolumn{3}{|c|}{ Diameter of well } & \\
\hline \multicolumn{3}{|c|}{ Recharge rate } & \\
\hline \multicolumn{3}{|c|}{ b) Tube well/bore well } & \\
\hline \multicolumn{3}{|c|}{ Discharge capacity (LPS) } & \\
\hline \multicolumn{3}{|c|}{ Diameter of bore (inches) } & \\
\hline \multicolumn{3}{|c|}{ Depth of water table from ground $(\mathrm{m})$} & \\
\hline \multicolumn{3}{|c|}{ 3) Storage/reservoir capacity (m3) } & \\
\hline \multicolumn{3}{|c|}{ Water quality (detailed report attached) } & \\
\hline & & Iron & \\
\hline & & $\mathrm{Ph}$ & \\
\hline & & $\mathrm{EC}(\mathrm{mmohs} / \mathrm{cm})$ & \\
\hline
\end{tabular}




\subsubsection{POWER SOURCE AND PUMP}

\begin{tabular}{|l|l|}
\hline POWER SOURCE & \\
\hline Type of power to be used & \\
\hline For electric Motor, \\
Type of connection (single/3-phase) & \\
Make/model & \\
HP of Motor & \\
RPM of Motor & ELECTRICITY NOT AVAILABLE \\
\hline For diesel engine & \\
Make & \\
HP & \\
Condition) & \\
\hline For Tractor & \\
Make/model & \\
HP & \\
Condition & \\
\hline Any other power source, if any & \\
\hline PUMP SET & \\
\hline Type & \\
Make/Model & \\
Pressure (ft/psi/bar) & \\
Flow(lps) & \\
Inlet/outlet size & \\
RPM & \\
Pulley size & \\
\hline
\end{tabular}




\subsubsection{Water Analysis Report}

\begin{tabular}{|c|c|c|c|c|c|}
\hline \multirow{2}{*}{\multicolumn{2}{|c|}{ Farmer Name : Abbass Qureshi }} & & & \multirow{3}{*}{$\begin{array}{c}\text { Tube Well } \\
10 / 5 / 2010 \\
13 / 05 / 2010\end{array}$} \\
\hline & & & Sampling Date & & \\
\hline Ph :0345-8644888 & & & $\begin{array}{l}\text { Sp Receive Date } \\
:\end{array}$ & & \\
\hline \multicolumn{2}{|c|}{ Agronomist: Ather Mehmood Khursheed } & & Report Date : : & & $31 / 05 / 2010$ \\
\hline & & & Ref.Sample & \# & 372 \\
\hline \multirow[b]{2}{*}{ Parameters } & \multicolumn{4}{|c|}{ Degree of Presence / Problem } & \\
\hline & Unit & $\underset{\mathrm{I}}{\text { Noma }}$ & Higher & $\begin{array}{c}\text { Extrem } \\
\mathrm{e}\end{array}$ & $\begin{array}{l}\text { Lab } \\
\text { Result }\end{array}$ \\
\hline $\mathrm{pH}$ & & 7 & $<7$ Acidic & $>7 \mathrm{~A}$ & 7.37 \\
\hline $\begin{array}{l}\text { Electrical } \\
\text { Conductivity } \\
\text { (Salinity) }\end{array}$ & $\begin{array}{c}\text { microsemens/c } \\
\mathrm{m}\end{array}$ & - & - & - & 2240 \\
\hline $\begin{array}{l}\text { Total dissolved } \\
\text { solids }\end{array}$ & ppm & $<500$ & $500-600$ & $>600$ & 1290 \\
\hline Hardness & ppm & $<200$ & $200-300$ & $>300$ & 312 \\
\hline Calcium & ppm & $<60$ & $60-100$ & $>100$ & 78.4 \\
\hline Magnesium & Ppm & $<25$ & $25-40$ & $>40$ & 28.21 \\
\hline Carbonate & Ppm & $<200$ & $200-600$ & $>600$ & 72 \\
\hline Bicarbonate & Ppm & $<200$ & $200-600$ & $>600$ & 176 \\
\hline Chloride (Toxic) & Ppm & $<140$ & $140-350$ & $>350$ & 198.5 \\
\hline Sulphates & Ppm & $<20$ & $20-50$ & $>50$ & 23.4 \\
\hline Sodium & Ppm & $<100$ & $100-200$ & $>200$ & 235 \\
\hline SAR & - & $<3$ & $3-9$ & $>9$ & 2 \\
\hline Potassium & Ppm & $<10$ & $10-20$ & $>20$ & 12 \\
\hline Sulphides & Ppm & $<15$ & $15-25$ & $>25$ & - \\
\hline Iron & Ppm & $<0.1$ & $0.1-0.4$ & $>0.4$ & 0.1 \\
\hline Manganese & Ppm & $<0.2$ & $0.2-0.4$ & $>0.4$ & - \\
\hline Suspended solids & Ppm & $<10$ & $10-100$ & $>100$ & 7.1 \\
\hline Boron & Ppm & $<0.5$ & $0.5-2.0$ & $>2.0$ & - \\
\hline
\end{tabular}




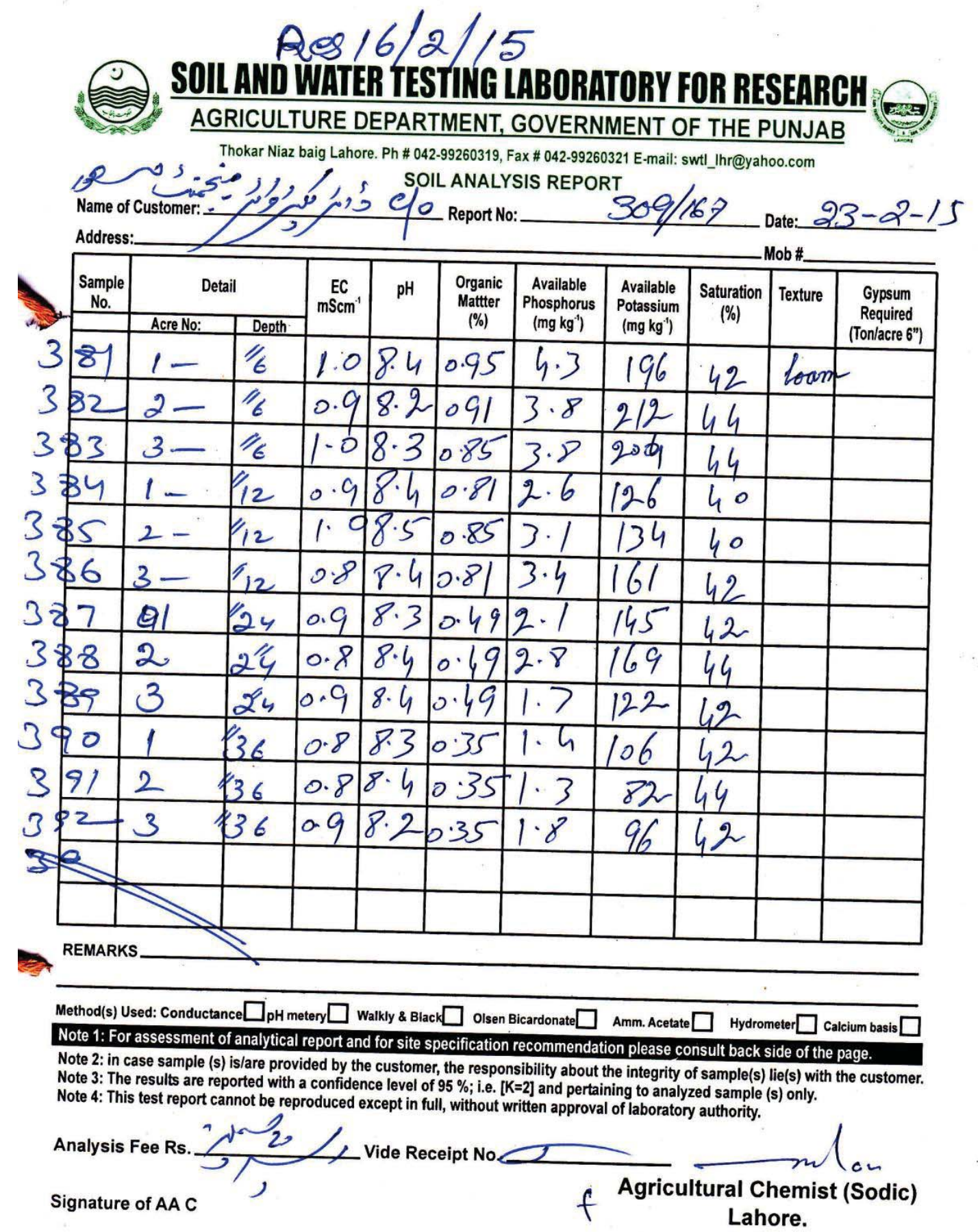

Figure 6.1. Sample Report 


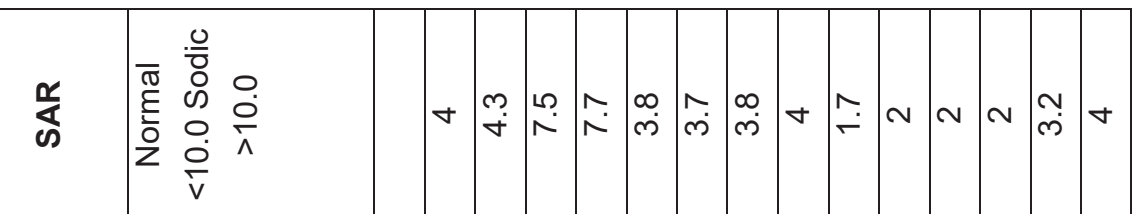

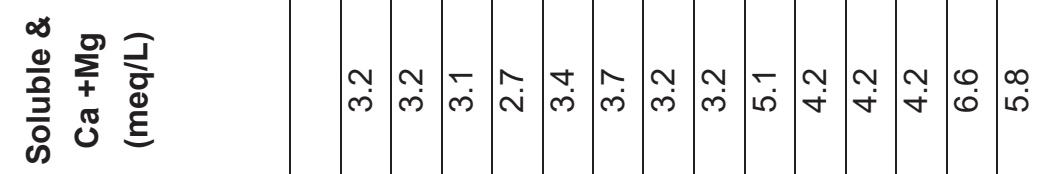

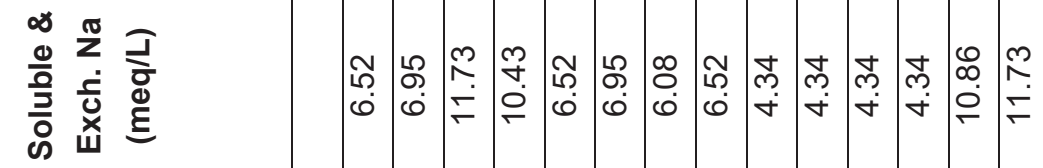

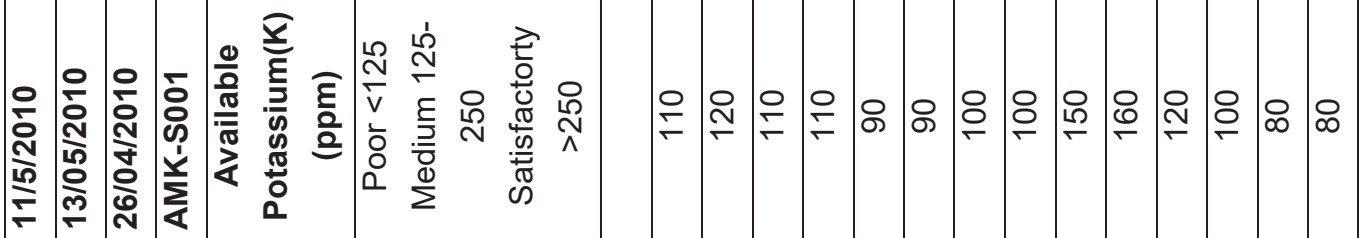
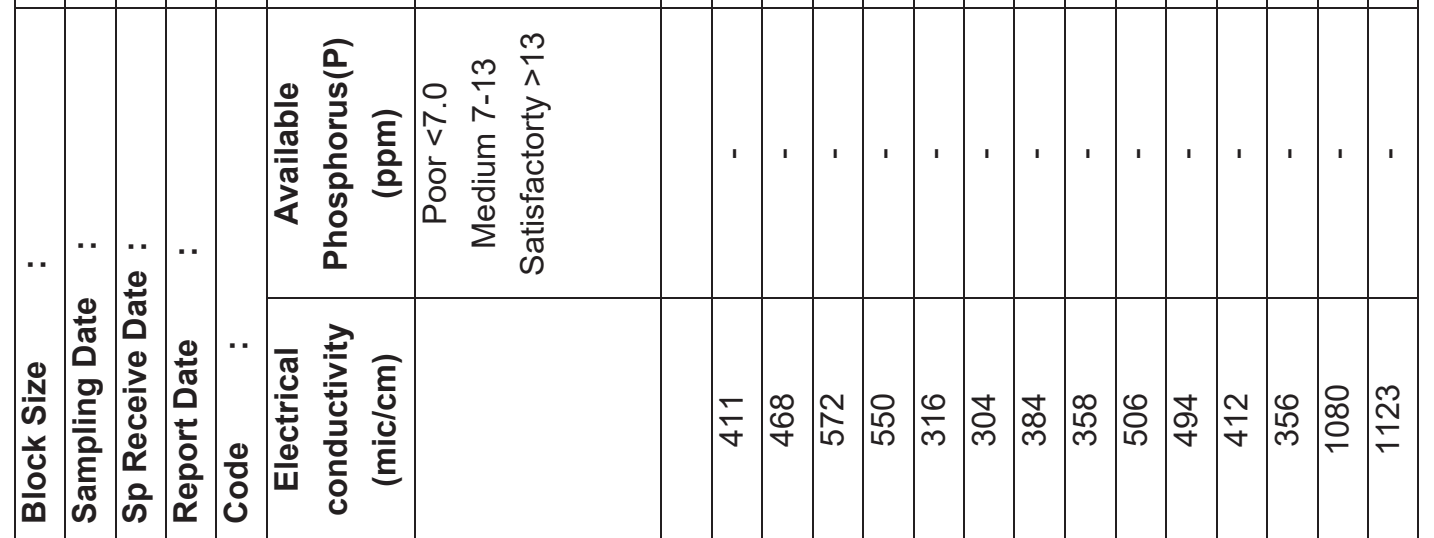

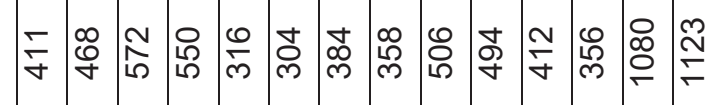

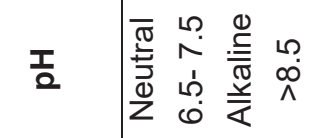

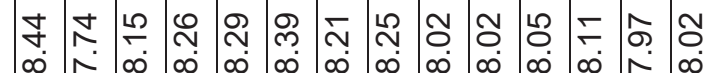

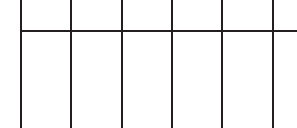

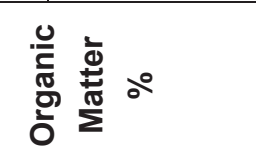

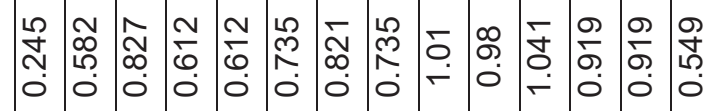

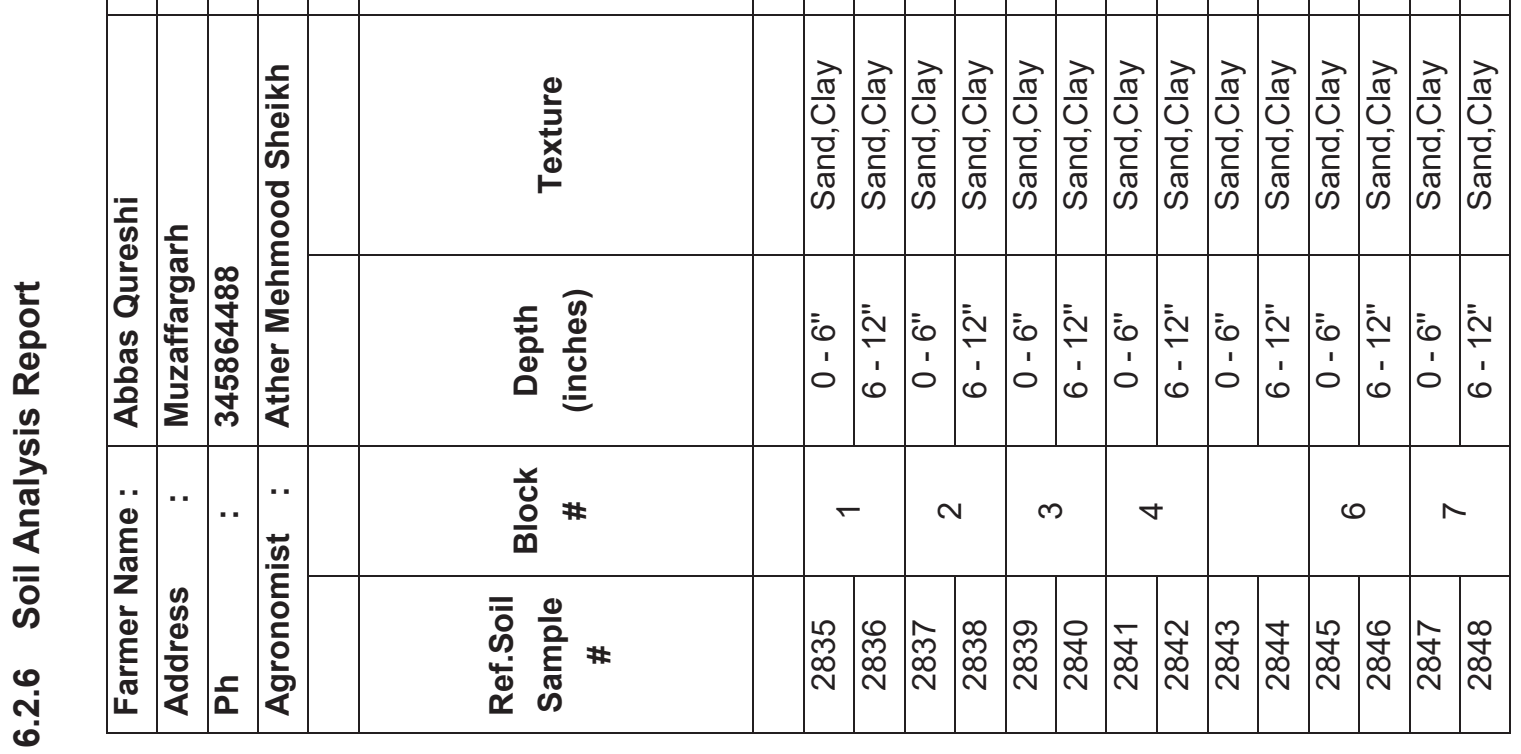


$x X X X X X X X X X X X X X X X X X X X X X X X x$

Design and Operational Manual

It is advisable to make rough map of the area and mark salient features, divide the drawn map into different blocks and number the same for soil and water sampling. This map will be finalized during designing of drip irrigation system and will show all necessary details including trippers, dian, length and location of laterals, submain and main, location of water source, power source etc.,

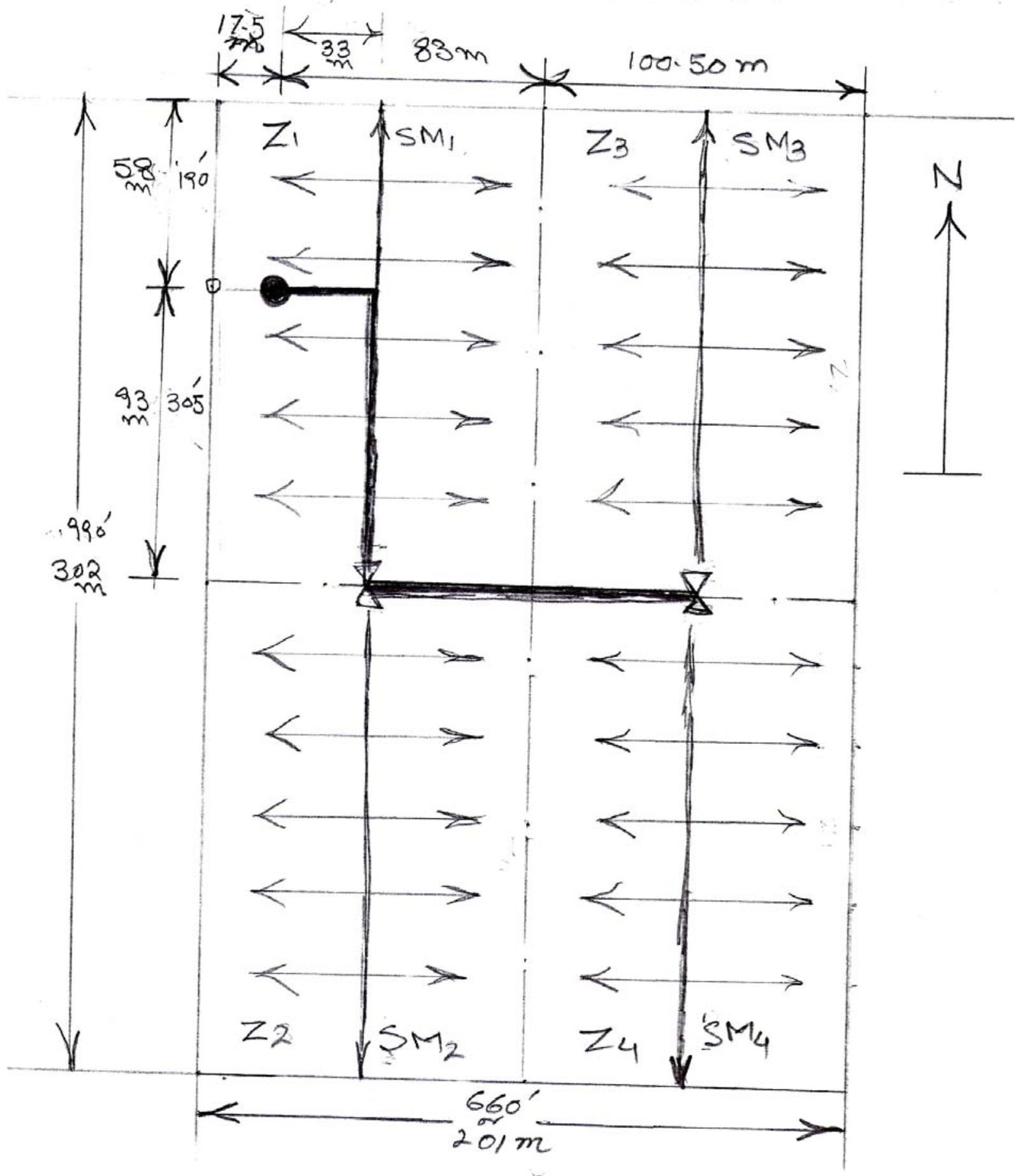

Project - Implementation Supervision Consultants (PSC)

91 


\subsubsection{Estimation of Peak Crop Water Requirement}

Estimating the reference crop evapotranspiration (ETo), using the Penman-Monteith method, and the crop evapotranspiration (ETc), through the use of the appropriate crop factor Kc, have been covered in Chapter-4 of this Manual. Evapo-transpiration is composed of the evaporation from the soil and the transpiration of the plant. Since under localized irrigation only a portion of the soil is wetted, the evaporation component of evapotranspiration can be reduced accordingly, using the appropriate ground cover reduction factor $\mathrm{Kr}$.

\section{For the design of surface and sprinkler irrigation systems:}

$\mathrm{ETc}=\mathrm{ETO} \times \mathrm{Kc}$

\section{For the design of Drip irrigation systems:}

Water Requirements for Orchard ETc= ETo x Kc x Canopy Factor/ Efficiency Percent area wetted, $100 \%$ for closely spaced crops with rows and emitter lines less than $1.8 \mathrm{~m}$.

Peak Crop Water Requirement can be tabulated as under.

\begin{tabular}{|lr|r|r|r|r|r|r|r|r|r|r|r|}
\hline \multicolumn{1}{|c}{ Month } & J & \multicolumn{1}{c|}{ F } & \multicolumn{1}{c|}{ M } & \multicolumn{1}{c|}{ A } & \multicolumn{1}{c|}{ M } & J & J & A & \multicolumn{1}{c|}{ S } & O & N & D \\
\hline Eto (mm/d) & 2.1 & 2.7 & 4.2 & 5.6 & 7 & 7.9 & 7.3 & 6.8 & 5.9 & 4.8 & 3.3 & 2.3 \\
\hline Kc (citrus) & 0.7 & 0.7 & 0.7 & 0.7 & 0.7 & 0.7 & 0.7 & 0.7 & 0.7 & 0.7 & 0.7 & 0.7 \\
\hline Crop factor at mat. & 0.57 & 0.57 & 0.57 & 0.57 & 0.57 & 0.6 & 0.57 & 0.57 & 0.57 & 0.57 & 0.6 & 0.57 \\
\hline Efficiency & 0.9 & 0.9 & 0.9 & 0.9 & 0.9 & 0.9 & 0.9 & 0.9 & 0.9 & 0.9 & 0.9 & 0.9 \\
\hline PCWR (citrus) & 0.93 & 1.20 & 1.86 & 2.48 & 3.10 & 3.50 & 3.24 & 3.01 & 2.62 & 2.13 & 1.46 & 1.02 \\
\hline Kc (mango) & 1.1 & 1.1 & 1.1 & 1.1 & 1.1 & 1.1 & 1.1 & 1.1 & 1.1 & 1.1 & 1.1 & 1.1 \\
\hline Crop factor at mat. & 0.55 & 0.55 & 0.55 & 0.55 & 0.55 & 0.6 & 0.55 & 0.55 & 0.55 & 0.55 & 0.6 & 0.55 \\
\hline PCWR (mango) & 1.41 & 1.82 & 2.82 & 3.76 & 4.71 & 5.31 & 4.91 & 4.57 & 3.97 & 3.23 & 2.22 & 1.55 \\
\hline Kc (field crops) & & & & & & & & & & & & \\
\hline CWR (field crops) & & & & & & & & & & & & \\
\hline
\end{tabular}

\subsubsection{Drawing of Project Area, Selection of zone area and No. of Operations}

A map of the scheme area be drawn and tentative number of zones having equal area of the project be selected to estimate number of operations. It is advisable that area of each of each zone must be equal so that all the discharge coming out from the pump be fully utilized in each zone area. In case all zones are not equal, some additional water has to be sent back to the water storage tank through bypass valve during irrigation of small area zones.

\subsubsection{Step 4. SELECTION OF EMITTER/DRIPPER AND FLOW RATE}

Varieties of drippers/drip tubing are available with different discharge rates, dripper spacing, characteristics and suitability for different crops. The emitter selected for the drip system: 
- Should be Inexpensive, durable and serviceable

- Should have relatively low discharge rate to keep the system cost low

- Should have higher emission uniformity $(90 \%)$ and low coefficient of variation (CV $5 \%)$

- Should have emission discharge exponent in the range of 0.4-0.7.

- Should have relatively large cross sectional area and flow path to avoid clogging

- Should have turbulent flow path and pressure compensation action

- Should not create runoff within the immediate application area

Drippers are available for 2, 4, 8 and $12 \mathrm{LPH}$ discharge. Emitter operating pressure is usually $10 \mathrm{~m}$.

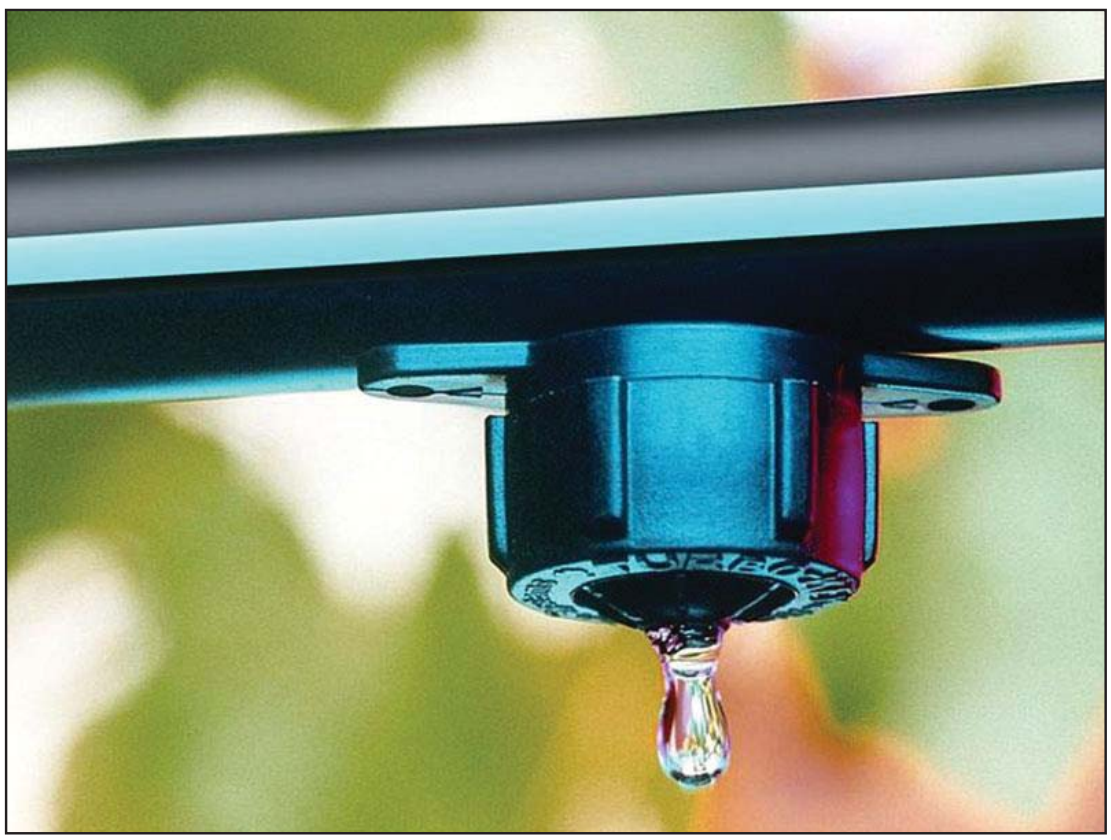

The shape of the wetted zone of the emitter depends on the physical properties

\begin{tabular}{|l|l|}
\hline $\begin{array}{l}\text { In sandy and light soil, the water will tend to go } \\
\text { straight down, and there will be less lateral movement } \\
\text { as compared to downward movement. In light soils, } \\
\text { the distribution of the water will be narrow and deeper }\end{array}$ & $\begin{array}{l}\text { (close spaced low discharged } \\
\text { emitters/Closer emitter spacing) }\end{array}$ \\
\hline $\begin{array}{l}\text { In loamy soil, the water will move slowly and will } \\
\text { spread evenly }\end{array}$ & $\begin{array}{l}\text { (average discharged emitter } \\
\text { \&/or Spacing) }\end{array}$ \\
\hline $\begin{array}{l}\text { In clay soil, the water will be absorbed very slowly } \\
\text { and there will be more lateral movement as compared } \\
\text { to downward movement. In heavy soil, the distribution } \\
\text { of the water will be relatively spherical shape, wider } \\
\text { and less depth. }\end{array}$ & \\
\hline
\end{tabular}



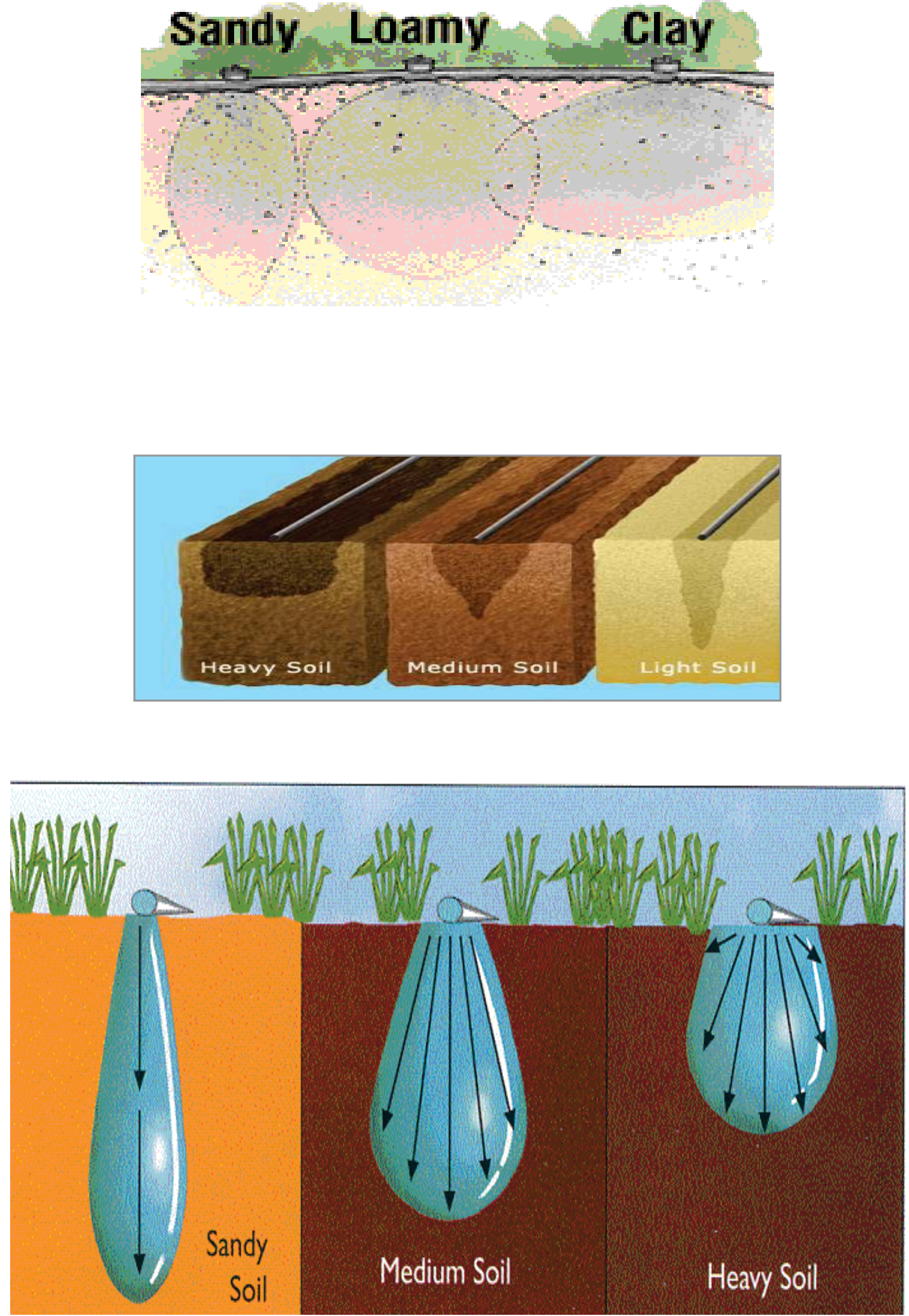

Recommended emitter spacing $(\mathrm{cm})$ for various Discharge Rates (LPH) in different soils 


\begin{tabular}{|c|c|c|c|}
\hline \multirow{2}{*}{ Soil Type } & \multicolumn{3}{|c|}{ Discharge Rates (LPH) } \\
& $2 \mathrm{LPH}$ & $4 \mathrm{LPH}$ & $8 \mathrm{LPH}$ \\
\hline Light & 40 & 80 & 120 \\
\hline Medium & 80 & 120 & 160 \\
\hline Heavy & 120 & 160 & 200 \\
\hline
\end{tabular}

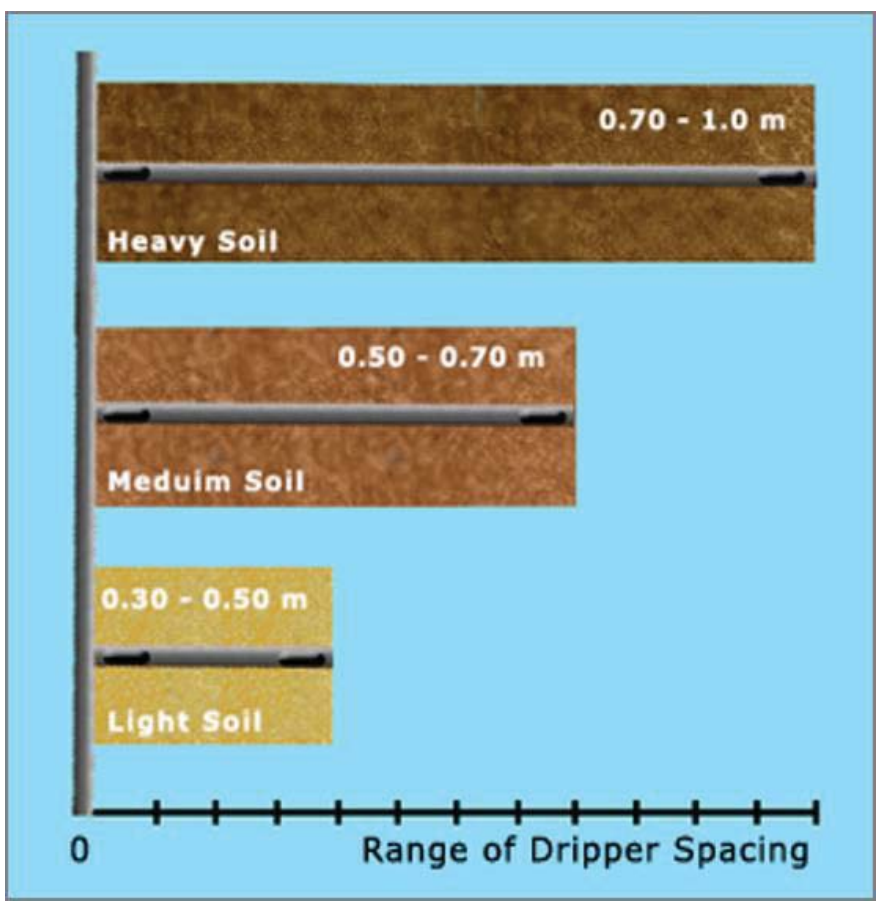

- Heavy soil recommended distance: 0.50 to 1.00 meter*

- Medium soil recommended distance: 0.40 to 0.75 meter*

- Light soil recommended distance: 0.20 to 0.50 meter*

- *The spacing between drippers depend on the root depth of the crop.

Emitter spacing should be maximum $0.5 \mathrm{~m}, 0.4-0.6$ and $0.5-0.8 \mathrm{~m}$ in light, medium and heavy soil respectively. 


\section{Emitter Discharge Exponent}

The flow or discharge from most trickle irrigation emitters or sprayers with fixed or flexible cross sections can be expressed by:

$$
q=K_{d} H^{x}
$$

in which

$q=$ emitter flow rate or discharge, $\mathrm{L} / \mathrm{hr}(\mathrm{gph})$

$K_{d}=$ discharge coefficient, which is a constant of proportionality that characterizes each emitter

$H=$ working pressure head at the emitter or sprayer, $\mathrm{m}(\mathrm{ft})$

$x=$ emitter discharge exponent

The value of $x$ characterizes the flow regime and discharge versus pressure relationship of the emitter. The lower the value of $x$, the less discharge will be affected by variations in pressure (see Fig. 17.1). Noncompensating simple orifice and nozzle emitters and sprayers are typically fully turbulent and $x=$ 0.5 . For fully compensating emitters, $x=0.0$. The exponent of long-path emitters is usually between 0.7 and 0.8 . For vortex sprayers or emitters, $x$ is about 0.4 . The exponent of tortuous path emitters usually falls between 0.5 and 0.7 .

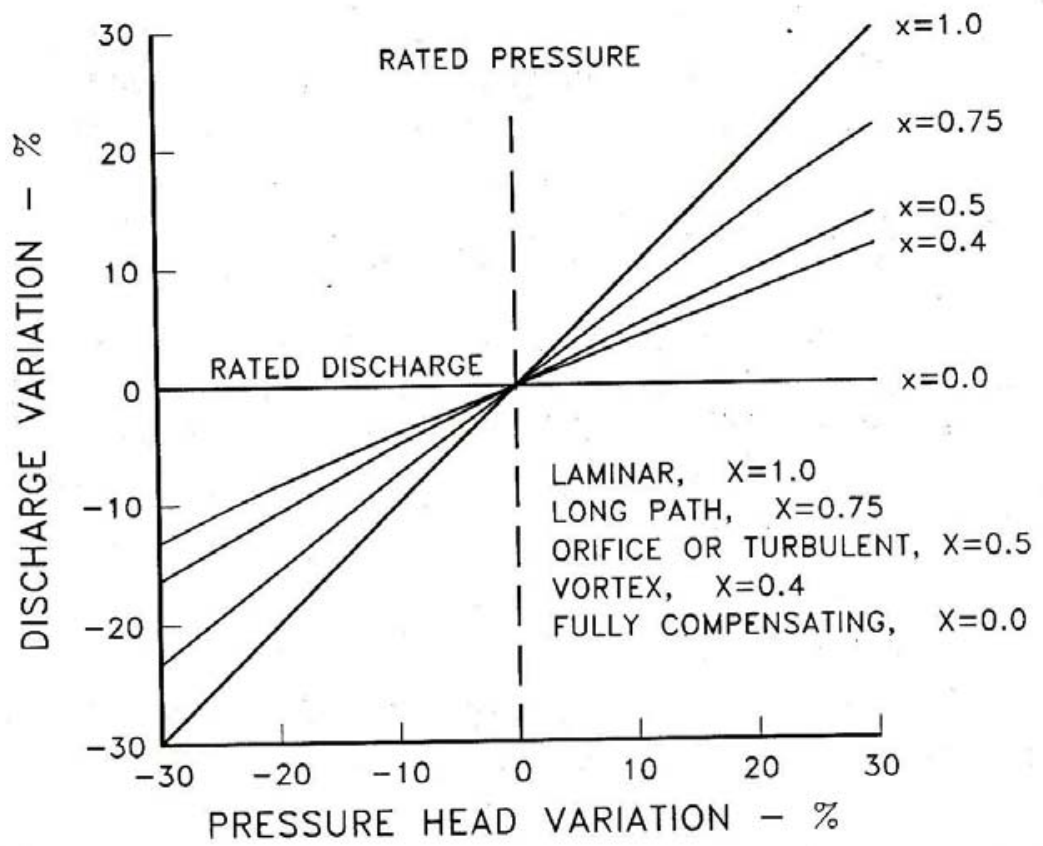

FIG. 17.1. Discharge Variation Resulting from Pressure Changes for Emitter Having Differen Discharge Exponents (Adapted from: Karmeli and Keller, 1975 (Fig. 2.7)). 
Calculation of $X$ value for a 4 LPH discharge emitter

\section{Performance Graph-J-Turbo Line ${ }^{\circledR} 16 \mathrm{~mm}$ OD}

\section{Pressure (psi)}

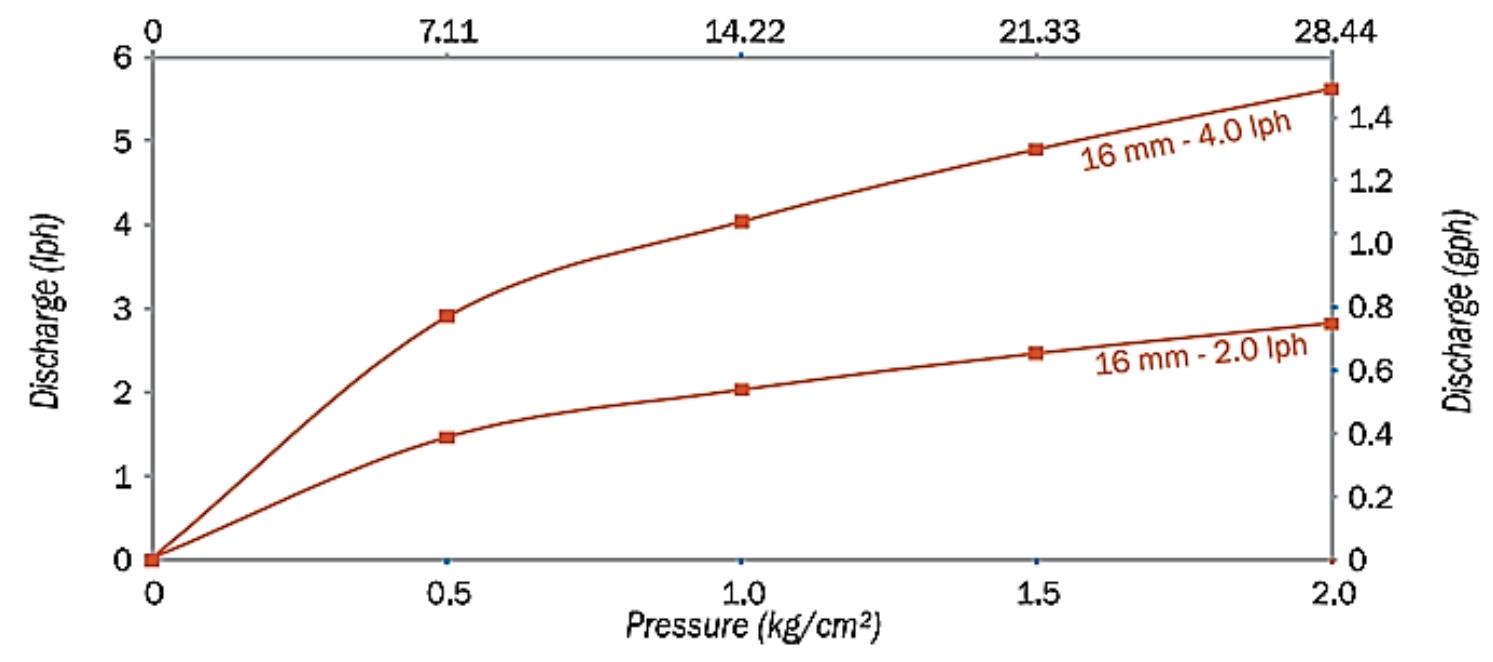

\begin{tabular}{|c|c|c|c|c|}
\hline S. No. & $Q(\mathrm{lph})$ & $P(m)$ & $\% \Delta \mathbf{Q}$ & $\% \triangle \mathbf{P}$ \\
\hline 1 & 4 & 10 & -- & - \\
\hline 2 & 5 & 15 & $25 \%$ & $50 \%$ \\
\hline 3 & E & 20 & $50 \%$ & $100 \%$ \\
\hline \multicolumn{5}{|c|}{ Emitter Discharge Exponent $(\mathrm{x})$ : } \\
\hline \multicolumn{5}{|c|}{$x=\log (q 1 / q 2) / \log (P 1 / P 2)$} \\
\hline \multicolumn{5}{|c|}{ with aforementioned data, $X=0.584$} \\
\hline
\end{tabular}

Most of the water emitter flow regime is fully turbulent with an exponent value equal to 0.5 . In order to ensure a high uniformity of water application over the field, the differences in the discharge of the emitters should be kept to the minimum possible and in no case exceed 10 percent. These criteria were established by J. Christiansen for sprinklers and are now applied in all pressurized systems. As a general rule, the maximum permissible difference in pressure between any two emitters in operation should be no more than 20 percent. The lateral lines with emitters must be of a size that does not allow a loss of head (pressure) due to friction of more than 20 percent. In case emitter operating pressure is 01 bar or 10 meter, the head loss in the selected lateral must not be more than 02 meter. 


\section{Coefficient of Variation (Cv) of Emitter}

Coefficient of Variation is a measure of consistency in the flow. If we randomly select several emitters and measure the discharge of each at nominal pressure, the consistency in the results will reveal Cv of the product.

$$
C v=\frac{\text { Standard Deviation of Discharge Rate }}{\text { Average Discharge Rate of Sample }}
$$

\begin{tabular}{|c|c|}
\hline Cv $\%$ & Classification \\
\hline $65 \%$ & Excellent \\
\hline $5 \%-7 \%$ & Goud \\
\hline $7 \%-11 \%$ & Plarginal \\
\hline$\% 11 \%$ & Pogr \\
\hline
\end{tabular}

\subsubsection{No. of Emitters per Plant, No. of Drip Lines per Row and optimal Distance between two Laterals}

No. of emitters/drippers per plant can be 2, 4 or 6 . No. of drip lines per row can be 02 .

Optimal distance between two laterals can be 20 feet $(6.1 \mathrm{~m})$

\subsubsection{Step 6. Calculation of Plant Area and Total Number of Plants and Minimum No. of Emitters per plant}

\section{Plant Area}

Individual plant such as orchards will be irrigated by individual emitters. Area of each plant will be required for estimation of number of plants in scheme as well as for calculation of water requirements. Area for individual plant can be determined by using following relationship.

\begin{tabular}{rll}
\multicolumn{1}{|l}{$\mathbf{A}_{\mathbf{p}}$} & $=\mathbf{S}_{\mathbf{P}} \times \mathbf{S}_{\mathbf{R}}$ \\
Where & & \\
$\mathbf{A}_{\mathbf{p}}$ & $=$ & Plant area $\left(\mathrm{m}^{2}\right)$ \\
$\mathbf{S}_{\mathbf{P}}$ & $=$ & Plant spacing $(\mathrm{m})$ \\
$\mathbf{S}_{\mathbf{R}}$ & $=$ & Row spacing $(\mathrm{m})$
\end{tabular}

No. of Plants

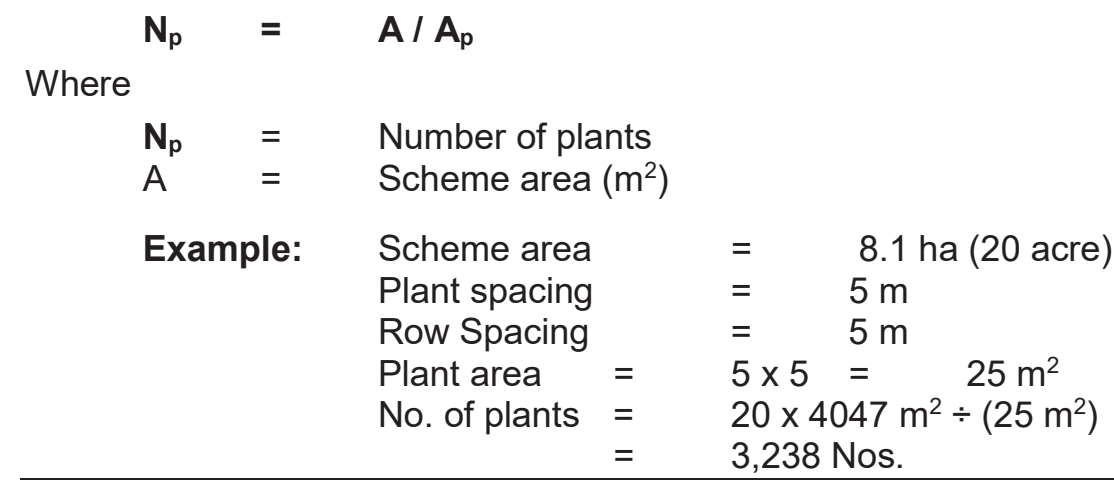


For row crops, almost entire field will be covered by the crops and hence number of plants is not important as their water requirements will be calculated based on the shaded area which is usually taken as $100 \%$.

Note: Number of plant is not important for sprinkler system

\subsubsection{Emitter Placement Geometry}

In drip irrigation systems, the lateral lines are the pipes on which the emitters are attached. Water flows from the manifold into the laterals, which are usually made of plastic tubing ranging from 10 $\mathrm{mm}$ to $25 \mathrm{~mm}$ in diameter. Continuous-size tubing provides better flushing. The layout of lateral lines should be such that it provides the required emission points for the crop to be irrigated. Sometimes two laterals per row of trees are needed. Other methods of obtaining more emission points per tree are zigzag and "snake" layouts and use of pigtail lines looped around or between the trees. Figs 6.1 to 6.4 show various lateral layouts for widely spaced permanent crops.

\section{Single line for each row of tree}

For a drip system with straight laterals of single drip emitters and emitter spacing (Se) equal to or less than optimum emitter spacing (Se') then percent area wetted Pw, can be computed by following equation

$$
P_{w}=\frac{e S_{e} S_{w}}{S_{p} S_{r}} \times 100
$$

Where:

$\mathrm{Pw}=$ Percent area wetted

$\mathrm{e}=$ number of emission points per plant.

$\mathrm{Se}=$ spacing between emitters on a lateral, $\mathrm{m}$ or feet.

$\mathrm{Sw}=$ width of the strip that would be wetted by emitters on a lateral at Se': or closer, $\mathrm{m} / \mathrm{feet}$.

$\mathrm{Sp}=$ plant spacing in the row, $\mathrm{m} / \mathrm{feet}$.

$\mathrm{Sr}=$ plant row spacing, $\mathrm{m} / \mathrm{feet}$.

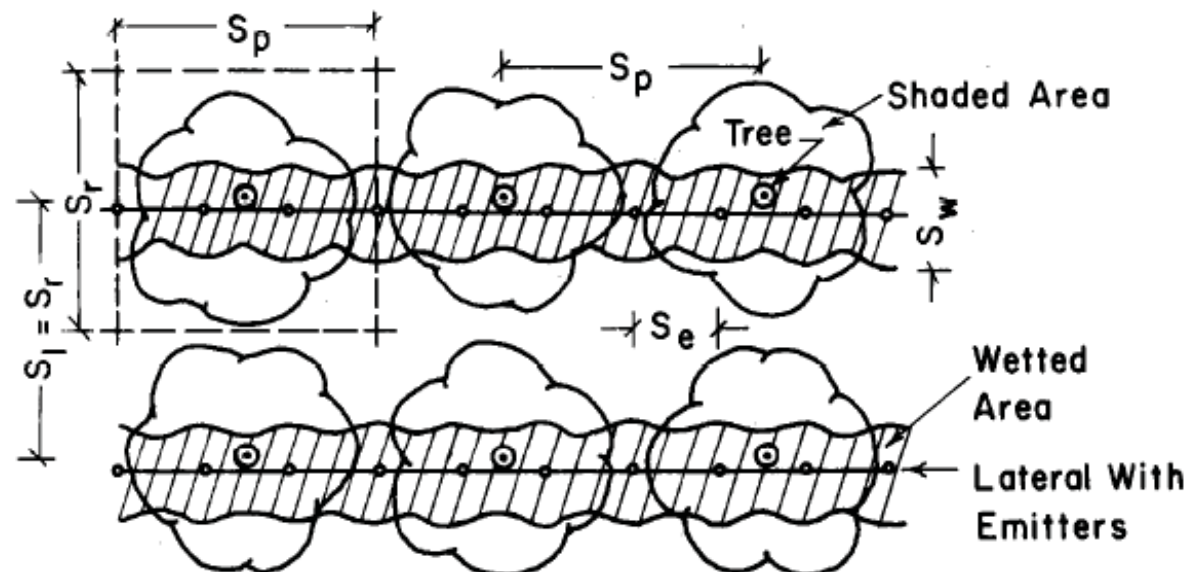

Fig. 4.1 Single lateral line for each row of plants 
Double line for each row of tree

For drip systems with double laterals or zigzag, pigtail, or multi exit layout, wetted area Pw, can be computed by following equation.

$$
P_{w}=\frac{e S_{e}^{\prime}\left(S_{e}^{\prime}+S_{w}\right)}{2\left(S_{p} S_{r}\right)} \times 100
$$

For double laterals, the two laterals should be placed apart at a distance equal to Se'. This spacing gives the greatest Aw, and leaves no extensive dry areas between he double lateral lines. For the greatest Aw, with zigzag, pigtail, and multi exit layouts, the emission points should be placed at a distance equal to Se' in each direction.

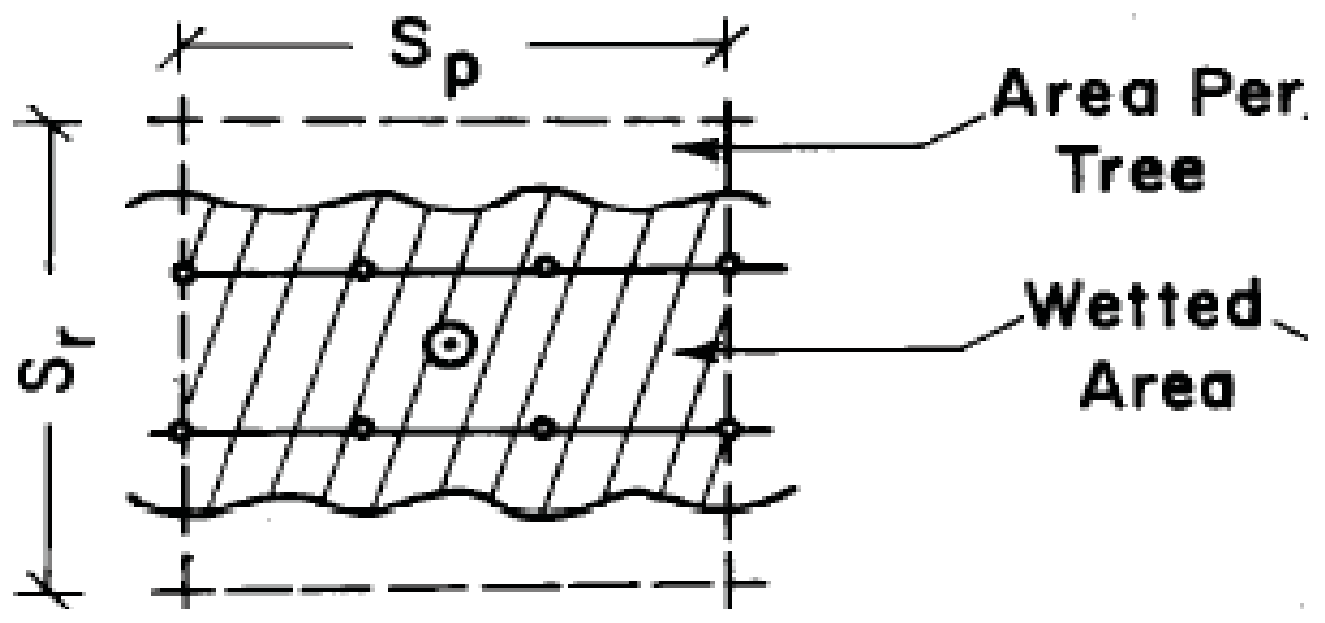

Fig. 6.2 Two lateral lines for each row of plants

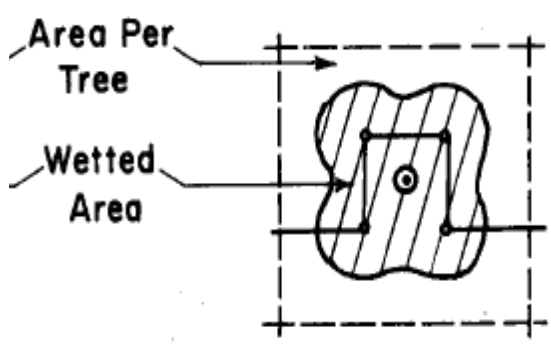

Fig. 6.3 Zigzag style of lateral placement along plant stem

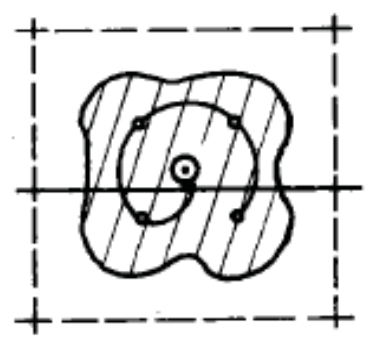

Fig. 6.4 Pig tail style of lateral placement along plant stem 


\section{Spray System}

For a drip system with spray emitters, Pw, can be computed by following equation.

$$
\mathrm{P}_{\mathrm{w}}=\frac{\mathrm{e}\left[\mathrm{A}_{\mathrm{g}}+\left(1 / 2 \mathrm{~S}_{\mathrm{e}}^{\prime} \times \mathrm{PS}\right)\right]}{\left(\mathrm{S}_{\mathrm{p}} \mathrm{S}_{\mathrm{r}}\right)} \times 100
$$

Where;

As = estimate of the soil surface area wetted per sprayer from field tests with a few sprayers, square meters/ square feet/.

$\mathrm{PS}=$ perimeter of the area directly wetted by the test sprayers, feet $/ \mathrm{m}$.

$1 / 2 \mathrm{Se}$ ' = one-half the Se' values for homogeneous soils, $\mathrm{m} / \mathrm{feet}$

\section{Minimum No. of Emitters}

For micro irrigation system (drip, bubbler, micro jets) type and numbers of emitters are selected based on the soil, crop and area to be wetted. The number of emitters is based on the volume of wetting for each plant. The number of emitters required at each plant or tree to wet sufficient root zone can be calculated by the formula:

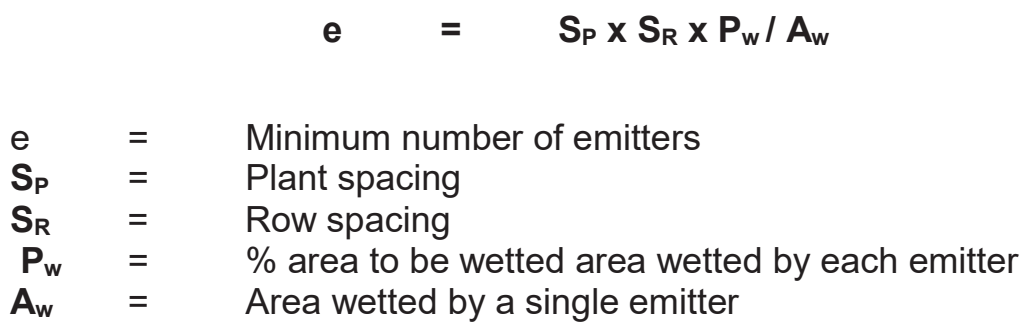

This will give the number of emitters per plant. If the number is a fraction, the next larger number should be used.

Example:

Number of emitters $=(5 \mathrm{~m} \times 5 \mathrm{~m} \times 40 \%$ wetted area $) \div\left(1.8 \mathrm{~m}^{2}\right.$ wetted by each emitter $)$

$$
=\quad 5.5 \text { say } 6 \text { Emitters. }
$$

Six emitters must be used to wet sufficient root zone. No. of drip lines can be selected as 02 .

\subsubsection{Calculation Of Total Length Of Lateral, Number Of Emitters In One Zone And Total Number Of Emitters}

The length of lateral required for the scheme area under micro irrigation system can be calculated as follows: 


\section{Orchard/Row Crops:Double Lateral or Single Lateral per plant row}

$$
\text { L } \quad=\quad \text { K. A. NI./ Ls }
$$

$\begin{array}{lll}\mathrm{K} & = & 4047 \\ \mathrm{~A} & = & \text { Area (acres) } \\ \mathrm{L} & = & \text { Lateral length }(\mathrm{m}) \\ \mathrm{NI} & = & \text { Number of laterals per plant row } \\ \mathrm{LS} & = & \text { Lateral spacing, } \mathrm{m}\end{array}$

Orchard: Pigtail/ Loop with single Lateral per plant row

$$
\mathrm{L}=\mathrm{A} \times \mathrm{K} /[\mathrm{Ls}+(\mathrm{Np} \times \mathrm{Lr})]
$$

$\begin{array}{lll}\mathrm{L} & = & \text { Lateral length, } \mathrm{m} \\ \mathrm{A} & = & \text { Area (acres) } \\ \mathrm{K} & = & 4047 \\ \mathrm{Ls} & = & \text { Lateral spacing, } \mathrm{m} \\ \mathrm{Np} & = & \text { Number of plants } \\ \mathrm{Lr} & = & \text { Length of loop }(\mathrm{m})\end{array}$

Similarly, lateral length for sprinkler system can be calculated as

$$
\mathrm{L}=\mathrm{A} \times \mathrm{K} / \mathrm{LS}
$$

\section{TOTAL NUMBER OF EMITTERS}

Total no. of emitters in a scheme area or in a zone, can be calculated using following relationship.

\section{Orchard:}

$$
\mathrm{N} \quad=\quad \mathrm{Np} \times \mathrm{e}
$$

$\mathrm{N}=\quad$ Total number of emitters

$\mathrm{e} \quad=\quad$ Number of emitters per plant

$\mathrm{Np}=$ Total no. of plants

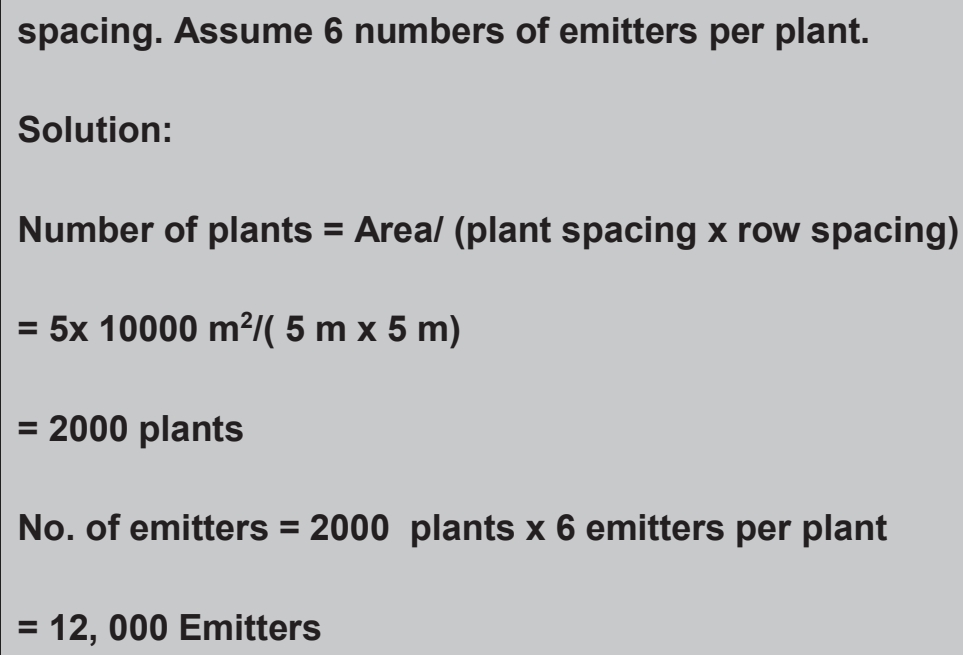




\section{Row crops:}

Total number of emitters $\quad=\quad$ Total lateral length / Emitter spacing

Similarly, the numbers of sprinklers are calculated based on the following pattern using relationship:

Number of sprinklers $\quad=\quad \mathrm{A} /(\mathrm{S} \times \mathrm{L})$

A $\quad=$ Area, Acres (hectares)

$\mathrm{L} \quad=\quad$ Sprinkler spacing between lateral or Lateral spacing

S $\quad=$ Sprinkler spacing at lateral or sprinkler spacing

\subsubsection{Calculation of Total Flow Rate Requirements (Iph)}

For micro irrigation system, total flow rate required for the hydro-zone and/or scheme area can be calculated using the following relationships.

For Orchard:

$$
\mathbf{Q}=\quad \mathrm{Np} \times \mathrm{e} \times \mathrm{q}
$$

$\mathrm{Q}=\quad$ Total Flow Rate, Iph

$\mathrm{q}=$ emitter flow rate, Iph

Example: Orchard

Total flow rate $=3238 \times 6 \times 8 \mathrm{Iph}=155,424 \mathrm{LPH}$

$=\quad 43.2 \mathrm{LPS}$

$=\quad 155.424 \mathrm{~m} 3 / \mathrm{hr}$

\section{For Row Crops:}

$$
\begin{aligned}
& \mathbf{Q}=e \times q \\
& \mathbf{Q}=\mathrm{L} \times \mathrm{q} \times \mathrm{S}_{\mathrm{e}}
\end{aligned}
$$

Where,

$\mathrm{Se} \quad=$ Emitter spacing

Similarly for sprinkler irrigation system, total flow will be calculated based on the following relationship.

$$
\text { Q = Ns } \times \text { Qs }
$$


Ns $=$ Number of sprinklers operating in a zone

Qs $\quad=\quad$ Sprinkler flow rate, Iph

\subsubsection{Calculation of Application Rate (Mm/Hr)}

Application rate is the depth of water uniformly distributed over the entire scheme area and can be estimated using following relationship.

$$
I=Q / A
$$

$\mathrm{I}=$ Application Rate $(\mathrm{mm} / \mathrm{hr})$

$\mathrm{Q}=$ Total flow rate, $\mathrm{Lph}$

A $=$ Area, $\mathrm{m}^{2}$

For Orchard:

Application rate $=155.424 \mathrm{~m}^{3} / \mathrm{hr} \times 1000 /(20$ * $4047 \mathrm{~m} 2)$

$=1.92 \mathrm{~mm} / \mathrm{hr}$

For Row crops:

Application rate $=\quad \mathrm{m}^{3} / \mathrm{hr} \times 1000 /(20 * 4047 \mathrm{~m} 2)$

$=\mathrm{mm} / \mathrm{hr}$

Application rate for sprinkler system can be calculated using above relationship. Average application rate can also be calculated as:

\section{$\mathrm{I}=\mathrm{K} \times \mathrm{q} /(\mathrm{S} \times \mathrm{L})$}

$\mathrm{I}=$ Application rate, $\mathrm{mm} / \mathrm{hr}(\mathrm{in} / \mathrm{hr})$

$\mathrm{K}=$ Conversion constant, 60 for metric unit (96.3 for English unit)

$\mathrm{Q} \quad=$ Sprinkler discharge, L/min (gpm)

$\mathrm{S} \quad=$ Sprinkler spacing along lateral, $\mathrm{m}(\mathrm{ft})$

$\mathrm{L} \quad=$ Lateral spacing, $\mathrm{m}(\mathrm{ft})$

\subsubsection{Total Operation Time (Hrs)}

Operation time required to provide irrigation depth to meet daily consumptive use can be estimated using following relationship. The same relationship can be applied for both the Micro Irrigation system and sprinkler irrigation system. 


\section{$\mathrm{T}=\mathrm{Cu} / \mathrm{I}$}

$\mathrm{T}=$ Daily Operation time, hrs

\section{Example: Orchard}

Daily operation hours $\quad=\quad 2.4 \div 1.92$

$$
=\quad 1.25 \mathrm{hrs}
$$

Operation time can also be calculated using following equation.

$\mathrm{Ta}=\mathrm{IR} /(\mathrm{Np} \times \mathrm{q})$

Where

$\mathrm{Ta}=$ Daily Operation Time, hrs

$\mathrm{IR}=$ Gross irrigation requirement, $\mathrm{mm}$

$\mathrm{Np}=$ No. of emitters per plant

$\mathrm{q}=$ Emitter flow rate, $\mathrm{LPH}$

\section{Example orchard:}

Total area under HEIS $\quad: 4.5$ Acres

ETo $\mathrm{mm} /$ day $\quad: 7.9$

Kc $\quad: 0.7$

Plant spacing $\mathrm{m} \quad: 6.1$

Row Spacing $\mathrm{m} \quad: 6.1$

Canopy Diameter $\quad: 5.18$

Emitter Flow Rate $\quad: 8 \mathrm{LPH}$

Calculate Design Steps from 1-10

\section{Solution:}


Calculation of Design Parameters of HEIS Design

\begin{tabular}{|c|c|c|c|c|}
\hline $\begin{array}{l}\text { Sr. } \\
\text { No }\end{array}$ & Parameters & Formula Description & Units & Zone I \\
\hline 1 & Total area under HEIS & A & Acres & 4.5 \\
\hline 2 & $\begin{array}{l}\text { Reference } \\
\text { Evapotranspiration (ET) }\end{array}$ & & $\mathrm{mm} / \mathrm{d}$ & 7.9 \\
\hline 3 & Crop Factor $(\mathrm{Kc})$ & & & 0.70 \\
\hline 4 & Plant spacing & & $\mathrm{m}$ & 6.10 \\
\hline 5 & $\begin{array}{l}\text { Row spacing/ Lateral } \\
\text { spacing }\end{array}$ & & $\mathrm{m}$ & 6.10 \\
\hline 6 & Canopy Diameter & $\mathrm{Cd}$ & $\mathrm{m}$ & 5.18 \\
\hline 7 & Canopy Area & $\begin{array}{l}\mathrm{Ca}=3.1416 \times \text { Canopy diameter } \\
\wedge 2 / 4\end{array}$ & $\mathrm{~m} 2$ & 21.1 \\
\hline 8 & Canopy factor at maturity & $\begin{array}{l}\text { Cf=Canopy Area/Plant Spacing } \\
\text { x Lateral Spacing }\end{array}$ & Fraction & 0.57 \\
\hline 9 & $\begin{array}{l}\text { Irrigation system } \\
\text { efficiency }\end{array}$ & & $\%$ & 90 \\
\hline 10 & & & & 8.0 \\
\hline 11 & Emitter flow rate & & $\mathrm{LPH}$ & 8.0 \\
\hline 12 & $\begin{array}{l}\text { Optimal wetted width of } \\
\text { each emitter }(30 \mathrm{~cm}) \\
\text { below soil surface at peak } \\
\text { water demand) }\end{array}$ & & & \\
\hline 13 & $\begin{array}{l}\text { No. of emitter/dripper per } \\
\text { plant }\end{array}$ & & Nos. & 6.0 \\
\hline 14 & $\begin{array}{l}\text { Emitter spacing along } \\
\text { plant canopy }\end{array}$ & & & \\
\hline 15 & No. of drip lines per row & & Nos. & 2.0 \\
\hline 16 & $\begin{array}{l}\text { Optimal distance between } \\
\text { two Laterals }\end{array}$ & & $\mathrm{m}$ & 6.10 \\
\hline 17 & $\begin{array}{l}\text { Irrigation cycle (assume } \\
\text { one day) }\end{array}$ & & Days & 1.0 \\
\hline 18 & $\begin{array}{l}\text { Peak daily consumptive } \\
\text { use per day }\end{array}$ & $\begin{array}{l}\text { Reference ET x crop factor } x \\
\text { Canopy factor/Efficiency }\end{array}$ & $\mathrm{mm} / \mathrm{d}$ & 3.50 \\
\hline 19 & Total no. of plants & $\begin{array}{l}\text { Area } \times \text { 4047/Plant Spacing } x \\
\text { Lateral Spacing }\end{array}$ & Nos. & 489 \\
\hline 20 & Total drip line length & $\begin{array}{l}\text { Area x 4047/Lateral Spacing } x \\
\text { No. of drip lines per row }\end{array}$ & $\mathrm{m}$ & 5971 \\
\hline 21 & $\begin{array}{l}\text { Total no. of } \\
\text { emitters/drippers }\end{array}$ & $\begin{array}{l}\text { Total no. of plants } x \text { drippers } \\
\text { per plant }\end{array}$ & Nos. & 2937 \\
\hline 22 & Average emitter spacing & $\begin{array}{l}\text { Total drip line length/Total no. } \\
\text { of emitters }\end{array}$ & $\mathrm{m}$ & 2.03 \\
\hline 23 & Total flow rate & $\begin{array}{l}\text { Total no. of emitters } x \text { emitter } \\
\text { flow rate }\end{array}$ & LPH & 23492 \\
\hline 24 & Application rate & $\begin{array}{l}\text { (Total flow rate/1000)/(Area } x \\
4047) \times 1000\end{array}$ & $\mathrm{~mm} / \mathrm{hr}$ & 1.29 \\
\hline 25 & Operation time* & $\begin{array}{l}\text { Peak daily consumptive use } \\
\text { per day/Application rate }\end{array}$ & Hrs & 2.72 \\
\hline
\end{tabular}




\subsection{PIPES}

As a rule, pressurized irrigation schemes are composed of water lifting devices, piped networks, water delivery devices, and pressure and water control devices. Sometimes water gravitates in the system and no water lifting devices required in the system.

Some of the systems require less pressure for operation and other require more to operate. Keeping in view all the limitations which may technical, economical and on ground demand, the type and size of the pipe is decided for the irrigation schemes to be installed.

In case where water is lifted at higher elevations the material and equipment used in the start of the schemes withstands higher pressure. The reverse is true when water is flowing from higher elevation to lower elevation the material used at the end of the scheme withstand higher pressure. The design engineers must be careful in selection of materials for such types of schemes.

\subsubsection{Selection of Pipes}

The most common pipes used for pressurized irrigations systems are;

- Fiber- cements pipes known as Asbestos cement pipes

- Un plasticized polyvinyl chloride pipes (uPvc)

- Polyethylene pipes

- Hoses

- Aluminum pipes

- Steel pipes

Very often design engineer is confronted with the question of which type of pipe should be used for what diameter, their life expectancy and the installation cost.

For the sizing of economic pipe diameter the Smit (1993) proposed the following combination of pipe sizes and types of pipes for south African conditions.

- For size up to $50 \mathrm{~mm}=$ Polyethylene pipes

- For size from $50 \mathrm{~mm}-110 \mathrm{~mm}=\mathrm{u}$ Pvc Pipes

- $\quad$ For Sizes from $110 \mathrm{~mm}-350 \mathrm{~mm}=$ Fiber cement pipes

- For sizes larger than $350 \mathrm{~mm}=$ steel pipes

However, these norms vary from country to country because of combined effect of pipes prices, transportation and installation cost.

There is large fluctuation in rates of pipes as derivative of petroleum product.

In our conditions sizing and selection of pipes for pressurized irrigations schemes is based on pressurized non bursting velocity, financial limits and water demands. 
$\mathrm{D}=63.25(\mathrm{Q} / 3.141 \mathrm{x} \mathrm{v})^{1 / 2}$

Where $D=$ Dia of pipe in inches

$\mathrm{Q}=$ Discharge in Ips

$V=$ velocity in $\mathrm{m} / \mathrm{sec}$ (assumed $1.0-1.5 \mathrm{~m}$ )

\subsubsection{Fiber Cement Pipes}

Fiber cement pipes or Asbestos pipes are made from port land cement reinforced by fibers, the formulation of which contains chrysotile Asbestos. The pipe is very smooth internally and thus friction coefficient is very low. It can easily be damaged if poorly handled. At times, cracks occurring during transports and installation only become noticeable later on during testing. The yet an other disadvantage of this pipe is its poor fitting. Diverse kind of specials is used for jointing of pipes.

The standards available for AC pipe are;

ISO 160:1980, ISO 390,ISO 7337, SAZS 113:2000

NOMINAL AND OUT SIDE DIAMETER AT FINISHED ENDS OF FIBER- CEMENTS PRESSURE PIPES SAZS -113: 2000

\begin{tabular}{|c|c|c|c|}
\hline Nominal dia $(\mathbf{m m})$ & Class & Outside dia $(\mathbf{m m})$ & $\begin{array}{l}\text { Tolerance at outside } \\
\text { dia }(+/-)\end{array}$ \\
\hline 50 & A II & 69.1 & 0.6 \\
\hline 75 & A II & 95.6 & 0.6 \\
\hline 100 & A II & 121.9 & 0.6 \\
\hline 125 & A II & 149.9 & 0.6 \\
\hline 150 & A II & 177.3 & 0.6 \\
\hline
\end{tabular}

CLASSIFICATION OF FIBER CEMENT PRESSURE PIPES ISO-160: 1980

\begin{tabular}{|c|c|c|}
\hline \multirow{2}{*}{ CLASS } & \multicolumn{3}{|l|}{ Work hydraulic test pressure } \\
\cline { 2 - 3 } & Bar & Mpa \\
\hline 5 & 5 & 0.5 \\
\hline 6 & 6 & 0.6 \\
\hline 10 & 10 & 1.0 \\
\hline 12 & 12 & 1.2 \\
\hline
\end{tabular}




\subsubsection{Un-plasticized Polyvinyl Chloride Pipes (UPVC)}

UPVC pipes and fittings are made by PVC- $U$ polymer, to which some additives are incorporated in order to facilitate manufacture. ISO - 1620 provides for the testing of this polymer. These pipes are cheaper, light in weight, resistant to corrosion, long life and offer less resistance to flow. The only limitation is that these are to be protected from sunlight and always laid underground.

In Pakistan these are manufactured according to BS 3505,1991 standard for PVC pipes.

The class of pipe is selected according to the total head (pressure) which pipe has to withstand.

\subsubsection{CLASSIFICATION OF PIPES}

\begin{tabular}{|c|c|c|c|c|c|c|}
\hline \multirow{2}{*}{ CLASS } & \multicolumn{3}{|c|}{ WORKING PRESSURE } & \multicolumn{3}{|c|}{ TEST PRESSURE } \\
\hline & Bar & $\mathrm{Kgf} / \mathrm{cm}^{2}$ & Lbf / in ${ }^{2}$ & Bar & $\mathrm{Kgf} / \mathrm{cm}^{2}$ & Lbf / in ${ }^{2}$ \\
\hline$B$ & 6 & 6.12 & 87 & 9 & 9.18 & 130 \\
\hline C & 9 & 9.18 & 130 & 14 & 13.77 & 195 \\
\hline $\mathrm{D}$ & 12 & 12.25 & 173 & 18 & 18.38 & 259 \\
\hline$E$ & 15 & 15.3 & 217 & 23 & 22.95 & 325 \\
\hline
\end{tabular}

\begin{tabular}{|c|c|c|c|c|c|c|c|c|c|}
\hline \multirow[b]{2}{*}{ 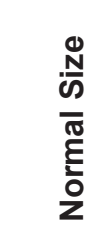 } & \multirow[b]{2}{*}{ 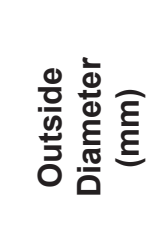 } & \multicolumn{2}{|c|}{ Class B pipe } & \multicolumn{2}{|c|}{ Class C pipe } & \multicolumn{2}{|c|}{ Class D pipe } & \multicolumn{2}{|c|}{ Class E Pipe } \\
\hline & & 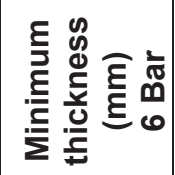 & 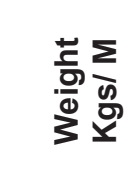 & 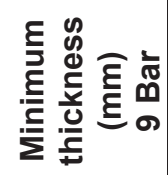 & 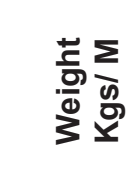 & 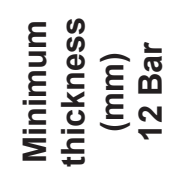 & 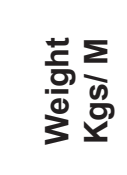 & 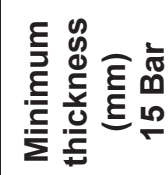 & 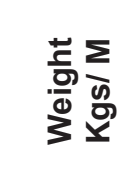 \\
\hline $3 "$ & 88.7 & 2.9 & 1.17 & 3.5 & 4.14 & 4.6 & 1.82 & - & - \\
\hline $4 "$ & 114.1 & 3.4 & 1.78 & 4.5 & 2.32 & 6.0 & 3.03 & - & - \\
\hline $5 "$ & 140.0 & 3.8 & 2.44 & 5.5 & 3.49 & - & - & - & - \\
\hline $6 "$ & 188.0 & 4.5 & 3.46 & 6.6 & 5.01 & - & - & - & - \\
\hline $8 "$ & 218.8 & 5.3 & 5.30 & 7.8 & 7.72 & - & - & - & - \\
\hline $10^{\prime \prime}$ & 272.6 & 6.6 & 8.26 & - & - & - & - & - & - \\
\hline $12 "$ & 323.4 & 7.8 & 11.55 & - & - & - & - & - & - \\
\hline
\end{tabular}

\section{$\underline{\text { TESTS }}$}

\section{Physical and chemical characteristics}

\section{Appearance}

The pipe should be reasonably round. The external and internal surface of the pipe should be smooth, clean, and reasonably free from grooving and other effects that would impair its performance in service. The ends should be cleanly cut and square with the axis of the pipe. 


\section{$\underline{\text { Heat Revision Test }}$}

Pipe should be tested at the temperature of $150^{\circ} \mathrm{C}$ for at least 15 minutes. After testing, the pipe shall show no faults, for example cracks, cavities, or blisters and pipe length should not change more than $5 \%$.

\section{Acetone Test:}

A short length of pipe shall be immersed vertically to depth of at least $25 \mathrm{~mm}$ in acetone complying with BS 509 at room temperature. The effect of the acetone on the pipe surface shall be noted after 2 hours.

After testing, sample should not show any delaminating or disintegration. Flattering and/or swelling of the pipe shall not be deemed to the constitute failure.

\section{Test for resistance to sulphuric acid}

The test specimen should be cut from the pipe and must have a surface area of $45+/-3 \mathrm{sq} . \mathrm{cm}$ or ( 7 $+/$ - $0.5 \mathrm{sq}$ inches). The test specimen should be cleaned, wiped and weighed then totally immersed in $93+/-0.5 \%$ sulphuric acid for 14 days at 55 (+/- 2) centigrade. Care should be taken to avoid gradual connection of the acid during the test due to evaporation losses etc. After rhe specified time the specimen should be removed, washed in running water for 5 minutes, wiped dry with clean cloth and re-weighed immediately.

When tested by the method, the mass of the specimen shall neither increase more than 0.32 grams nor decrease by more than $0.013 \mathrm{~g}$. The effect of the acid on the surface appearance of the specimen should be ignored.

\section{Test for opacity:}

The following apparatus will be used in this test
a) Source of light
b) Photoelectric cell
c) Spot light galvanometer

The light source and photoelectric cell shall be set up at convenient distance of daylight. The galvanometer shall be connected to the photoelectric cell and the maximum deflection registered shall be noted. A piece of pipe shall then be placed over the photoelectric cell so that one wall is interposed between the light source and cell being kept constant. The maximum deflection of the galvanometer shall again be noted. The second deflection expressed as percentage of the first shall give a measure of the visible light transmitted. When tested by this method the wall of the pipe should not transmit more than $0.2 \%$ of the visible light falling on to it. 


\subsubsection{MECHANICAL CHARACTERISTICS}

\section{Short term hydrostatic test}

A sample pipe collected from the field is checked in the laboratory at $20^{\circ} \mathrm{C}$. The sample pipe is fitted in the apparatus and appropriate internal pressure is applied within 30-40 seconds. The pipe should withstand the appropriate internal pressure for at least one hour without failure.

\section{MINIMUM ONE HOUR INTERNAL PRESSURE}

\begin{tabular}{|l|c|c|}
\hline \multirow{2}{*}{ CLASS OF PIPE } & \multicolumn{2}{|l|}{ Minimum one hour internal hydrostatic pressure } \\
\cline { 2 - 3 } & Bar & Psi \\
\hline B all sizes & 21.8 & 310 \\
\hline C all sizes & 32.4 & 470 \\
\hline D all sizes & 43.2 & 620 \\
\hline E all sizes & 54.0 & 780 \\
\hline
\end{tabular}

\section{Long term hydrostatic test}

The specimen collected as explained under procedure for short term and fitted in the same way is admitted to maintain a pressure within accuracy of (+/-) $2 \%$ throughout the test at $20^{\circ} \mathrm{c}$. For each test specimen stress shall be so chosen that first piece of pipe should expected to burst with in period of 1-10 hours and the second piece of pipe should be expected to burst with in period of 100-1000 hours. Both pieces of pipes should be tested to failure.

\section{Stress limits}

\begin{tabular}{|l|c|c|c|c|}
\hline \multirow{2}{*}{ Size of pipe } & \multicolumn{2}{|l|}{ Minimum one hour stress } & \multicolumn{2}{l|}{ Minimum 50 years stress } \\
\cline { 2 - 5 } & Bar & Psi & Bar & Psi \\
\hline Below 1" & 353 & 5124 & 206 & 2988 \\
\hline 1"- 7" & 366 & 5700 & 230 & 3340 \\
\hline 8" and above & 443 & 6430 & 360 & 3770 \\
\hline
\end{tabular}

After testing, the extrapolated 1 hour and 50 year circumferential stress levels should not be less than the appropriate values given above.

\section{Falling weight or impact test}

Falling weight or impact test is conducted at $20^{\circ} \mathrm{C}$ (room temperature). Test pieces are placed in the apparatus to sustain particular number of strokes with respective weights from height of 2 meters. 


\begin{tabular}{|c|c|c|r|}
\hline Dia Size & No of strokes & Size of test piece & \multicolumn{2}{|c|}{ Falling weight } \\
\hline $3^{\prime /}$ & 4 & 0.75 inch & $2.25 \mathrm{~kg}$ \\
\hline $4^{\prime \prime}$ & 6 & 1 inch & $2.75 \mathrm{~kg}$ \\
\hline $5^{/ /}$ & 8 & 1.25 inch & $3.25 \mathrm{~kg}$ \\
\hline
\end{tabular}

\subsubsection{GALVANIZED IRON PIPES (G.I Pipes)}

Galvanized pipes are made from steel sheets and coated through chemical process of galvanization. These pipes are very costly, shorter in life. Susceptible to corrosion, heavy in weight and offer more resistance to flow.

These pipes are only used in specific conditions where pvc pipes cannot buried or where higher pressures are to be sustained and liable to be kept on the surface.

The GI pipes are prepared according to the international standards BS and ASTM. The PSI has developed PS 1851/1987 standard for GI pipes in Pakistan.

The GI pipes are generally classified as light, medium and heavy according to BS 1387/1967 standards.

\section{Dimensions of Pipes (Light) BSS 1387/1967}

\begin{tabular}{|c|c|c|c|c|}
\hline \multirow{2}{*}{$\begin{array}{c}\text { SIZE } \\
\text { (INCHES) }\end{array}$} & \multicolumn{2}{|c|}{ OUT SIDE DIAMETER ( in) } & \multirow{2}{*}{$\begin{array}{c}\text { WALL } \\
\text { THICKNESS } \\
\text { (inches) }\end{array}$} & $\begin{array}{c}\text { WEIGHT } \\
\text { Kg/ft }\end{array}$ \\
\cline { 2 - 3 } & Maximum & Minimum & 0.116 & 1.25 \\
\hline 2 & 2.370 & 2.347 & 0.128 & 1.77 \\
\hline 2.5 & 2.991 & 2.960 & 0.128 & 2.08 \\
\hline 3 & 3.491 & 3.460 & 0.144 & 3.01 \\
\hline 4 & 4.481 & 4.450 & & \\
\hline
\end{tabular}

Dimensions of pipes (Medium) BSS 1387/1967

\begin{tabular}{|c|c|c|c|c|}
\hline \multirow{2}{*}{$\begin{array}{c}\text { SIZE } \\
\text { (INCHES) }\end{array}$} & OUT SIDE DIAMETER (inches) & \multirow{2}{*}{$\begin{array}{c}\text { WALL } \\
\text { THICKNESS } \\
\text { (inches) }\end{array}$} & $\begin{array}{c}\text { WEIGHT } \\
\text { Kg/ft }\end{array}$ \\
\cline { 2 - 3 } & Maximum & Minimum & 0.144 & 1.55 \\
\hline 2 & 2.394 & 2.354 & 0.144 & 1.99 \\
\hline 2.5 & 3.014 & 2.969 & 0.160 & 2.58 \\
\hline 3 & 3.524 & 3.469 & 0.176 & 3.69 \\
\hline 4 & 4.525 & 4.459 & 0.192 & 4.94 \\
\hline 5 & 5.534 & 5.459 & 0.192 & 5.85 \\
\hline 6 & 6.539 & 6.459 & & \\
\hline
\end{tabular}


Dimensions of pipes (Heavy) BSS 1387/1967

\begin{tabular}{|c|c|c|c|c|}
\hline \multirow{2}{*}{$\begin{array}{c}\text { SIZE } \\
\text { (INCHES) }\end{array}$} & \multicolumn{2}{|c|}{ OUT SIDE DIAMETER ( in) } & $\begin{array}{c}\text { WALL } \\
\text { THICKNESS } \\
\text { (inches) }\end{array}$ & $\begin{array}{c}\text { WEIGHT } \\
\text { Kg/ft }\end{array}$ \\
\cline { 2 - 5 } & Maximum & Minimum & 0.176 & 1.89 \\
\hline 2 & 2.394 & 2.354 & 0.176 & 2.41 \\
\hline 2.5 & 3.014 & 2.969 & 0.192 & 3.07 \\
\hline 3 & 3.524 & 3.469 & 0.212 & 4.40 \\
\hline 4 & 4.525 & 4.459 & 0.212 & 5.44 \\
\hline 5 & 5.534 & 5.459 & 0.212 & 6.49 \\
\hline 6 & 6.539 & 6.459 & & \\
\hline
\end{tabular}

$\underline{\text { Tests }}$

Pipes should be physically checked for appearance, smoothness, seeming line, and galvanization by making abrasions on the surface.

\section{Permissible variation in thickness}

Light Quality $\quad$ - $8 \%$

+ no limit

Light Quality $\quad-10 \%$

+ no limit

Light Quality $\quad-10 \%$

+ no limit

Permissible variation in Weight

Single tube $20 \mathrm{ft}$

$-8 \%+10 \%$

Lot of $1000 \mathrm{ft} \&$ over

$-4 \%+4 \%$

\section{$\underline{\text { Hydrostatic pressure test }}$}

Light

700 Psi

Medium

700 psi

Heavy

700 Psi 


\subsubsection{POLYETHYLENE PIPES}

The extrusion compound used for the PE pipe is manufactured from mixture of polyethylene which may include copolymers of ethylene and higher olefins. It also includes antioxidants and carbon black uniformly dispersed.

There are several ISO standards defining the material and are as given below.

ISO 12162 / 1995, ISO 8779/ 2001and ISO 8796/ 1989

Two types of polyethylene pipes are available in the market the low density polyethylene pipe (LDPE) and high density polyethylene pipe (HDPE). The LDPE pipe is used for drip irrigation schemes and is specified by SABS 533 Part 1:1982. It is used both on ground and underground installations. In some countries, HDPE pipe is used as secondary and manifold lines for drip irrigation systems.

There are several types of LDPE and HDPE pipes confirming the SABS standards.

\subsubsection{DRIP TAPE}

One of the most interesting development with localized irrigation is the introduction of what is commonly known as drip tape. The ANSI/ASAE S553 MAROI standard provide the specifications.

\subsection{PIPE HYDRAULICS}

\subsubsection{Friction Loss}

Head loss results from friction between the pipe walls and water as it flows through the system. Various fittings such as turns, bends, expansions and contractions, etc. along the way, will increase the head loss.

Head loss in a pipe system is affected by the following:

Length

Type of material

Inside diameter

Flow rate through pipe

Type of liquid flowing through the pipe

There are two types of friction losses that will occur while water will be flowing through the pipe system of the pressurized irrigation system namely major losses and minor losses. Major head losses result as water moves through straight pipes. Minor losses are created when water flows through bends and transitions. 


\subsubsection{Calculation of Friction Loss}

Different methods and equations developed i.e., Hazen-Williams, Darcy-Weisbach, and Watters \& Keller can be used for the calculation of head losses through the pipes and fittings. This manual will cover only two of these methods namely; Hazen-Williams and Watters \& Kellers due to their simplicity.

\subsubsection{Hazen-Williams Equation}

Empirical formulae are sometimes used to calculate the approximate head loss in a pipe when water is flowing and the flow is turbulent. Prior to the availability of personal computers, HazenWilliams formula was very popular with engineers because of the relatively simple calculations required. Unfortunately, the results depend upon the value of the Friction Factor "C" which must be used with the formula and this can vary from around 80 up to 130 and higher, depending on the pipe type, pipe size and the water velocity. The empirical form of the Hazen Williams formula is:

$$
\mathrm{J}=\mathrm{hf} / \mathrm{L} / 100=\mathrm{K}(\mathrm{Q} / \mathrm{C})^{1.852} \times \mathrm{D}^{-4.8655}
$$

Where:

hf $\quad=\quad$ Head loss due to pipe friction, $\mathrm{m}(\mathrm{ft})$

$\mathrm{J}=\quad$ Head loss gradient, $\mathrm{m} / 100 \mathrm{~m}(\mathrm{ft} / 100 \mathrm{ft})$

$\mathrm{K}=\quad$ Conversion constant, $1.212 \times 10^{12}$ for metric units (1050 for English units)

$\mathrm{L}=\quad$ Length of pipe, $\mathrm{m}(\mathrm{ft})$

$\mathrm{C}=$ Friction coefficient, which is a function of pipe material characteristics

$\mathrm{Q} \quad=\quad$ Flow rate in the pipe, $\mathrm{L} / \mathrm{s}$ (gpm)

$\mathrm{D}=\quad$ Inside diameter of the pipe, $\mathrm{mm}$ (in)

The empirical nature of the friction factor C makes the 'Hazen-Williams' formula unsuitable for accurate prediction of head loss. The results are only valid for fluids which have a kinematics viscosity of 1.13 centistokes, where the fluid velocity is less than 10 feet per sec and the pipe size is greater than 2" diameter. Water at $60^{\circ} \mathrm{F}\left(15.5^{\circ} \mathrm{C}\right)$ has a kinematics viscosity of 1.13 centistokes.

Table 5.1 Typical values of $\mathbf{C}$ for various types of pipe

\begin{tabular}{|l|c|}
\hline Asbestos Cement & 140 \\
\hline Plastic pipe & 140 \\
\hline PVC pipe & 150 \\
\hline General smooth pipes & 140 \\
\hline Galvanized Steel pipe & 135 \\
\hline Aluminum & 130 \\
\hline
\end{tabular}

Hazen-Williams formula provides more accurate results for pipe diameters $75 \mathrm{~mm}$ ( 3 inches) or larger, however, for small diameter pipes this equation underestimates the results. 
Example: Determine head loss through $100 \mathrm{~mm}$ (inside diameter $99 \mathrm{~mm}$ ) Aluminum pipe, $396 \mathrm{~m}$ long pipe with 990 litre/minute $(16.5 \mathrm{~L} / \mathrm{s})$.

Select C value from Table 6.1 and enter values in the equation.

$\begin{array}{lll}\mathrm{J} & = & 1.21 \times 10^{12}(16.5 / 130)^{1.852} \times(99)^{-4.8655} \\ \mathrm{~J} & = & 5.06 \mathrm{~m} / 100 \mathrm{~m} \\ \mathrm{Hf} & = & 5.06 / 100 \times 396=\end{array}$

\subsubsection{Watters \& Keller Equation}

Watters \& Kellers developed a simplified equation for use with smooth plastic pipes and hoses less than $125 \mathrm{~mm}$ (5 inches).

Where

$$
\mathrm{J}=100 \mathrm{hf} / \mathrm{L}=\mathrm{KQ}^{1.75} / \mathrm{D}^{1.75}
$$

$\mathrm{K}=\quad$ Conversion constant, $7.89 \times 10^{7}$ for metric units $(0.133$ for English units $)$

For large plastic pipe, where diameter is greater than $125 \mathrm{~mm}$ (5 in), the friction head loss gradient can be approximated by:

$$
\mathrm{J}=100 \mathrm{hf} / \mathrm{L} \quad=\quad \mathrm{KQ}^{1.83} / \mathrm{D}^{4.83} \quad \text { ) }
$$

Where

$\mathrm{K}=\quad$ Conversion constant, $9.58 \times 10^{7}$ for metric units ( 0.133 for English units)

\subsubsection{VELOCITY OF FLOW}

Velocity of water flowing through pipes can be calculated using the following equation

$$
\mathbf{V}=\mathrm{KQ} /\left(\mathrm{D}^{2}\right)
$$

Where

$\mathrm{V}=\quad$ velocity of flow in pipe, $\mathrm{m} / \mathrm{s}(\mathrm{ft} / \mathrm{s})$

$\mathrm{Q} \quad=\quad$ Flow rate, L/s $(\mathrm{gpm})$

$\mathrm{K}=$ Conversion factor, 1273 for metric unit (0.4085 for English units)

$\mathrm{D}=\quad$ Inside diameter of pipe, $\mathrm{mm}$ (in)

Example: Determine velocity of water through pipe (inside diameter 10.226 in) flowing at1200 gpm 
Using Equation No. 5.4

$\begin{array}{lll}\mathbf{V} & = & \left.0.4085 \times 1200 /(10.226)^{2}\right] \\ V & = & 4.7 \mathrm{ft} / \mathrm{s}\end{array}$

Velocity in sub-mainlines may be kept under $2.5 \mathrm{~m} / \mathrm{s}$.

\begin{tabular}{|c|c|c|c|c|c|c|c|c|c|c|}
\hline \multirow{3}{*}{$\begin{array}{c}\text { Nominal } \\
\text { Size }\end{array}$} & \multirow{2}{*}{\multicolumn{2}{|c|}{$\begin{array}{l}\text { Mean Outside } \\
\text { Diameter }\end{array}$}} & \multicolumn{8}{|c|}{ Wall Thickness (S) } \\
\hline & & & \multicolumn{2}{|c|}{$\begin{array}{l}\text { Class B } 6 \text { Bar } \\
(200 \mathrm{ft} \text { head })\end{array}$} & \multicolumn{2}{|c|}{$\begin{array}{l}\text { Class C } 9 \text { Bar } \\
(300 \mathrm{ft} \text { head })\end{array}$} & \multicolumn{2}{|c|}{$\begin{array}{l}\text { Class D } 12 \\
\text { Bar (400 ft } \\
\text { head) }\end{array}$} & \multicolumn{2}{|c|}{$\begin{array}{c}\text { Class E } 15 \\
\text { Bar (500 ft } \\
\text { head) }\end{array}$} \\
\hline & $\min$ & $\max$ & $\min$ & $\max$ & $\min$ & $\max$ & $\min$ & $\max$ & $\min$ & $\max$ \\
\hline $1 / 2$ & 21.2 & 21.5 & & & & & & & 1.7 & 2.1 \\
\hline $3 / 4$ & 26.6 & 26.9 & & & & & & & 1.9 & 2.5 \\
\hline 1 & 33.4 & 33.7 & & & & & & & 2.2 & 2.7 \\
\hline $1 \frac{1}{4}$ & 42.1 & 42.4 & & & & & 2.2 & 2.7 & 2.7 & 3.2 \\
\hline $1 \frac{1}{2}$ & 48.1 & 48.4 & & & & & 2.5 & 3.0 & 3.1 & 3.7 \\
\hline 2 & 60.2 & 60.5 & & & 2.5 & 3.0 & 3.1 & 3.7 & 3.9 & 4.5 \\
\hline $21 / 2$ & 75.0 & 75.3 & & & 3.0 & 3.5 & 3.9 & 4.5 & 4.8 & 5.5 \\
\hline 3 & 88.7 & 89.1 & 2.9 & 3.4 & 3.5 & 4.1 & 4.6 & 5.3 & 5.7 & 6.6 \\
\hline 4 & 114.1 & 114.5 & 3.4 & 4.0 & 4.5 & 5.2 & 6.0 & 6.9 & 7.3 & 8.4 \\
\hline 5 & 140.0 & 140.4 & 3.8 & 4.4 & 5.5 & 6.4 & 7.3 & 8.4 & 9.0 & 10.4 \\
\hline 6 & 168.0 & 168.5 & 4.5 & 5.2 & 6.6 & 7.6 & 8.8 & 10.2 & 10.8 & 12.5 \\
\hline 8 & 218.8 & 219.4 & 5.3 & 6.1 & 7.8 & 9.0 & 10.3 & 11.9 & 12.4 & 14.5 \\
\hline 10 & 272.6 & 272.4 & 6.6 & 7.6 & 9.7 & 11.2 & 12.8 & 14.8 & 15.7 & 18.1 \\
\hline 12 & 323.4 & 324.3 & 7.8 & 9.0 & 11.5 & 13.3 & 15.2 & 17.5 & 18.7 & 21.6 \\
\hline 14 & 355.0 & 356.0 & 8.5 & 9.8 & 12.6 & 14.5 & 16.7 & 19.2 & 20.5 & 23.6 \\
\hline 16 & 405.9 & 406.9 & 9.7 & 11.2 & 14.5 & 16.7 & 19.0 & 21.9 & 23.4 & 27.0 \\
\hline 18 & 456.7 & 457.7 & 11.0 & 12.7 & 16.3 & 18.8 & 21.4 & 24.6 & - & - \\
\hline 20 & 507.5 & 508.5 & 12.2 & 14.1 & 18.1 & 20.9 & - & - & - & - \\
\hline 24 & 609.1 & 610.1 & 14.6 & 16.8 & 21.7 & 25.0 & - & - & - & - \\
\hline
\end{tabular}

\subsubsection{Selection and Design of Lateral Line}

Laterals are available in different sizes i.e. $12 \mathrm{~mm}, 16 \mathrm{~mm}$ and $20 \mathrm{~mm}$. Head loss in the lateral length between the first and last emitter should not exceed by $20 \%$ of the head available at the first emitter to keep flow variation within $10 \%$ so as $90 \%$ of application uniformity can be achieved.

The design of lateral pipe involves selection of required pipe size for a given length which can require quantity of water to the plant. This is the most important component of the system as large amount of pipe per unit of land is required and the pipe cost is such that system is economically viable.

In designing the lateral, the discharge and operating pressure at emitters are required to be known and accordingly, the allowable pressure drop can be determined by the same formula as the main line. The total friction head loss in lateral can be calculated by multiplying the head loss over the total length by a factor $F$ given in Table 6.2.

Lateral Head loss $=\mathrm{hf} \times \mathrm{F}$ 
Criteria: Allowable pressure drop in sub-mainline and laterals depends upon the operating pressure required at emitters. The pressure difference between the proximate and distant point along the supply line should not exceed $20 \%$ which will keep the variation of discharge within $10 \%$ of its value at the first emitter. The emitter operating pressure is usually $10 \mathrm{~m}$, therefore, the maximum allowable head loss in a lateral should be less than $20 \%$ of emitter operating pressure i.e. $2 \mathrm{~m}$.

Table 6.2 Reduction Coefficient 'F' for Multiple Outlet Pipeline Friction Loss

\begin{tabular}{|c|c|c|c|}
\hline No. of outlets & $\mathbf{F}$ & No. of outlets & $\mathbf{F}$ \\
\hline 1 & 1 & 8 & 0.42 \\
\hline 2 & 0.65 & 10 to 11 & 0.41 \\
\hline 3 & 0.55 & 12 to 15 & 0.40 \\
\hline 4 & 0.50 & 16 to 20 & 0.39 \\
\hline 5 & 0.47 & 21 to 30 & 0.38 \\
\hline 6 & 0.45 & 21 to 37 & 0.37 \\
\hline 7 & 0.44 & 38 to 70 & 0.36 \\
\hline
\end{tabular}

\section{Example Lateral Design:}

Assume:

Flow per dripper $=8 \mathrm{LPH}$

Dripper to dripper spacing (average) $=2.30 \mathrm{~m}$

Lateral diameter $=16 \mathrm{~mm}$ (inside diameter $=14.2 \mathrm{~m}$ )

What should be maximum permissible length of lateral to have a head loss of $2 \mathrm{~m}=$ ?

Solution:

\begin{tabular}{|l|c|c|}
\hline Particulars & Unit & H.Zone1 \\
\hline Lateral Length & $\mathrm{m}$ & $\mathbf{1 0}$ \\
\hline Inside diameter & $\mathrm{mm}$ & $\mathrm{PE}$ \\
\hline Pipe material & & 150 \\
\hline Pipe friction coefficient & $\mathrm{m}$ & $\mathbf{2 . 0}$ \\
\hline Emitter spacing & Nos. & $\mathbf{2 7}$ \\
\hline No. of emitters & $\mathrm{LPH}$ & $\mathbf{8}$ \\
\hline Emitter flow rate & $\mathrm{LPH}$ & $\mathbf{2 1 6}$ \\
\hline Lateral flow rate & - & $\mathbf{0 . 3 6}$ \\
\hline Factor for multiple outlet & $\mathrm{m}$ & $\mathbf{0}$ \\
\hline Fittings loss for emitters & $\mathrm{m} / 100 \mathrm{~m}$ & $\mathbf{3 . 3}$ \\
\hline Head loss (Watter \& Keller) & $\mathrm{m} / 100 \mathrm{~m}$ & $\mathbf{2 . 7}$ \\
\hline Head loss (Hazzen Willam) & $\mathrm{m}$ & $\mathbf{1 . 8 7}$ \\
\hline Total lateral head loss, $\mathrm{h}_{\mathrm{f}}$ & $\mathrm{m} / \mathrm{sec}$ & $\mathbf{0 . 7 3}$ \\
\hline Velocity & & \\
\hline
\end{tabular}

\begin{tabular}{|l|c|}
\hline Emitter operating pressure $=$ & 10 \\
\hline Required lateral head loss $\mathbf{( 2 0} \%)=$ & 2 \\
\hline Calculated lateral head loss $=$ & 1.87 \\
\hline & OK \\
\hline
\end{tabular}


Lateral is selected

\section{Example Lateral Design:}

Assume:

Flow per dripper $=8 \mathrm{LPH}$

Dripper to dripper spacing (average) $=2.30 \mathrm{~m}$

Lateral diameter $=16 \mathrm{~mm}$ (inside diameter $=14.2 \mathrm{~m})$

What should be maximum permissible length of lateral to have a head loss of $2 \mathrm{~m}=$ ?

Solution:

\begin{tabular}{|l|c|c|}
\hline Lateral Length & $\mathrm{M}$ & 109 \\
\hline Inside diameter & $\mathrm{Mm}$ & 14.2 \\
\hline Pipe material & & $\mathrm{PE}$ \\
\hline Pipe friction coefficient & $\mathrm{M}$ & 150 \\
\hline Emitter spacing & $\mathrm{Nos}$ & 2.3 \\
\hline No. of emitters & $\mathrm{LPH}$ & 47 \\
\hline Emitter flow rate & $\mathrm{LPH}$ & $\mathbf{8}$ \\
\hline Lateral flow rate & - & 376 \\
\hline Factor for multiple outlet & $\mathrm{M}$ & 0.36 \\
\hline Fittings loss for emitters & $\mathrm{m} / 100 \mathrm{~m}$ & 0 \\
\hline Head loss (Watter \& Keller) & $\mathrm{m} / 100 \mathrm{~m}$ & 1.8 \\
\hline Head loss (Hazzen Willam) & $\mathrm{M}$ & 1.5 \\
\hline Total lateral head loss, $\mathrm{h}_{\mathrm{f}}$ & $\mathrm{m} / \mathrm{sec}$ & 2.00 \\
\hline Velocity & & $\mathbf{0 . 6 6}$ \\
\hline
\end{tabular}

\begin{tabular}{|l|c|}
\hline Emitter operating pressure $=$ & 10 \\
\hline Required lateral head loss $\mathbf{( 2 0} \%)=$ & 2 \\
\hline Calculated lateral head loss $=$ & 2.00 \\
\hline & OK \\
\hline
\end{tabular}

Lateral is selected

\subsubsection{DESIGN OF SUB-MAIN LINE}

On the manifolds, whether these pipelines are the sub-main or the mains as well, a number of laterals are fed simultaneously. The flow of the line is distributed en route, as in the laterals with the emitters. Consequently, when computing the friction losses.

The mains, sub-main and all hydrants are selected in such sizes that the friction losses do not exceed approximately 15 percent of the total dynamic head required at the beginning of the system's piped network. On level ground, these friction losses amount to about 20 percent of the emitter's fixed operating pressure. This is a practical rule for all pressurized systems to achieve uniform pressure conditions and water distribution at any point of the systems. The above figure 
should not be confused with or related in any way to the maximum permissible friction losses along the laterals.

Criteria:

- Maximum Water Velocity in sub-main and mainline $=1.5 \mathrm{~m} / \mathrm{s}$

- Maximum Frictional Losses in sub-main $=2 \mathrm{~m}$

- Maximum Frictional Losses in mainline $=20 \mathrm{~m}$ per $1000 \mathrm{~m}$ length

- Hazen Williams Equation for Frictional Losses

Assume:

Flow per dripper $=4 \mathrm{LPH}$

Dripper to dripper spacing $=0.5 \mathrm{~m}$

Lateral to lateral spacing $=1.5 \mathrm{~m}$

Sub-main diameter $=2$ inch $=63 \mathrm{~mm}$ (inside diameter $=59.8 \mathrm{~mm}$ )

What should be sub-main maximum permissible length to have a head loss of $2 \mathrm{~m}=$ ?

\begin{tabular}{|l|c|c|}
\hline Particulars & Unit & H.Zone1 \\
\hline Sub-Mainline Length & $\mathrm{m}$ & 41 \\
\hline Inside diameter & $\mathrm{mm}$ & 75 \\
\hline Pipe material & & PVC \\
\hline Pipe friction coefficient & $\mathrm{m}$ & 150 \\
\hline Lateral spacing & $\mathrm{Nos}$. & 0.75 \\
\hline No. of laterals operating & $\mathrm{LPH}$ & 55 \\
\hline Lateral flow rate & $\mathrm{LPH}$ & $\mathbf{3 6 8}$ \\
\hline Sub-mainline flow rate & - & $\mathbf{2 0 1 1 7}$ \\
\hline Factor for multiple outlet & $\mathrm{m} / 100 \mathrm{~m}$ & $\mathbf{0 . 3 6}$ \\
\hline Head loss gradient (Watter \& Keller) & $\mathrm{m} / 100 \mathrm{~m}$ & $\mathbf{0 . 7 2}$ \\
\hline Head loss gradient (Hazzen Willam) & $\mathrm{m}$ & $\mathbf{0 . 7 3}$ \\
\hline Total head loss, $\mathrm{h}_{\mathrm{f}}$ & $\mathrm{m} / \mathrm{s}$ & $\mathbf{0 . 3}$ \\
\hline Velocity & & $\mathbf{1 . 2 7}$ \\
\hline
\end{tabular}

Sub-main is selected

Assume:

Flow per dripper $=8 \mathrm{LPH}$

Dripper to dripper spacing $=0.5 \mathrm{~m}$

Lateral to lateral spacing $=1.5 \mathrm{~m}$

Sub-main diameter $=2$ inch $=63 \mathrm{~mm}$ (inside diameter $=59.8 \mathrm{~mm}$ )

What should be sub-main maximum permissible length to have a head loss of $2 \mathrm{~m}=$ ? 


\begin{tabular}{|l|l|c|}
\hline Particulars & \multicolumn{1}{|c|}{ Unit } & H.Zone1 \\
\hline Sub-Mainline Length & $\mathrm{m}$ & 95 \\
\hline Inside diameter & $\mathrm{mm}$ & 71.4 \\
\hline Pipe material & & PVC \\
\hline Pipe friction coefficient & & 150 \\
\hline Lateral spacing & $\mathrm{m}$ & 2.29 \\
\hline No. of laterals operating & Nos. & 83 \\
\hline Lateral flow rate & LPH & 256 \\
\hline Sub-mainline flow rate & LPH & 21240 \\
\hline Factor for multiple outlet & - & 0.36 \\
\hline Head loss gradient (Watter \& Keller) & $\mathrm{m} / 100 \mathrm{~m}$ & $\mathbf{0 . 9 9}$ \\
\hline Head loss gradient (Hazzen Willam) & $\mathrm{m} / 100 \mathrm{~m}$ & 1.02 \\
\hline Total head loss, $\mathrm{h}_{\mathrm{f}}$ & $\mathrm{m}$ & 1.0 \\
\hline Velocity & $\mathrm{m} / \mathrm{s}$ & 1.47 \\
\hline
\end{tabular}

\subsubsection{Selection and Design of mainline}

\section{Criteria:}

- Should be selected based on the quantity of water, length, elevation of ground, velocity, cost etc.

- Permissible velocity: Less than $1.5 \mathrm{~m} / \mathrm{s}$

- Frictional losses: Less than $2 \mathrm{~m} / 100 \mathrm{~m}$

- Economics: Less initial and annual operating cost

- Elevation and Class of Pipe: Pipe class affects the system cost, use appropriate pressure class pipe and try to lay the pipe at same elevation

- Control measures: Pressure relief valves at appropriate location i.e., where elevation changes

\section{Example}

Assume

Mainline length $=156 \mathrm{~m}$

Diameter $=4$ inch $=150 \mathrm{~mm}$ (inside diameter $=85.6 \mathrm{~mm}$ )

Designed discharge $=23492 \mathrm{lps}$

Material is PVC $(\mathrm{C}=150)$ 
Calculate friction loss and check velocity

\begin{tabular}{|c|c|c|}
\hline \multirow{2}{*}{ Particular } & \multirow{2}{*}{ Unit } & Section \\
\hline & & 1 \\
\hline Length & $\mathrm{m}$ & 156 \\
\hline Inside diameter & $\mathrm{mm}$ & 85.6 \\
\hline Pipe material & & PVC \\
\hline Pipe friction coefficient & & 150 \\
\hline Design capacity & LPH & 23492 \\
\hline Head loss gradient (Watter \& Keller) & $\mathrm{m} / 100 \mathrm{~m}$ & 1.39 \\
\hline Head loss gradient (Hazzen Willam) & $\mathrm{m} / 100 \mathrm{~m}$ & 1.42 \\
\hline Mainline fittings losses & $\mathrm{m}$ & 0 \\
\hline Flow velocity & $\mathrm{m} / \mathrm{s}$ & 1.13 \\
\hline Total mainline head loss & $\mathrm{m}$ & 2.21 \\
\hline
\end{tabular}

\section{Main line is selected}

\section{Example 2}

\begin{tabular}{|l|l|c|}
\hline \multirow{2}{*}{ Particular } & \multirow{2}{*}{ Unit } & Section \\
\cline { 3 - 3 } & $\mathrm{m}$ & $\mathbf{1}$ \\
\hline Length & $\mathrm{mm}$ & 213 \\
\hline Inside diameter & & PVC \\
\hline Pipe material & & 150 \\
\hline Pipe friction coefficient & LPH & 23253 \\
\hline Design capacity & $\mathrm{m} / 100 \mathrm{~m}$ & 1.46 \\
\hline Head loss gradient (Watter \& Keller) & & 1.49 \\
\hline Head loss gradient (Hazzen Willam) & $\mathrm{m} / 100 \mathrm{~m}$ & 0 \\
\hline Mainline fittings losses & $\mathrm{m}$ & $\mathbf{1 . 1 6}$ \\
\hline Flow velocity & $\mathrm{m} / \mathrm{s}$ & 3.17 \\
\hline Total mainline head loss & $\mathrm{m}$ & \\
\hline
\end{tabular}

\subsubsection{HEAD LOSS THROUGH FITTINGS}

The three conventional methods for computing the additional pressure-head losses from special equipment, valves, pipe and fittings are: (1) graphing friction loss vs. flow rate, (2) expressing the added pressure head loss as the length of pipe (of the same diameter) that would give the same loss, and (3) expressing the loss in terms of a velocity head coefficient. Following Equation $\mathbf{5 . 5}$ can be used for computing friction head loss caused by a specific fitting (he), feet.

$$
\mathrm{h}_{\mathrm{e}}=\mathrm{K}_{\mathrm{f}} \frac{\mathrm{V}^{2}}{2 \mathrm{~g}}
$$


Where;

$\mathrm{Kf}=$ friction head-loss coefficient for a specific fitting.

$V^{2} / 2 g$ = velocity head, which is the energy head from the velocity of flow, feet or $m$.

Kf values should be supplied by manufacturers or taken from handbooks on hydraulics. Usually the losses attributed to standard pipe fittings are small and can be grouped in a miscellaneous friction-loss or safety factor.

\subsubsection{SELECTION OF FILTERS AND THEIR HEAD LOSS}

There are four kinds of filters used in different combination depending upon source of water

- Hydrocylone Filter $(\mathrm{H})$

- Sand Media (S)

- $\quad$ Disc Filter (D)

- Screen filters

Application:

- $\mathrm{H}+\mathrm{S}+\mathrm{D}=$ When Water quality is very bad, contains silt particles

- $\mathrm{S}+\mathrm{D}=$ Open Well, Tank, Pond, Reservoir, Canal

- $\mathrm{H}+\mathrm{D}=$ Borewell

- $\quad \mathrm{D}$ (only) $=$ When water is very clean

To prevent solid particles in the water from penetrating the irrigation system and clogging the drippers

- Source of water

- Type, size and concentration of physical impurities

- Type of irrigation system

- Ease of handling, cleaning, maintenance and repairing

- Filtration media and frictional losses

- Economical investment, maintenance and power cost 
Sand Media Filter

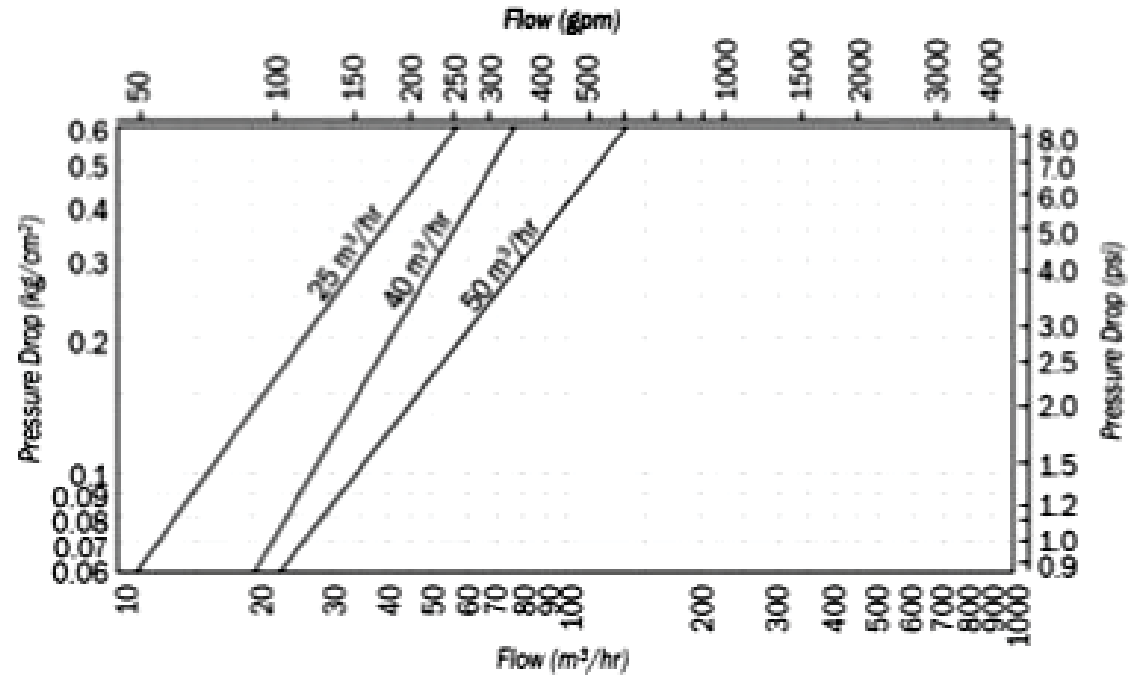

Hydrocyclone Filter

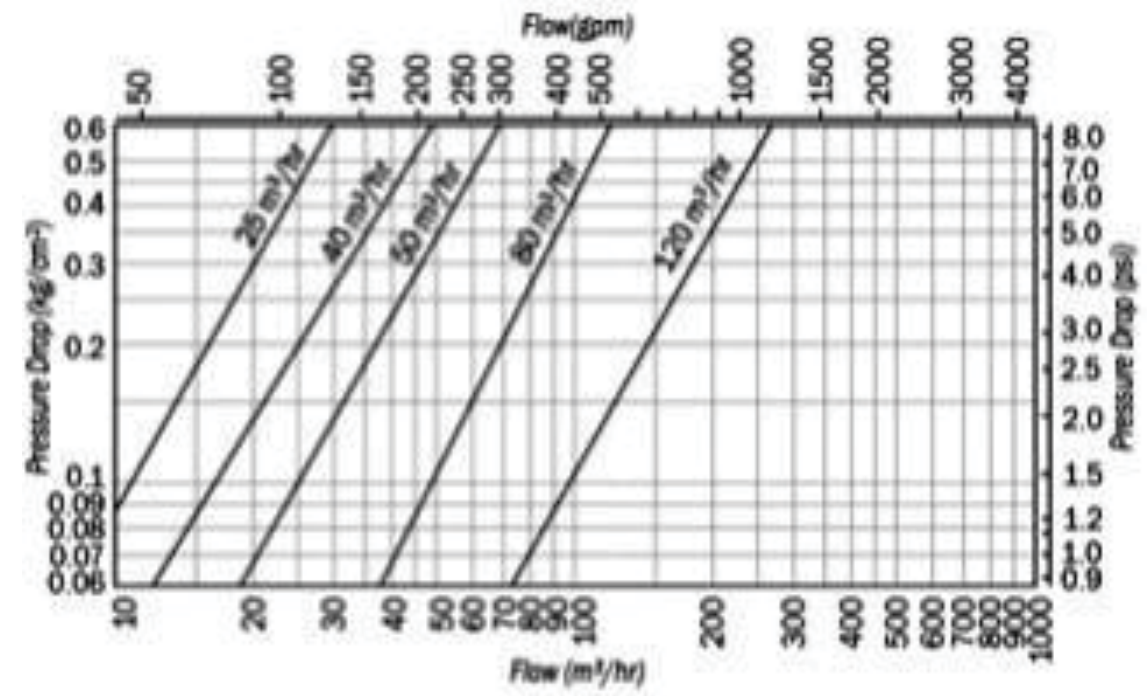

Disc Filter

Flow (gpm)

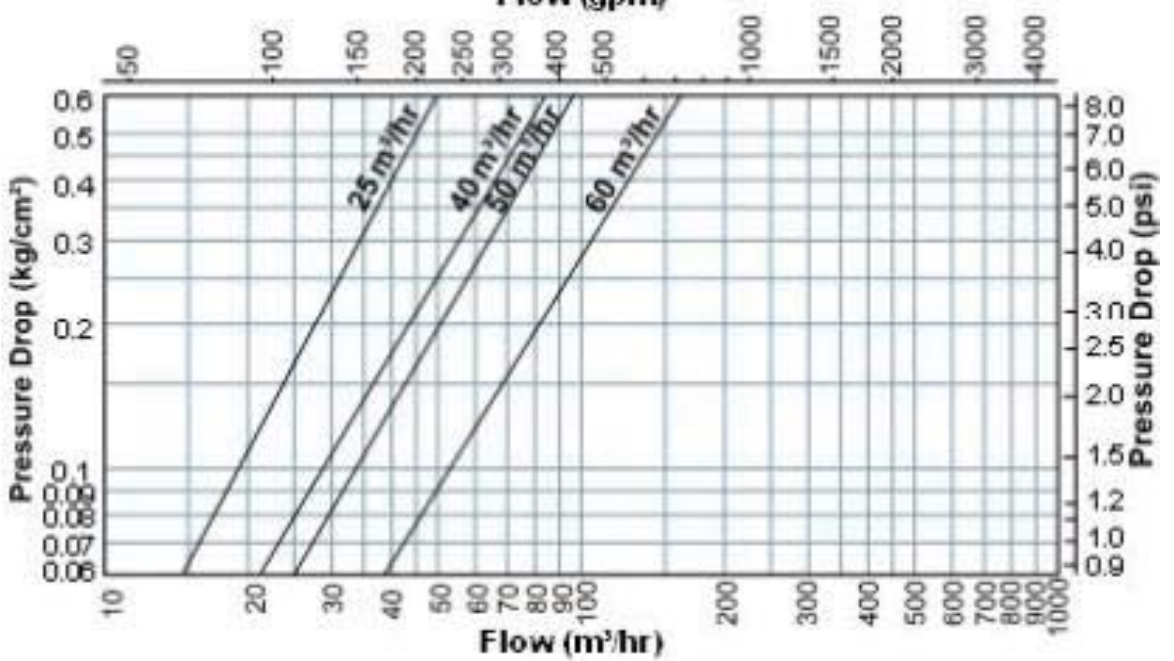


WATER QUALITY

(Factor for drip irrigation)

\begin{tabular}{|c|c|c|}
\hline Physical (Suspended solids) & Chemical (Precipitation) & Biological (Bacteria \& Algae) \\
\hline $\begin{array}{c}\text { Inorganic particles } \\
\text { Sand } \\
\text { Silt } \\
\text { Clay } \\
\text { Plastics }\end{array}$ & $\begin{array}{c}\text { Calcium or Magnesium } \\
\text { carbonates, Calcium Sulphates }\end{array}$ & $\begin{array}{l}\text { Filaments } \\
\text { Slime }\end{array}$ \\
\hline \multirow[t]{2}{*}{$\begin{array}{l}\text { Organic Particles } \\
\text { Aquatic plants } \\
\text { Aquatic animals } \\
\text { Bacteria }\end{array}$} & $\begin{array}{l}\text { Heavy metals, oxides, } \\
\text { hydrocides, carobonates, } \\
\text { silicates and sulphides }\end{array}$ & $\begin{array}{c}\text { Microbial decomposition } \\
\text { Iron } \\
\text { Sulphur } \\
\text { Manganese }\end{array}$ \\
\hline & $\begin{array}{l}\text { Oil or other lubricant fertilizers } \\
\text { Phosphate } \\
\text { Aqueous Ammonia } \\
\text { Iron, Copper, Zinc, Manganese }\end{array}$ & \\
\hline
\end{tabular}

WATER QUALITY CRITERIA FOR EMITTER CLOGGING

\begin{tabular}{|c|c|c|c|}
\hline \multirow{2}{*}{ Type of Problem } & \multicolumn{3}{|c|}{ Clogging Hazard } \\
\hline & Minor & Moderate & Severe \\
\hline $\begin{array}{c}\text { Physical } \\
\text { (Suspended solidsa }\end{array}$ & 50 & $50-100$ & $>100$ \\
\hline $\begin{array}{c}\text { Chemical } \\
\text { pH } \\
\text { Dissolved Solidsa } \\
\text { Manganesea } \\
\text { Total Irona } \\
\text { Hydrogen Sulphides a }\end{array}$ & $\begin{array}{l}7.0 \\
500 \\
0.1 \\
0.2 \\
0.2\end{array}$ & $\begin{array}{c}7.0-8.0 \\
500-2000 \\
0.1-1.5 \\
0.2-1.5 \\
0.2-2.0\end{array}$ & $\begin{array}{cc}> & 8.0 \\
> & 2000 \\
> & 1.5 \\
> & 1.5 \\
> & 2.0\end{array}$ \\
\hline $\begin{array}{c}\text { Biological } \\
\text { Bacterial Population b }\end{array}$ & 10,000 & $10,000-50,000$ & $>50,000$ \\
\hline
\end{tabular}
(a: ppm
b: number/mL)

\section{Selection of Valves}

- The Valve can take upto $40 \%$ more flow than the pipe flow rate. Hence the Valve size can be one size less than the Pipeline Size

- The Friction loss in the Valve will be upto $2 \mathrm{~m}$ approx. 


\subsubsection{Total Dynamic Head}

Total Dynamic head is the total pressure required to provide the required pressure at the end of the last emitter. It is calculated as follows

Total Dynamic Head = $\quad=\quad$ suction head + delivery head + filter losses + mainline losses + sub-mainline losses + lateral loss + Fertigation system loss + fitting loss + - elevation difference + operating pressure

\begin{tabular}{|l|l|c|}
\hline Emitter operating pressure & $\mathrm{m}$ & 10 \\
\hline Elevation difference & $\mathrm{m}$ & 0 \\
\hline Total Head Loss (Pipe network) & $\mathrm{m}$ & 4.18 \\
\hline Fitting loss Lateral & $\mathrm{m}$ & 0.1 \\
\hline Fitting loss Mainline & $\mathrm{m}$ & 0.6 \\
\hline Fitting loss Sub-mainline & $\mathrm{m}$ & 0.6 \\
\hline Fitting loss Head unit & $\mathrm{m}$ & 0.7 \\
\hline Head loss in filters & $\mathrm{m}$ & 12 \\
\hline Head loss in fertigation system & $\mathrm{m}$ & 4 \\
\hline Head loss in flow meter & $\mathrm{m}$ & 1 \\
\hline Field fitting losses & $\mathrm{m}$ & 0 \\
\hline Miscellaneous head loss & $\mathrm{m}$ & 2 \\
\hline Pumping lift & $\mathrm{m}$ & 2 \\
\hline Total Dynamic Head & $\mathrm{m}$ & 37.18 \\
\hline
\end{tabular}

Total pipe network HL $<25 \%$ of Total Dynamic Head

Main line and sub mainline head loss may be less than $1 \mathrm{~m} / 100 \mathrm{~m}$

\begin{tabular}{|l|c|c|c|}
\hline Emitter operating pressure & $M$ & 10 & \\
\hline Elevation difference & $\mathrm{M}$ & 0 & \\
\hline Headloss in lateral & $\mathrm{M}$ & 0.7 & \\
\hline Headloss in Submain & $\mathrm{M}$ & 1.1 & 1.1 \\
\hline Head Loss (Main) & $\mathrm{M}$ & 3.17 & 3.17 \\
\hline Headloss in valves & $\mathrm{M}$ & 2 & 2 \\
\hline Fitting loss Lateral & $\mathrm{M}$ & 1.1 & 2 \\
\hline Fitting loss Mainline & $\mathrm{M}$ & 2 & \\
\hline Fitting loss Sub-mainline & $\mathrm{M}$ & 0 & \\
\hline Fitting loss Head unit & $\mathrm{M}$ & 0 & \\
\hline Head loss in filters(Primary) & $\mathrm{M}$ & 4 & \\
\hline Head loss in filters(secondry) & $\mathrm{M}$ & 4 & \\
\hline Head loss in fertigation system & $\mathrm{M}$ & 5 & \\
\hline Head loss in flow meter & $\mathrm{M}$ & 0 & \\
\hline Field fitting losses & $\mathrm{M}$ & 0 & \\
\hline Safty equipment headloss & $\mathrm{M}$ & 2 & \\
\hline Miscellaneous head loss & $\mathrm{M}$ & 0 & \\
\hline Suction head & $\mathrm{M}$ & 1 & \\
\hline Delivery head & $\mathrm{M}$ & 1 & \\
\hline Pumping lift & $\mathrm{M}$ & 0 & \\
\hline Total Dynamic Head & $\mathrm{M}$ & 37.07 & 9.37 \\
\hline
\end{tabular}


Total pipe network headloss/Total Dynamic Head $(\%)=$

\section{Total pipe network HL $<25 \%$ of Total Dynamic Head}

Lateral head loss may be less than $20 \%$ of the emitter operating pressure

Flow velocity less than $1.5 \mathrm{~m} / \mathrm{sec}$

Main line and sub mainline head loss may be less than $1 \mathrm{~m} / 100 \mathrm{~m}$

\subsubsection{Calculation of Required Horsepower}

Pumps and lifting/propelling devices are often classified on the basis of the mechanical principle used to lift the water: direct lift, displacement, creating a velocity head, using the buoyancy of a gas or gravity. Most categories sub-divide into further classifications "reciprocating/cyclic" and "rotary". Virtually all water lifting devices can best be characterized for practical purposes by measuring their output at different heads and speeds. Normally the performance of a pump is presented on a graph of head versus flow (an H-Q graph) and in most cases curves can be defined for the relationship between $\mathrm{H}$ and $\mathrm{Q}$ at different speeds of operation. Invariably there is a certain head, flow and speed of operation that represents the optimum efficiency of the device, i.e. where the output is maximized in relation to the power input. Some devices and pumps are more sensitive to variations in these factors than others; i.e. some only function well close to a certain design condition of speed, flow and head, while others can tolerate a wide range of operating conditions with little loss of efficiency.

- Selection of Pump and Motor depends on Flow and pressure required for system.

- Pressure is calculated after adding all the losses of the system and pressure required at emitters.

- An approximate HP for motor is calculated as follows:

$$
\mathrm{HP}=\frac{\mathrm{Q} \times \mathrm{H}}{75 \times \mathrm{E} 1 \times \mathrm{E} 2}
$$

where:

$Q$ is discharge, LPS

$\mathrm{H}$ is the total head, $\mathrm{m}$;

$\mathrm{E} 1$ is the pump efficiency (fraction in the order of 0.5-0.8); and

E2 is the driving efficiency (fraction of 0.7-0.9 for electric motors and 0.5-0.75 for diesel engines).

The overall pumping efficiency under field conditions ranges accordingly from 0.35 in engine driven units to 0.50 in motor driven pumps. Higher efficiencies are not realistic.

(Always rely on manufacturer chart to know the actual horse power)

\begin{tabular}{|l|l|r|}
\hline PUMP REQUIREMENT & Unit & \\
\hline Capacity & $($ LPS $)$ & 6.46 \\
\hline Head & $(\mathrm{m})$ & 37.1 \\
\hline Motor effciency & $(\%)$ & 0.9 \\
\hline Pump Efficiency & $(\%)$ & 0.65 \\
\hline Pump H.P required & H.P & 5 \\
\hline
\end{tabular}

Project - Implementation Supervision Consultants (PSC) 


\subsubsection{Selection of Pump and Motor}

Curves for pump selection KSB - ETA 65-200
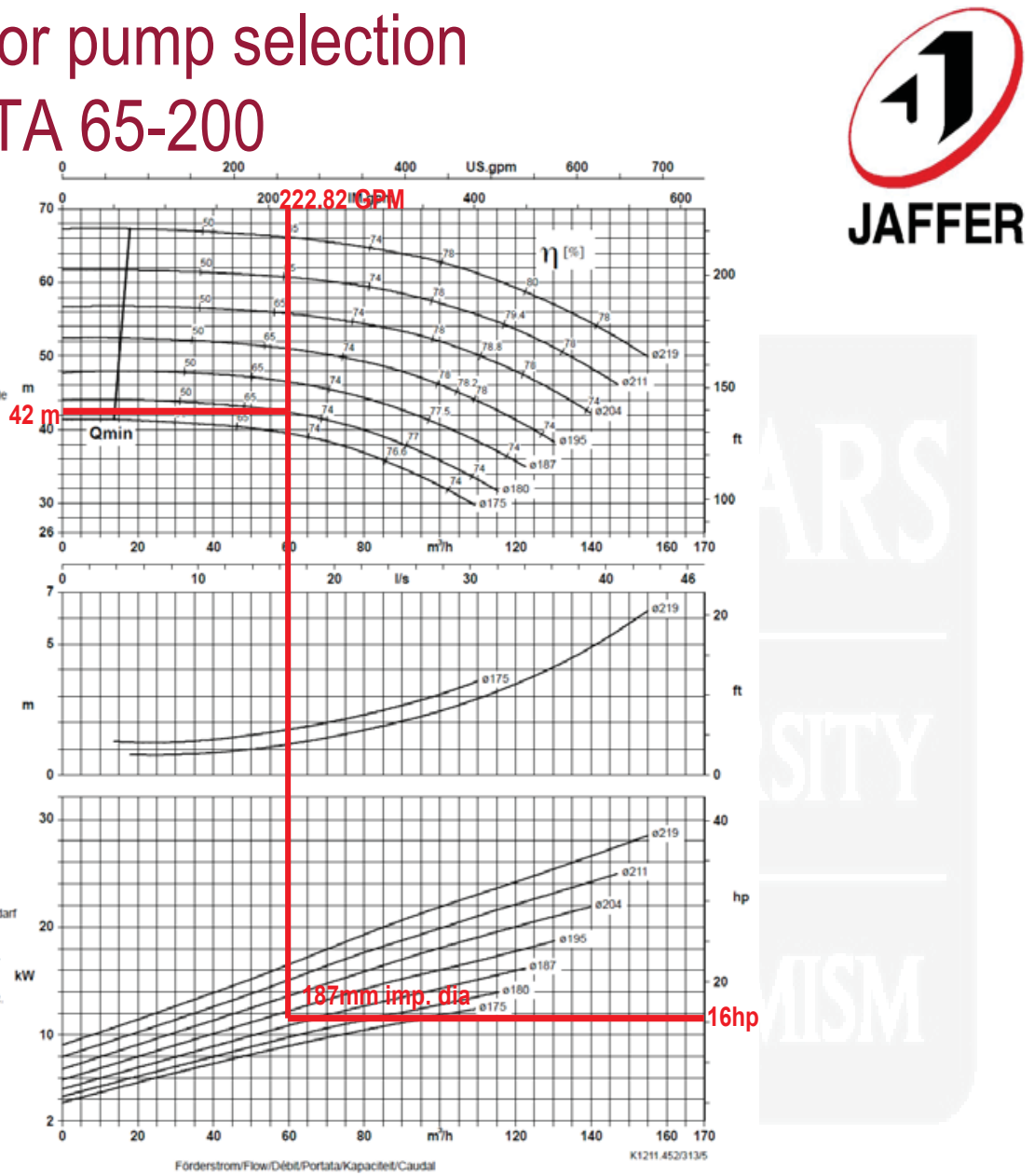

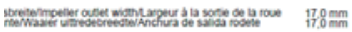




\subsubsection{Preparation of Drawing}

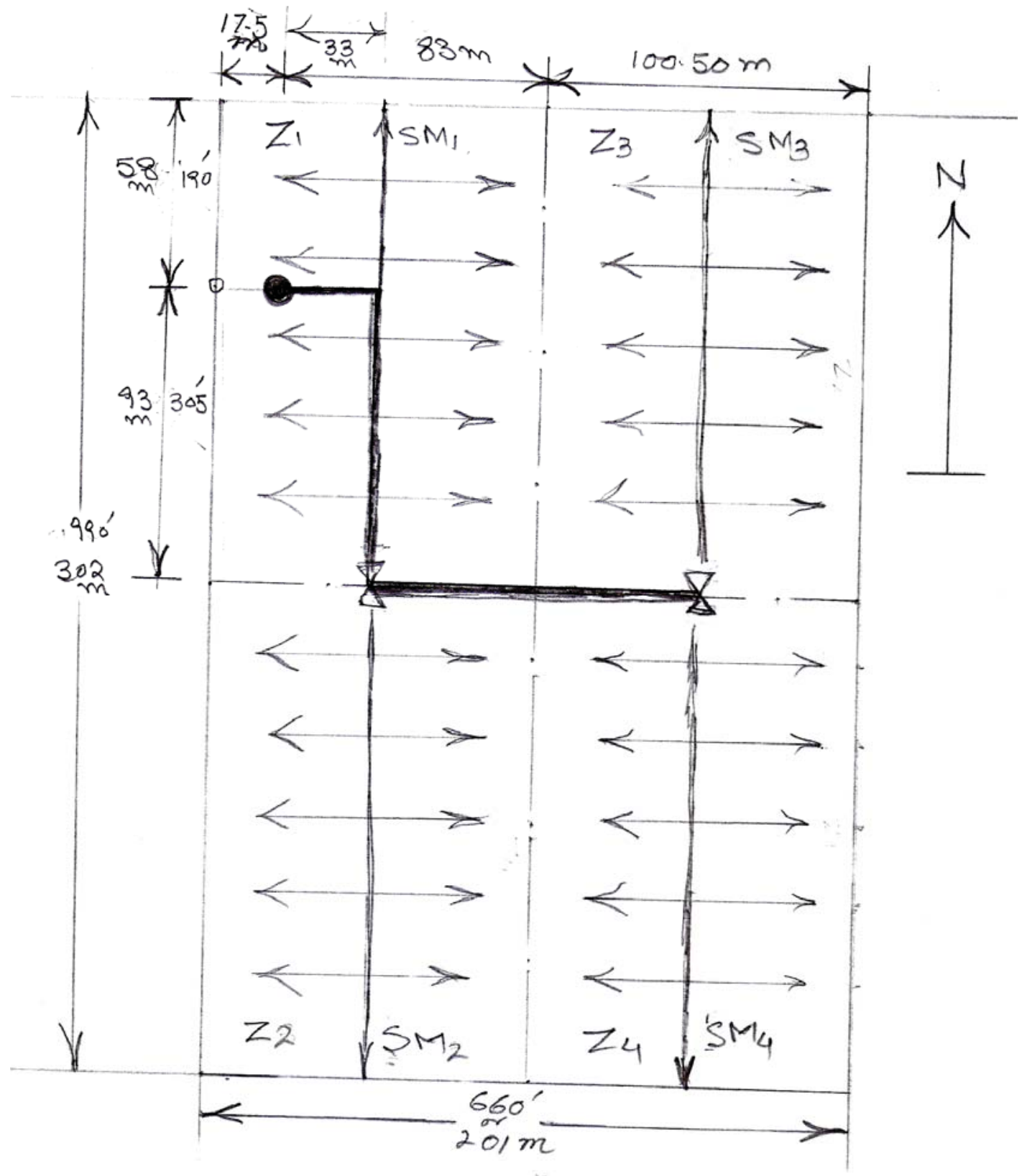

\subsubsection{Preparation of Bill of Quantities BOQ}

Bill of Quantities is divided into following subsets:

- Pump Set, Head Unit, Valves, PVC Pipes and Fittings, Emitting System

- Safety and Monitoring Equipments 


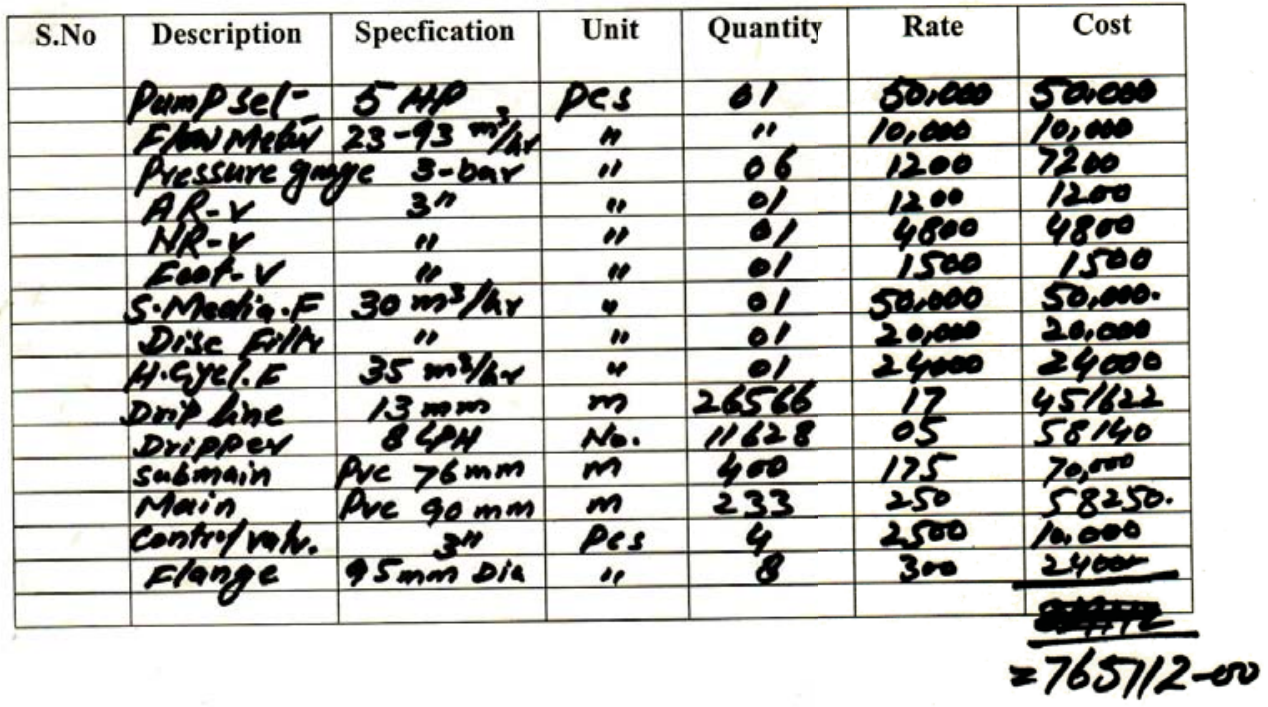

Trench, back filling $6.33 \mathrm{~m} \times 60=37980-w$ Head anit Plate Farm

- 14000 services alinges 8\%.

$=65367-00$

- 882459

parmer shere. $40 \%=352983-w$ pot Gout.share. $60 \%=529475=w$ 


\begin{tabular}{|c|c|c|c|c|c|c|c|}
\hline \multirow{2}{*}{\multicolumn{2}{|c|}{\begin{tabular}{|l|} 
Name of beneficiary: \\
Address:
\end{tabular}}} & \multicolumn{2}{|c|}{ GHULAM ABBAS QURESHI } & \multicolumn{2}{|l|}{ Designer Name: } & \multicolumn{2}{|l|}{ Arif ul Rehman } \\
\hline & & \multicolumn{2}{|c|}{ ABBAS PLAZA MUZAFERGARH } & \multicolumn{2}{|l|}{ Agronomist Name: } & \multicolumn{2}{|l|}{ M. Sagib } \\
\hline Conta & mber: & & & Area (ac): & & \multicolumn{2}{|l|}{20} \\
\hline \multicolumn{6}{|c|}{ Proposed at Design / BOQ-Memoona Sultana-AH931 } & Date: & 111212010 \\
\hline & MAKE & MODEL & SPECIFICATION & UNIT & QTY & UNIT PRICE & TOTAL PRICE \\
\hline \multicolumn{8}{|c|}{ Pump Set and Prime Mover } \\
\hline 1 & KSB & KSB 65/20 & KSB PUMP $65 / 20$ 3"X 2.5" 2900R PM(MMPELLR DIA 200MM) & NOS & 1 & \multirow{4}{*}{\multicolumn{2}{|c|}{ TO BE PROVIDED BYFARMER }} \\
\hline 2 & GOLDEN & DE 32HP & GOLDEN DIESEL ENGINE 32HP 2900RPM & NOS & 1 & & \\
\hline 3 & GOLDEN & BFDE & BASE FRAME AND COURLNGG FOR DESEL ENGINE & NOS & 1 & & \\
\hline 4 & & & SLCTION ACCESSORIES (TO BE RROVIDED BY FARMER) & NOS & 1 & & \\
\hline \multicolumn{8}{|c|}{ Filtration System+Fertigation } \\
\hline 5 & JAIN & DCYMEO & JAIN DISC CLEAN FLTER 60M3/HR YF 4" DELLXE & No. & 1 & $37,075.18$ & 37,075 \\
\hline 6 & JAIN & JHFMO8O & JANN HYDROCYCLONE SEPARATOR 80 M³HR 4" & No. & 1 & $67,725.04$ & 67,725 \\
\hline 7 & JAIN & FM060SMM & JAIN FLLRO MASTER $3^{\prime \prime} 36^{\prime \prime} 60 \mathrm{M}^{3}$ HR.M SINGLE WTH MMF & SET & 1 & $125,395.79$ & 125,396 \\
\hline 8 & JAIN & VA34 & VENTURY ASSEMBLY COMPLETE 3/4" & SET & 1 & $2,326.94$ & 2,327 \\
\hline 9 & JAIN & Fte090 & FERTILIZER TANK · 90 LITER ECONOMY & No. & 1 & $17,440.42$ & 17,440 \\
\hline 10 & Local & MFTO90 & MESH FOR FERTLIZIER TANK & No. & 1 & 3,333.33 & 3,333 \\
\hline 11 & LOCAL & GMV40 & GM VALVE 1-12" & No. & 1 & $2,107.14$ & 2,107 \\
\hline 12 & LOCAL & HUз & HEAD UNIT FTTINGS 3 & LUMPSUM & 1 & $27,928.57$ & 27,929 \\
\hline \multicolumn{8}{|c|}{ VALVES } \\
\hline 13 & Audco & BVN100 & BUTTERFLY VALVE 100 MM (4") & No. & 7 & $7,775.59$ & 54,429 \\
\hline 14 & JAIN & ARVC100 & DOLBLE ACTION AIR NACUUMM RELEASE VALVE ?" & No. & 5 & 1,417.03 & 7.085 \\
\hline 15 & JAIN & SFV63 & FLUSH VALVE 63 MM & No. & 12 & 202.03 & 2,424 \\
\hline 16 & JAIN & SFV50 & FLUSH VALVE 50 MM & No. & 1 & 172.49 & 172 \\
\hline 17 & JAIN & SFV40 & FLUSH VALVE $40 \mathrm{MM}$ & No. & 5 & 141.07 & 705 \\
\hline \multicolumn{8}{|c|}{ PVC Pipes } \\
\hline 18 & JAIN & RPA140063SGS00600 & DVVC RIRE 140MM X 6.3KG/CM2 ISO-4422 & MTR & 516 & 425.71 & 219,667 \\
\hline 19 & JAIN & RA110063SGS00600 & DPVC PIPE $110 \mathrm{MM} \times 6.3 \mathrm{KG} / \mathrm{CM} 2 \mathrm{ISO}-4422$ & MTR & 66 & 264.32 & 17,445 \\
\hline 20 & JAIN & RPA090050SGS00000 & DPVC RIPE 90MM X 5KG/CM2 ISO-4422 & MTR & 72 & 183.60 & 13,219 \\
\hline 21 & JAIN & PAAD75050SGS00000 & DPVC PIPE 75MM X 5KG/CM2 ISO-4422 & MTR & 684 & 129.77 & 88,764 \\
\hline 22 & JAIN & PPAD63050SGSO00600 & DPVC PIPE 63MM X 5KG/CM2 ISO-4422 & MTR & 696 & 94.32 & 65,647 \\
\hline 23 & JAIN & RAD50063SGS00600 & DPVC PIPE 50MM X 6.3KG/CM2 ISO-4422 & MTR & 84 & 81.92 & 6,882 \\
\hline 24 & JAIN & PPADA0063SGSO0600 & DPVC PIRE 40MM X 6.3KG/CM2 ISO-4422 & MTR & 192 & 53.76 & 10,322 \\
\hline 25 & JAIN & $F \& A$ & FITTNGS AND ACCESSORIES & LUMPSLM & 1 & & 42,195 \\
\hline \multicolumn{8}{|c|}{ EMITTING SYSTEM (INLINE LATERALS) } \\
\hline 26 & JAIN & PT122 & 12MM ODA0.2MM ID, MNIMUM 0.9MM W.T. & MTR & 2000 & 11.08 & 22,170 \\
\hline 27 & JAIN & JTA1204502 & 12MM, MINIMUM 0.6MM W.T,4LPH,50CMS SPACNNG & MTR & 53500 & 10.86 & 580,794 \\
\hline 28 & JAIN & GT001213 & POLY GROMMET TAKE OFF $12 \times 13$ MM & SET & 1700 & 8.95 & 15,223 \\
\hline 29 & JAIN & TL12 & J-TURBO AQURA /J TURBO LINEJONNER L MM & No. & 1800 & 6.13 & 11,028 \\
\hline 30 & JAIN & ES0812 & LATERAL END STOP “8” SHAPE I MM & No. & 1700 & 5.03 & 8,546 \\
\hline 31 & JAIN & PGGFLC & PRESSURE GAULEE GLYCERNN FLLED LATERAL CHECK & SET & 2 & 967.73 & 1,935 \\
\hline \multicolumn{8}{|c|}{ ADDITIONAL SAFETY AND MONITORING EQUIPMENT } \\
\hline 32 & Capstan & CWMAET & CADSTAN WATER METER 4"ENC. TYTE 100 MM & No. & 1 & $25,663.56$ & 25,664 \\
\hline 33 & LOCAL & NRV25 & C. I. NON RETURN VALVE $2.5^{\prime \prime}$ & No. & 1 & $10,086.54$ & 10,087 \\
\hline \multicolumn{8}{|c|}{ OTHER CHARGES } \\
\hline 34 & & & TRENCHING AND BACKFLLING & RFT & 6500 & 14.29 & 92,885 \\
\hline \multicolumn{3}{|c|}{ TOTAL PRICE IN PAK RUPEES } & & & & & $1,580,622$ \\
\hline & & & SER VICE CHARGES & & & $9.00 \%$ & 142,256 \\
\hline Spare & & & & & & & \\
\hline 1 & JAIN & JTA1204502 & 12MM, MINIMLMM 0.6MM W.T,4LPH,50CMS SPACING & MTR & 1000 & 11 & 10,856 \\
\hline 2 & JAIN & TL12 & J-TURBO AQURA/J TURBO LINEJONNER L MM & NO. & 400 & 6 & 2,451 \\
\hline 3 & JAIN & PGGFLC & TRESSURE GAULEE GLYCERNN FLLED LATERAL CHECK & SET & 1 & 967.73 & 968 \\
\hline 4 & JAIN & ES0812 & LATERAL END STOP "8” SHADE 12 MM & NO. & 300 & 5 & 1,508 \\
\hline TOT & ROJEC & ICE & & & & & $1,738,660$ \\
\hline
\end{tabular}

Note: The above quotation does not include cost of construction of PondlBore well and pumpset with prime mover along with the suction accessories. This will be provided by beneficiary as per specification provided by SSC. 


\section{Example Orchard - 1}

Design a drip irrigation system for citrus using following data:

$\begin{array}{llll}\text { Size of the field } & = & 1 \text { ha } \\ \text { Shape } & = & \text { assume square plot of } 100 \mathrm{~m} \times 100 \mathrm{~m} \\ \text { Type of drippers } & = & \text { on-line } \\ \text { Plant spacing } & 6.09 \mathrm{~m} \\ \text { Row spacing (Lateral spacing) } & =\quad 6.09 \mathrm{~m} \\ \text { Discharge of dripper } & 8 \mathrm{LPH} \text { at } 1 \mathrm{Kg} / \mathrm{cm}^{2} \\ \text { Maximum ETo } & 8 \mathrm{~mm} / \text { day } \\ \text { Kc for citrus } & =\quad 0.70 \\ \text { Area to be wetted as a } & & \\ \text { Percentage of total area } & = & 60 \% \\ \text { Soil type } & = & \text { clay loam } \\ \text { Availability of electricity per day } & = & 12 \text { hours } \\ \text { Topography of field } & = & \text { level } \\ \text { Application efficiency } & 90 \% & \\ \text { Hazen-William constant } & = & 150 \text { for PVC pipe and } 140 \text { for LDPE pipes }\end{array}$

Assume water source is at the corner of the field.

Solution:

\section{A) Computation of water requirement of the area}

Consumptive use can be calculated using equation - 4.6

$$
\begin{aligned}
\mathrm{CU} & =\quad \text { Eto } \times \mathrm{Kc} \times \mathrm{Kf} \div \text { efficiency } \\
& =8 \times 0.70 \times 0.60 /(90 / 100) \\
& =3.73 \mathrm{~mm} / \text { day }
\end{aligned}
$$

\section{B) Calculation of number of plants}

Total no. of plants can be calculated by using equation

$$
\begin{aligned}
N_{p} \quad & A / A_{p} \\
& =10000 /(6.09 \times 6.09) \\
& =269 \text { plants }
\end{aligned}
$$

\section{C) Selection of emitters}

Numbers of emitters are selected based on the equation.

$$
\mathrm{e}=S_{\mathrm{P}} \times S_{R} \times P_{w} / A_{w}
$$

The value of Aw is selected from Table-3.10 for loam (medium) soil and is used in the above equation to find the no. of emitters per plant. 


$\begin{aligned} \mathrm{e} & =6.09 \times 6.09 \times 0.60 / 3.87 \\ & =5.8 \\ & =6 \text { (Approx.) }\end{aligned}$

Total no. of drippers required for the area can be calculated using equation

$\begin{aligned} \mathrm{N} & =\mathrm{Np} \times \mathrm{e} \\ & =269 \times 6 \\ & =1614\end{aligned}$

\section{D) Computation of Flow Rate}

Total flow rate can be calculated by using equation

$$
\begin{aligned}
\mathrm{Q} & = & \mathrm{Np} \times \mathrm{e} \times \mathrm{q} \\
& = & 269 \times 6 \times 8 \\
& = & 12912 \mathrm{LPH}
\end{aligned}
$$

\section{E) Lateral Requirement}

Two no. of drip line for one row of plants is suggested and the total drip line length for the area can be calculated by using equation

$$
\begin{array}{rlrl}
\mathrm{L} \quad \text { K. A. NI./ Ls } & \\
= & & 4047 \times 2.471 \times 2 / 6.09 \\
& = & 3284 \mathrm{~m}
\end{array}
$$

\section{F) Application Rate}

Application rate can be calculated using equation -4.29

$$
\begin{aligned}
\mathrm{I} & =\mathrm{Q} / \mathrm{A} \\
& =12912 / 10000 \\
& =1.29 \mathrm{~mm} / \mathrm{hr}
\end{aligned}
$$

\section{G) Total Operation Time}

Operation time can be calculated using equation -4.31

$$
\begin{array}{rlrl}
\mathrm{T} & = & \mathrm{Cu} / \mathrm{I} \\
& = & 3.73 / 1.29 \\
& =2.89 \mathrm{hrs}
\end{array}
$$

Here it comes the decisive moment to prepare layout for pipe network. The entire system can be irrigated in one operation requiring larger sized head unit components and pipe networks resulting higher initial investments but less operation hours. The same system can further be economized by diving the area into zones (may be four) that will result in approximately 12 hours of operations but smaller sized head unit components and pipe diameters. To make design calculations easier, the entire system is to irrigate in a single operation. 


\section{H) Selection and Design of Lateral}

For economy, divide the flow into two sections and give the submain at the center of plot.

i) Length of lateral on one side of sub-main= $50 \mathrm{~m}$

No. of plants on one lateral $\quad=\quad$ Lateral length / plant spacing

$=\quad 50 / 6.09$

$=8$

ii) Two no. of laterals for one crop row are suggested @ 3 no. of drippers on each lateral per plant, so the total no. of drippers on each lateral can be calculated as:

$=\quad$ No. of plants on each lateral $\mathrm{X}$ no. of dripper per plant per lateral

$=8 \times 3$

$=24$ no.

iii) Flow rate of the lateral can be calculated by using equation as:

$=\quad$ Total no. of dripper on each lateral X Flow rate of each emitter

$=24 \times 8$

$=\quad 192 \mathrm{LPH}$

Select $12 \mathrm{~mm}$ diameter lateral (thickness of the lateral is $1.1 \mathrm{~mm}$ ), inside diameter of lateral = $12-(1.1+1.1)$

$=\quad 9.8 \mathrm{~mm}$

Using equation - 5.2 (Watter and Keller)

$\begin{array}{rlll}\mathrm{J}= & 100 \mathrm{hf} / \mathrm{L} & & \mathrm{K} \mathrm{Q}^{1.75} / \mathrm{D}^{4.75} \\ = & 100 \mathrm{hf} /(50 \mathrm{~m})= & 7.89 \times 10^{7} \times(192 / 3600)^{1.75} / 9.8^{1.75} \\ & = & 9.14 \mathrm{~m} \\ & & = & 9.14 \times 50 / 100=4.57 \mathrm{~m}\end{array}$

Multiplying by outlet factor for multiple outlets i.e., 0.36 taken from Table 6.2.

Total head loss in lateral $=4.57 \times 0.36=1.65 \mathrm{~m}$

Head loss due to friction for $50 \mathrm{~m}$ lateral length $=1.65 \mathrm{~m}$

Emitter operating pressure is $10 \mathrm{~m}$ and calculated head loss $1.65 \mathrm{~m}$ is less than $20 \%$, which means flow variation is less than $10 \%$. Lateral of $12 \mathrm{~mm}$ size is sufficient to carry the flow.

\section{I) Selection and Design of Sub-main}

i) Length of sub-main $=100 \mathrm{~m}$

ii) No. of lateral on one side of submain

$$
\begin{array}{ll}
= & 2 \times(\text { Submain length } / \text { Lateral spacing }) \\
= & 2 \times(100 / 6.09) \\
= & 33
\end{array}
$$


iii) No. of laterals on submain $=33 \times 2$

$=66$

iv) Flow rate in submain

$=\quad$ flow rate in one lateral $X$ No. of laterals on submain

$=192 \times 66$

$=\quad 12672 \mathrm{LPH}$

Which is approximately the same as calculated total flow of area considering total plants in the area i.e $12912 \mathrm{LPH}$

v) Outlet factor (66 outlet) for sub main $=\quad 0.36$

Select $60.5 \mathrm{~mm}$ diameter of sub main, inside diameter of sub main $=55.5 \mathrm{~mm}$

Using equation -5.2 (Water and Keller) as described in lateral size calculation

Head loss due to friction for $100 \mathrm{~m}$ sub main length $=1.53 \mathrm{~m}$

\section{J) Calculation of Flow Velocity}

Flow velocity can be calculated using equation 5.4.

$$
\begin{aligned}
\mathrm{V} & =\mathrm{KQ} / \mathrm{D}^{2} \\
& =1273(12912 / 3600) /(55.5)^{2} \\
& =1.48 \mathrm{~m} / \mathrm{s}
\end{aligned}
$$

As the calculated head loss is less than $2 \mathrm{~m}$, also the velocity is also less than the maximum permissible limit of $2.5 \mathrm{~m} / \mathrm{s}$, the sub-main of $60.5 \mathrm{~mm}$ size is sufficient to carry the flow. Therefore, the design of sub-main is acceptable.

\section{K) Selection and design of mainline}

i) Length of main line $\quad=\quad 50 \mathrm{~m}$

ii) Flow rate of main line $=\quad$ Flow rate of submain

$=\quad 12912 \mathrm{LPH}$

Select $60.5 \mathrm{~mm}$ diameter of submain, inside diameter of submain $=55.5 \mathrm{~mm}$

Using equation - 6.2 (Watter and Keller)

Head loss due to friction for $100 \mathrm{~m}$ lateral length $\quad=\quad 3.82 \mathrm{~m}$

Head loss due to friction for $50 \mathrm{~m}$ main line length $=1.91 \mathrm{~m}$

Velocity $\quad=1.48 \mathrm{~m} / \mathrm{s}$

The calculated velocity for mainline is less than the maximum permissible limit of $1.5 \mathrm{~m} / \mathrm{s}$, the mainline of $60.5 \mathrm{~mm}$ size is sufficient to carry the flow. Therefore, the design of mainline is acceptable. 
The head loss for suction and delivery pipe for pump be calculated using the same equation (Water \& Keller)

Suction and delivery head loss

Total head losses in piping network

Fitting losses

(may be taken $20 \%$ of the pipe losses)

Emitter operating pressure in form of water head
$=0.09 \mathrm{~m}$

$=\quad 1.65+1.53+0.09$

$=5.18 \mathrm{~m}$

$=\quad 1.04 \mathrm{~m}$

$=10 \mathrm{~m}$

Head losses for fittings, filters, fertigation system and other flow control and monitoring devices shall be added as given by the vendors.

\section{Assume,}

Head loss in fertigation

Head losses in filters

$=5 \mathrm{~m}$

Head loss in flow meter

$=8 \mathrm{~m}$

Misc. head losses

$=1 \mathrm{~m}$

$=2 \mathrm{~m}$

The total dynamic head can be calculated by adding all the head losses occurring in the system and can be presented as follow:

Total Dynamic Head $=30.22 \mathrm{~m}$

Pump flow rate $\quad=12912(\mathrm{LPH}) / 3600$ (Sec.)

$$
=\quad 3.59 \text { LPS }
$$

\section{L) Horse Power Requirement}

Horse Power Requirement can be calculated using equation

$$
\text { H.P = Q.H } /[75 \times E m \times E p]
$$

The efficiencies for pump and electric motor are assumed as $60 \%$ and $80 \%$ respectively.

$$
\begin{aligned}
& =3.59 \times 30.22 /[75 \times 0.6 \times 0.8] \\
\text { Required Horse Power } & =3.0 \text { (appx.) }
\end{aligned}
$$




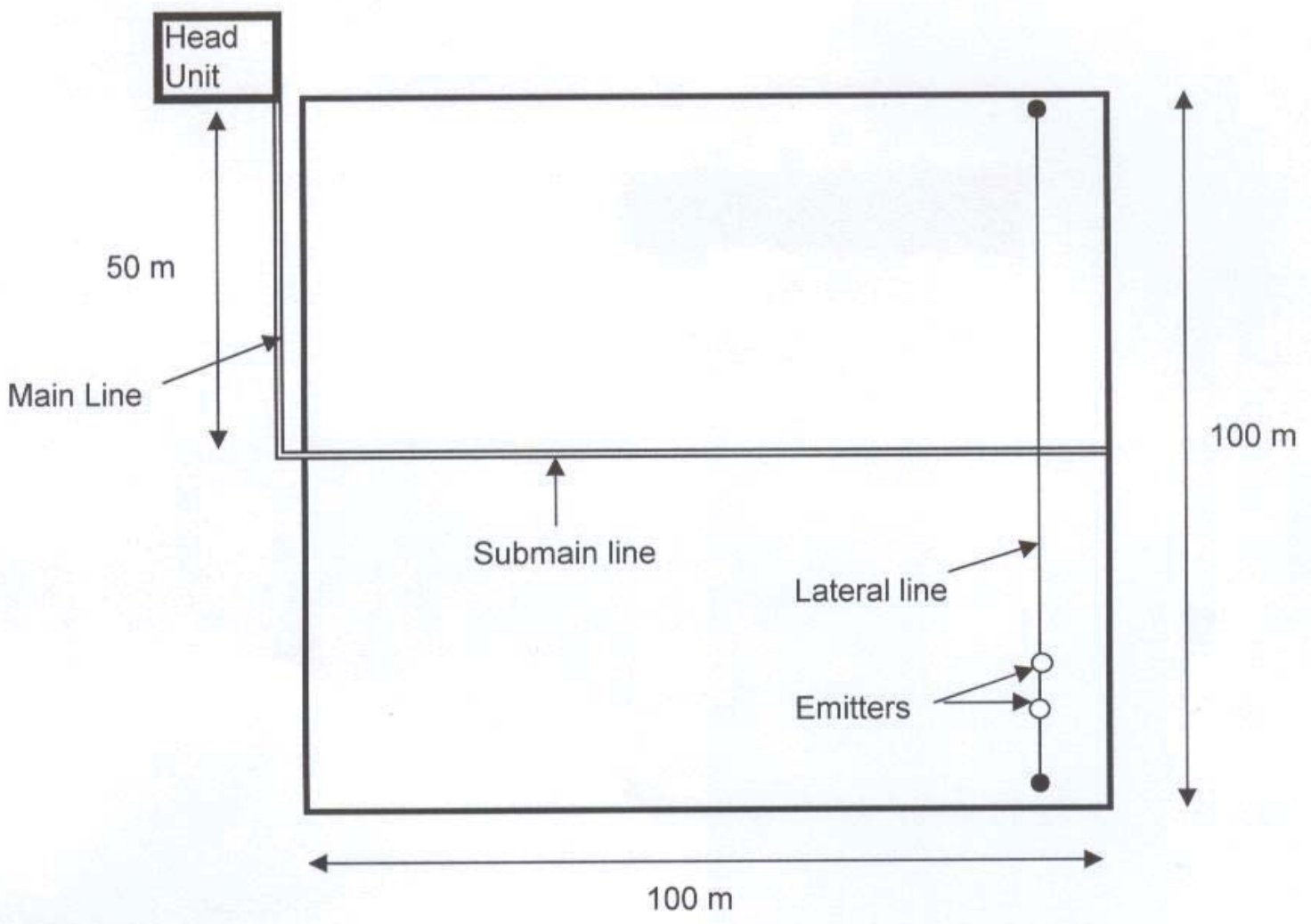

Fig. 6.2 Design layout for drip irrigation system

\section{Example Orchard - 2}

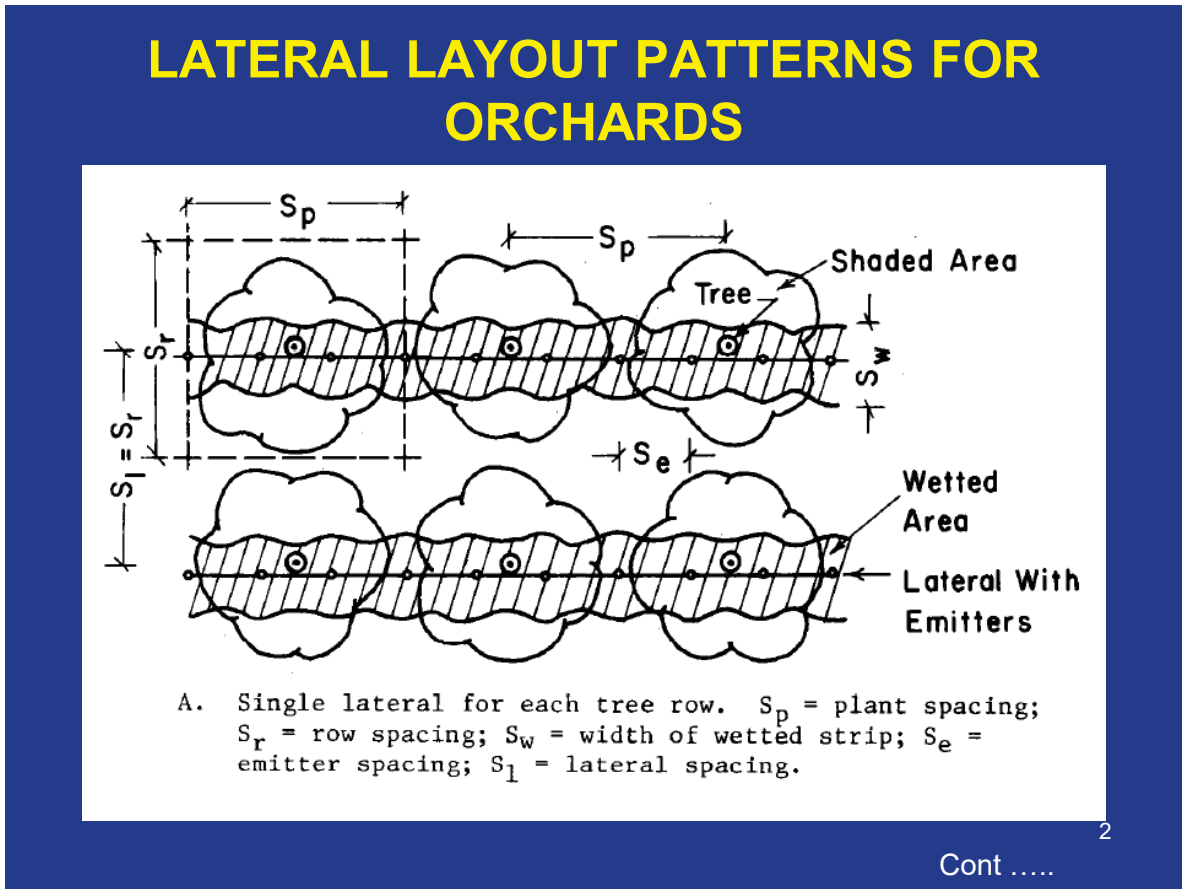



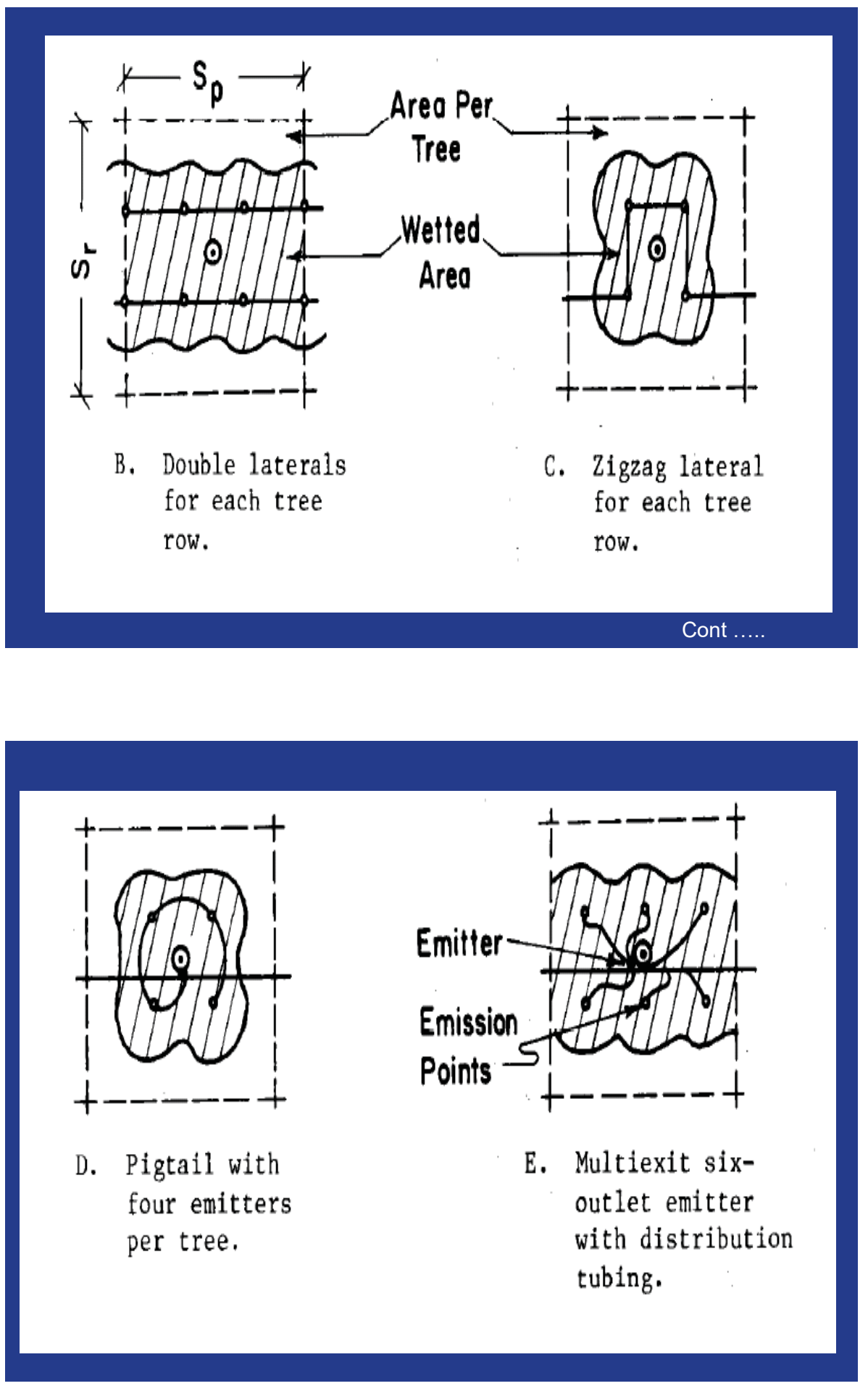


\section{AREA WETTED BY ONE EMITTER}

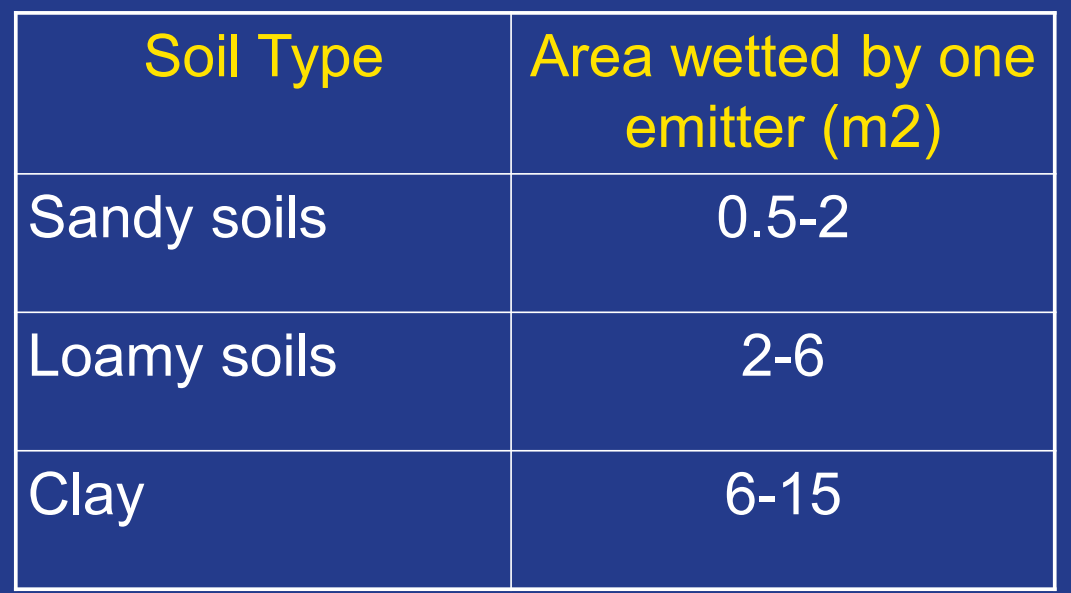

Rain Bird, 1980

\section{Percent Wetted Area}

- The percentage area wetted Pw is the average horizontal area wetted within the top $30 \mathrm{~cm}$ of the crop root zone depth in relation to the total cropped area.

- For largely spaced crops such as orchards is to wet at least one third and as much as two third $(33 \%-66 \%)$ of potential horizontal area of the plant root system.

- In closely spaced crops with rows and emitter laterals spaced less than $1.8 \mathrm{~m}$ apart often reaches $100 \%$.

\section{Example}

Percentage Wetted Area Pw=

no. of emitters $x$ area wetted by single emitter

Row to Row x Plant-Plant distance

No. of emitters

$=4$

Area wetted by single emitter

$=4 \mathrm{~m} 2$

Row to Row distance

$=4.57 \mathrm{~m}$

Plant-Plant distance

$=4.57 \mathrm{~m}$

$P w=4 \times 4 / 4.57 \times 4.57$

$=77 \%$ 


\section{Design a drip irrigation system for Citrus Orchard in Okara District.}

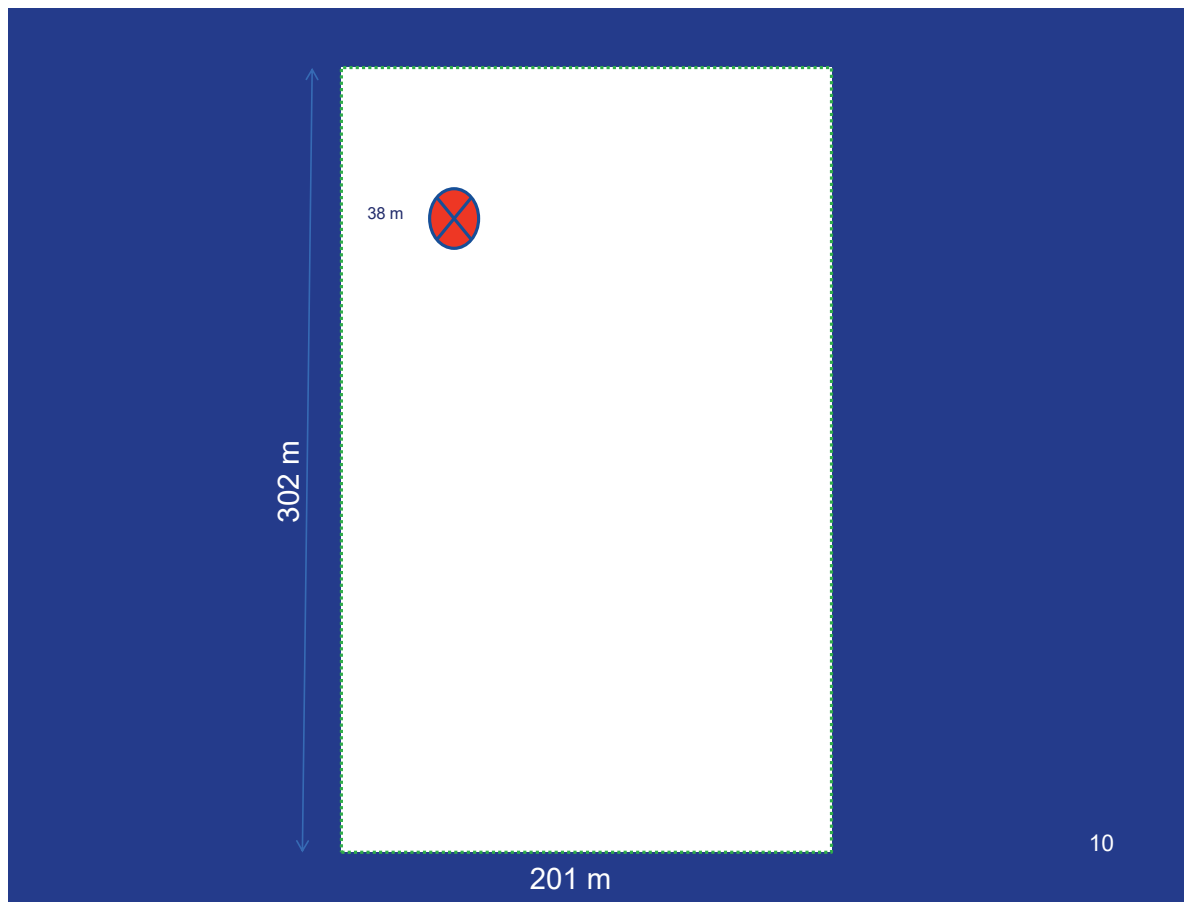

\section{Crop Information}

\begin{tabular}{|c|c|c|c|c|c|c|c|c|c|}
\hline \multicolumn{3}{|c|}{ Parameters } & Crop & $\begin{array}{r}\text { Area } \\
\text { (acres) }\end{array}$ & $\begin{array}{l}\text { Plant } \\
\text { spacing }\end{array}$ & $\begin{array}{l}\text { Row } \\
\text { spacing }\end{array}$ & $\begin{array}{l}\text { Age of } \\
\text { crop }\end{array}$ & $\begin{array}{c}\text { Sowing } \\
\text { Date }\end{array}$ & $\begin{array}{c}\text { Harvestin } \\
\text { g Date }\end{array}$ \\
\hline \multirow{2}{*}{ Block-I } & \multirow{2}{*}{ Row crops } & Proposed & Citrus & 15 & 4.57 & 4.57 & 1 year & & \\
\hline & & Rotation & & & & & & & \\
\hline \multicolumn{3}{|c|}{ Sub-Total: I } & & & & & & & \\
\hline \multirow{2}{*}{ Block-II } & \multirow{2}{*}{ Orchards } & Type-I & & & & & & & \\
\hline & & Type-II & & & & & & & \\
\hline \multicolumn{3}{|c|}{ Sub-Total: II } & & & & & & & \\
\hline Block-III & \multicolumn{2}{|c|}{ Annual Crops } & & & & & & & \\
\hline \multicolumn{3}{|c|}{ Sub-Total: III } & & & & & & & \\
\hline \multirow{2}{*}{ Block-IV } & \multirow{2}{*}{ Field Crops } & Type-I & & & & & & & \\
\hline & & Type-II & & & & & & & \\
\hline \multicolumn{3}{|c|}{ Sub-Total: IV } & & & & & & & \\
\hline \multicolumn{3}{|c|}{ Total / Design Value } & & 15 & 4.57 & 4.57 & & & \\
\hline
\end{tabular}




\section{Water Sources}

\begin{tabular}{|c|c|c|}
\hline \multicolumn{2}{|l|}{ Soil type } & Loamy Sand \\
\hline \multicolumn{2}{|l|}{ Water Sources } & \\
\hline \multicolumn{2}{|l|}{ 1) Canal } & \\
\hline \multicolumn{2}{|c|}{ Sanctioned Discharge (LPS) } & 56 \\
\hline \multicolumn{2}{|c|}{ Perennial / Non Perennial } & Perennial \\
\hline \multicolumn{2}{|l|}{ Warabandi (Days) } & 7 \\
\hline \multirow[t]{2}{*}{ Water Availability } & Hrs/Warabandi & 8 \\
\hline & Volume (m3) & 1612 \\
\hline
\end{tabular}

\section{EVAPOTRANSPIRATION AND CROP COEFFICIENTS (ETO \& Kc)}

\begin{tabular}{|l|l|l|l|l|l|l|l|l|l|l|l|l|}
\hline Month & J & F & M & A & M & J & J & A & S & O & N & D \\
\hline Eto (mm/d) & 1.4 & 2.2 & 3.6 & 5.0 & 6.3 & 6.5 & 5.2 & 4.7 & 4.5 & 3.2 & 1.8 & 1.3 \\
\hline Kc (row crop) & 0.65 & 0.65 & 0.65 & 0.65 & 0.65 & 0.65 & 0.65 & 0.65 & 0.65 & 0.65 & 0.65 & 0.65 \\
\hline CWR (row crop) & 0.9 & 1.4 & 2.3 & 3.3 & 4.1 & 4.2 & 3.4 & 3.1 & 2.9 & 2.1 & 1.2 & 0.8 \\
\hline Kc (orchards) & & & & & & & & & & & & \\
\hline CWR (orchards) & & & & & & & & & & & & \\
\hline Kc (annual crop) & & & & & & & & & & & & \\
\hline CWR (annual crop) & & & & & & & & & & & & \\
\hline Kc (field crops) & & & & & & & & & & & & \\
\hline CWR (field crops) & & & & & & & & & & & & \\
\hline
\end{tabular}




\begin{tabular}{|r|l|l|l|}
\hline 1. & Total area under HEIS & Acres & 15 \\
\hline 2. & Design reference evapotranspiration, ETo & $\mathrm{mm} /$ day & 6.5 \\
\hline 3. & Design Crop factor at maturity, Kc & - & 0.65 \\
\hline 4. & Plant spacing & $\mathrm{m}$ & 4.57 \\
\hline 5. & Row spacing & $\mathrm{m}$ & 4.57 \\
\hline & Canopy Area & $\mathrm{m} 2$ & 14.62 \\
\hline 6. & Canopy Factor & $\%$ & 70 \\
\hline 7. & Irrigation system efficiency & $\%$ & 90 \\
\hline & Optimum wetted width of each emitter & $\mathrm{m}$ & \\
\hline 8. & Emitter flow rate & LPH & 8 \\
\hline & No. of emitters per plant & Nos. & 4 \\
\hline 10. & No. of drip lines per plant rows & Nos. & 2 \\
\hline 11. & Irrigation cycle (assume one day) & Days & 1 \\
\hline & & & \\
\hline
\end{tabular}

\begin{tabular}{|c|c|c|c|}
\hline S.N & Parameters & Unit & Calculations \\
\hline 13 & $\begin{array}{l}\text { Peak daily consumptive } \\
\text { use per day }\end{array}$ & $\mathrm{Mm}$ & $\begin{array}{l}=\mathrm{ETO} * \mathrm{Kc} * \text { canopy factor/ efficiency } \\
=6.5 * 0.65 * 0.7 / 0.9=3.29 \mathrm{~mm}\end{array}$ \\
\hline 14 & Total no. of plants & Nos & $\begin{array}{l}=\text { Area } \times 4047 /(R-R * P-P) \\
=15^{*} 4047 /\left(4.57^{*} 4.57\right)=2,908\end{array}$ \\
\hline 15 & Total drip line length & M & $\begin{array}{l}=\text { Area* } 4047 \times \text { no of lines per plant row } / L-L \\
=15^{*} 4047 \times 2 /(4.57)=26,566\end{array}$ \\
\hline 16 & Total no. of emitters & Nos & $\begin{array}{l}=\text { Total no. of plants } \times \text { no. of emitters per plant } \\
=2908 \times 4=11,632\end{array}$ \\
\hline 17 & Average emitter spacing & M & 2.3 \\
\hline 18 & Total flow rate & Lph & $\begin{array}{l}=\text { total no. of emitters } x \text { emitter flow rate } \\
=11632 * 8=93,056\end{array}$ \\
\hline 19 & Application rate & $\mathrm{Mm} / \mathrm{hr}$ & $\begin{array}{l}\text { Total flow rate } / \text { area } \\
=(93,056 / 1000) /\left(15^{*} 4047^{*} 1000\right) \\
=1.53\end{array}$ \\
\hline 20 & Operation time* & hrs & $\begin{array}{l}=\text { Peak daily consumptive use/ Application rate } \\
=3.29 / 1.53 \\
=2.15 \mathrm{hrs}\end{array}$ \\
\hline
\end{tabular}


Drip design sheet-orchard

\begin{tabular}{|c|c|c|c|c|c|}
\hline Sr. No & Parameters & $\begin{array}{c}\text { Formula } \\
\text { Description }\end{array}$ & Units & Zone I & Total \\
\hline 1 & Total area under HEIS & $A$ & Acres & 3.75 & 15.00 \\
\hline 2 & Reference Evapotranspiration (ET) & & $\mathrm{Mm} / \mathrm{d}$ & 6.50 & \\
\hline 3 & Crop Factor (Kc) & & & 0.65 & \\
\hline 4 & Plant spacing & & $\mathrm{M}$ & 4.57 & \\
\hline 5 & Row spacing/ Lateral spacing & & $M$ & 4.57 & \\
\hline 6 & Canopy Diameter & $\mathrm{Cd}$ & $\mathrm{M}$ & 4.31 & \\
\hline 7 & Canopy Area & $\begin{array}{l}\text { Ca=3.1416 x } \\
\text { Canopy diameter } \\
\wedge 2 / 4\end{array}$ & $\mathrm{~m} 2$ & 14.6 & \\
\hline 8 & Canopy factor at maturity & $\begin{array}{l}\mathrm{Cf}=\text { Canopy } \\
\text { Area/Plant Spacing } \\
\text { x Lateral Spacing }\end{array}$ & Fraction & 0.70 & \\
\hline 9 & Irrigation system efficiency & & $\%$ & 0.9 & \\
\hline 10 & Emitter flow rate & & $\mathrm{LPH}$ & 8 & \\
\hline 11 & \multicolumn{2}{|c|}{$\begin{array}{l}\text { Optimal wetted width of each emitter }(30 \mathrm{~cm}) \text { below soil } \\
\text { surface at peak water demand) }\end{array}$} & & & \\
\hline 12 & No. of emitter/dripper per plant & & Nos. & 4 & \\
\hline 13 & Emitter spacing along plant canopy & & & & \\
\hline 14 & No. of drip lines per plant row & & Nos. & 2 & \\
\hline 15 & $\begin{array}{l}\text { Optimal distance between two } \\
\text { Laterals }\end{array}$ & & $\mathrm{M}$ & & \\
\hline 16 & Irrigation cycle (assume one day) & & Days & 1.0 & \\
\hline 17 & Peak daily consumptive use per day & $\begin{array}{l}\text { Reference ET x } \\
\text { crop factor x } \\
\text { Canopy } \\
\text { factor/Efficiency }\end{array}$ & $\mathrm{Mm} / \mathrm{d}$ & 3.28 & \\
\hline 18 & Total no. of plants & $\begin{array}{l}\text { Area } \times 4047 / \text { Plant } \\
\text { Spacing } \times \text { Lateral } \\
\text { Spacing }\end{array}$ & Nos. & 727 & 2907 \\
\hline 19 & Total drip line length & $\begin{array}{l}\text { Area } \times 4047 \times \text { No. } \\
\text { of drip lines per } \\
\text { plant row/Lateral } \\
\text { Spacing }\end{array}$ & M & 6642 & 26,567 \\
\hline 20 & Total no. of emitters/drippers & $\begin{array}{l}\text { Total no. of plants } x \\
\text { drippers per plant }\end{array}$ & Nos. & 2907 & 11,627 \\
\hline 21 & Average emitter spacing & $\begin{array}{l}\text { Total drip line } \\
\text { length/Total no. of } \\
\text { emitters }\end{array}$ & M & 2.29 & \\
\hline 22 & Total flow rate & $\begin{array}{l}\text { Total no. of emitters } \\
\text { x emitter flow rate }\end{array}$ & LPH & 23,253 & 93,013 \\
\hline 23 & & & LPS & 6.46 & 25.84 \\
\hline 24 & & & $\mathrm{~m} 3 / \mathrm{hr}$ & 23.25 & 93.01 \\
\hline 25 & Application rate & $\begin{array}{l}\text { (Total flow } \\
\text { rate/1000)/(Area x } \\
4047) \times 1000\end{array}$ & $\mathrm{Mm} / \mathrm{hr}$ & 1.53 & 0.00 \\
\hline 26 & Operation time* & $\begin{array}{l}\text { Peak daily } \\
\text { consumptive use } \\
\text { per day/Application } \\
\text { rate }\end{array}$ & Hrs & 2.14 & 8.56 \\
\hline 27 & Vol. of water req./operation/day & $\begin{array}{l}\text { Flow } x \text { operational } \\
\text { time }\end{array}$ & $\mathrm{m} 3$ & 50 & 199 \\
\hline
\end{tabular}




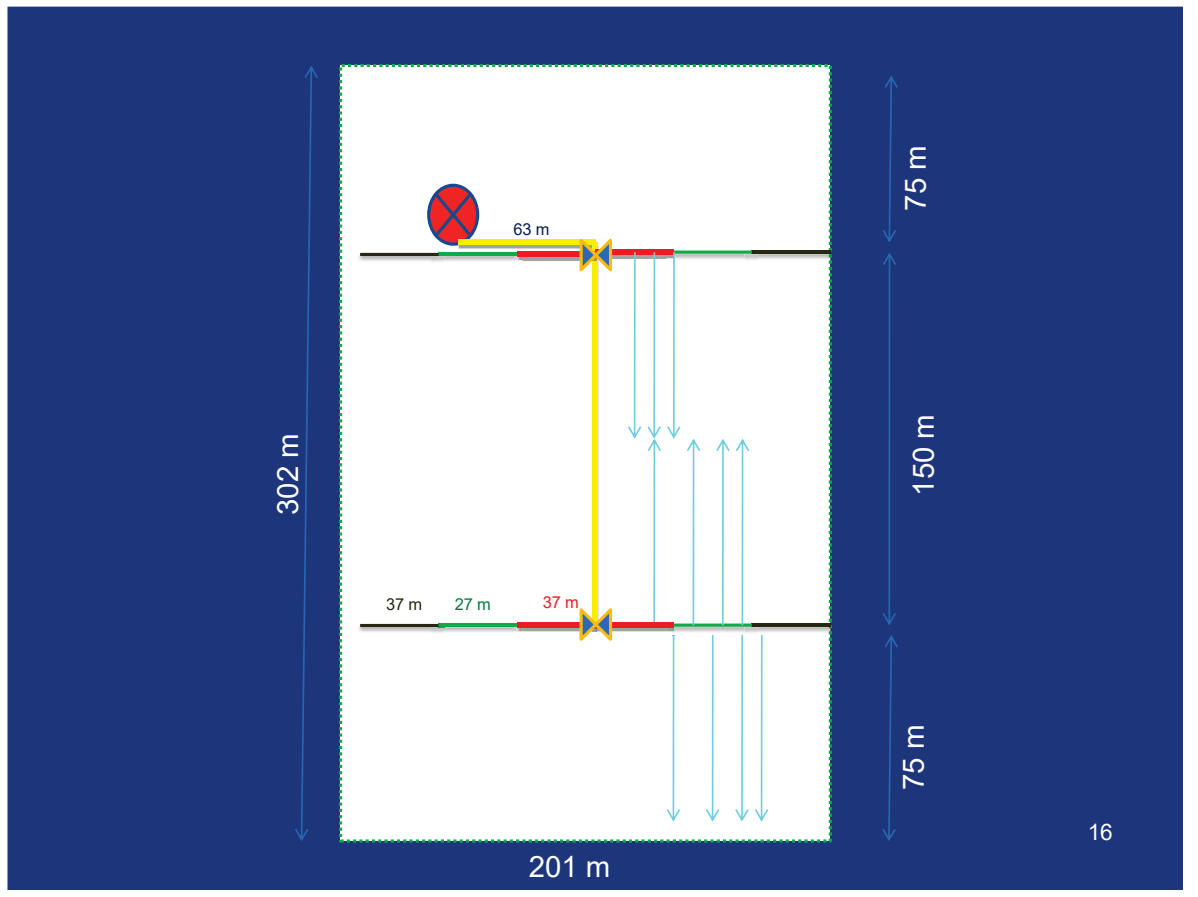

Darcy- Weisbach and Blasius Equation can be combined to give accurate prediction of friction head loss for smooth plastic pipes of less than $125 \mathrm{~mm}$ (5 in.) diameter.

$$
\begin{array}{ll}
\mathrm{J}=100 \mathrm{hf} / \mathrm{L}=\mathrm{k}^{*}\left[\left(\mathrm{Q}^{\wedge} 1.75\right) /\left(\mathrm{D}^{\wedge} 4.75\right)\right]^{*} \mathrm{~F} \\
\mathrm{~J} & =\text { Head loss gradient, } \mathrm{m} / 100 \mathrm{~m} \\
\mathrm{Hf} & =\text { pipe friction head loss, } \mathrm{m} \\
\mathrm{K} & =\text { Constant, } 7.89{ }^{*} 10^{\wedge} 7 \text { for metric units } \\
\mathrm{Q} & =\text { Flow Rate, LPS } \\
\mathrm{L} & =\text { Pipe length, } \mathrm{m} \\
\mathrm{D} & =\text { Inside Diameter of Pipe, } \mathrm{mm}
\end{array}
$$

\section{Lateral Design:}

Lateral length $=73 \mathrm{~m}$

No. of emitters $=73 / 2.3=32$

Lateral flow rate $=32 * 8=256 \mathrm{lph}$

Assume $16 \mathrm{~mm}$ lateral line

Inside diameter $=14.2 \mathrm{~mm}$

$\left.J=7.89^{*} 10^{\wedge} 7^{*}\left[(256 / 3600)^{\wedge} 1.75\right) /\left(14.2^{\wedge} 4.75\right)\right]^{*} 0.36$

$\mathrm{J}=0.93 \mathrm{~m} / 100 \mathrm{~m}$

For $73 \mathrm{~m}$ length

$\mathrm{Hf}=0.68 \mathrm{~m}$ 


\begin{tabular}{|l|c|c|}
\hline Particulars & Unit & H.Zone1 \\
\hline Lateral Length & $\mathrm{m}$ & 73 \\
\hline Inside diameter & $\mathrm{mm}$ & 14.2 \\
\hline Pipe material & & $\mathrm{PE}$ \\
\hline Pipe friction coefficient & $\mathrm{m}$ & 150 \\
\hline Emitter spacing & Nos. & $\mathbf{2 . 2 9}$ \\
\hline No. of emitters & LPH & $\mathbf{3 2 . 0 0}$ \\
\hline Emitter flow rate & LPH & $\mathbf{2}$ \\
\hline Lateral flow rate & - & $\mathbf{2 5 6}$ \\
\hline Factor for multiple outlet & $\mathrm{m}$ & $\mathbf{0}$ \\
\hline Fittings loss for emitters & $\mathrm{m} / 100 \mathrm{~m}$ & $\mathbf{0 . 9}$ \\
\hline Head loss (Watter \& Keller) & $\mathrm{m} / 100 \mathrm{~m}$ & $\mathbf{0 . 7}$ \\
\hline Head loss (Hazzen Willam) & $\mathrm{m}$ & $\mathbf{0 . 6 8}$ \\
\hline Total lateral head loss, $\mathrm{h}_{\mathrm{f}}$ & $\mathrm{m} / \mathrm{sec}$ & $\mathbf{0 . 4 5}$ \\
\hline Velocity & & \\
\hline
\end{tabular}

Sub-Mainline Design:

Length $=100 \mathrm{~m}$

Sub-main flow rate $=93056 / 4$

=23,264 Iph

Assume $71.4 \mathrm{~mm}$ ID

Sub-Mainline

$\left.J=7.89^{*} 10^{\wedge} 7^{*}\left[(23264 / 3600)^{\wedge} 1.75\right) /\left(71.4^{\wedge} 4.75\right)\right] * 0.36$

$\mathrm{J}=1.21 \mathrm{~m} / 100 \mathrm{~m}$

For $100 \mathrm{~m}$ length

$\mathrm{Hf}=1.21 \mathrm{~m}$

Darcy- Weisbach and Blasius Equation can be combined to give accurate prediction of friction head loss for smooth plastic pipes of less than $125 \mathrm{~mm}$ (5 in.) diameter.

$$
\begin{array}{ll}
\mathrm{J}=100 \mathrm{hf} / \mathrm{L}=\mathrm{k}^{*}\left[\left(\mathrm{Q}^{\wedge} 1.75\right) /\left(\mathrm{D}^{\wedge} 4.75\right)\right] \\
\mathrm{J} & =\text { Head loss gradient, } \mathrm{m} / 100 \mathrm{~m} \\
\mathrm{Hf} & =\text { pipe friction head loss, } \mathrm{m} \\
\mathrm{K} & =\text { Constant, } 7.89 * 10^{\wedge} 7 \text { for metric units } \\
\mathrm{Q} & =\text { Flow Rate, LPS } \\
\mathrm{L} & =\text { Pipe length, } \mathrm{m} \\
\mathrm{D} & =\text { Inside Diameter of Pipe, } \mathrm{mm}
\end{array}
$$




\begin{tabular}{|l|c|c|}
\hline Particulars & Unit & H.Zone1 \\
\hline Sub-Mainline Length & $\mathrm{m}$ & 100 \\
\hline Inside diameter & $\mathrm{mm}$ & 71.4 \\
\hline Pipe material & & PVC \\
\hline Pipe friction coefficient & & 150 \\
\hline Lateral spacing & $\mathrm{m}$ & 2.29 \\
\hline No. of laterals operating & Nos. & 91 \\
\hline Lateral flow rate & LPH & 256 \\
\hline Sub-mainline flow rate & LPH & 23296 \\
\hline Factor for multiple outlet & - & 0.36 \\
\hline Head loss gradient (Watter \& Keller) & $\mathrm{m} / 100 \mathrm{~m}$ & 1.17 \\
\hline Head loss gradient (Hazzen Willam) & $\mathrm{m} / 100 \mathrm{~m}$ & 1.21 \\
\hline Total head loss, $\mathrm{h}_{\mathrm{f}}$ & $\mathrm{m}$ & 1.21 \\
\hline Velocity & $\mathrm{m} / \mathrm{s}$ & $\mathbf{1 . 6 2}$ \\
\hline
\end{tabular}

Mainline Design:

Length $=213 \mathrm{~m}$

Main-line flow rate $=23264 \mathrm{LPH}$

Assume 84.4 ID Mainline

$\left.\mathrm{J}=7.89^{\star} 10^{\wedge} 7^{*}\left[(23264 / 3600)^{\wedge} 1.75\right) /\left(84.4^{\wedge} 4.75\right)\right]$

$\mathrm{J}=1.46 \mathrm{~m} / 100 \mathrm{~m}$

For $213 \mathrm{~m}$ length

$\mathrm{Hf}=3.17 \mathrm{~m}$

$V=1.274 \times\left[\left(23264 /\left(1000^{*} 3600\right)\right] /\left[(84.4 / 1000)^{\wedge} 2\right]=1.16 \mathrm{~m} / \mathrm{s}\right.$

\begin{tabular}{|l|l|c|}
\hline \multirow{2}{*}{ Particular } & \multirow{2}{*}{ Unit } & Section \\
\cline { 3 - 3 } & & $\mathbf{1}$ \\
\hline Length & $\mathrm{m}$ & 213 \\
\hline Inside diameter & $\mathrm{mm}$ & 84.4 \\
\hline Pipe material & & PVC \\
\hline Pipe friction coefficient & & 150 \\
\hline Design capacity & $\mathrm{LPH}$ & $\mathbf{2 3 2 5 3}$ \\
\hline Head loss gradient (Watter \& Keller) & $\mathrm{m} / 100 \mathrm{~m}$ & 1.46 \\
\hline Head loss gradient (Hazzen Willam) & $\mathrm{m} / 100 \mathrm{~m}$ & 0 \\
\hline Mainline fittings losses & $\mathrm{M}$ & $\mathbf{1 . 4 9}$ \\
\hline Flow velocity & $\mathrm{m} / \mathrm{s}$ & 3.17 \\
\hline Total mainline head loss & $\mathrm{M}$ & \multicolumn{2}{|c|}{} \\
\hline
\end{tabular}

TOTAL DYNAMIC HEAD

- Emitter operating pressure

$=10 \mathrm{~m}$

- Head loss in lateral

$=0.68 \mathrm{~m}$

- Lateral Elevation

$=0 \mathrm{~m}$

- Head loss in submains

$=1.16 \mathrm{~m}$ 
- Head loss in Valve (assume $2 \mathrm{~m}$ )

- Field fitting head loss

- Head Loss in Main line

- Primary filter head loss (Gravel $20 \mathrm{~m} 3$ )

- Secondary filter head loss (Disc $20 \mathrm{m3}$ )

- Fertigation equipment head loss (5 $\mathrm{m}$ for ventury)

- Water source depth

- Suction head

- Delivery head

- Safety equipment head loss

- Elevation difference

- Other losses

- Total Head Required
$=2.0 \mathrm{~m}$

$=2.0 \mathrm{~m}$

$=3.12 \mathrm{~m}$

$=1.5 \mathrm{~m}$

$=1.3 \mathrm{~m}$

$=5 \mathrm{~m}$

$=0 \mathrm{~m}$

$=1 \mathrm{~m}$

$=1 \mathrm{~m}$

$=2 \mathrm{~m}$

$=0 \mathrm{~m}$

$=0 \mathrm{~m}$

$=30.76 \mathrm{~m}$

Say $31 \mathrm{~m}$

Total Flow Required $=23,264 \mathrm{~m} 3 / \mathrm{hr}=6.46 \mathrm{lps}$

Pump H.P $=\mathrm{Q}($ LPS $){ }^{*} \mathrm{H}(\mathrm{m}) /(75 \times$ pump efficiency $\mathrm{x}$ motor efficiency $)$

$$
=6.46 * 30.76 /(75 * 0.65 * 0.9)
$$

$=4.56$

Say 5 H.P

\begin{tabular}{|c|c|c|c|c|c|c|}
\hline S.N & Description & $\begin{array}{l}\text { Standard/ } \\
\text { specification }\end{array}$ & Unit & Quantity & Rate (Rs.) & Cost (Rs.) \\
\hline 1 & Pump set ( $20 \mathrm{HP})$ & $\mathrm{KSB} / \mathrm{MECO} / \mathrm{X}$ & No & 01 & 80,000 & 80,000 \\
\hline 2 & Gravel Filter $40 \mathrm{M} 3 / \mathrm{Hr}$ & $40 \mathrm{M} 3 / \mathrm{hr}$, Jain & & 02 & 40,000 & 80,000 \\
\hline$\overline{3}$ & Disc filters & \begin{tabular}{|l}
$40 \mathrm{M} 3 / \mathrm{hr}$ \\
Netafim
\end{tabular} & & 02 & 25,000 & 50,000 \\
\hline 4 & Ventury with assembly & & & 01 & 7,500 & 7,500 \\
\hline$\overline{5}$ & Flow Meter & $80 \mathrm{M} 3 / \mathrm{hr}$, Kitz & & 01 & 65,000 & 65,000 \\
\hline 6 & \begin{tabular}{|l|} 
Pressure Gauges \\
\end{tabular} & & & 05 & 1,100 & 5,500 \\
\hline 7 & Air Release valves & & & 02 & 1500 & 3,000 \\
\hline 8 & NRV & & & 01 & 15,000 & 1,500 \\
\hline$\overline{9}$ & \begin{tabular}{|l} 
Foot valve \\
\end{tabular} & & & 01 & 10,000 & 10,000 \\
\hline 10 & \begin{tabular}{|l} 
Flush valves (sub-main) \\
\end{tabular} & & & 02 & 3,000 & 6,000 \\
\hline 11 & GI Pipe & $110 \mathrm{~mm}$ & $\mathrm{~m}$ & 5 & 2,000 & 10,000 \\
\hline 12 & GI Fittings & $110 \mathrm{~mm}$ & $\mathrm{~L} / \mathrm{s}$ & 1 & 10,000 & 10,000 \\
\hline 13 & PVC Pipe, B Class & $160 \mathrm{~mm}$ & $\mathrm{~m}$ & 60 & 700 & 42,000 \\
\hline 14 & PVC Pipe, B Class & $110 \mathrm{~mm}$ & $\mathrm{~m}$ & 225 & 370 & 83,250 \\
\hline 15 & \begin{tabular}{|l|} 
Plain Lateral \\
\end{tabular} & $16 \mathrm{~mm}$ & $\mathrm{~m}$ & 500 & 20 & 10,000 \\
\hline 16 & Lateral line 21ph x 0.4 m spacing, wt $1.5 \mathrm{~mm}$ & $16 \mathrm{~mm}$ & $\mathrm{~m}$ & 18,000 & 25 & 450,000 \\
\hline 17 & GTO & & Nos. & 290 & 15 & 4,350 \\
\hline 18 & Lateral End Stop & & Nos. & 290 & 10 & 2,900 \\
\hline & Sub-Total & & & & & 921,000 \\
\hline & Service charges (Design, Installation, Service) & $8 \%$ of total & & & & $73,680 \quad 23$ \\
\hline \multicolumn{5}{|c|}{ Grand Total } & \multicolumn{2}{|l|}{994,680} \\
\hline
\end{tabular}




\section{Example Orchard-3}

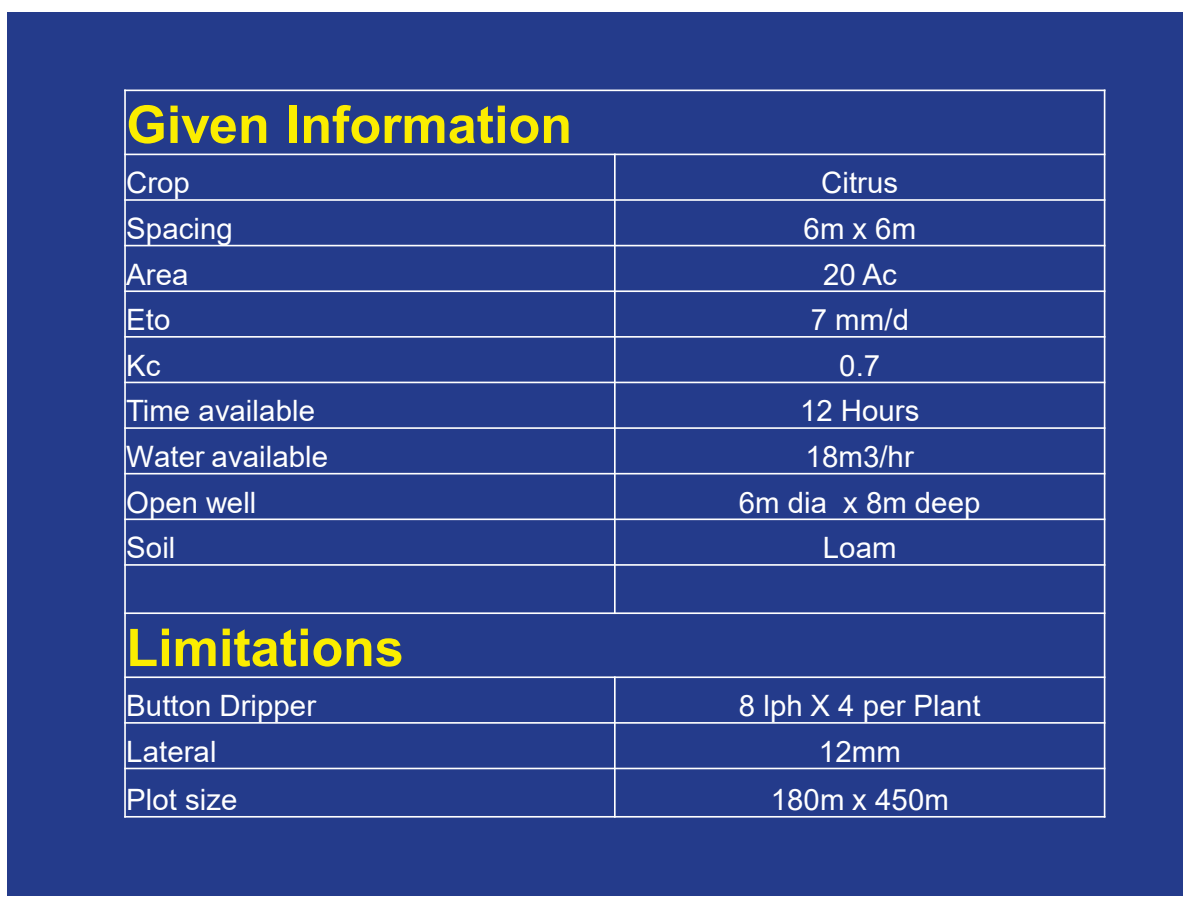

Total Area $=450 \times 180=81000 \mathrm{~m}^{2}$

$\mathrm{PWR}=$ Eto $\times \mathrm{Kc} \times$ canopy factor /efficiency

$$
=6 \times 0.7 \times 0.6 / 0.9=2.8 \mathrm{~mm} / \mathrm{d}
$$

Total drip line length $=$ Area $\times$ no. of drip lines per plant row $/$ (lateral spacing)

$$
=81000 \times 1 / 6=13500 \mathrm{~m}
$$

Total number of plants $=$ Area $/($ plant spacing $x$ row spacing $)$

$$
=(81000 /(6 \times 6)=2250
$$

Total number of emitters $=$ No. of plants $\times$ Dripper per plant

$$
=2250 \times 4=9000
$$

Total number of emitters $=$ No. of plants $\mathrm{x}$ Dripper per plant

$$
=2250 \times 4=9000
$$

Average emitter spacing $=13500 / 9000=1.5 \mathrm{~m}$

Total flow rate $=$ no. of emitters $x$ emitter flow rate

$$
=9000 \times 8 \mathrm{lph}=72,000 \mathrm{lph}
$$

Application Rate $=$ Flow rate $/$ area

$$
=72000 / 81000=0.89 \mathrm{~mm} / \mathrm{h}
$$

Operation time per day $=$ PWR/ Application Rate

$$
=2.8 / 0.89=3.15 \text { hours }
$$

Capacity of the water source is $18000 \mathrm{Iph}$, we will divide the area into shifts No. of shifts/hydro-zone $=72000 \mathrm{lph} / 18000 \mathrm{Iph}=4$

Wetted percentage $=$ 
no. of emitters $x$ Area wetterd by single emitter/plant Area

$$
\begin{aligned}
& =4 \times 4 /(6 \times 6) \\
& =44 \%
\end{aligned}
$$

If we go with 6 drippers per plant, then percent wetted area will result about $66 \%$.
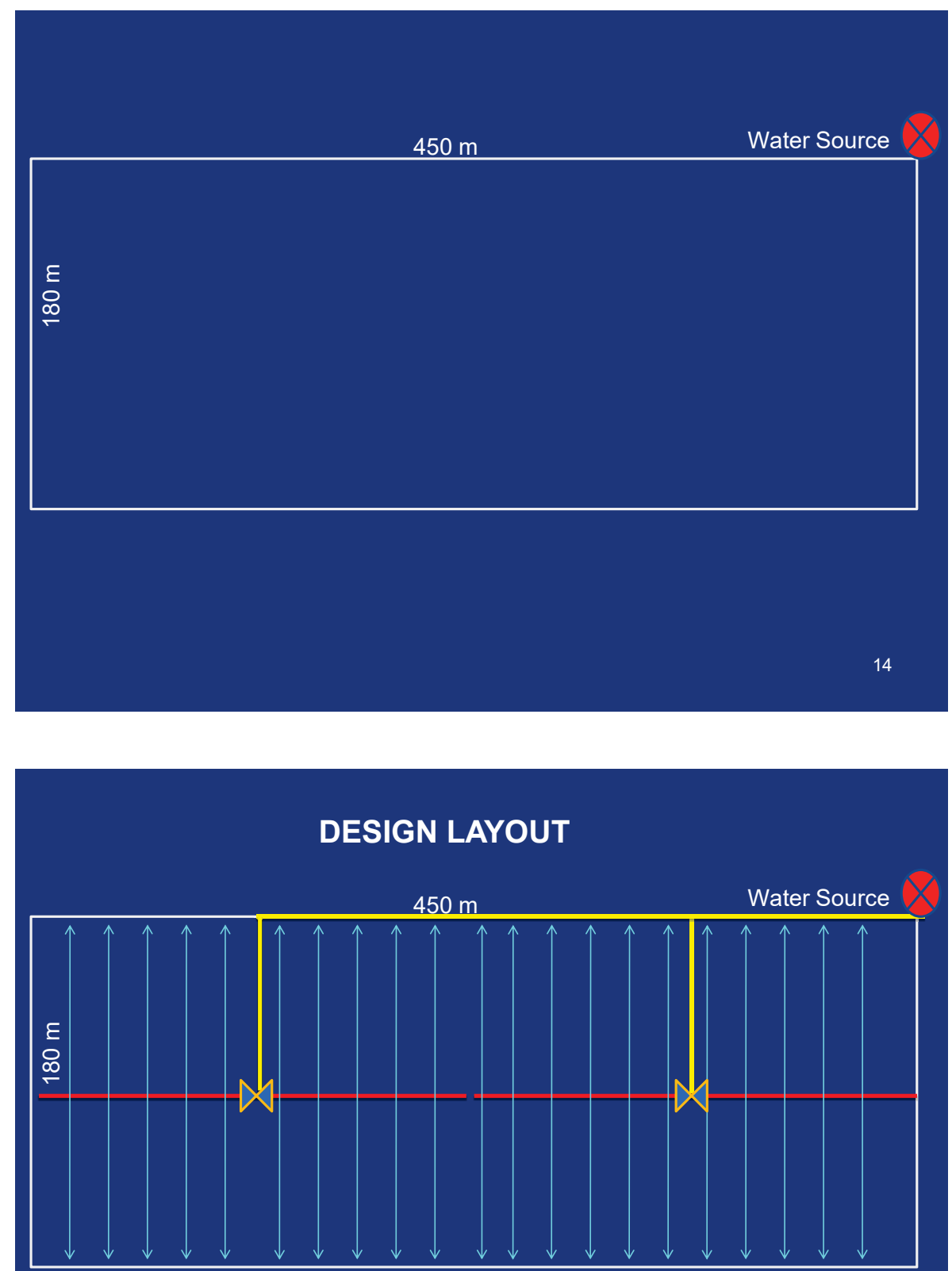


\section{A) Lateral Selection}

(12 $\mathrm{mm}$ OD WT $=0.9 \mathrm{~mm}$ )

Length, $\mathrm{m}=90 \mathrm{~m}$

Inside diameter, $\mathrm{mm}=10.2 \mathrm{~mm}$

Flow rate, $\mathrm{Iph}=(90 / 1.5)^{*} 8=480 \mathrm{Iph}$

Head loss using Hazzen-William Equation: $(6.1 \mathrm{~m} / 100 \mathrm{~m}=3.4$ meters $)$

PLZ CHECK CALCULATION

\section{B) Sub-Mainline Selection}

Length, $\mathrm{m}=112.5 \mathrm{~m}$

Inside diameter, $\mathrm{mm}=60.0 \mathrm{~mm}$

Flow rate, Iph $=\quad 18,000 \mathrm{Iph}$

Head loss using Hazzen-William Equation: $2.1 \mathrm{~m} / 100 \mathrm{~m}=2.34$ meters

\section{Mainline Selection}

Length, $\mathrm{m}=517.5 \mathrm{~m}$

Inside diameter, $\mathrm{mm}=68.0 \mathrm{~mm}$

Flow rate, Iph $\quad=\quad 18,000 \mathrm{Iph}$

Head loss using Hazzen-William Equation: $\quad 2.61 \mathrm{~m} / 100 \mathrm{~m}=11.72$ meters

Velocity $\quad=1.38 \mathrm{~m} / \mathrm{seconds}$

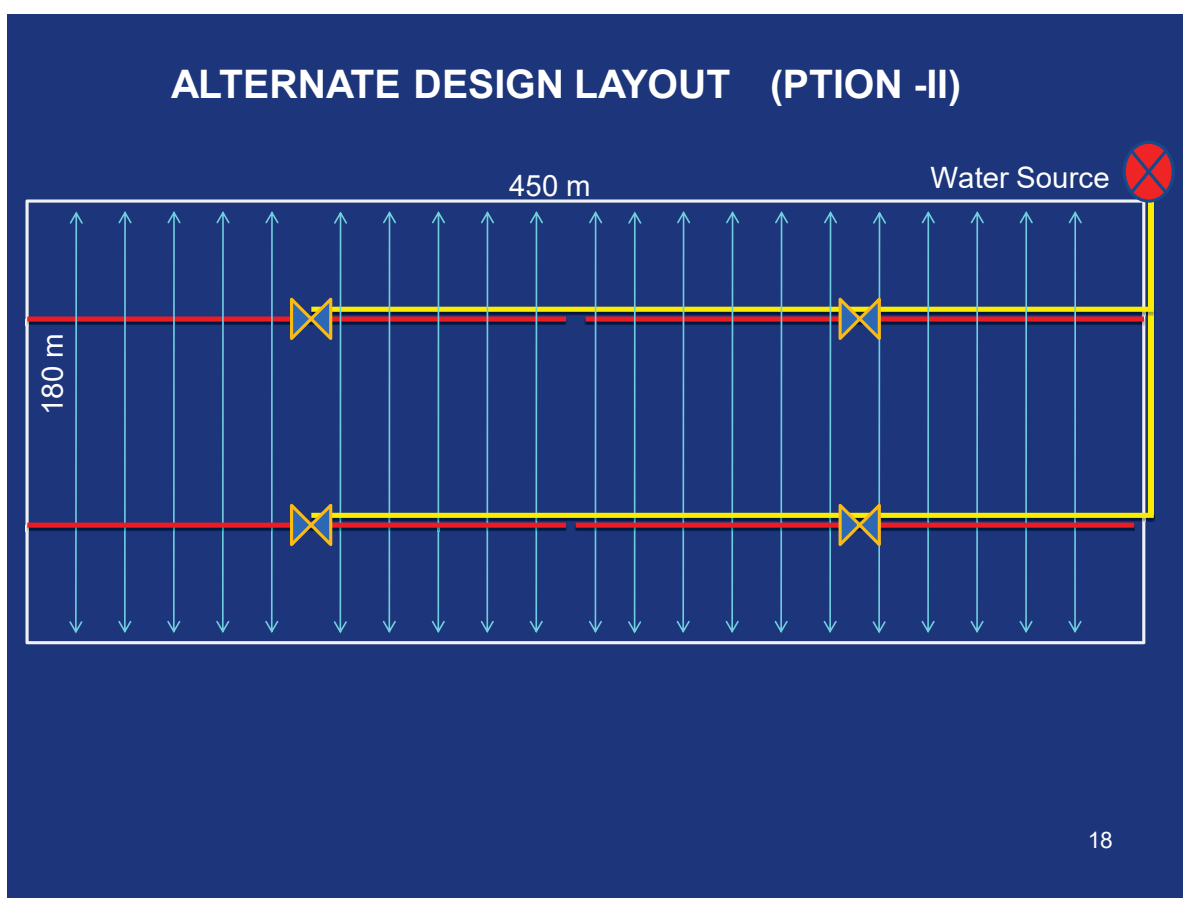




\section{A) Lateral Selection}

(12 $\mathrm{mm}$ OD WT $=0.9 \mathrm{~mm})$

Length, $\mathrm{m}=45 \mathrm{~m}$

Inside diameter, $\mathrm{mm}=10.2 \mathrm{~mm}$

Flow rate, $\mathrm{Iph}=(45 / 1.5)^{*} 8=240 \mathrm{Iph}$

Head loss using Hazzen-William Equation: $3.1 \mathrm{~m} / 100 \mathrm{~m}=1.4$ meters

\section{B) Sub-Mainline Selection}

Length, $\mathrm{m}=112.5 \mathrm{~m}$

Inside diameter, $\mathrm{mm}=60.0 \mathrm{~mm}$

Flow rate, $\mathrm{Iph}=\quad 18,000 \mathrm{Iph}$

Head loss using Hazzen-William Equation: $2.1 \mathrm{~m} / 100 \mathrm{~m}=2.34$ meters

\section{Mainline Selection}

Length, $\mathrm{m}=337.5 \mathrm{~m}$

Inside diameter, $\mathrm{mm}=68.0 \mathrm{~mm}$

Flow rate, $\mathrm{Iph}=\quad 18,000 \mathrm{Iph}$

Head loss using Hazzen-William Equation: $2.61 \mathrm{~m} / 100 \mathrm{~m}=11.72$ meters

Velocity $\quad=1.38 \mathrm{~m} /$ seconds

$\mathrm{TDH}=45 \mathrm{~m}$

$\mathrm{Q}=18000 \mathrm{Iph}$

H.P ?

\subsection{DRIP DESIGN PROCEDURE-STEP BY STEP (ROW CROP)}

Under the on-going project, drip systems are being installed on orchard and at row crops/vegetables. In this section, steps for designing a drip system for row crop will be discussed. The following are the design steps.

1. Collection of Basic Information

2. Estimation of Peak Water Requirement PWR

3. Drawing of project area, selection of zone area and No. of Operations

4. Selection of emitter/dripper, and flow rate

5. Calculation of total length of lateral No. of emitters in one zone and total No. of emitters

6. Calculation of Total Flow rate requirement $(Q)$

7. Calculation of Application Rate

8. Total Operational Time

9. Selection and Design of Lateral Line

10. Design of Sub-mainline

11. Design of Mainline

12. Head Loss through fittings

13. Selection of Filters and other equipment and head loss

14. Calculation of total dynamic head $(H)$

15. Calculation of required horsepower (HP)

16. Selection of Pumps and Motor

17. Preparation of Drawing

18. Preparation of Bill of Quantities 


\section{Step 1. Collection of Basic Information}

The following basic information be available before designing a drip irrigation system.

- General information: Name of farmer, village/chak No., tehsil, district, phone No.

- Land holding and Area spared for the project

- Engineering survey: GPS coordinates, Field measurement, Elevation difference/slope. After field measurement, a map showing all dimensions and location of water source be drawn

- Agricultural details: crops (orchard, row/field crop), spacing, type, age, reference evapotranspiration of the area and water requirement of crop

- Crop Spacing (Row to Row, Plant to Plant), sowing and harvesting date

- Soil Type/texture

- Soil and water analysis reports water quality, presence of iron, $\mathrm{pH}$, suspended particles, soil type, Ec, $\mathrm{pH}$

- Water Source, quantity, availability, location

- Power Source: Electric motor, diesel engine, tractor, solar system

- Climatologically data: temperature, humidity, rainfall, wind speed

- Peak Water Requirement: (ETo, Kc, Cf)

- Water source and Total Available Time of water

- System capacity: The system should have capacity adequate to fulfill daily crop water requirements of the area within a stipulated time or not more than 12 hours of operation per day (only for Pakistan circumferences, otherwise may be $22 \mathrm{hrs}$ ).

The basic information can be categorized as under.

I.

GENERAL INFORMATION

\begin{tabular}{|l|l|l|l|}
\hline Name of beneficiary & Town/Village/City & \\
\hline Tehsil & & District & \\
\hline Province & & Phone No. & \\
\hline Land holding (Acre) & Scheme area (acres) & \\
\hline Topography (Flat/Undulated) & & & \\
\hline
\end{tabular}

II. CROP INFORMATION

\begin{tabular}{|c|c|c|c|c|c|c|c|c|c|}
\hline \multicolumn{3}{|c|}{ Parameters } & Crop & 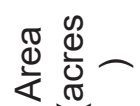 & $\begin{array}{l}+\frac{0}{0} \\
\frac{\pi}{\mathbb{N}} \\
\frac{\mathbb{D}}{\alpha} \\
\frac{0}{0}\end{array}$ & 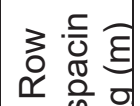 & 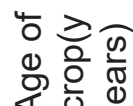 & $\cdot \frac{9}{3}$ & 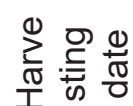 \\
\hline Block-I & $\begin{array}{l}\text { Row } \\
\text { Crop }\end{array}$ & Proposed & COTTON & 20 & 0.5 & 1.52 & & MARCH & NO \\
\hline
\end{tabular}

III.

EVAPOTRANSPIRATION AND CROP COEFFICIENTS (Etc \& Kc)

\begin{tabular}{|c|c|c|c|c|c|c|c|c|c|c|c|c|}
\hline Month & $\mathrm{J}$ & $\mathrm{F}$ & $\mathrm{M}$ & $\mathrm{A}$ & $\mathrm{M}$ & $\mathrm{J}$ & $\mathrm{J}$ & $\mathrm{A}$ & $S$ & 0 & $\mathrm{~N}$ & $\mathrm{D}$ \\
\hline Eto $(\mathrm{mm} / \mathrm{d})$ & 1.8 & 2.7 & 4 & 6.4 & 8.6 & 9.2 & 7.6 & 6.5 & 5.8 & 4.5 & 2.7 & 1.9 \\
\hline Kc (cotton) & & & & 0.5 & 0.8 & 1 & 1.29 & 1.2 & 0.9 & 0.7 & 0.7 & \\
\hline Crop factor at mat. & & & & 0.4 & 0.7 & 1 & 1 & 1.1 & 1 & 1 & 0.7 & \\
\hline Efficiency & & & & 0.9 & 0.9 & 0.9 & 0.9 & 0.9 & 0.9 & 0.9 & 0.9 & \\
\hline PCWR (cotton) & & & & 1.42 & 5.35 & 10.2 & 10.89 & 9.53 & 5.80 & 3.50 & 1.37 & \\
\hline Kc () & & & & & & & & & & & & \\
\hline Crop factor at mat. & & & & & & & & & & & & \\
\hline PCWR () & & & & & & & & & & & & \\
\hline Kc (field crops) & & & & & & & & & & & & \\
\hline CWR (field crops) & & & & & & & & & & & & \\
\hline
\end{tabular}




\section{SOIL TYPE/SOIL TEST/WATER SUPPLY/WATER QUALITY}

SOIL TEST

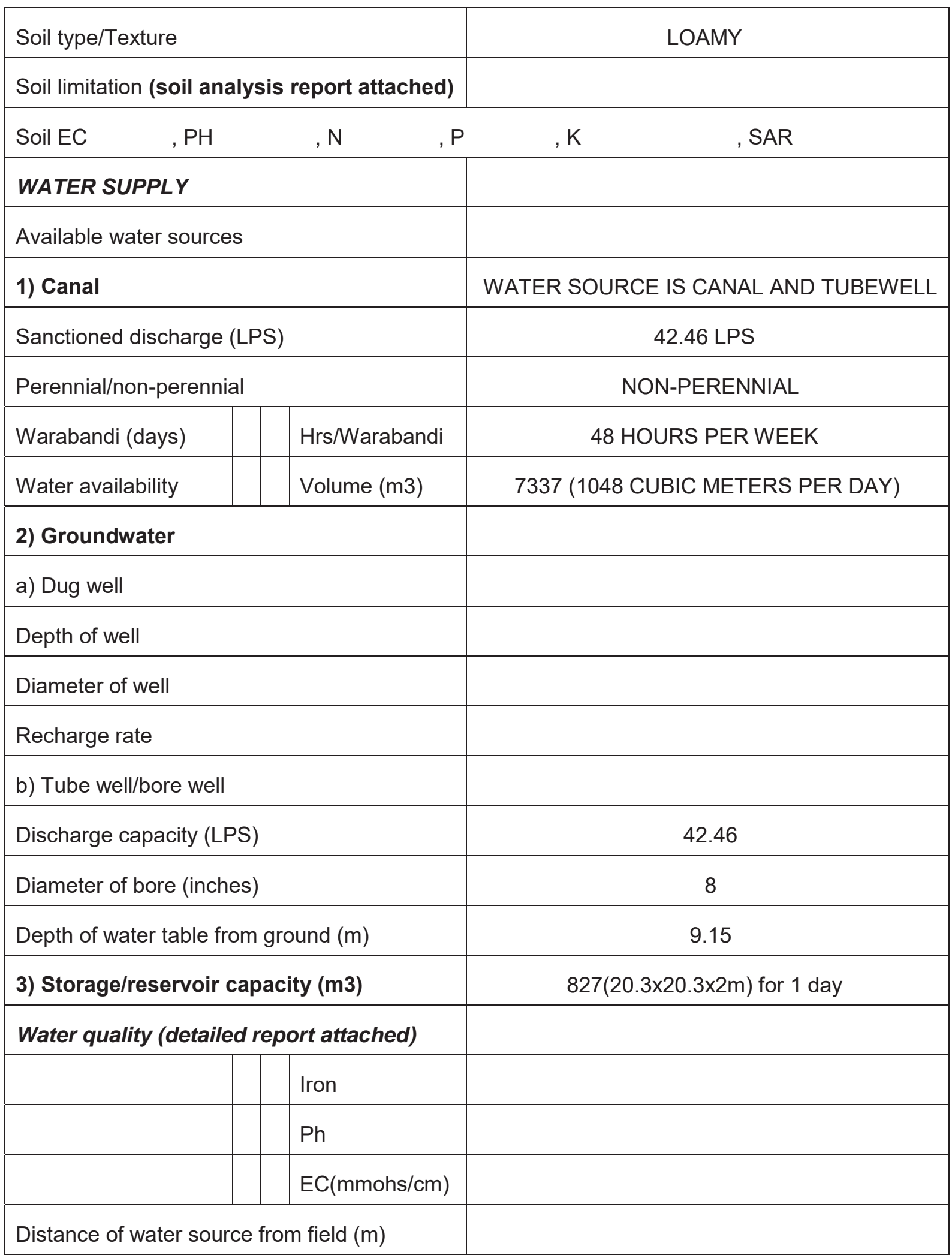


V. POWER SOURCE AND PUMP

\begin{tabular}{|l|l|}
\hline POWER SOURCE & \\
\hline Type of power to be used & \\
\hline $\begin{array}{l}\text { For electric Motor, } \\
\text { Type of connection (single/3-phase) }\end{array}$ & \\
Make/model & \\
HP of Motor & \\
RPM of Motor & \\
\hline $\begin{array}{l}\text { For diesel engine } \\
\text { Make }\end{array}$ & \\
HP & ELECTRICITY NOT AVAILABLE \\
Condition) & \\
\hline For Tractor & \\
Make/model & \\
HP & \\
Condition & \\
\hline Any other power source, if any & \\
\hline PUMP SET & \\
\hline $\begin{array}{l}\text { Type } \\
\text { Make/Model } \\
\text { Pressure (ft/psi/bar) } \\
\text { Flow(lps) }\end{array}$ & \\
Inlet/outlet size & \\
PPM & \\
\hline
\end{tabular}




\section{Water Analysis Report}

\begin{tabular}{|c|c|c|c|c|c|}
\hline \multirow{2}{*}{\multicolumn{2}{|c|}{$\begin{array}{ll}\text { Farmer Name } & \text { : Abbass Qureshi } \\
\text { Address } & \text { :Muzaffar garh }\end{array}$}} & & & \multirow{3}{*}{$\begin{array}{c}\text { Tube Well } \\
10 / 5 / 2010 \\
13 / 05 / 2010\end{array}$} \\
\hline & & & Sampling Date & & \\
\hline Ph :0345-8644888 & & & $\begin{array}{l}\text { Sp Receive Date } \\
:\end{array}$ & & \\
\hline \multicolumn{2}{|c|}{$\begin{array}{l}\text { Agronomist: Ather Mehmood } \\
\text { Khursheed }\end{array}$} & & Report Date & & $31 / 05 / 2010$ \\
\hline & & & Ref.Sample & \# & 372 \\
\hline \multirow[b]{2}{*}{ Parameters } & \multicolumn{4}{|c|}{ Degree of Presence / Problem } & \\
\hline & Unit & $\begin{array}{c}\text { Noma } \\
1\end{array}$ & Higher & $\begin{array}{c}\text { Extrem } \\
\mathrm{e}\end{array}$ & Result \\
\hline $\mathrm{pH}$ & & 7 & $<7$ Acidic & $>7 \mathrm{~A}$ & 7.37 \\
\hline $\begin{array}{l}\text { Electrical Conductivity } \\
\text { (Salinity) }\end{array}$ & microsemens/cm & - & - & - & 2240 \\
\hline Total dissolved solids & $\mathrm{ppm}$ & $<500$ & $500-600$ & $>600$ & 1290 \\
\hline Hardness & ppm & $<200$ & $200-300$ & $>300$ & 312 \\
\hline Calcium & ppm & $<60$ & $60-100$ & $>100$ & 78.4 \\
\hline Magnesium & ppm & $<25$ & $25-40$ & $>40$ & 28.21 \\
\hline Carbonate & ppm & $<200$ & $200-600$ & $>600$ & 72 \\
\hline Bicarbonate & ppm & $<200$ & $200-600$ & $>600$ & 176 \\
\hline Chloride (Toxic) & $\mathrm{ppm}$ & $<140$ & $140-350$ & $>350$ & 198.5 \\
\hline Sulphates & ppm & $<20$ & $20-50$ & $>50$ & 23.4 \\
\hline Sodium & $\mathrm{ppm}$ & $<100$ & $100-200$ & $>200$ & 235 \\
\hline SAR & - & $<3$ & $3-9$ & $>9$ & 2 \\
\hline Potassium & ppm & $<10$ & $10-20$ & $>20$ & 12 \\
\hline Sulphides & ppm & $<15$ & $15-25$ & $>25$ & - \\
\hline Iron & ppm & $<0.1$ & $0.1-0.4$ & $>0.4$ & 0.1 \\
\hline Manganese & $\mathrm{ppm}$ & $<0.2$ & $0.2-0.4$ & $>0.4$ & - \\
\hline Suspended solids & ppm & $<10$ & $10-100$ & $>100$ & 7.1 \\
\hline Boron & ppm & $<0.5$ & $0.5-2.0$ & $>2.0$ & - \\
\hline
\end{tabular}


Soil Analysis Report

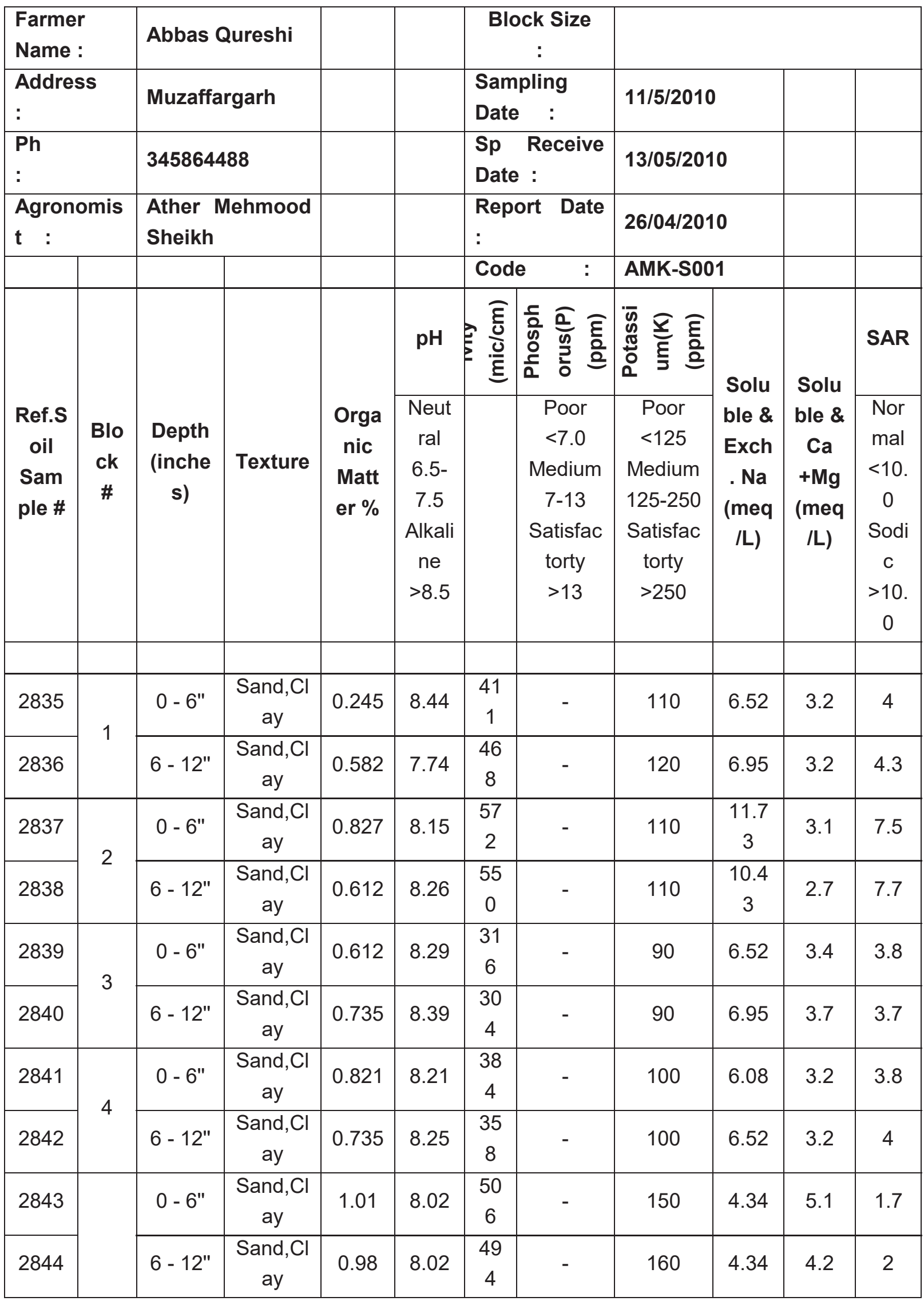




\begin{tabular}{|c|c|c|c|c|c|c|c|c|c|c|c|}
\hline 2845 & \multirow{2}{*}{6} & 0 - 6" & $\begin{array}{c}\text { Sand,Cl } \\
\text { ay }\end{array}$ & 1.041 & 8.05 & $\begin{array}{c}41 \\
2\end{array}$ & - & 120 & 4.34 & 4.2 & 2 \\
\hline 2846 & & $6-12 "$ & $\begin{array}{c}\text { Sand, Cl } \\
\text { ay }\end{array}$ & 0.919 & 8.11 & $\begin{array}{c}35 \\
6\end{array}$ & - & 100 & 4.34 & 4.2 & 2 \\
\hline 2847 & \multirow{2}{*}{7} & 0 - 6" & $\begin{array}{c}\text { Sand, Cl } \\
\text { ay }\end{array}$ & 0.919 & 7.97 & $\begin{array}{l}10 \\
80\end{array}$ & - & 80 & $\begin{array}{c}10.8 \\
6\end{array}$ & 6.6 & 3.2 \\
\hline 2848 & & $6-12 "$ & $\begin{array}{c}\text { Sand,Cl } \\
\text { ay }\end{array}$ & 0.549 & 8.02 & $\begin{array}{l}11 \\
23\end{array}$ & - & 80 & $\begin{array}{c}11.7 \\
3\end{array}$ & 5.8 & 4 \\
\hline
\end{tabular}

It is advisable to make rough map of the area and mark salient features, divide the drawn map into different blocks and number the same for soil and water sampling. This map will be finalized during designing of drip irrigation system and will show all necessary details including drippers, dia, length and location of laterals, submain and main, location of water source, power source etc.,

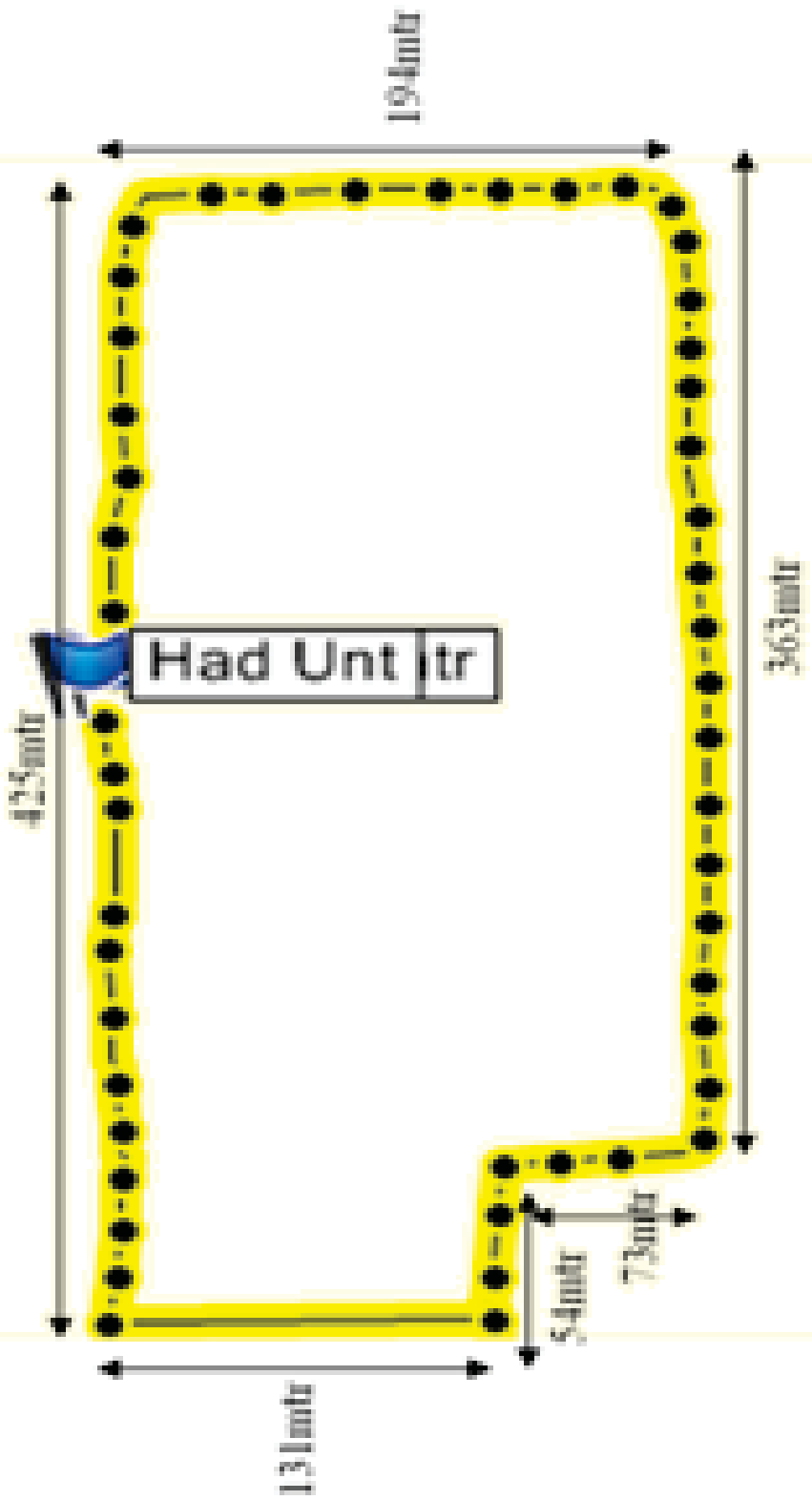




\section{Step 2. Estimation of Peak Crop Water Requirement}

Estimating the reference crop evapotranspiration (ETo), using the Penman-Monteith method, and the crop evapotranspiration (ETc), through the use of the appropriate crop factor $\mathrm{Kc}$, have been covered in Module 4 Chapter of this Manual. Evapo-transpiration is composed of the evaporation from the soil and the transpiration of the plant. Since under localized irrigation only a portion of the soil is wetted, the evaporation component of evapotranspiration can be reduced accordingly, using the appropriate ground cover reduction factor $\mathrm{Kr}$.

For the design of surface and sprinkler irrigation systems:

$$
\mathrm{ETc}=\mathrm{ETo} \times \mathrm{Kc}
$$

\section{For the design of Drip irrigation systems:}

Water Requirements for Orchard ETc= ETo $\times$ Kc $\times$ Canopy Factor/ Efficiency

Percent area wetted, $100 \%$ for closely spaced crops with rows and emitter lines less than $1.8 \mathrm{~m}$.

Peak Crop Water Requirement can be tabulated as under.

\begin{tabular}{|c|c|c|c|c|c|c|c|c|c|c|c|c|}
\hline Month & $\mathbf{J}$ & $\mathbf{F}$ & $\mathbf{M}$ & $\mathbf{A}$ & $\mathbf{M}$ & $\mathrm{J}$ & $\mathrm{J}$ & $\mathbf{A}$ & $\mathrm{S}$ & 0 & $\mathbf{N}$ & D \\
\hline Eto $(\mathrm{mm} / \mathrm{d})$ & 2.1 & 2.7 & 4.2 & 5.6 & 7 & 7.9 & 7.3 & 6.8 & 5.9 & 4.8 & 3.3 & 2.3 \\
\hline Kc (citrus) & 0.7 & 0.7 & 0.7 & 0.7 & 0.7 & 0.7 & 0.7 & 0.7 & 0.7 & 0.7 & 0.7 & 0.7 \\
\hline & & 0.5 & 0.5 & 0.5 & 0.5 & & 0.5 & 0.5 & 0.5 & 0.5 & & \\
\hline Crop factor at mat. & 0.57 & 7 & 7 & 7 & 7 & 0.6 & 7 & 7 & 7 & 7 & 0.6 & 0.57 \\
\hline Efficiency & 0.9 & 0.9 & 0.9 & 0.9 & 0.9 & 0.9 & 0.9 & 0.9 & 0.9 & 0.9 & 0.9 & 0.9 \\
\hline & & 1.2 & 1.8 & 2.4 & 3.1 & 3.5 & 3.2 & 3.0 & 2.6 & 2.1 & 1.4 & \\
\hline PCWR (citrus) & 0.93 & 0 & 6 & 8 & 0 & 0 & 4 & 1 & 2 & 3 & 6 & 1.02 \\
\hline Kc (mango) & 1.1 & 1.1 & 1.1 & 1.1 & 1.1 & 1.1 & 1.1 & 1.1 & 1.1 & 1.1 & 1.1 & 1.1 \\
\hline & & 0.5 & 0.5 & 0.5 & 0.5 & & 0.5 & 0.5 & 0.5 & 0.5 & & \\
\hline Crop factor at mat. & 0.55 & 5 & 5 & 5 & 5 & 0.6 & 5 & 5 & 5 & 5 & 0.6 & 0.55 \\
\hline & & 1.8 & 2.8 & 3.7 & 4.7 & 5.3 & 4.9 & 4.5 & 3.9 & 3.2 & 2.2 & \\
\hline PCWR (mango) & 1.41 & 2 & 2 & 6 & 1 & 1 & 1 & 7 & 7 & 3 & 2 & 1.55 \\
\hline \multicolumn{13}{|l|}{ Kc (field crops) } \\
\hline CWR (field crops & & & & & & & & & & & & \\
\hline
\end{tabular}

\section{Step 3. Drawing of Project Area, Selection of zone area and No. of Operations}

A map of the scheme area be drawn and tentative number of zones having equal area of the project be selected to estimate number of operations. It is advisable that area of each of each zone must be equal so that all the discharge coming out from the pump be fully utilized in each zone area. In case all zones are not equal, some additional water has to be sent back to the water storage tank through bypass valve during irrigation of small area zones. 


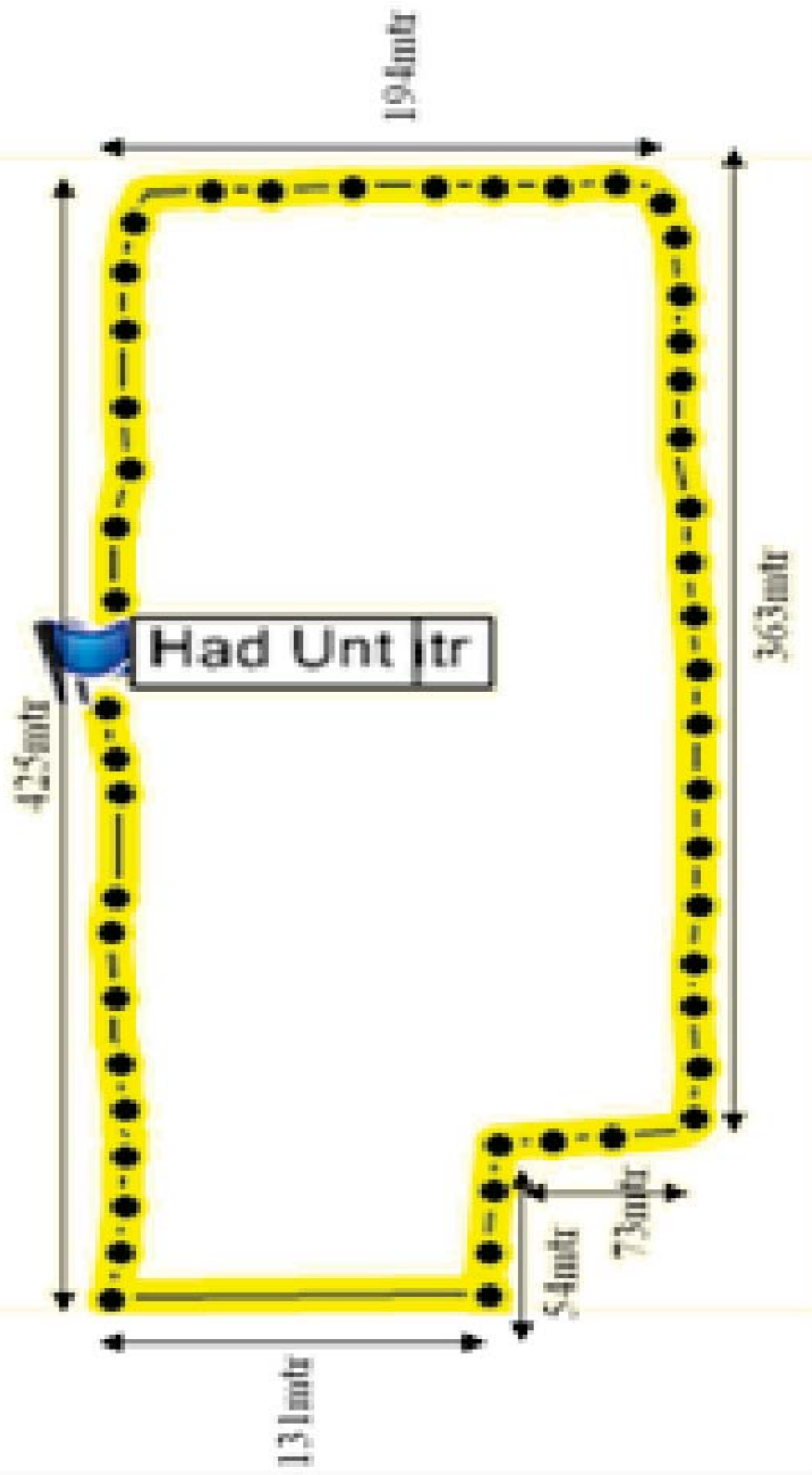




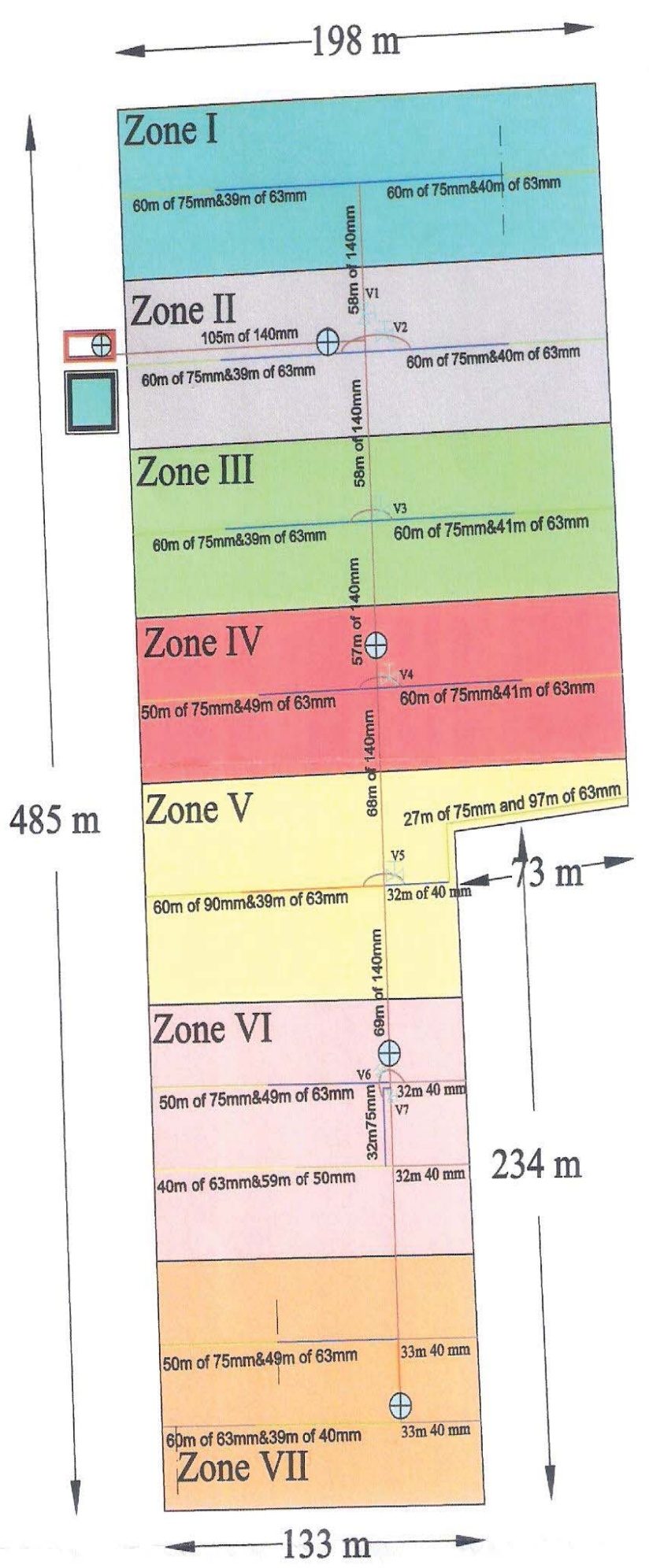

Zone \# 1 to 7

$12 \mathrm{~mm}$ lateral;Spacing $5 \mathrm{ft}$ 4lph, $50 \mathrm{~cm}$ emitter spacing Crop: Cotton

Area: 20Acre

Flow: 16.86lps

Irrigation Time: $1 \mathrm{hrs} 45 \mathrm{~min}$
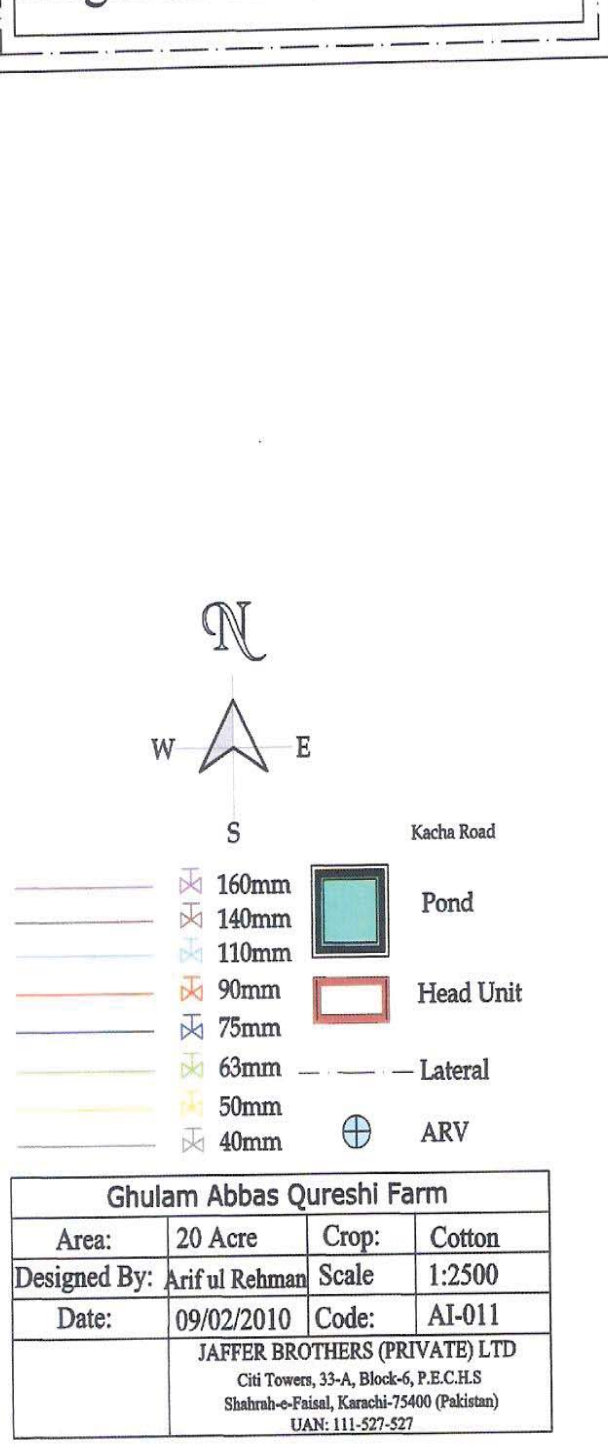


\section{Step 4. Selection of Emitter/Dripper and Flow Rate}

Varieties of drippers/drip tubing are available with different discharge rates, dripper spacing, characteristics and suitability for different crops. The emitter selected for the drip system:

- Should be Inexpensive, durable and serviceable

- Should have relatively low discharge rate to keep the system cost low

- Should have higher emission uniformity (90\%) and low coefficient of variation (CV $5 \%$ )

- Should have emission discharge exponent in the range of 0.4-0.7.

- Should have relatively large cross sectional area and flow path to avoid clogging

- Should have turbulent flow path and pressure compensation action

- Should not create runoff within the immediate application area

Drippers are available for 2, 4, 8 and 12 LPH discharge. Emitter operating pressure is usually $10 \mathrm{~m}$. The shape of the wetted zone of the emitter depends on the physical properties

\begin{tabular}{|l|c|}
\hline $\begin{array}{l}\text { In sandy and light soil, the water will tend to go straight } \\
\text { down, and there will be less lateral movement as compared } \\
\text { to downward movement. In light soils, the distribution of the } \\
\text { water will be narrow and deeper }\end{array}$ & $\begin{array}{c}\text { (close spaced low discharged } \\
\text { emitters/Closer emitter spacing) }\end{array}$ \\
\hline $\begin{array}{l}\text { In loamy soil, the water will move slowly and will spread } \\
\text { evenly }\end{array}$ & $\begin{array}{c}\text { (average discharged emitter \&/or } \\
\text { Spacing) }\end{array}$ \\
\hline $\begin{array}{l}\text { In clay soil, the water will be absorbed very slowly and } \\
\text { there will be more lateral movement as compared to } \\
\text { downward movement. In heavy soil, the distribution of the } \\
\text { water will be relatively spherical shape, wider and less } \\
\text { depth. }\end{array}$ & wider emitter spacing \\
\hline
\end{tabular}
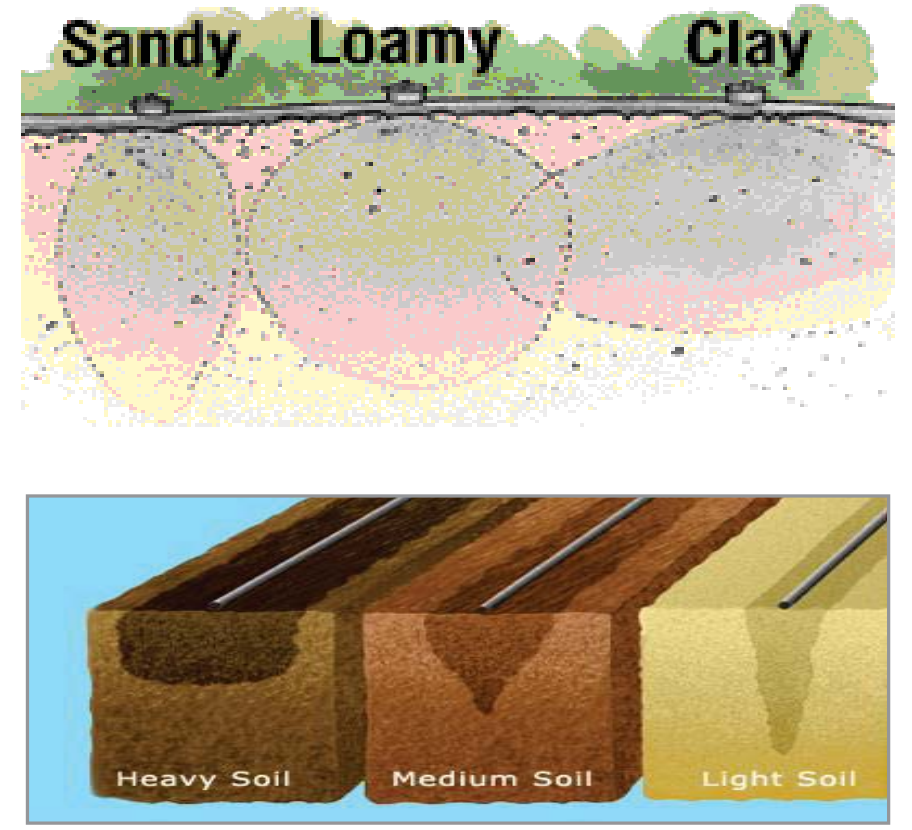


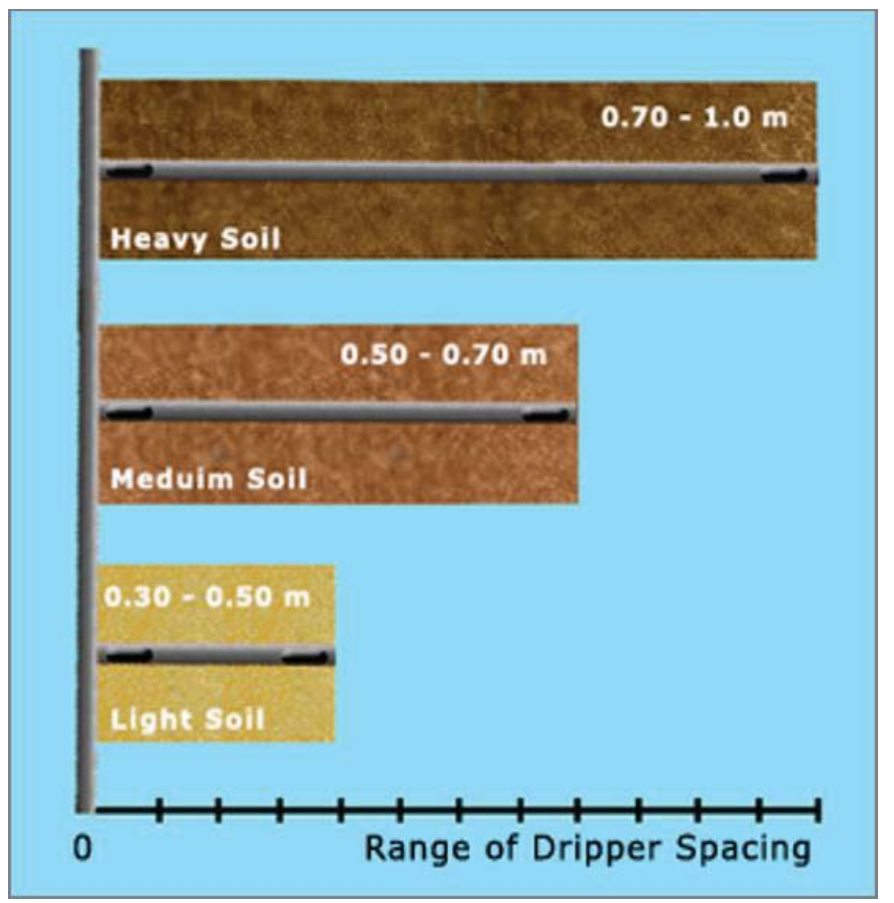

- Heavy soil recommended distance: 0.50 to 1.00 meter*

- Medium soil recommended distance: 0.40 to 0.75 meter*

- Light soil recommended distance:

- 0.20 to 0.50 meter*

- *The spacing between drippers depend on the root depth of the crop.

Emitter spacing should be maximum $0.5 \mathrm{~m}, 0.4-0.6$ and $0.5-0.8 \mathrm{~m}$ in light, medium and heavy soil respectively.

Most of the water emitter flow regime is fully turbulent with an exponent value equal to 0.5 . In order to ensure a high uniformity of water application over the field, the differences in the discharge of the emitters should be kept to the minimum possible and in no case exceed 10 percent. These criteria were established by J. Christiansen for sprinklers and are now applied in all pressurized systems. As a general rule, the maximum permissible difference in pressure between any two emitters in operation should be no more than 20 percent. The lateral lines with emitters must be of a size that does not allow a loss of head (pressure) due to friction of more than 20 percent. In case emitter operating pressure is 01 bar or 10 meter, the head loss in the selected lateral must not be more than 02 meter.

\section{Step 7. Calculation Of Total Length Of Lateral, Number Of Emitters In One Zone And Total Number Of Emitters}

The length of lateral required for the scheme area under micro irrigation system can be calculated as follows: 
Row Crops: Single Lateral per plant row

$$
\mathrm{L} \quad=\quad \mathrm{K} . \mathrm{A} \cdot / \mathrm{Ls}
$$

$\mathrm{K}=4047$

A $\quad=\quad$ Area (acres)

$\mathrm{L} \quad=\quad$ Lateral length $(\mathrm{m})$

Ls $\quad=\quad$ Lateral spacing, $\mathrm{m}$

Similarly, lateral length for sprinkler system can be calculated as

$$
\mathrm{L}=\mathrm{A} \times \mathrm{K} / \mathrm{LS}
$$

\section{TOTAL NUMBER OF EMITTERS}

Total no. of emitters in a scheme area or in a zone, can be calculated using following relationship.

\section{Row crops:}

Total number of emitters $\mathbf{e}=\quad$ Total lateral length $/$ Emitter spacing

\section{Step 8. Calculation of total flow rate requirements (Iph)}

For micro irrigation system, total flow rate required for the hydro-zone and/or scheme area can be calculated using the following relationships.

For Row Crops:

$$
\begin{aligned}
& \mathbf{Q}=\mathrm{e} \times \mathbf{q} \\
& \mathbf{Q}=L \times q \times S_{e}
\end{aligned}
$$

Where

$\mathrm{e} \quad=$ Total number of emitters

$\mathrm{q}=$ Emitter flow rate

$\mathrm{L} \quad=$ Lateral length

Se $\quad=$ Emitter spacing

$\mathrm{Q} \quad=$ Total flow rate

\section{Step 9. Calculation of application rate $(\mathrm{mm} / \mathrm{hr})$}

Application rate is the depth of water uniformly distributed over the entire scheme area and can be estimated using following relationship. 


\section{$I=Q / A$}

I $=$ Application Rate $(\mathrm{mm} / \mathrm{hr})$

$\mathrm{Q}=$ Total flow rate, $\mathrm{Lph}$

$\mathrm{A} \quad=\quad$ Area, $\mathrm{m}^{2}$

\section{Step 10. Total operation time (hrs)}

Operation time required to provide irrigation depth to meet daily consumptive use can be estimated using following relationship. The same relationship can be applied for both the Micro Irrigation system and sprinkler irrigation system.

\section{$\mathrm{T}=\mathrm{Cu} / \mathrm{I}$}

$\mathrm{T}=\quad$ Daily Operation time, hrs

\section{EXAMPLE ROW CROP:}

ETo $\mathrm{mm} /$ day $\quad: 7.6$

$\mathrm{Kc}$

$: 1.29$

Canopy factor $\quad: 1$

Plant spacing $\mathrm{m} \quad: 0.5$

Row Spacing m : 0.5

Emitter Flow Rate $\quad: 4 \mathrm{LPH}$

Calculate Design Steps from 1-8

Solution: 
Table indicates calculation of all parameters.

\begin{tabular}{|c|c|c|c|c|c|c|}
\hline Sr. No. & Description & Formulas & & Unit & $\begin{array}{c}\text { Zone } \\
\text { I to } \\
\text { VII }\end{array}$ & Total \\
\hline 1 & Area & & $A$ & $\mathrm{~m} 2$ & 80940 & 80940 \\
\hline 2 & Total Area under HEIS & & & ac & 20.00 & 20.00 \\
\hline \multirow[t]{3}{*}{3} & Avg. Sectional Area & & & ac & 2.86 & \\
\hline & Avg. Sectional Area & & & $\mathrm{m} 2$ & 11563 & \\
\hline & No. of zones & & & Nos. & 7 & 7.00 \\
\hline 4 & Lateral dia & & B & $\mathbf{m m}$ & 12 & 12 \\
\hline 5 & Emitter flow rate & & C & Iph & 4 & 4 \\
\hline 6 & Emitter Spacing & & $\mathrm{D}$ & $\mathrm{m}$ & 0.5 & 0.5 \\
\hline \multirow[t]{6}{*}{7} & Lat-Lat Spacing & & $\mathrm{H}$ & $\mathrm{m}$ & 1.52 & 1.52 \\
\hline & \multicolumn{2}{|l|}{ No. of crop rows per drip line } & & & 2 & \\
\hline & \multicolumn{2}{|l|}{ Irrigation cycle } & & & 1 & \\
\hline & Allowable HL in Lateral & & & $\mathbf{m}$ & 2 & 2 \\
\hline & Internal Diameter of lateral & & & $\mathrm{mm}$ & 10.7 & 10.7 \\
\hline & Max. Permissible Length & & & $\mathbf{m}$ & 38 & 38 \\
\hline 8 & \multicolumn{2}{|c|}{ Design reference evapo-transpiration (Eto) } & Eo & $\mathrm{mm} /$ day & 7.6 & \\
\hline 9 & \multicolumn{2}{|c|}{ Design crop factor at maturity (Kc) } & $F$ & ratio & 1.29 & \\
\hline \multirow[t]{2}{*}{10} & Canopy factor $\mathrm{Cf}$ & & G & ratio & 1 & 1 \\
\hline & Shaded area & & & & $100 \%$ & \\
\hline 11 & Irrigation Efficiency & & Ef & $\%$ & $90 \%$ & $90 \%$ \\
\hline 12 & $\begin{array}{l}\text { Peak Water Requirement } \\
\text { PWR(peak daily } \\
\text { consumptive use per day) }\end{array}$ & $\mathrm{I}=\mathrm{Eo}{ }^{*} \mathrm{Kc}{ }^{*} \mathrm{Cf} / \mathrm{Ef}$ & $\mathrm{I}=\mathrm{Eo} \mathrm{F}^{\star} \mathrm{G} / \mathrm{Ef}$ & $\mathrm{mm} /$ day & 10.89 & \\
\hline
\end{tabular}




\begin{tabular}{|c|c|c|c|c|c|c|}
\hline $\begin{array}{l}\text { Sr. } \\
\text { No. }\end{array}$ & Description & Formulas & & Unit & $\begin{array}{l}\text { Zone I } \\
\text { to VII }\end{array}$ & Total \\
\hline 14 & Total No. of Emitters & $\begin{array}{c}=\text { Area/lat-lateral } \\
\text { spacing }{ }^{\star} \text { Emitter } \\
\text { spacing }\end{array}$ & $M=L / D$ & Nos. & 15214 & $\begin{array}{c}10650 \\
0 \\
\end{array}$ \\
\hline \multirow[t]{3}{*}{15} & Total Flow & $\begin{array}{c}=\text { Area*emitter flow } \\
\text { rate/lat-lateral } \\
\text { spacing*Emitter } \\
\text { spacing }\end{array}$ & $\mathrm{N}=\mathrm{M}^{*} \mathrm{C}$ & Iph & 60857 & \\
\hline & & & & Ips & 16.90 & \\
\hline & $\begin{array}{c}\text { Application } \\
\text { Rate(method-1) }\end{array}$ & Total flow/total area & & $\mathrm{mm} / \mathrm{hr}$ & 5.26 & \\
\hline 16 & $\begin{array}{c}\text { Application } \\
\text { Rate(method-2) }\end{array}$ & $\begin{array}{c}=\text { Emitter flow rate/(lat- } \\
\text { lat spacing * emitter } \\
\text { spacing) }\end{array}$ & $\begin{array}{c}\mathrm{O}=\mathrm{C} /\left(\mathrm{H}^{*} \mathrm{D}\right. \\
)\end{array}$ & $\mathrm{mm} / \mathrm{hr}$ & 5.26 & 5.26 \\
\hline \multirow[t]{2}{*}{17} & Duration per operation & $\begin{array}{c}=\text { Peak water } \\
\text { requirement/applicatio } \\
\mathrm{n} \text { rate) }\end{array}$ & $\mathrm{P}=\mathrm{I} / \mathrm{O}$ & hrs & 2.07 & 0.00 \\
\hline & $\begin{array}{l}\text { No. of } \\
\text { zones/operations }\end{array}$ & & & Nos. & 7 & 7 \\
\hline 18 & Total Irrigation Time & & $Q=P * J$ & hrs & 14.49 & 0.00 \\
\hline 19 & Flow Per Operation & $=$ Total flow/\# of zones & $\mathrm{R}=\mathrm{N} / \mathrm{J}$ & $\mathrm{m} 3 / \mathrm{hr}$ & 8.69 & 60.86 \\
\hline 20 & Flow Per Operation & & & Ips & 2.41 & 16.90 \\
\hline 21 & Flow Per Operation & & & IGPM & 31.92 & 223.41 \\
\hline 22 & $\begin{array}{l}\text { Vol. of water } \\
\text { req./operation/day }\end{array}$ & & & $\mathrm{m} 3$ & $\begin{array}{r}125.9 \\
6 \\
\end{array}$ & 882 \\
\hline
\end{tabular}

Questions: 1. Is total irrigation time per day is less than 12 hours

2. Do we have required volume of water per day

\section{If yes $\mathrm{OK}$}

If no
Reduce area and repeat the design process

\subsection{Selection and Design of Lateral Line}

Laterals are available in different sizes i.e. $12 \mathrm{~mm}, 16 \mathrm{~mm}$ and $20 \mathrm{~mm}$. Head loss in the lateral length between the first and last emitter should not exceed by $20 \%$ of the head available at the first emitter to keep flow variation within $10 \%$ so as $90 \%$ of application uniformity can be achieved.

The design of lateral pipe involves selection of required pipe size for a given length which can require quantity of water to the plant. This is the most important component of the system as large amount of pipe per unit of land is required and the pipe cost is such that system is economically viable.

In designing the lateral, the discharge and operating pressure at emitters are required to be known and accordingly, the allowable pressure drop can be determined by the same formula as the main line. The total friction head loss in lateral can be calculated by multiplying the head loss over the total length by a factor $F$ given in Table $\mathbf{5 . 2}$. 


\section{Lateral Head loss $=$ hf $x \mathrm{~F}$}

Criteria: Allowable pressure drop in sub-mainline and laterals depends upon the operating pressure required at emitters. The pressure difference between the proximate and distant point along the supply line should not exceed $20 \%$ which will keep the variation of discharge within $10 \%$ of its value at the first emitter. The emitter operating pressure is usually $10 \mathrm{~m}$, therefore, the maximum allowable head loss in a lateral should be less than $20 \%$ of emitter operating pressure i.e. $2 m$.

Table 5.2 Reduction Coefficient 'F' for Multiple Outlet Pipeline Friction Loss

\begin{tabular}{|c|c|c|c|}
\hline No. of outlets & $\mathbf{F}$ & No. of outlets & $\mathbf{F}$ \\
\hline 1 & 1 & 8 & 0.42 \\
\hline 2 & 0.65 & 10 to 11 & 0.41 \\
\hline 3 & 0.55 & 12 to 15 & 0.40 \\
\hline 4 & 0.50 & 16 to 20 & 0.39 \\
\hline 5 & 0.47 & 21 to 30 & 0.38 \\
\hline 6 & 0.45 & 21 to 37 & 0.37 \\
\hline 7 & 0.44 & 38 to 70 & 0.36 \\
\hline
\end{tabular}

\section{EXAMPLE LATERAL DESIGN:}

\section{Assume:}

Flow per dripper $=4 \mathrm{LPH}$

Dripper to dripper spacing $=0.5 \mathrm{~m}$

Lateral diameter $=12 \mathrm{~mm}$ (inside diameter $=10.7 \mathrm{~m}$ )

What should be maximum permissible length of lateral to have a head loss of $2 m=$ ?

Solution:

\begin{tabular}{|l|c|c|}
\hline Particulars & Unit & H.Zone1 \\
\hline Lateral Length & $\mathrm{m}$ & 29 \\
\hline Inside diameter & $\mathrm{mm}$ & 10.8 \\
\hline Pipe material & $\mathrm{m}$ & 150 \\
\hline Pipe friction coefficient & Nos. & 0.5 \\
\hline Emitter spacing & $\mathrm{LPH}$ & 58 \\
\hline No. of emitters & $\mathrm{LPH}$ & 4 \\
\hline Emitter flow rate & - & 232 \\
\hline Lateral flow rate & $\mathrm{m}$ & 0.36 \\
\hline Factor for multiple outlet & $\mathrm{m} / 100 \mathrm{~m}$ & 0 \\
\hline Fittings loss for emitters & $\mathrm{m} / 100 \mathrm{~m}$ & 2.9 \\
\hline Head loss (Watter \& Keller) & $\mathrm{m}$ & 2.4 \\
\hline Head loss (Hazzen Willam) & $\mathrm{m} / \mathrm{sec}$ & 0.84 \\
\hline Total lateral head loss, $\mathrm{h}_{\mathrm{f}}$ & & $\mathbf{0 . 7 0}$ \\
\hline Velocity & & \\
\hline
\end{tabular}




\begin{tabular}{|l|c|}
\hline Emitter operating pressure= & 10 \\
\hline Required lateral head loss $\mathbf{( 2 0} \%)=$ & 2 \\
\hline Calculated lateral head loss $=$ & 0.84 \\
\hline & OK \\
\hline
\end{tabular}

Lateral is Selected

\section{Step 13. Design of sub-main line}

On the manifolds, whether these pipelines are the sub-main or the mains as well, a number of laterals are fed simultaneously. The flow of the line is distributed en route, as in the laterals with the emitters. Consequently, when computing the friction losses.

The mains, sub-main and all hydrants are selected in such sizes that the friction losses do not exceed approximately 15 percent of the total dynamic head required at the beginning of the system's piped network. On level ground, these friction losses amount to about 20 percent of the emitter's fixed operating pressure. This is a practical rule for all pressurized systems to achieve uniform pressure conditions and water distribution at any point of the systems. The above figure should not be confused with or related in any way to the maximum permissible friction losses along the laterals.

\section{Criteria}

- Maximum Water Velocity in sub-main and mainline $=1.5 \mathrm{~m} / \mathrm{s}$

- Maximum Frictional Losses in sub-main $=2 \mathrm{~m}$

- Maximum Frictional Losses in mainline $=20 \mathrm{~m}$ per $1000 \mathrm{~m}$ length

- Hazen Williams Equation for Frictional Losses

Assume:

Flow per dripper $=4 \mathrm{LPH}$

Dripper to dripper spacing $=0.5 \mathrm{~m}$

Lateral to lateral spacing $=1.52 \mathrm{~m}$

Sub-main diameter $=3 \mathrm{inch}=75 \mathrm{~mm}$ (inside diameter $=71.2 \mathrm{~mm}$ )

What should be sub-main maximum permissible length to have a head loss of $2 \mathrm{~m}=$ ?

\begin{tabular}{|l|l|c|}
\hline Particulars & \multicolumn{1}{|c|}{ Unit } & H.Zone1 \\
\hline Sub-Mainline Length & $\mathrm{m}$ & 50 \\
\hline Inside diameter & $\mathrm{mm}$ & 71.2 \\
\hline Pipe material & \multicolumn{1}{|c|}{ PVC } \\
\hline Pipe friction coefficient & $\mathrm{m}$ & 150 \\
\hline Lateral spacing & $\mathrm{Nos}$. & \\
\hline No. of laterals operating & $\mathrm{LPH}$ & \\
\hline Lateral flow rate & $\mathrm{LPH}$ & 30000 \\
\hline Sub-mainline flow rate & - & 0.36 \\
\hline Factor for multiple outlet & $\mathrm{m} / 100 \mathrm{~m}$ & 1.84 \\
\hline Head loss gradient (Watter \& Keller) & $\mathrm{m} / 100 \mathrm{~m}$ & 1.97 \\
\hline Head loss gradient (Hazzen Willam) & $\mathrm{m}$ & 1.0 \\
\hline Total head loss, $\mathrm{h}_{\mathrm{f}}$ & $\mathrm{m} / \mathrm{s}$ & $\mathbf{2 . 0 9}$ \\
\hline Velocity & \multicolumn{2}{|l|}{} \\
\hline
\end{tabular}


Sub-main is selected

\section{STEP 14: Selection and Design of Mainline}

\section{CRITERIA:}

- Should be selected based on the quantity of water, length, elevation of ground, velocity, cost etc.

- Permissible velocity :

Less than $1.5 \mathrm{~m} / \mathrm{s}$

- Frictional losses:

Less than $2 \mathrm{~m} / 100 \mathrm{~m}$

- Economics:

- Elevation and Class of Pipe:

Less initial and annual operating cost

Pipe class affects the system cost, use appropriate pressure class pipe and try to lay the pipe at same elevation

- Control measures:

Pressure relief valves at appropriate location i.e., where elevation changes

\section{EXAMPLE}

Assume

Mainline length $=418 \mathrm{~m}$

Diameter $=6$ inch $=150 \mathrm{~mm}$ (inside diameter $=133 \mathrm{~mm}$ )

Designed discharge $=60700 \mathrm{lps}$

Material is PVC $(\mathrm{C}=150)$

Calculate friction loss and check velocity

\begin{tabular}{|l|l|c|}
\hline Particular & \multirow{2}{*}{ Unit } & Section \\
\cline { 3 - 3 } & & $\mathbf{1}$ \\
\hline Length & $\mathrm{m}$ & 418 \\
\hline Inside diameter & $\mathrm{mm}$ & 133 \\
\hline Pipe material & & PVC \\
\hline Pipe friction coefficient & & 150 \\
\hline Design capacity & $\mathrm{LPH}$ & $\mathbf{6 0 7 0 0}$ \\
\hline Head loss gradient (Watter \& Keller) & $\mathrm{m} / 100 \mathrm{~m}$ & $\mathbf{0 . 9 0}$ \\
\hline Head loss gradient (Hazzen Willam) & $\mathrm{m} / 100 \mathrm{~m}$ & $\mathbf{0 . 9 6}$ \\
\hline Mainline fittings losses & $\mathrm{m}$ & 0 \\
\hline Flow velocity & $\mathrm{m} / \mathrm{s}$ & $\mathbf{1 . 2 1}$ \\
\hline Total mainline head loss & $\mathrm{m}$ & $\mathbf{4 . 0 1}$ \\
\hline
\end{tabular}

\section{Main line is selected}

\subsection{Head Loss Through Fittings}

The three conventional methods for computing the additional pressure-head losses from special equipment, valves, pipe and fittings are: (1) graphing friction loss vs. flow rate, (2) expressing the added pressure head loss as the length of pipe (of the same diameter) that would give the same loss, and (3) expressing the loss in terms of a velocity head coefficient. Following Equation 5.5 can be used for computing friction head loss caused by a specific fitting (he), feet.

$$
\mathrm{h}_{\mathrm{e}}=\mathrm{K}_{\mathrm{f}} \frac{\mathrm{V}^{2}}{2 \mathrm{~g}}
$$


Where;

$\mathrm{Kf}=$ friction head-loss coefficient for a specific fitting.

$V^{2} / 2 g$ = velocity head, which is the energy head from the velocity of flow, feet or $m$.

Kf values should be supplied by manufacturers or taken from handbooks on hydraulics. Usually the losses attributed to standard pipe fittings are small and can be grouped in a miscellaneous friction-loss or safety factor.

\section{Step 15. Selection of Filters and their Head Loss}

There are four kinds of filters used in different combination depending upon source of water

- Hydrocylone Filter $(\mathrm{H})$

- Sand Media (S)

- Disc Filter (D)

- Screen filters

Application:

- $\mathrm{H}+\mathrm{S}+\mathrm{D}=$ When Water quality is very bad, contains silt particles

- $S+D=$ Open Well, Tank, Pond, Reservoir, Canal

- $\mathrm{H}+\mathrm{D}=$ Borewell

- $\quad \mathrm{D}$ (only) $=$ When water is very clean

To prevent solid particles in the water from penetrating the irrigation system and clogging the drippers

- Source of water

- Type, size and concentration of physical impurities

- Type of irrigation system

- Ease of handling, cleaning, maintenance and repairing

- Filtration media and frictional losses

- Economical investment, maintenance and power cost 


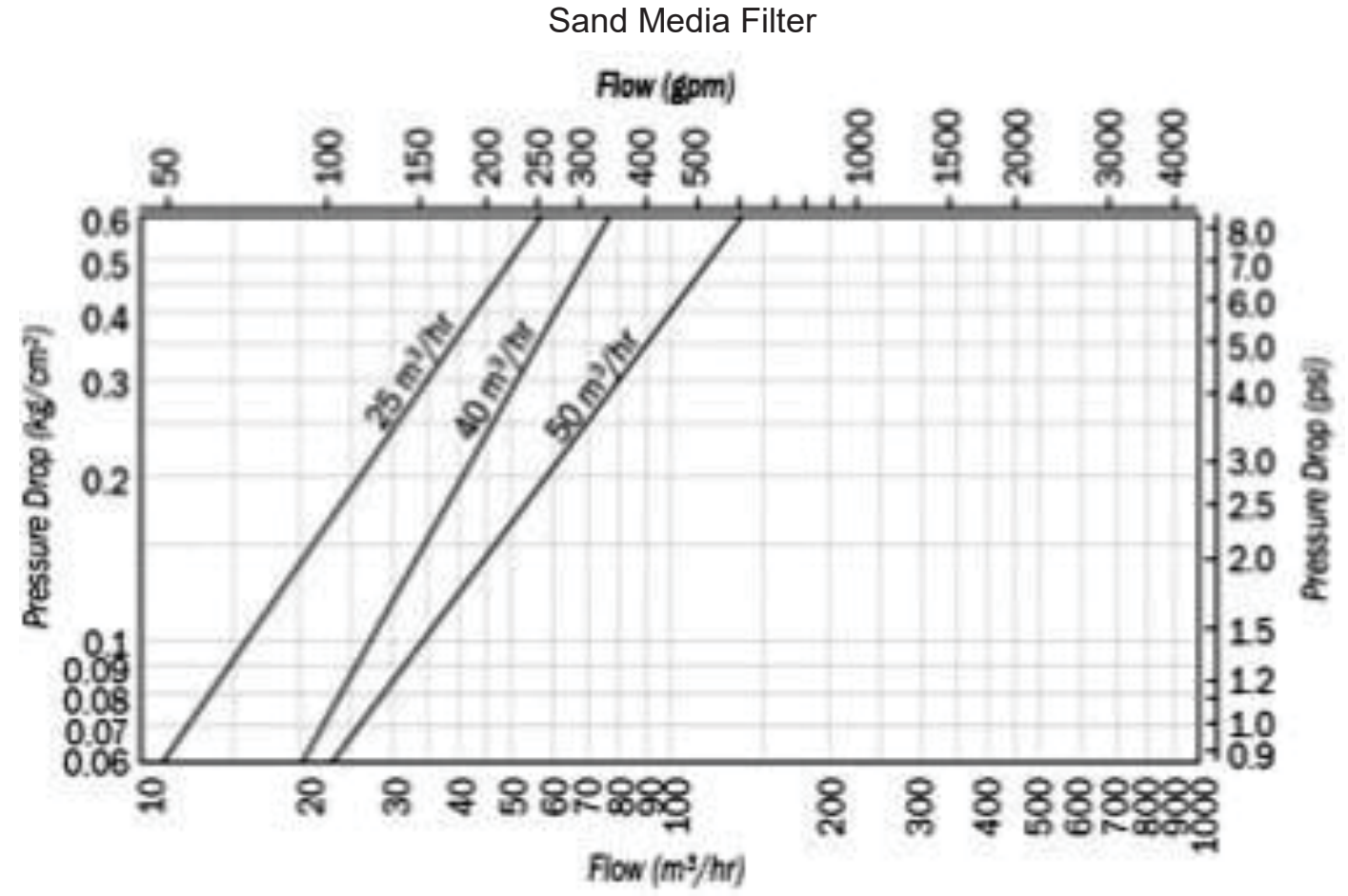

Hydrocyclone Filter

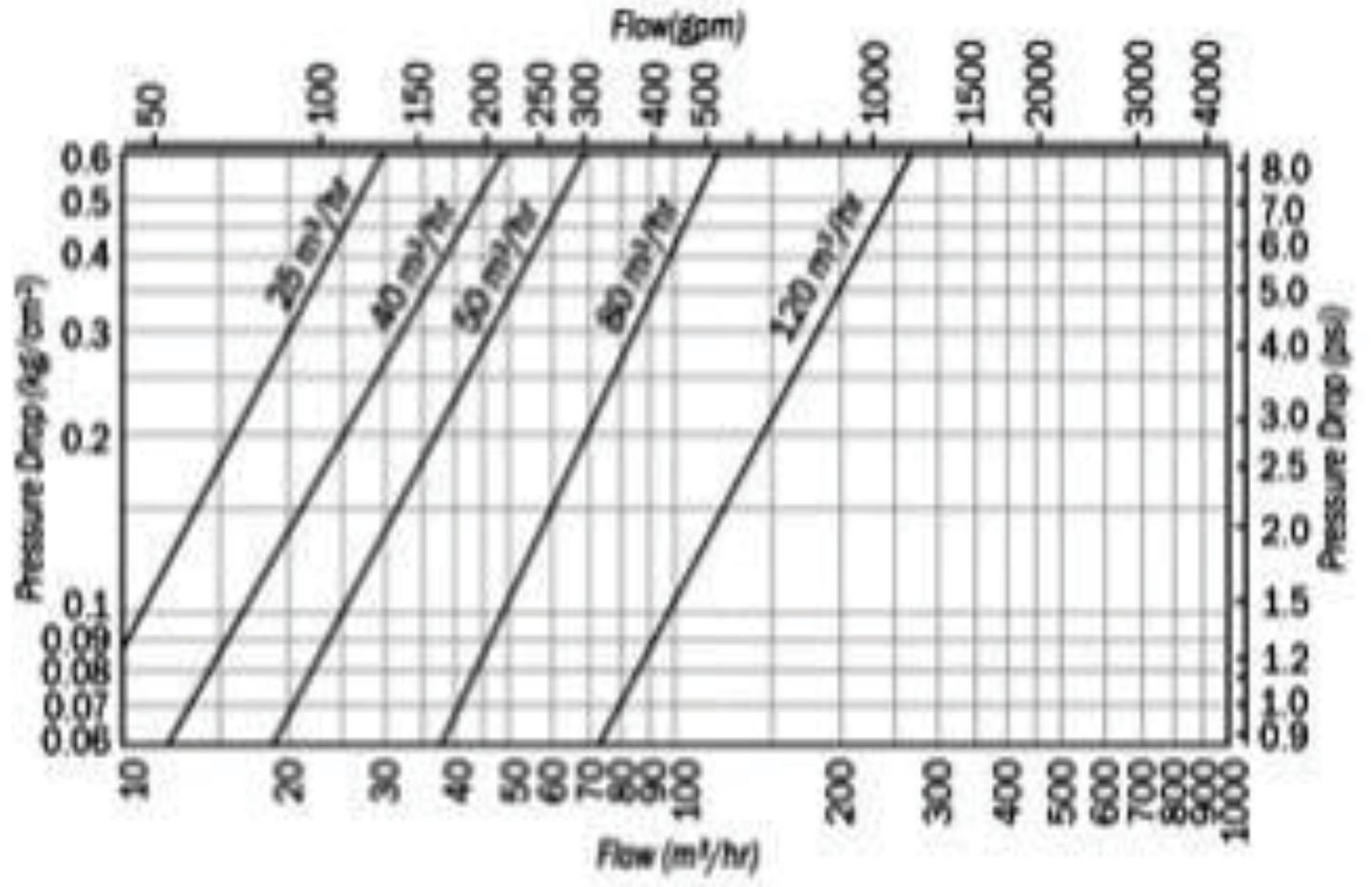




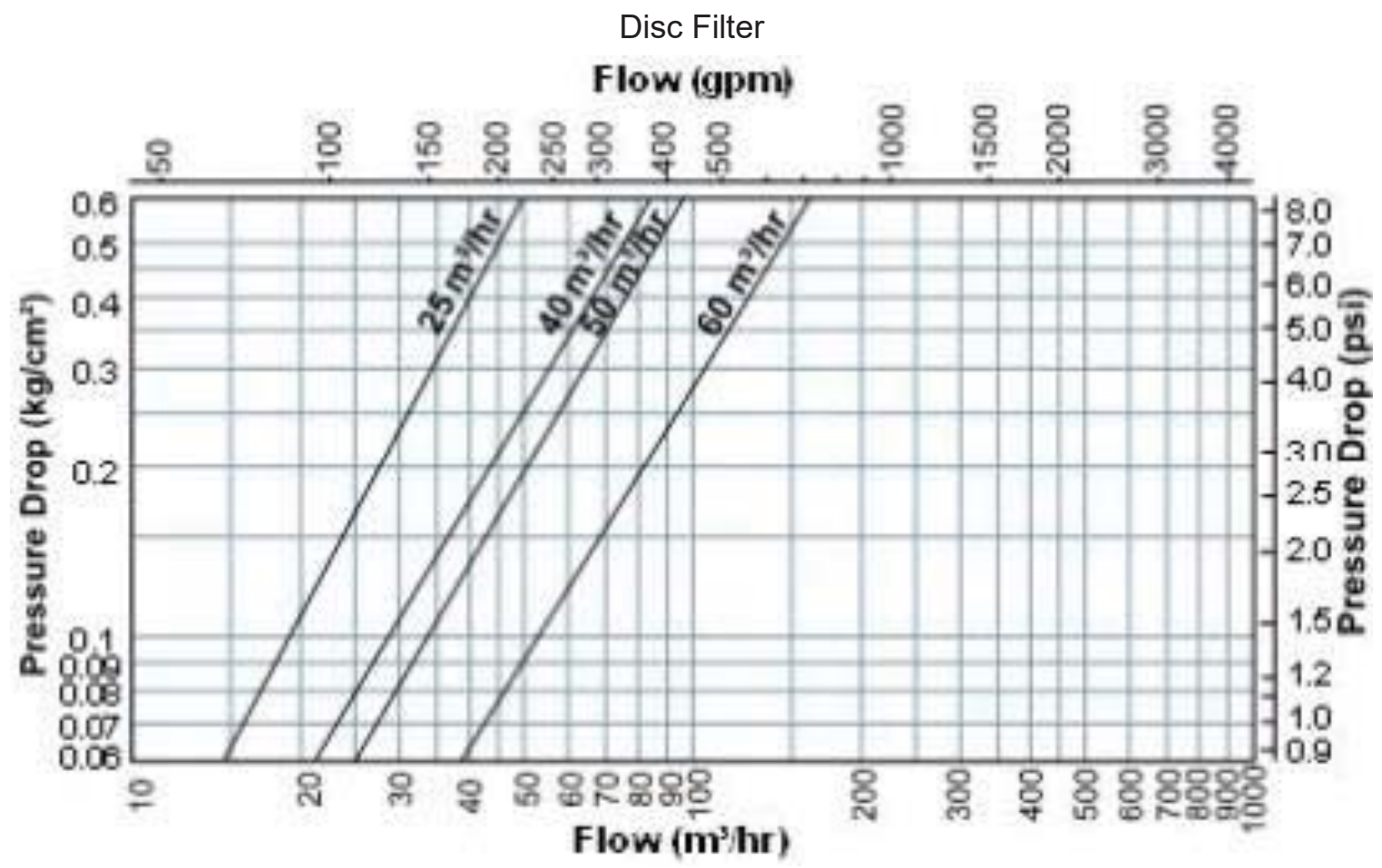

Selection of Valves

- The Valve can take upto $40 \%$ more flow than the pipe flow rate. Hence the Valve size can be one size less than the Pipeline Size

- The Friction loss in the Valve will be upto $2 \mathrm{~m}$ approx.

\subsection{TOTAL DYNAMIC HEAD}

Total Dynamic head is the total pressure required to provide the required pressure at the end of the last emitter. It is calculated as follows

Total Dynamic Head = $\quad=\quad$ suction head + delivery head + filter losses + mainline losses

+ sub-mainline losses + lateral loss + Fertigation system loss + fitting loss + - elevation difference + operating pressure

\begin{tabular}{|l|l|c|}
\hline Emitter operating pressure & $\mathrm{m}$ & 10 \\
\hline Elevation difference & $\mathrm{m}$ & 0 \\
\hline Total Head Loss (Pipe network) & $\mathrm{m}$ & 9 \\
\hline Fitting loss Lateral & $\mathrm{m}$ & 0.1 \\
\hline Fitting loss Mainline & $\mathrm{m}$ & 0.6 \\
\hline Fitting loss Sub-mainline & $\mathrm{m}$ & 0.6 \\
\hline Fitting loss Head unit & $\mathrm{m}$ & 0.7 \\
\hline Head loss in filters & $\mathrm{m}$ & 12 \\
\hline Head loss in fertigation system & $\mathrm{m}$ & 4 \\
\hline Head loss in flow meter & $\mathrm{m}$ & 1 \\
\hline Field fitting losses & $\mathrm{m}$ & 0 \\
\hline Miscellaneous head loss & $\mathrm{m}$ & 2 \\
\hline Pumping lift & $\mathrm{m}$ & 2 \\
\hline Total Dynamic Head & $\mathrm{m}$ & 42 \\
\hline
\end{tabular}


Total pipe network headloss/Total Dynamic Head $(\%)=$

Total pipe network HL $<25 \%$ of Total Dynamic Head

Lateral head loss may be less than $20 \%$ of the emitter operating pressure

Flow velocity less than $1.5 \mathrm{~m} / \mathrm{sec}$

Main line and submainline head loss may be less than $1 \mathrm{~m} / 100 \mathrm{~m}$

\section{Step 17. Calculation of Required Horse Power}

Pumps and lifting/propelling devices are often classified on the basis of the mechanical principle used to lift the water: direct lift, displacement, creating a velocity head, using the buoyancy of a gas or gravity. Most categories sub-divide into further classifications "reciprocating/cyclic" and "rotary". Virtually all water lifting devices can best be characterized for practical purposes by measuring their output at different heads and speeds. Normally the performance of a pump is presented on a graph of head versus flow (an H-Q graph) and in most cases curves can be defined for the relationship between $\mathrm{H}$ and $\mathrm{Q}$ at different speeds of operation. Invariably there is a certain head, flow and speed of operation that represents the optimum efficiency of the device, i.e. where the output is maximized in relation to the power input. Some devices and pumps are more sensitive to variations in these factors than others; i.e. some only function well close to a certain design condition of speed, flow and head, while others can tolerate a wide range of operating conditions with little loss of efficiency.

- Selection of Pump and Motor depends on Flow and pressure required for system.

- Pressure is calculated after adding all the losses of the system and pressure required at emitters.

- An approximate HP for motor is calculated as follows:

$\bullet$

$$
H P=\frac{Q \times H}{75 \times E 1 \times E 2}
$$

where:

$Q$ is discharge, LPS

$\mathrm{H}$ is the total head, $\mathrm{m}$;

$\mathrm{E} 1$ is the pump efficiency (fraction in the order of 0.5-0.8); and

$\mathrm{E} 2$ is the driving efficiency (fraction of 0.7-0.9 for electric motors and $0.5-0.75$ for diesel engines).

The overall pumping efficiency under field conditions ranges accordingly from 0.35 in engine driven units to 0.50 in motor driven pumps. Higher efficiencies are not realistic.

(Always rely on manufacturer chart to know the actual horse power)

\section{VIII) Pump \& Motor Requirement}

\begin{tabular}{|l|l|r|}
\hline PUMP REQUIREMENT & Unit & \\
\cline { 2 - 3 } Capacity & $(\mathrm{LPH})$ & $\mathbf{6 0 8 4 0}$ \\
\hline Head & $(\mathrm{m})$ & 42.0 \\
\hline Motor effciency & $(\%)$ & 0.5 \\
\hline Pump Efficiency (\%) & $(\%)$ & 0.6 \\
\hline Pump H.P required & H.P & 32 \\
\hline
\end{tabular}

Project - Implementation Supervision Consultants (PSC) 


\section{Step 18. Selection of Pump and Motor}

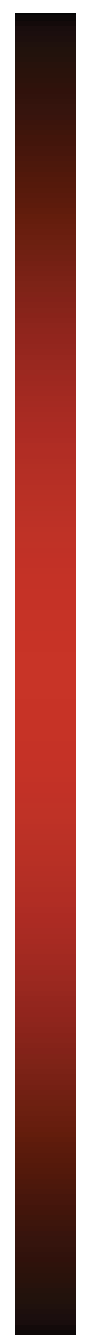

Curves for pump selection KSB - ETA 65-200
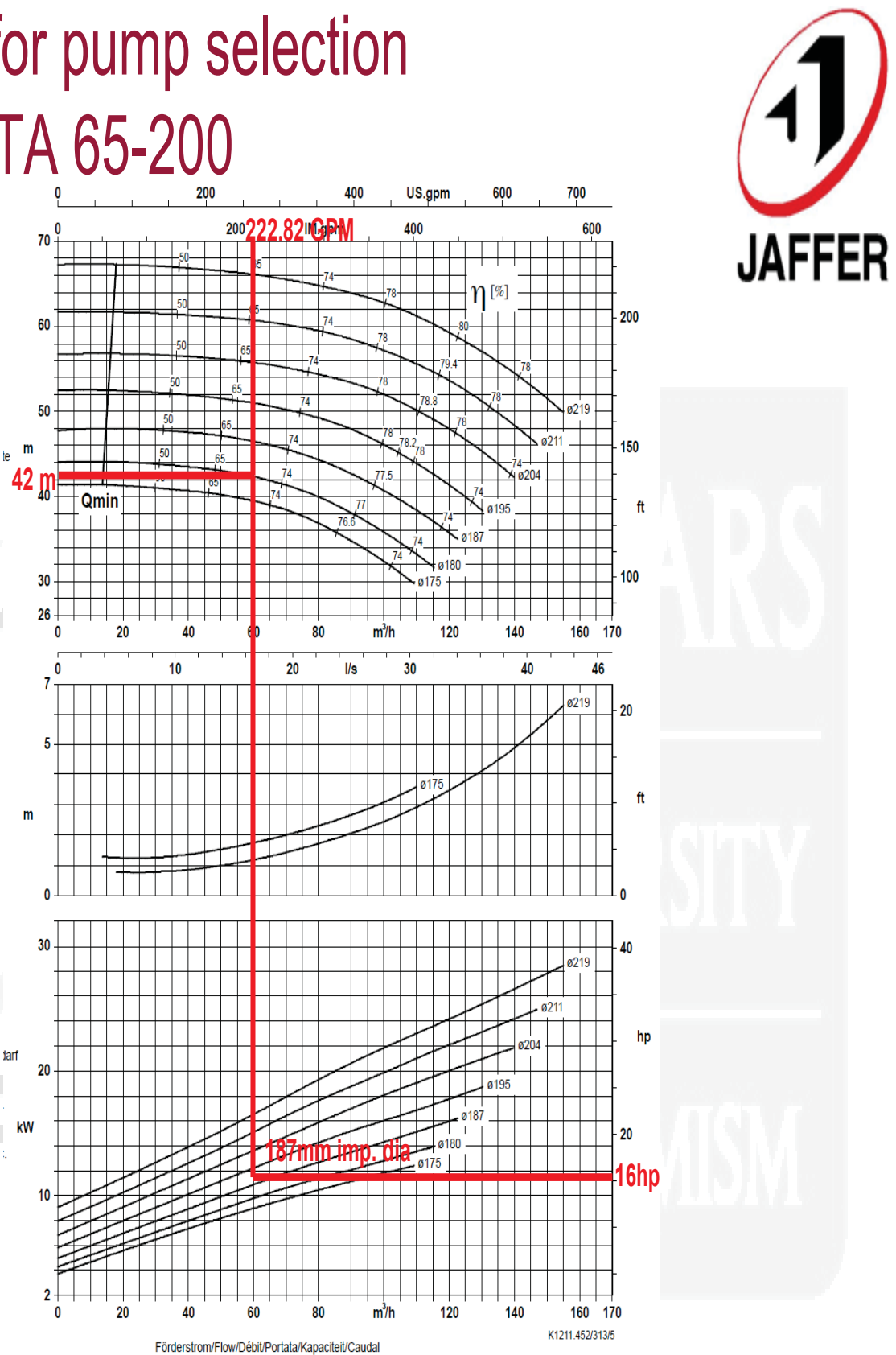

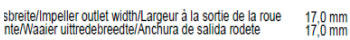




\section{Step 19. Preparation of drawing}

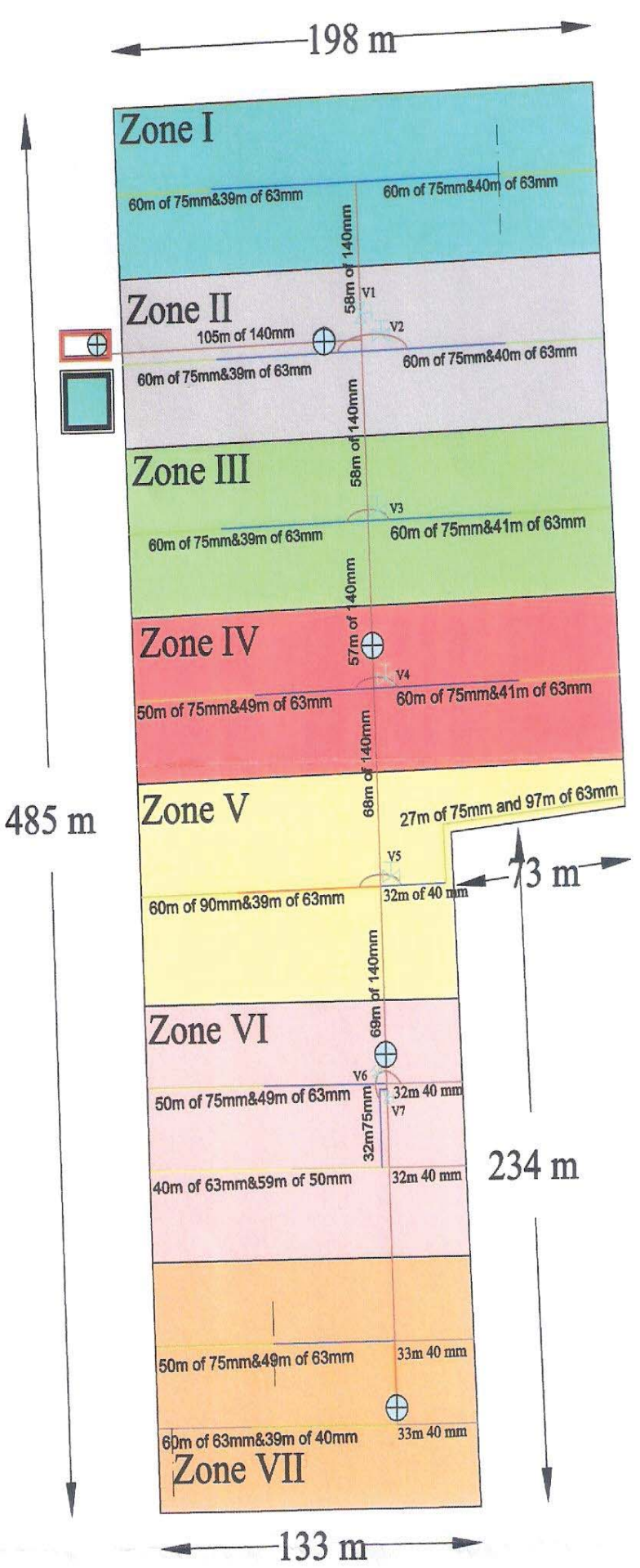

Zone \# 1 to 7

$12 \mathrm{~mm}$ lateral;Spacing $5 \mathrm{ft}$ 4lph, $50 \mathrm{~cm}$ emitter spacing Crop: Cotton

Area: 20Acre

Flow: $16.861 \mathrm{ps}$

Irrigation Time: $1 \mathrm{hrs} 45 \mathrm{~min}$
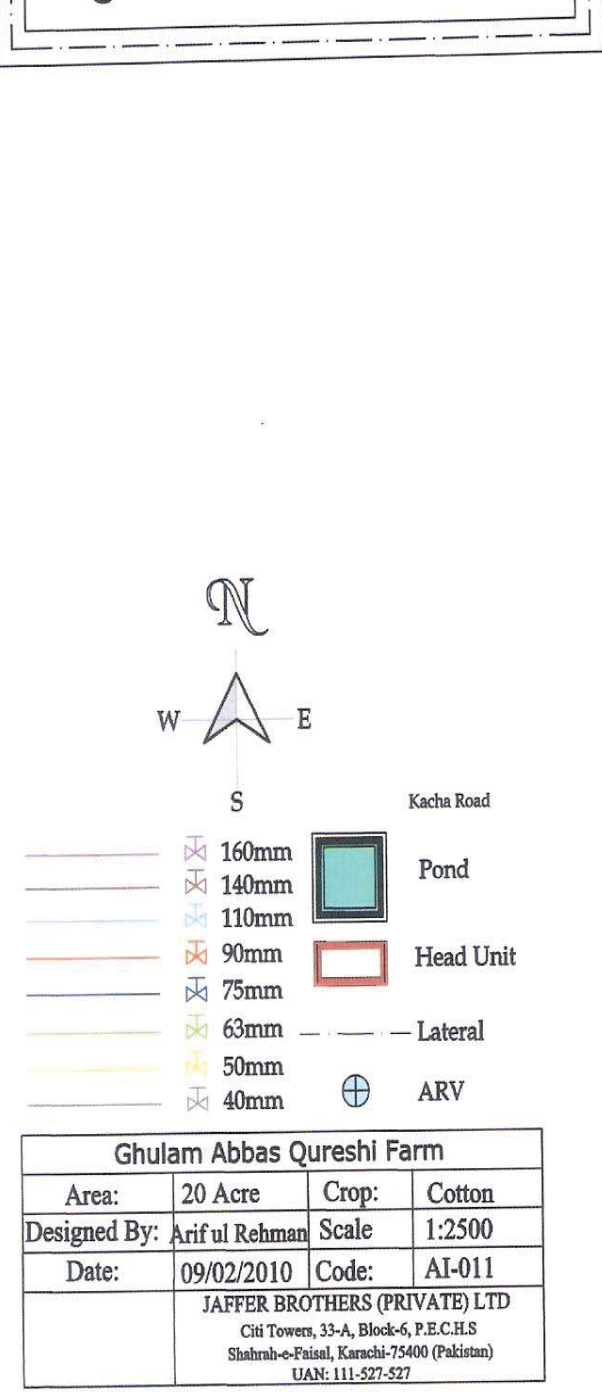


\section{Step 20. Preparation of bill of quantities BOQ}

Bill of Quantities is divided into following subsets:

- Pump Set, Head Unit, Valves, PVC Pipes and Fittings, Emitting System

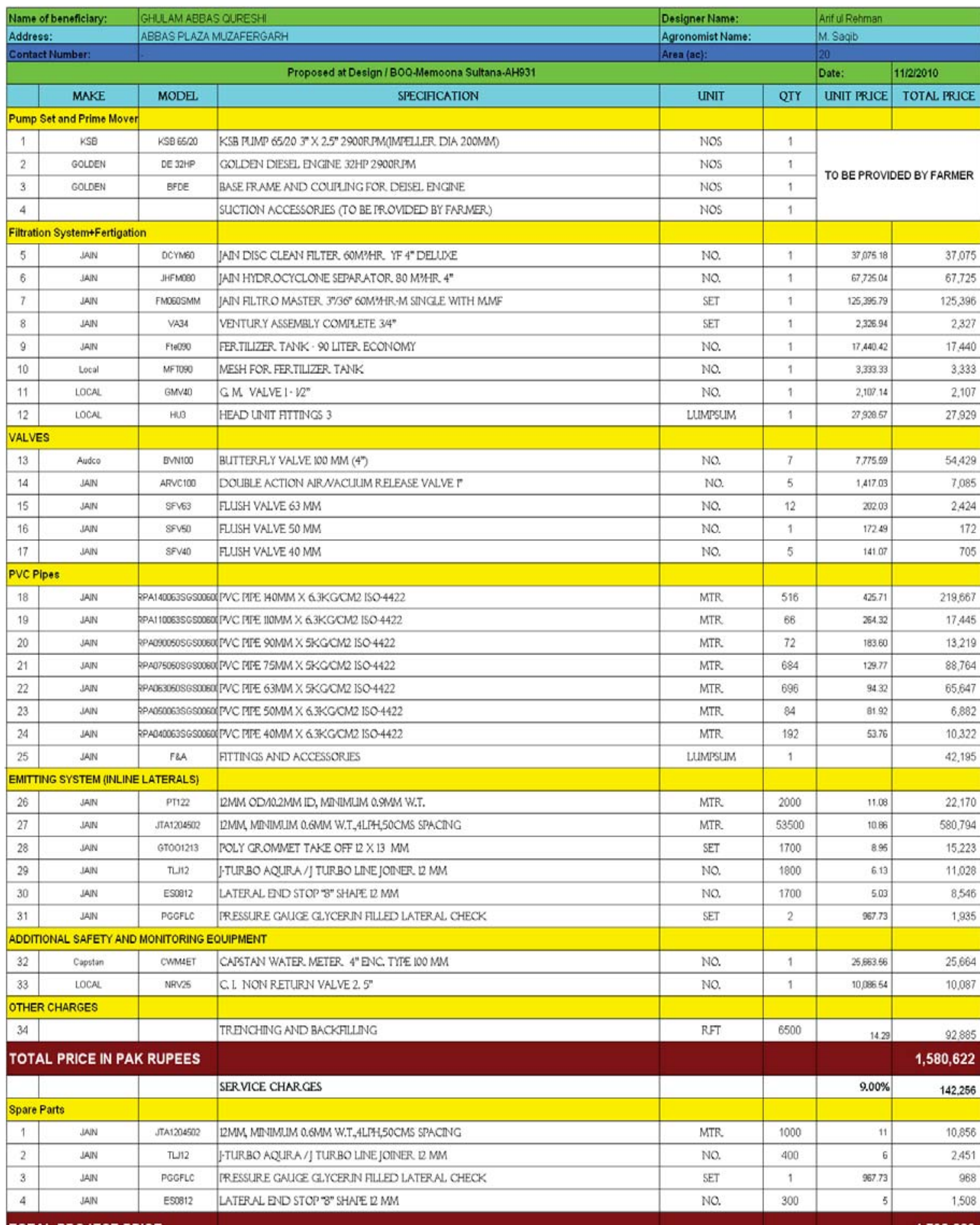

TOTAL PROJECT PRICE

Note:

The above quotation does not include cost of construction of PondiBore well and pumpset with prime mover along with the suction accessories. This will be provided by beneficiary as per specification provided by SSC.

- Safety and Monitoring Equipments 


\subsection{DESIGN OF DRIP IRRIGATION SYSTEM (ROW CROP)}

To design a drip irrigation system for 6.5 acres of cotton crop in Bhakkar. Soil is sandy loam. System should be farmer friendly.

Canal water is available for 2 hours and discharge is 28 lps. Farmer is interested to use canal water only but he can manage, ground water also.

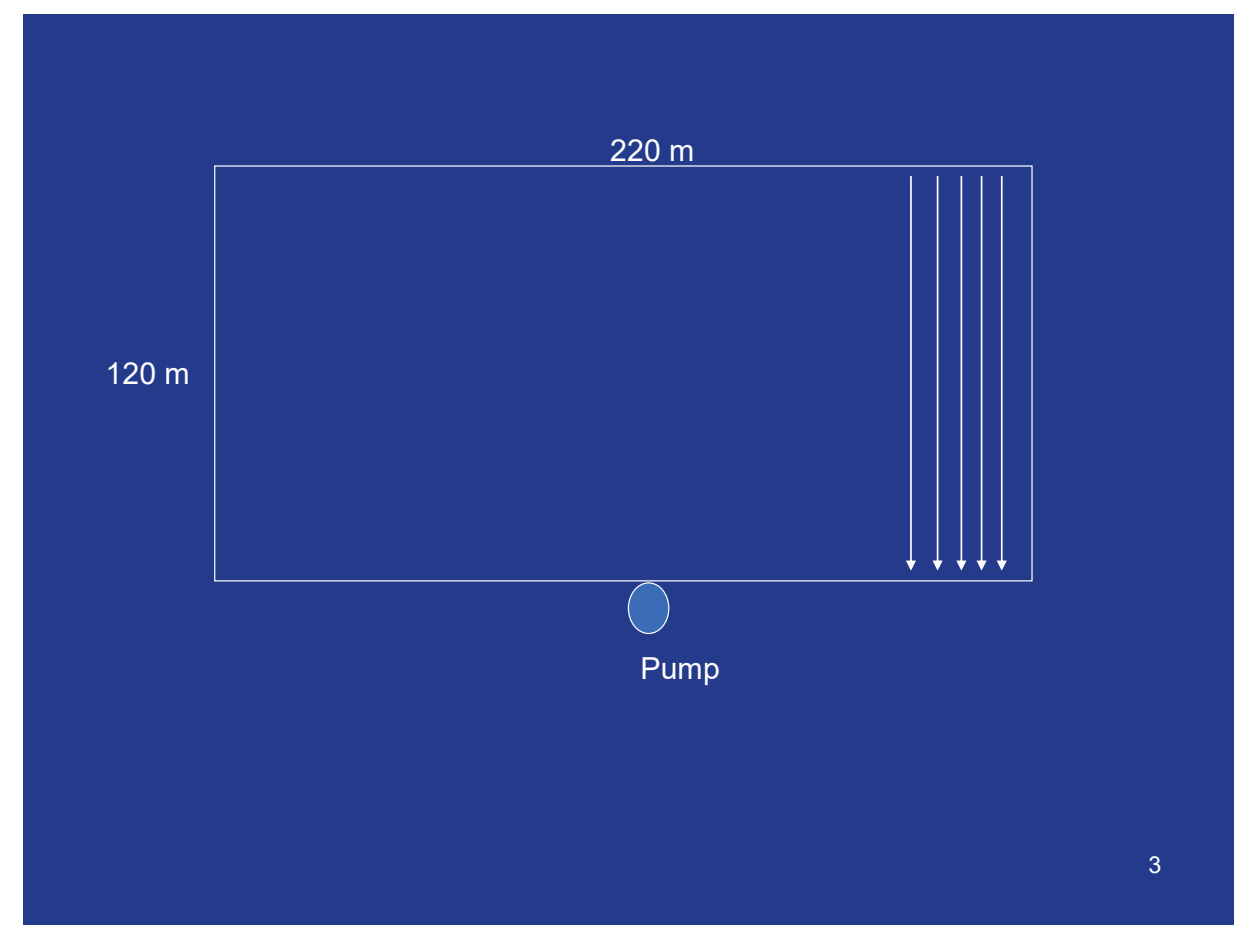

\section{Crop Information}

\begin{tabular}{|c|c|c|c|c|c|c|c|c|c|}
\hline & Parameters & & Crop & $\begin{array}{c}\text { Area } \\
\text { (acres) }\end{array}$ & $\begin{array}{l}\text { Plant } \\
\text { spacing }\end{array}$ & $\begin{array}{l}\text { Row } \\
\text { spacing }\end{array}$ & $\begin{array}{l}\text { Age of } \\
\text { crop }\end{array}$ & $\begin{array}{c}\text { Sowing } \\
\text { Date }\end{array}$ & $\begin{array}{c}\text { Harvestin } \\
\text { g Date }\end{array}$ \\
\hline & & Proposed & Cotton & 6.5 & 0.3 & 1.52 & new & 15 May & $15 \mathrm{Nov}$ \\
\hline & Kow crops & Rotation & & & & & & & \\
\hline & Sub-Total: & & & & & & & & \\
\hline D1 U & $0=1$ & Type-I & & & & & & & \\
\hline DIOCK-11 & Orcharcis & Type-II & & & & & & & \\
\hline & Sub-Total: I & & & & & & & & \\
\hline Block-III & Annua & rops & & & & & & & \\
\hline & Sub-Total: I & & & & & & & & \\
\hline D1 IV & $\Gamma \cdot 10$ & Type-I & & & & & & & \\
\hline DIOCK-IV & Fiera Crops & Type-II & & & & & & & \\
\hline & Sub-Total: I & & & & & & & & \\
\hline & tal / Design V & & & 6.5 & 0.3 & 1.52 & & 15 May & $15 \mathrm{Nov}$ \\
\hline
\end{tabular}




\section{EVAPOTRANSPIRATION AND CROP COEFFICIENTS (ETO \& KC)}

\begin{tabular}{|l|l|l|l|l|l|l|l|l|l|l|l|l|}
\hline Month & J & F & M & A & M & J & J & A & S & O & N & D \\
\hline Eto (mm/d) & 1.8 & 2.7 & 4.0 & 6.4 & 8.6 & 9.2 & 7.6 & 6.5 & 5.8 & 4.5 & 2.7 & 1.9 \\
\hline Kc (row crop) & & & & & 0.4 & 0.6 & 0.8 & 1.2 & 1.1 & 0.4 & 0.4 & \\
\hline CWR (row crop) & & & & & 3.4 & 5.5 & 6.1 & 7.8 & 6.4 & 2.1 & 1.1 & \\
\hline Kc (orchards) & & & & & & & & & & & & \\
\hline CWR (orchards) & & & & & & & & & & & & \\
\hline Kc (annual crop) & & & & & & & & & & & & \\
\hline CWR (annual crop) & & & & & & & & & & & & \\
\hline Kc (field crops) & & & & & & & & & & & & \\
\hline CWR (field crops) & & & & & & & & & & & & \\
\hline
\end{tabular}

\section{Water Sources}

\begin{tabular}{|c|c|c|}
\hline \multicolumn{2}{|l|}{ Soil type } & Loamy Sand \\
\hline \multicolumn{2}{|l|}{ Water Sources } & \\
\hline \multicolumn{2}{|l|}{ 1) Canal } & \\
\hline \multicolumn{2}{|c|}{ Sanctioned Discharge (LPS) } & 28 \\
\hline \multicolumn{2}{|c|}{ Perennial / Non Perennial } & Non-Perennial \\
\hline \multicolumn{2}{|l|}{ Warabandi (Days) } & 7 \\
\hline \multirow[t]{2}{*}{ Water Availability } & Hrs/Warabandi & 2 \\
\hline & Volume (m3) & \\
\hline
\end{tabular}




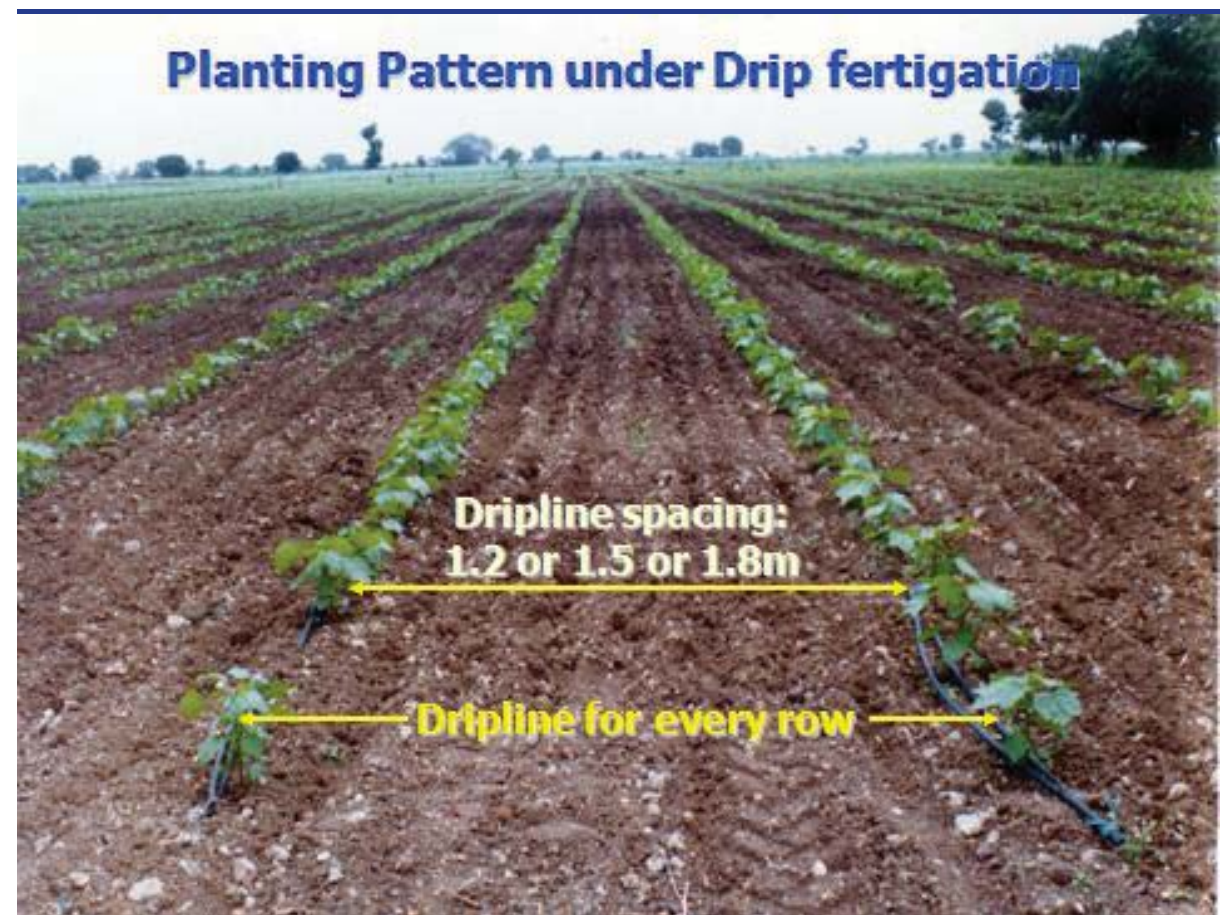

\begin{tabular}{|r|l|l|l|}
\hline \multicolumn{5}{|l|}{} & Total area under HEIS & Acres & 6.5 \\
\hline 2. & Design reference evapotranspiration, ETo & $\mathrm{mm} /$ day & 6.5 \\
\hline 3. & Design Crop factor at maturity, Kc & - & 1.2 \\
\hline 4. & Plant spacing & $\mathrm{m}$ & 0.3 \\
\hline 5. & Lateral spacing & $\mathrm{m}$ & 1.52 \\
\hline 6. & Shaded area & $\%$ & 100 \\
\hline 7. & Irrigation system efficiency & $\%$ & 90 \\
\hline 8. & Emitter flow rate & LPH & 2 \\
\hline 9. & Emitter spacing & $\mathrm{m}$ & 0.4 \\
\hline 10. & No. of crop rows per drip line & Nos. & 1.0 \\
\hline 11. & Irrigation cycle (assume one day) & Days & 1 \\
\hline
\end{tabular}




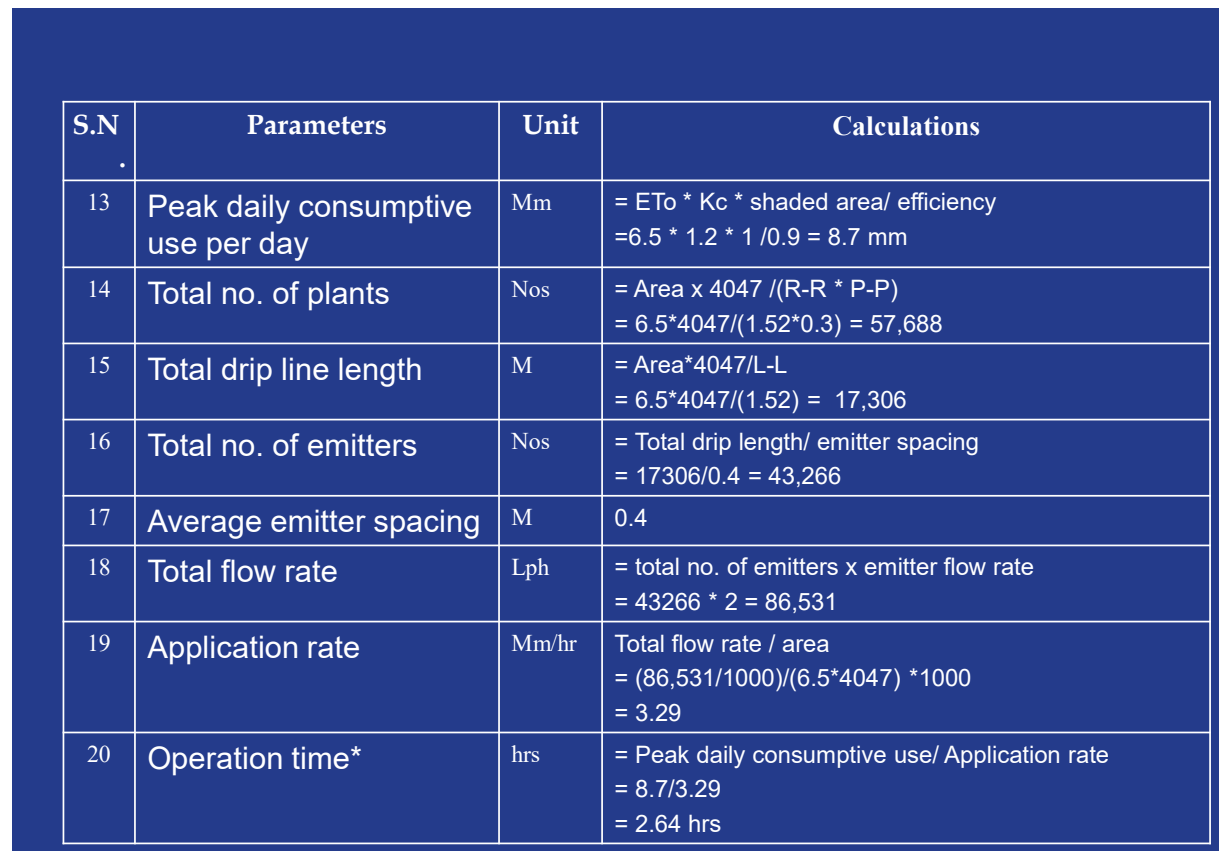

\section{Do We Have Sufficient Water?}

Peak Water Requirement $=8.7 \mathrm{~mm} /$ day (calculated previously)

Volume of water required $(\mathrm{m} 3 / \mathrm{d})$

$$
\begin{aligned}
& =P W R \times \text { Area }(\mathrm{m} 2) \\
& =8.7 / 1000^{*} 6.5^{*} 4047 \\
& =229 \text { cubic meters per day }
\end{aligned}
$$

Water Availability

a) For Canal Water

Outlet discharge $\quad=28 \mathrm{lps}$

Warabandi period $=2 \mathrm{hrs}$

Total water availability $=28 / 1000 * 3600 * 2=202$ cubic meters for seven days

NO

Water is not sufficient to design a drip irrigation system for 6.5 acres.

Options:

a) Reduce area

Or

b) Arrange alternate water source

Go for option b) as farmer has arranged water source i.e., tubewell water:

Proceed further 


\section{Option-I (Irrigate entire area at a time)}

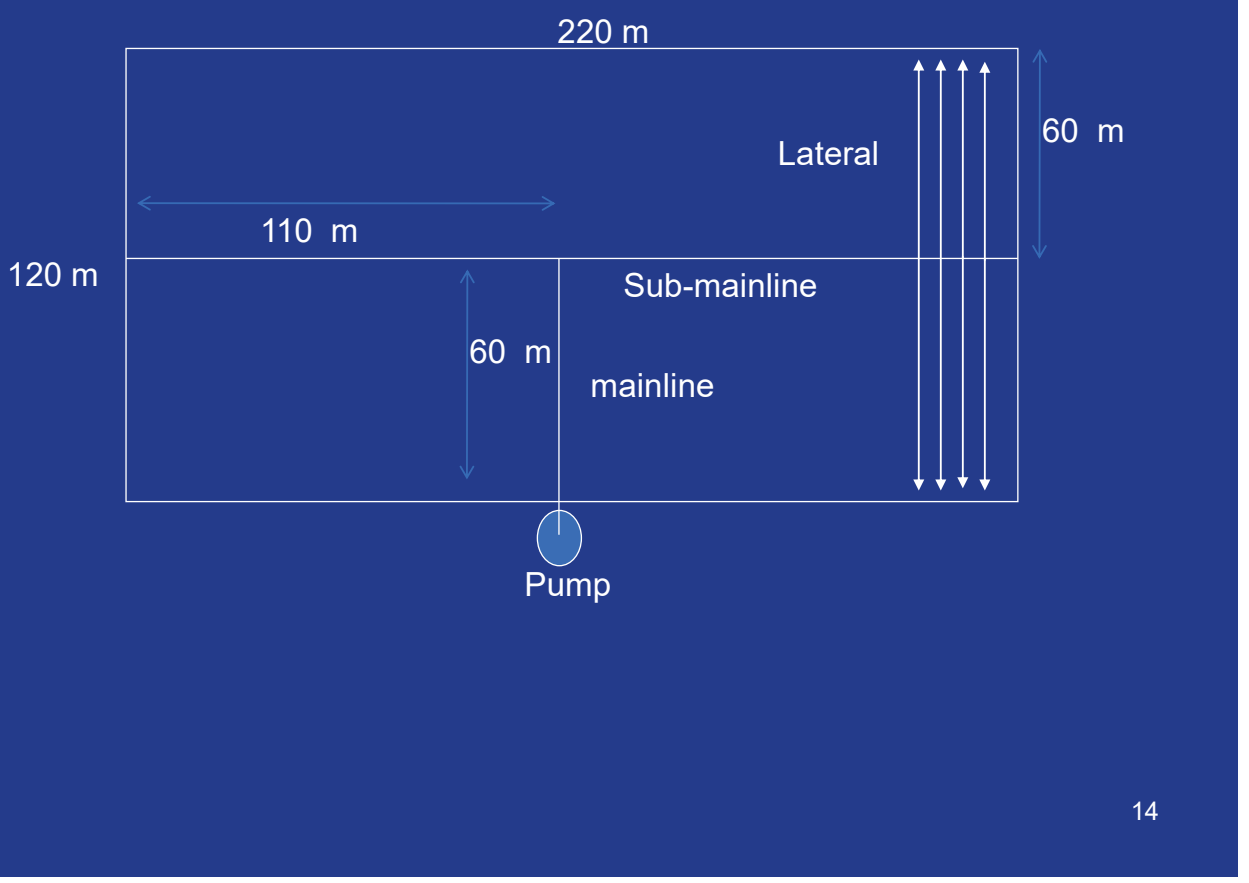

Darcy- Weisbach and Blasius Equation can be combined to give accurate prediction of friction head loss for smooth plastic pipes of less than $125 \mathrm{~mm}$ (5 in.) diameter.

$$
\begin{array}{ll}
\mathbf{J}=100 \mathbf{h f} / \mathbf{L}=\mathbf{k}^{*}\left[\left(\mathbf{Q}^{1.75}\right) /\left(\mathbf{D}^{4.75}\right)\right] \\
\mathrm{J} & =\text { Head loss gradient, } \mathrm{m} / 100 \mathrm{~m} \\
\mathrm{Hf} & =\text { pipe friction head loss, } \mathrm{m} \\
\mathrm{K} & =\text { Constant, } 7.89 * 10^{\wedge} 7 \text { for metric units } \\
\mathrm{Q} & =\text { Flow Rate, LPS } \\
\mathrm{L} & =\text { Pipe length, } \mathrm{m} \\
\mathrm{D} & =\text { Inside Diameter of Pipe, } \mathrm{mm}
\end{array}
$$

Darcy- Weisbach and Blasius Equation can be combined to give accurate prediction of friction head loss for smooth plastic pipes of less than $125 \mathrm{~mm}(5 \mathrm{in}$.) diameter.

$$
\begin{array}{ll}
\mathbf{J}=100 & \mathbf{h f} / \mathbf{L}=\mathbf{k}^{*}\left[\left(\mathbf{Q}^{\wedge} \mathbf{1 . 7 5}\right) /\left(\mathbf{D}^{\wedge} \mathbf{4 . 7 5}\right)\right]{ }^{*} \mathbf{F} \\
\mathrm{J} & =\text { Head loss gradient, } \mathrm{m} / 100 \mathrm{~m} \\
\mathrm{Hf} & =\text { pipe friction head loss, } \mathrm{m} \\
\mathrm{K} & =\text { Constant, } 7.89 * 10^{\wedge} 7 \mathrm{for} \quad \text { metric units } \\
\mathrm{Q} & =\text { Flow Rate, LPS } \\
\mathrm{L} & =\text { Pipe length, } \mathrm{m} \\
\mathrm{D} & =\text { Inside Diameter of Pipe, } \mathrm{mm}
\end{array}
$$


Lateral Design:

Lateral length $=60 \mathrm{~m}$

No. of emitters $=60 / 0.4=150$

Lateral flow rate $=300 \mathrm{lph}$

Assume $13 \mathrm{~mm}$ lateral line

Inside diameter $=10 \mathrm{~mm}$

$\left.J=7.89^{*} 10^{\wedge} 7^{*}\left[(300 / 3600)^{\wedge} 1.75\right) /\left(10^{\wedge} 4.75\right)\right] * 0.36$

$\mathrm{J}=6.53 \mathrm{~m} / 100 \mathrm{~m}$

For $60 \mathrm{~m}$ length

$\mathrm{Hf}=3.92 \mathrm{~m}$

Lateral Design:

Lateral length $=60 \mathrm{~m}$

No. of emitters $=60 / 0.4=150$

Lateral flow rate $=300 \mathrm{lph}$

Assume $16 \mathrm{~mm}$ lateral line

Inside diameter $=13 \mathrm{~mm}$

$\left.J=7.89^{*} 10^{\wedge} 7^{*}\left[(300 / 3600)^{\wedge} 1.75\right) /\left(13^{\wedge} 4.75\right)\right]^{*} 0.36$

$\mathrm{J}=1.9 \mathrm{~m} / 100 \mathrm{~m}$

For $60 \mathrm{~m}$ length

$\mathrm{Hf}=1.1 \mathrm{~m}$

Sub-Mainline Design:

Length $=120 \mathrm{~m}$

No. of laterals $=120 / 1.52=79$

Sub-main flow rate $=86531 / 2$

$=43265 \mathrm{lph}$

Assume $70 \mathrm{~mm}$ lateral line

Inside diameter $=63 \mathrm{~mm}$

$\left.J=7.89^{*} 10^{\wedge} 7^{*}\left[(43265 / 3600)^{\wedge} 1.75\right) /\left(63^{\wedge} 4.75\right)\right]^{*} 0.36$

$\mathrm{J}=6.3 \mathrm{~m} / 100 \mathrm{~m}$

For $120 \mathrm{~m}$ length

$\mathrm{Hf}=7.5 \mathrm{~m}$

Sub-Mainline Design:

Length $=120 \mathrm{~m}$

No. of laterals $=120 / 1.52=79$

Sub-main flow rate $=86531 / 2$

$=43265 \mathrm{lph}$ 
Assume $110 \mathrm{~mm}$ Sub-Mainline

Inside diameter $=104 \mathrm{~mm}$

$\left.J=7.89^{*} 10^{\wedge} 7^{*}\left[(43265 / 3600)^{\wedge} 1.75\right) /\left(104^{\wedge} 4.75\right)\right]^{*} 0.36$

$\mathrm{J}=0.6 \mathrm{~m} / 100 \mathrm{~m}$

For $120 \mathrm{~m}$ length

$\mathrm{Hf}=0.7 \mathrm{~m}$

Darcy- Weisbach and Blasius Equation can be combined to give accurate prediction of friction head loss for smooth plastic pipes of less than $125 \mathrm{~mm}$ (5 in.) diameter.

$$
\begin{array}{ll}
\mathbf{J}=\mathbf{1 0 0} \mathbf{h f} / \mathbf{L}=\mathbf{k}^{*}\left[\left(\mathbf{Q}^{\wedge} \mathbf{1 . 7 5}\right) /\left(\mathbf{D}^{\wedge} \mathbf{4 . 7 5}\right)\right] \\
\mathrm{J} & =\text { Head loss gradient, } \mathrm{m} / 100 \mathrm{~m} \\
\mathrm{Hf} & =\text { pipe friction head loss, } \mathrm{m} \\
\mathrm{K} & =\text { Constant, } 7.89^{*} 10^{\wedge} 7 \mathrm{for} \quad \text { metric units } \\
\mathrm{Q} & =\text { Flow Rate, } \mathrm{LPS} \\
\mathrm{L} & =\text { Pipe length, } \mathrm{m} \\
\mathrm{D} & =\text { Inside Diameter of Pipe, } \mathrm{mm}
\end{array}
$$

Mainline Design:

Length $=60 \mathrm{~m}$

Sub-main flow rate $=86531 \mathrm{LPH}$

Assume $110 \mathrm{~mm}$ Sub-Mainline

Inside diameter $=104 \mathrm{~mm}$

$\left.J=7.89^{*} 10^{\wedge} 7^{*}\left[(86531 / 3600)^{\wedge} 1.75\right) /\left(104^{\wedge} 4.75\right)\right]$

$\mathrm{J}=5.4 \mathrm{~m} / 100 \mathrm{~m}$

For $60 \mathrm{~m}$ length

$\mathrm{Hf}=3.2 \mathrm{~m}$

$V=1.274 q / d^{2}$

Where

$V=\operatorname{velocity}(\mathrm{m} / \mathrm{s})$

$Q=$ volume flow $\left(\mathrm{m}^{3} / \mathrm{s}\right)$

$D=$ pipe inside diameter $(m)$

$V=1.274 \times\left[(86531 /(1000 * 3600)] /\left[(104 / 1000)^{\wedge} 2\right]\right.$

$$
=3.68 \mathrm{~m} / \mathrm{s}
$$

Darcy- Weisbach and Blasius Equation can be combined to give accurate prediction of friction head loss for smooth plastic pipes of less than $125 \mathrm{~mm}$ (5 in.) diameter. 


$$
\begin{array}{ll}
\mathbf{J}=\mathbf{1 0 0} & \mathbf{h f} / \mathbf{L}=\mathbf{k}^{*}\left[\left(\mathbf{Q}^{\wedge} \mathbf{1 . 7 5}\right) /\left(\mathbf{D}^{\wedge} \mathbf{4 . 7 5}\right)\right] \\
\mathrm{J} & =\text { Head loss gradient, } \mathrm{m} / 100 \mathrm{~m} \\
\mathrm{Hf} & =\text { pipe friction head loss, } \mathrm{m} \\
\mathrm{K} & =\text { Constant, } 7.89^{*} 10^{\wedge} 7 \mathrm{for} \quad \text { metric units } \\
\mathrm{Q} & =\text { Flow Rate, } \mathrm{LPS} \\
\mathrm{L} & =\text { Pipe length, } \mathrm{m} \\
\mathrm{D} & =\text { Inside Diameter of Pipe, } \mathrm{mm}
\end{array}
$$

Mainline Design:

Length $=60 \mathrm{~m}$

Sub-main flow rate $=86531 \mathrm{LPH}$

Assume 170 mm Sub-Mainline

Inside diameter $=160 \mathrm{~mm}$

$\left.J=7.89^{*} 10^{\wedge} 7^{*}\left[(86531 / 3600)^{\wedge} 1.75\right) /\left(160^{\wedge} 4.75\right)\right]$

$\mathrm{J}=0.7 \mathrm{~m} / 100 \mathrm{~m}$

For $60 \mathrm{~m}$ length

$\mathrm{Hf}=0.4 \mathrm{~m}$

\section{Velocity of Mainline}

$v=1.274 q / d^{2}$

where

$v=$ velocity $(\mathrm{m} / \mathrm{s})$

$q=$ volume flow $\left(\mathrm{m}^{3} / \mathrm{s}\right)$

$d=$ pipe inside diameter $(m)$

$V=1.274 \times\left[(86531 /(1000 * 3600)] /\left[(104 / 1000)^{\wedge} 2\right]\right.$

$=1.20 \mathrm{~m} / \mathrm{s}$ 


\section{Velocity Formula to Determine Pipe Size for Mainline}

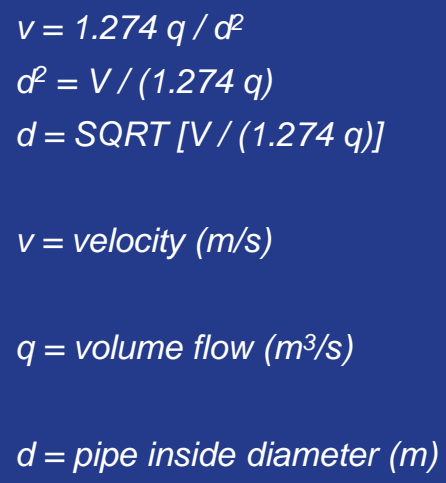

\section{Filters: Head Loss}

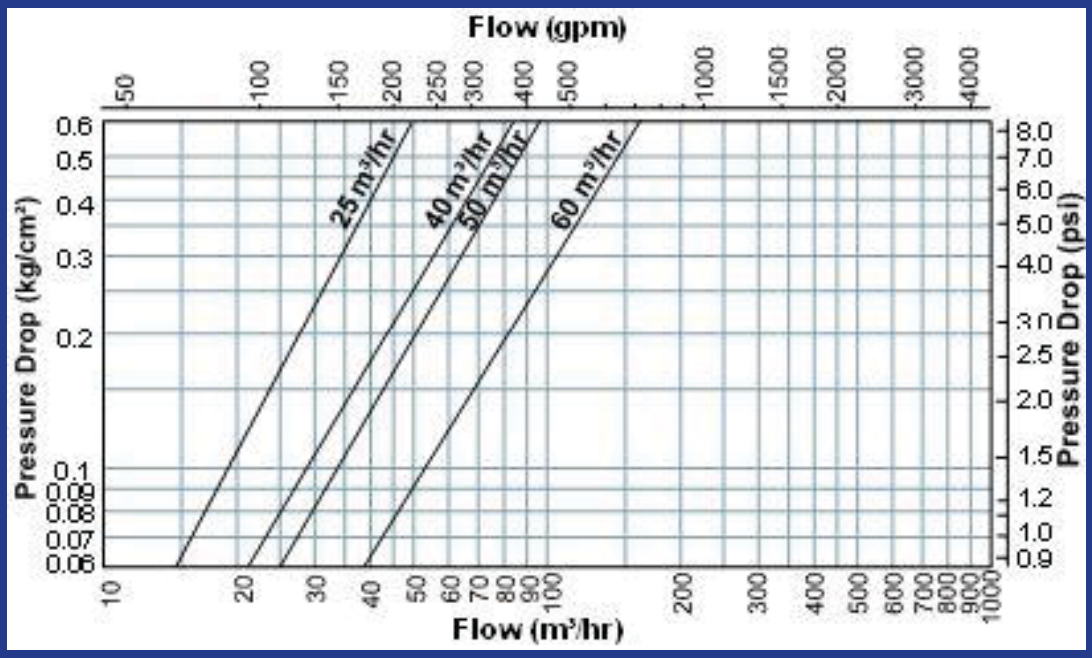

Source: Jain Disc Filter 


\section{Filters: Head Loss}

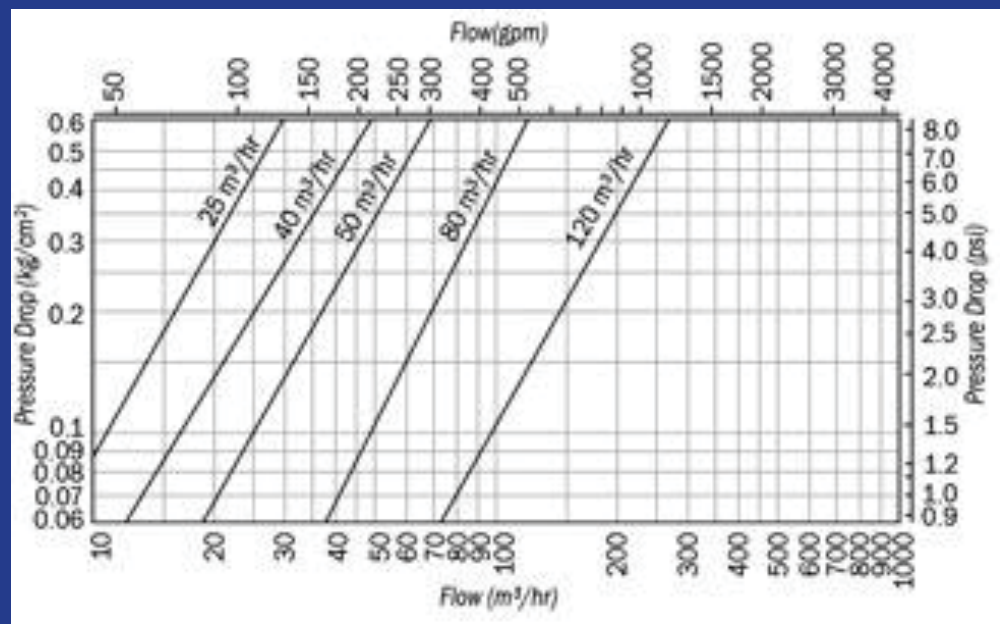

\section{Filters: Head Loss}

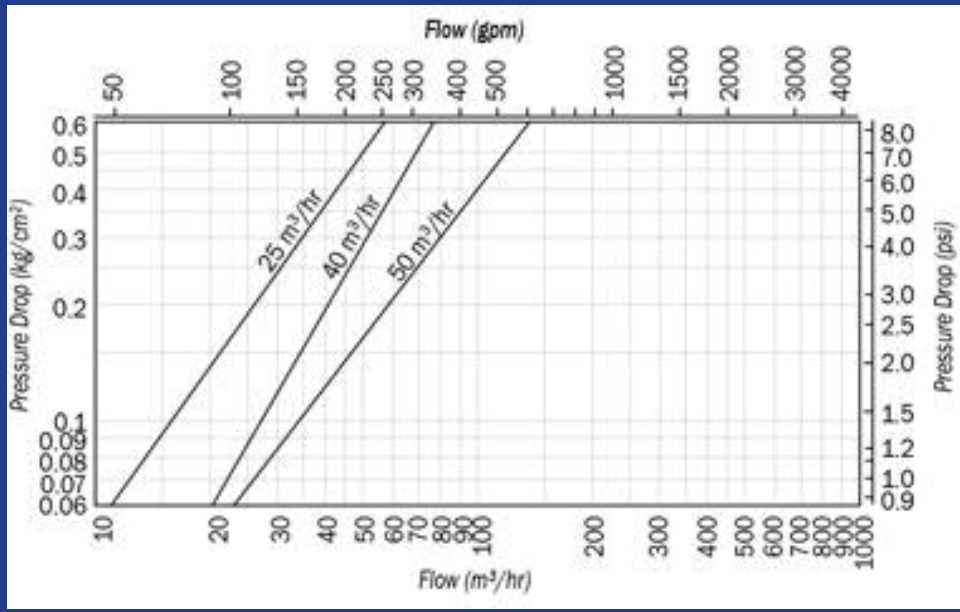

TOTAL DYNAMIC HEAD

- Emitter operating pressure

- Head loss in lateral

- Lateral Elevation

- Head loss in submains

- Head loss in Valve (assume $2 \mathrm{~m}$ )
$=10 \mathrm{~m}$

$$
\begin{aligned}
& =1.1 \mathrm{~m} \\
& =0 \mathrm{~m} \\
& =0.7 \mathrm{~m} \\
& =2.0 \mathrm{~m}
\end{aligned}
$$


- Field fitting head loss

- Head Loss in Main line

- Primary filter head loss (Gravel 2 x40 M3) .2x2

- Secondary filter head loss

(Disc $2 \times 40 \mathrm{M} 3$ )

- Fertigation equipment head loss (5 $\mathrm{m}$ for ventury)

- Water source depth

- Suction head

- Delivery head

- Safety equipment head loss

- Elevation difference

- Other losses

- Total Head Required

Say $35 \mathrm{~m}$

$$
=2.0 \mathrm{~m}
$$

$$
=0.4 \mathrm{~m}
$$

$$
=4 \mathrm{~m} \quad=4 \mathrm{~m}
$$

$.2 \times 2=4 \mathrm{~m} \quad=4 \mathrm{~m}$

$$
=5 \mathrm{~m}
$$$$
=0 \mathrm{~m}
$$$$
=1 \mathrm{~m}
$$

$=1 \mathrm{~m}$

$=2 \mathrm{~m}$

$$
\begin{aligned}
& =0 \mathrm{~m} \\
& =\mathrm{m}
\end{aligned}
$$

$$
=33.2 \mathrm{~m}
$$

\section{PUMP REQUIREMENT}

Total Flow Required $=85.531 \mathrm{~m} 3 / \mathrm{hr}=23.8 \mathrm{lps}$

Pump H.P $=\mathbf{Q}\left(\right.$ LPS) ${ }^{*} \mathbf{H}(\mathrm{m}) /(75 \times$ pump efficiency $\mathbf{x}$ motor efficiency)

$$
\begin{aligned}
& =23.8 * 35 /(75 * 0.65 * 0.9) \\
& =19
\end{aligned}
$$

\section{Say 20 H.P}

\section{Option-II (Irrigate area into Zones: Say 2 Zones)}

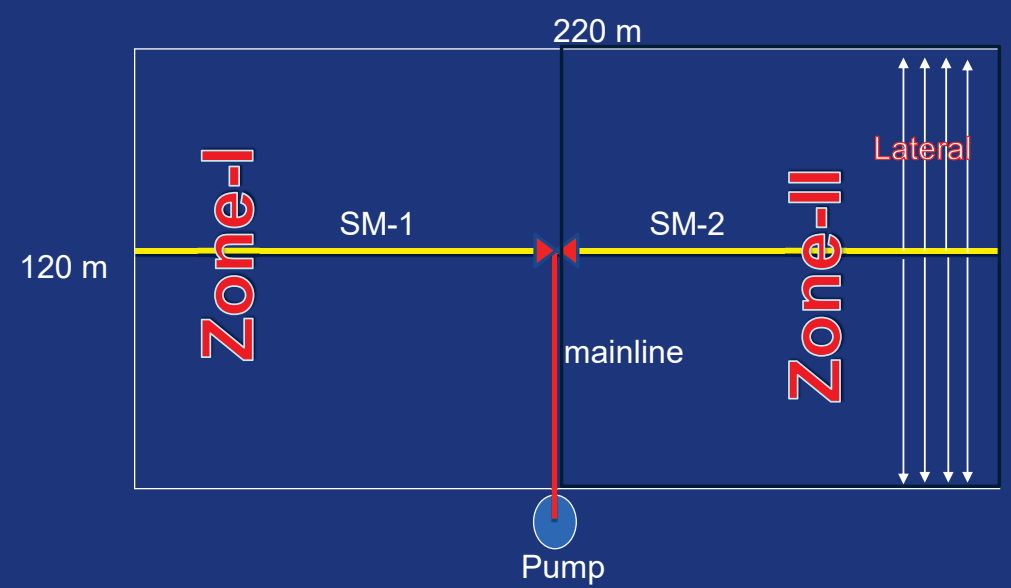




\section{Option-II (Irrigate area into Zones: Say 2 Zones)}

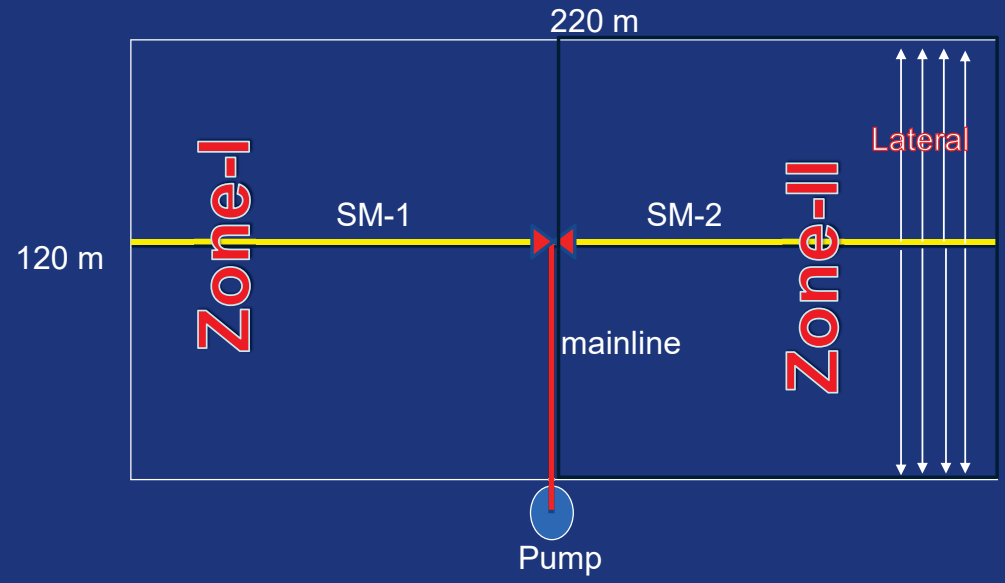

Option-III (Irrigate area into Zones: Say 4 Zones)

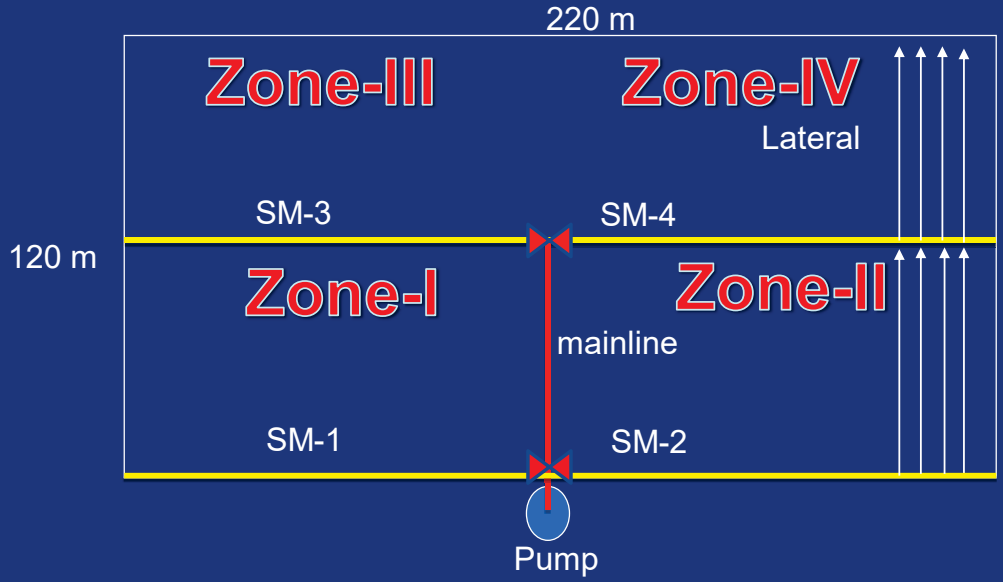




\begin{tabular}{|c|c|c|c|c|c|c|}
\hline Parameters & Unit & $\mathrm{HZ}-1$ & HZ-2 & HZ-3 & $\mathrm{HZ}-4$ & Total \\
\hline Area & Acres & 1.625 & 1.625 & 1.625 & 1.625 & 6.5 \\
\hline Peak daily consumptive use per day & Mm & 8.7 & 8.7 & 8.7 & 8.7 & 8.7 \\
\hline Total no. of plants & Nos & 14,422 & 14,422 & 14,422 & 14,422 & 57,688 \\
\hline Total drip line length & M & 4,327 & 4,327 & 4,327 & 4,327 & 17,306 \\
\hline Total no. of emitters & Nos & 10,816 & 10,816 & 10,816 & 10,816 & 43,266 \\
\hline Average emitter spacing & M & 0.4 & 0.4 & 0.4 & 0.4 & 0.4 \\
\hline Total flow rate & Lph & 21,633 & 21,633 & 21,633 & 21,633 & 21,633 \\
\hline Application rate & $\mathrm{Mm} / \mathrm{hr}$ & 3.3 & 3.3 & 3.3 & 3.3 & 0.8 \\
\hline Operation time* & hrs & 2.6 & 2.6 & 2.6 & 2.6 & 10.5 \\
\hline
\end{tabular}

Darcy- Weisbach and Blasius Equation can be combined to give accurate prediction of friction head loss for smooth plastic pipes of less than $125 \mathrm{~mm}$ (5 in.) diameter.

$$
\begin{array}{ll}
\mathbf{J}=100 & \mathbf{h f} / \mathbf{L}=\mathbf{k}^{*}\left[\left(\mathbf{Q}^{1.75}\right) /\left(\mathbf{D}^{4.75}\right)\right] \\
\mathrm{J} & =\text { Head loss gradient, } \mathrm{m} / 100 \mathrm{~m} \\
\mathrm{Hf} & =\text { pipe friction head loss, } \mathrm{m} \\
\mathrm{K} & =\text { Constant, } 7.89^{*} 10^{\wedge} 7 \text { for metric units } \\
\mathrm{Q} & =\text { Flow Rate, LPS } \\
\mathrm{L} & =\text { Pipe length, } \mathrm{m} \\
\mathrm{D} & =\text { Inside Diameter of Pipe, } \mathrm{mm}
\end{array}
$$

Darcy- Weisbach and Blasius Equation can be combined to give accurate prediction of friction head loss for smooth plastic pipes of less than $125 \mathrm{~mm}(5 \mathrm{in}$.) diameter.

$$
\begin{array}{ll}
\mathbf{J}=100 & \mathbf{h f} / \mathbf{L}=\mathbf{k}^{*}\left[\left(\mathbf{Q}^{\wedge} \mathbf{1 . 7 5}\right) /\left(\mathbf{D}^{\wedge} \mathbf{4 . 7 5}\right)\right]^{*} \mathbf{F} \\
\mathrm{J} & =\text { Head loss gradient, } \mathrm{m} / 100 \mathrm{~m} \\
\mathrm{Hf} & =\text { pipe friction head loss, } \mathrm{m} \\
\mathrm{K} & =\text { Constant, } 7.89^{*} 10^{\wedge} 7 \text { for metric units } \\
\mathrm{Q} & =\text { Flow Rate, LPS } \\
\mathrm{L} & =\text { Pipe length, } \mathrm{m} \\
\mathrm{D} & =\text { Inside Diameter of Pipe, } \mathrm{mm}
\end{array}
$$


Lateral Design:

Lateral length $=60 \mathrm{~m}$

No. of emitters $=60 / 0.4=150$

Lateral flow rate $=300 \mathrm{lph}$

Assume $13 \mathrm{~mm}$ lateral line

Inside diameter $=10 \mathrm{~mm}$

$\left.J=7.89^{*} 10^{\wedge} 7^{*}\left[(300 / 3600)^{\wedge} 1.75\right) /\left(10^{\wedge} 4.75\right)\right] * 0.36$

$\mathrm{J}=6.53 \mathrm{~m} / 100 \mathrm{~m}$

For $60 \mathrm{~m}$ length

$\mathrm{Hf}=3.92 \mathrm{~m}$

Lateral Design:

Lateral length $=60 \mathrm{~m}$

No. of emitters $=60 / 0.4=150$

Lateral flow rate $=300 \mathrm{lph}$

Assume $16 \mathrm{~mm}$ lateral line

Inside diameter $=13 \mathrm{~mm}$

$\left.J=7.89^{*} 10^{\wedge} 7^{*}\left[(300 / 3600)^{\wedge} 1.75\right) /\left(13^{\wedge} 4.75\right)\right]^{*} 0.36$

$\mathrm{J}=1.9 \mathrm{~m} / 100 \mathrm{~m}$

For $60 \mathrm{~m}$ length

$\mathrm{Hf}=1.1 \mathrm{~m}$

Sub-Mainline Design:

Length $=120 \mathrm{~m}$

No. of laterals $=120 / 1.52=79$

Sub-main flow rate $=86531 / 4$

$=21,633 \mathrm{Iph}$

Assume $70 \mathrm{~mm}$ lateral line

Inside diameter $=63 \mathrm{~mm}$

$\left.J=7.89^{*} 10^{\wedge} 7^{*}\left[(21,633 / 3600)^{\wedge} 1.75\right) /\left(63^{\wedge} 4.75\right)\right]^{*} 0.36$

$\mathrm{J}=1.9 \mathrm{~m} / 100 \mathrm{~m}$

For $120 \mathrm{~m}$ length

$\mathrm{Hf}=2.2 \mathrm{~m}$

Darcy- Weisbach and Blasius Equation can be combined to give accurate prediction of friction head loss for smooth plastic pipes of less than $125 \mathrm{~mm}$ (5 in.) diameter.

$J=100 \mathrm{hf} / \mathrm{L}=k^{*}\left[\left(Q^{\wedge} 1.75\right) /\left(D^{\wedge} 4.75\right)\right]$

$\mathrm{J}=$ Head loss gradient, $\mathrm{m} / 100 \mathrm{~m}$

$\mathrm{Hf} \quad=$ pipe friction head loss, $\mathrm{m}$

$\mathrm{K}=$ Constant, $7.89 * 10^{\wedge} 7$ for metric units

$\mathrm{Q} \quad=$ Flow Rate, LPS 
$\mathrm{L} \quad=$ Pipe length, $\mathrm{m}$

D = Inside Diameter of Pipe, $\mathrm{mm}$

Mainline Design:

Length $=60 \mathrm{~m}$

Sub-main flow rate $=86531 \mathrm{LPH}$

Assume $90 \mathrm{~mm}$ Sub-Mainline

Inside diameter $=87 \mathrm{~mm}$

$\left.J=7.89^{*} 10^{\wedge} 7^{*}\left[(21633 / 3600)^{\wedge} 1.75\right) /\left(87^{\wedge} 4.75\right)\right]$

$\mathrm{J}=1.1 \mathrm{~m} / 100 \mathrm{~m}$

For $60 \mathrm{~m}$ length

$\mathrm{Hf}=0.7 \mathrm{~m}$

\section{Velocity of Mainline}

$v=1.274 q / d^{2}$

where

$v=$ velocity $(\mathrm{m} / \mathrm{s})$

$q=$ volume flow $\left(m^{3} / s\right)$

$d=$ pipe inside diameter $(m)$

$V=1.274 \times\left[\left(21633 /\left(1000^{*} 3600\right)\right] /\left[(87 / 1000)^{\wedge} 2\right]\right.$

$=1.01 \mathrm{~m} / \mathrm{s}$ 


\section{Filters: Head Loss}

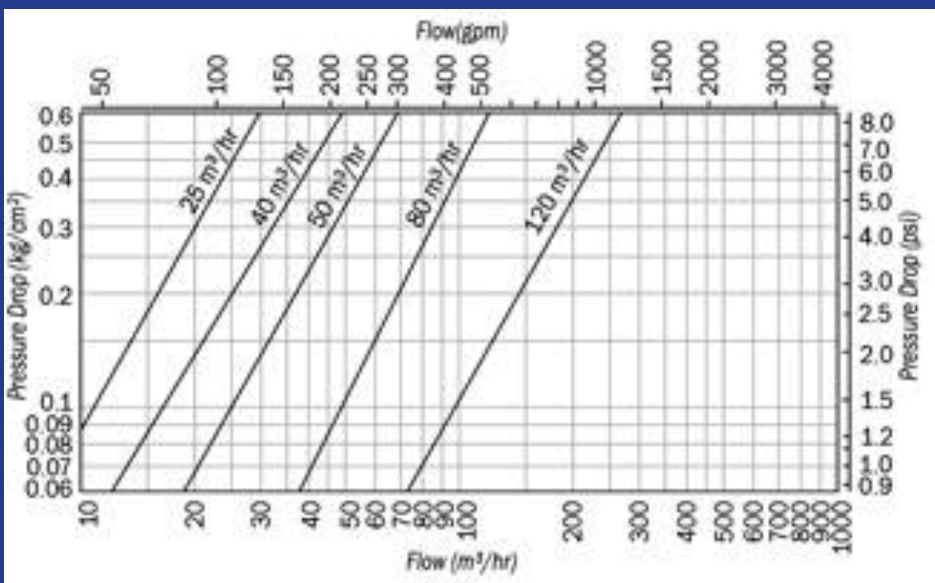

Source: Jain Hydro-cyclone Filter

\section{Filters: Head Loss}

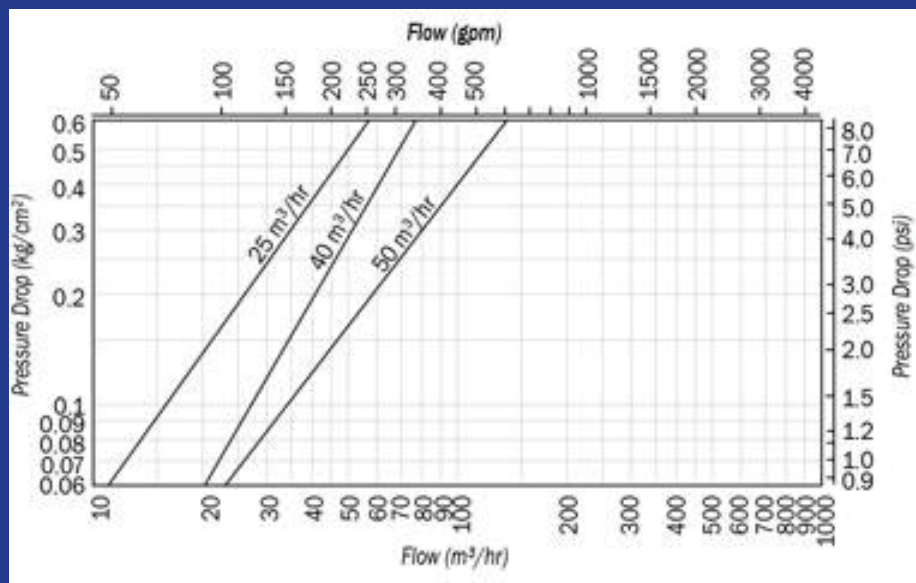

Source: Jain Media Filter 


\section{Filters: Head Loss}

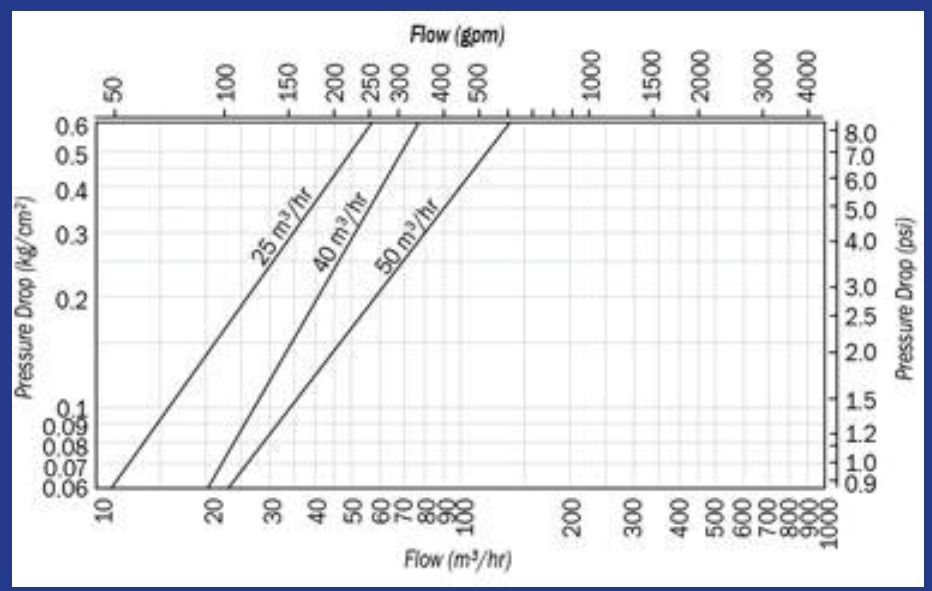

Source: Jain Media Filter

- Emitter operating pressure

- Head loss in lateral

- Lateral Elevation

- Head loss in submains

- Head loss in Valve (assume $2 \mathrm{~m}$ )

- Field fitting head loss

- Head Loss in Main line

- Primary filter head loss (Gravel $20 \mathrm{m3}$ )

- Secondary filter head loss (Disc $20 \mathrm{m3}$ )

- Fertigation equipment head loss (5 $\mathrm{m}$ for ventury)

- Water source depth

- Suction head

- Delivery head

- Safety equipment head loss

- Elevation difference

- Other losses

- Total Head Required
$=10 \mathrm{~m}$

$=1.1 \mathrm{~m}$

$=0 \mathrm{~m}$

$$
=2.2 \mathrm{~m}
$$$$
=2.0 \mathrm{~m}
$$

$=2.0 \mathrm{~m}$

$$
\begin{aligned}
& =0.7 \mathrm{~m} \\
& =1.5 \mathrm{~m} \\
& =1.3 \mathrm{~m} \\
& =5 \mathrm{~m}
\end{aligned}
$$

$=0 \mathrm{~m}$

$=1 \mathrm{~m}$

$=1 \mathrm{~m}$

$=2 \mathrm{~m}$

$=0 \mathrm{~m}$

$=\mathrm{m}$

$=29.8 \mathrm{~m}$

\section{Say $30 \mathrm{~m}$}

Total Flow Required $=21.382 \mathrm{~m} 3 / \mathrm{hr}=\mathbf{5 . 9 4} \mathrm{Ips}$

$$
\begin{aligned}
\text { Pump H.P }=Q(\text { LPS }) & * H(\mathrm{~m}) /(75 \times \text { pump efficiency } \times \text { motor efficiency }) \\
& =5.94 * 30 /(75 * 0.65 * 0.9) \\
& =4.1
\end{aligned}
$$

Say 5 H.P 


\subsection{DESIGN OF SPRINKLER IRRIGATION SYSTEM}

A pressurized irrigation system is a network of installation consisting of pipes, fittings and other devices properly designed and installed to supply water under pressure from the source of the water to the irrigable area.

\section{Two main classification:}
$\bullet$
Sprinkler Irrigation
- $\quad$ Micro/Drip Irrigation

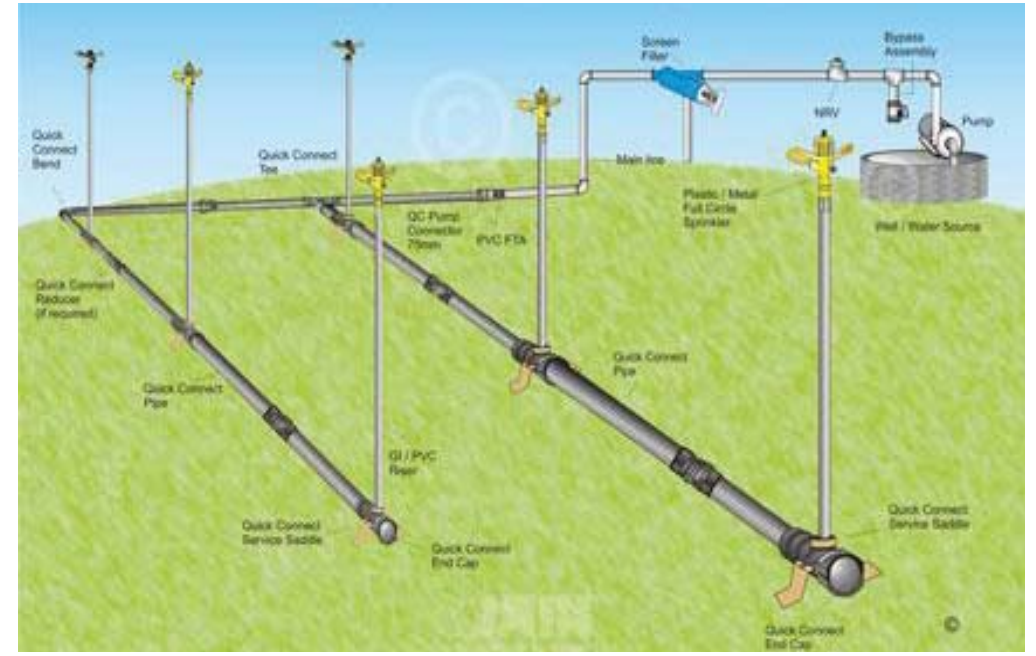

\section{Typical Sprinkler Irrigation System Layout}

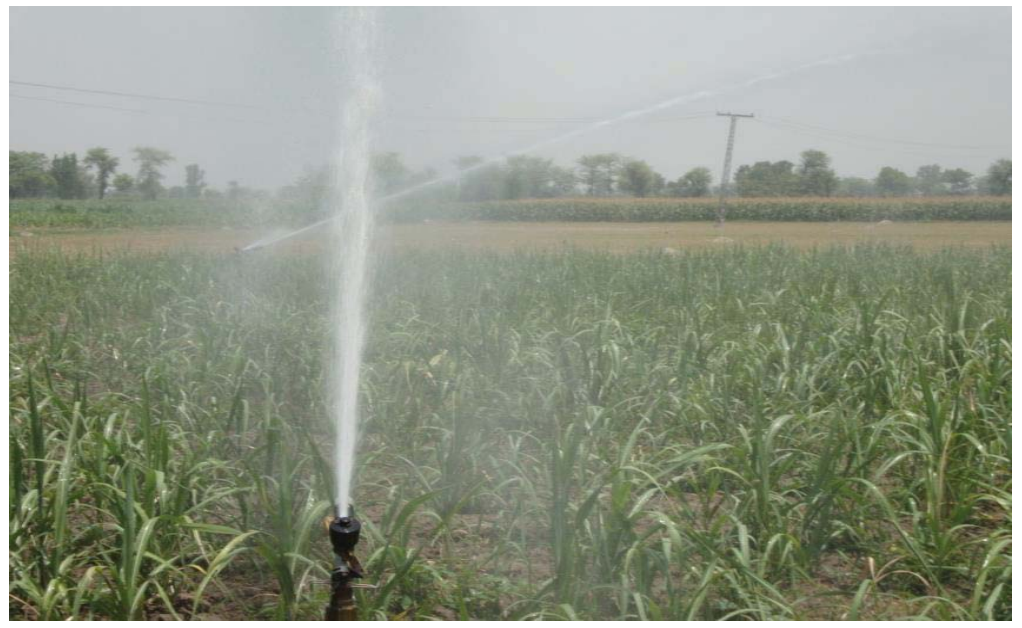

Piped irrigation systems are classified according to the pressure required for operation, the method of delivering water to plants, and the type of installation

PRESSURE: it is the maximum water pressure required for normal system operation 
- Low Pressure System: 2.0 to 3.5 bars

- Medium Pressure System: 3.5 to 5.0 bars

- High Pressure System: > 5.0 bars

\section{TYPE OF INSTALLATION}

- Solid Installation (all components are installed at fixed positions)

- Semi- solid installation (Main and submain are permanent, lateral are portable, hand move or mechanical move)

- Portable (all component parts are portable)

\section{WATER DELIVERY METHOD}

- Sprinkler (Over head irrigation)

- Micro-irrigation (Localized irrigation) by dripper, bubblers, micro jets etc

Sprinkler irrigation is the method where water is sprayed through the air and it falls to the ground like rain. The spray is obtained by the flow of water under pressure through small orifices or nozzles known as sprinklers. Water is conveyed from the pump and distributed through a network of pipes called mainline, sub-mainlines, laterals and sprinklers.

\section{Advantages}

Sprinkler irrigation is suitable for all crops except rice as it requires standing water.

Water can be spread over row crops and under canopy of tree crops.

- Large sprinklers are not suitable for delicate flowering and fruiting plants because larger water drops may damage the crop.

- Suitable to complete range of topography

- Land leveling not required

- Light textured soil which cannot be irrigated properly by surface irrigation can be effectively irrigated.

- Higher irrigation efficiency can be achieved through proper designing

- Soluble fertilizers can be applied through foliar application

- Easy to operate

- Less sensitive to clogging.

- High efficiency can be achieved with a proper design

\section{Disadvantages}

$\square$ Very sensitive to wind conditions

$\square$ Higher evaporation rate

$\square$ Fine textured soil having very low infiltration rates cannot be irrigated efficiently

$\square$ Few crops with delicate flowering cannot be irrigated with sprinkler system

$\square$ Use of low quality water may cause leaf burn

$\square$ Must work under pressure, according to the manufacturer's recommendations to obtain good results 
- Two Basic Groups

- Set System

- Periodic move systems

- Hand move lateral, End-Tow Lateral, Rain Gun system, Boom sprinklers etc.

- Fixed system

- Lateral lines and sprinkler heads are fixed

- Continuous move systems

- Center Pivot system

- Linear Move system

\section{CLASSIFICATION OF SPRINKLERS AND APPLICABILITY}

Classification of sprinkler heads based on operating pressure

$$
\begin{array}{lccc}
\text { Agriculture sprinklers } & \begin{array}{c}
\text { Operating } \\
\text { pressure (bars) }
\end{array} & \begin{array}{c}
\text { Flow rate } \\
\left(\mathrm{m}^{3} / \mathrm{h}\right)
\end{array} & \begin{array}{c}
\text { Diameter } \\
\text { coverage }(\mathrm{m})
\end{array}
\end{array}
$$

Low pressure

Medium pressure

High pressure
$1.5-2.5$

2.5-3.5

$4.0-9.0$
$0.3-1.5$

$1.5-3.0$

$5.0-45.0$
$12-21$

24.35

60-80

The initial cost and the labor required are both directly related to the portability of a sprinkler system. The more portable a system, the lower the initial cost and the higher the labor requirements to operate it Conversely, the permanent system has the highest initial cost and lowest labor requirements. Each person selecting a sprinkler system has his own set of circumstances and economic conditions to consider.

The selection of a system is an economic compromise of these individual conditions. and no two may be exactly alike However, after the type of system has been selected, there is a basic common guideline to follow in developing the details of the system 

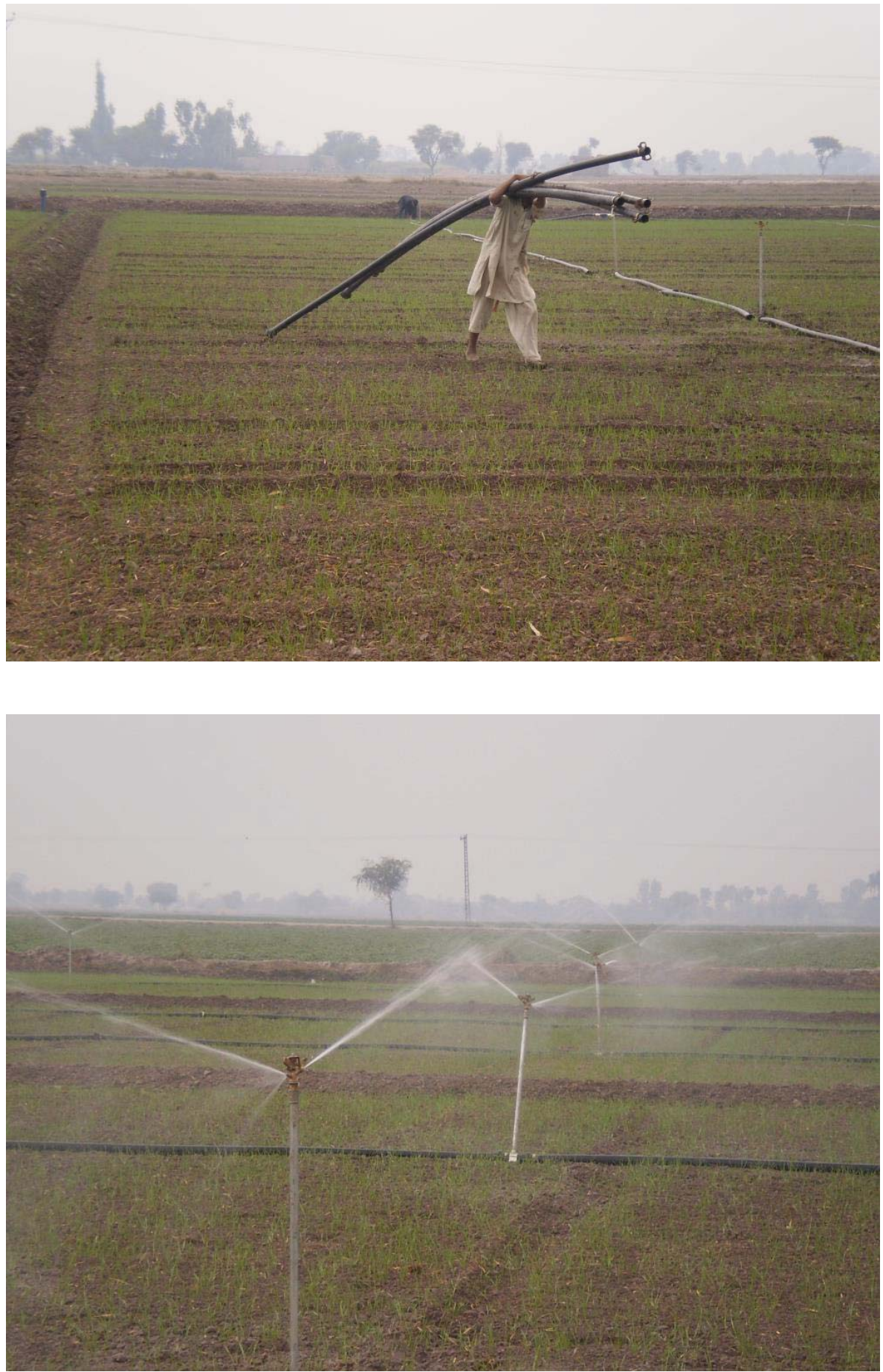

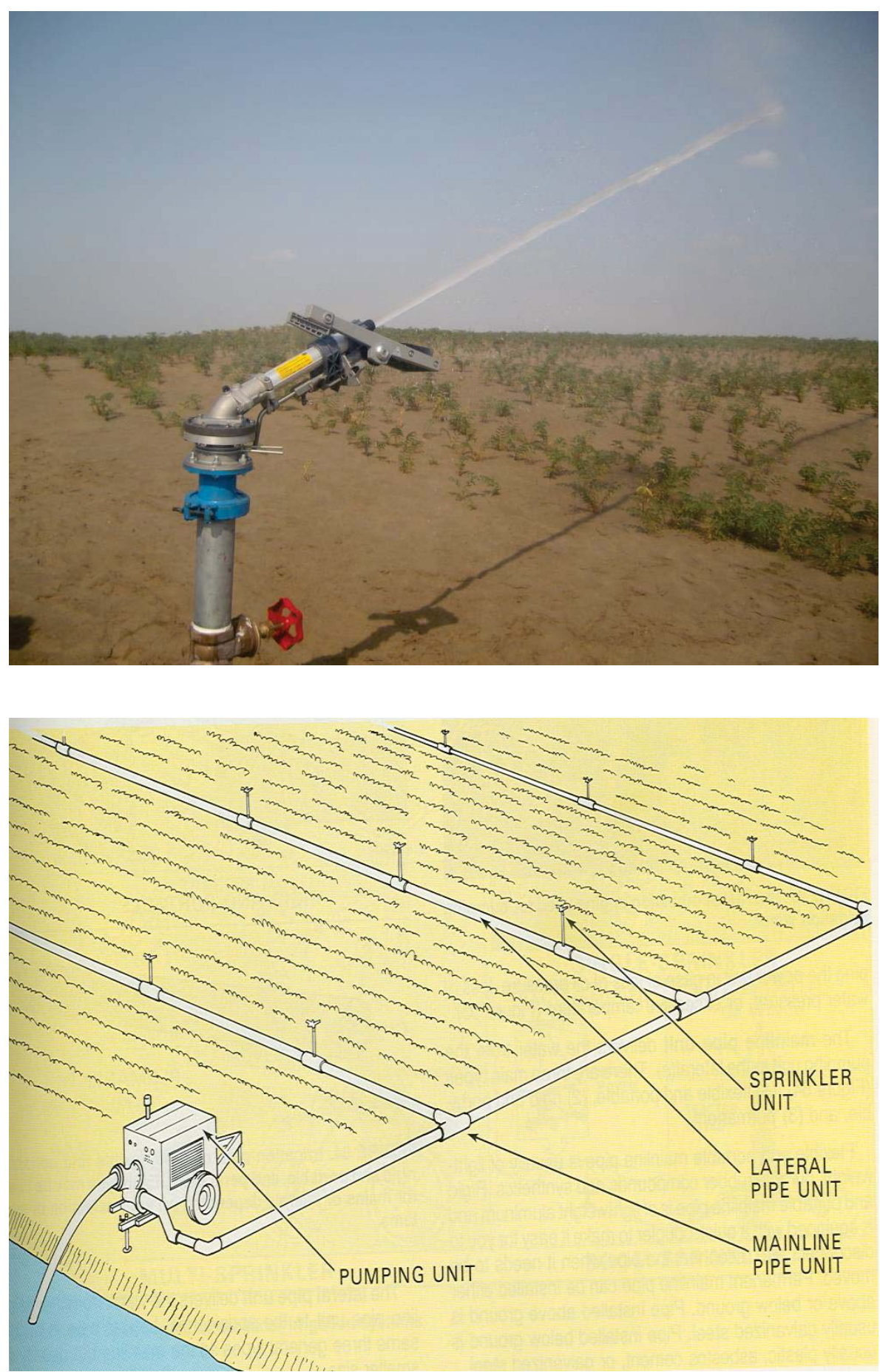


\subsubsection{Components of Sprinkler System}

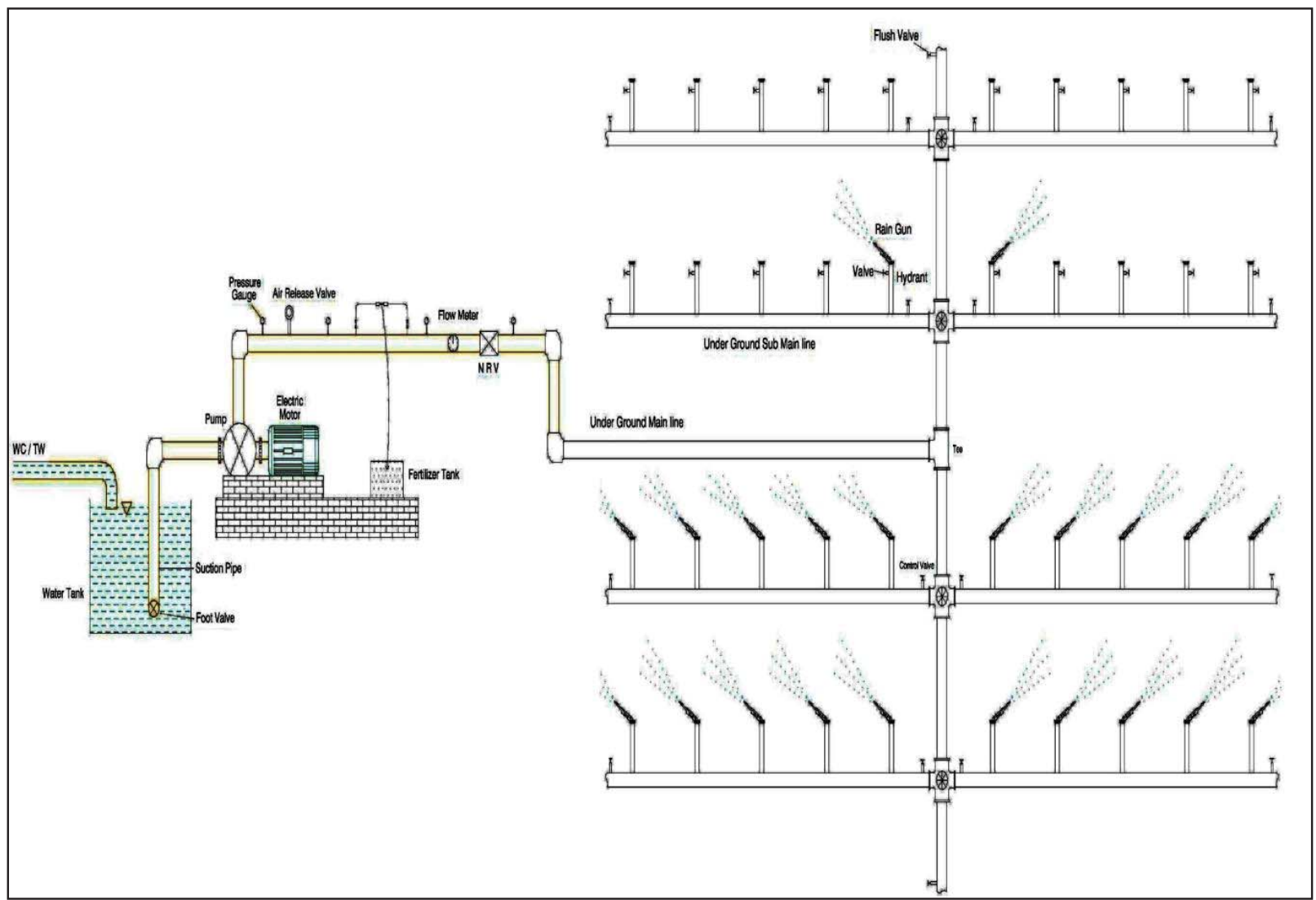

\section{A. PUMP SET}

$\square$ Centrifugal/deep-well turbine pumps may be used.

$\square$ May be powered by electric motors or internal combustion engines using diesel, gasoline or natural gas.

\section{B. Main pipeline, Sub-mains \& Laterals}

$\square$ To convey water from the pumping unit to the laterals.

$\square$ Laterals may be directly connected to the main line without any sub-main line.

$\square$ Generally made of UPVC and HDPE

$\square$ Generally made of UPVC and HDPE

\section{Laterals}

- receive water from the main pipeline or sub-main to the sprinklers.

- Usually made of uPVC, HDPE

\section{Riser/Hydrants}

$\square$ To connect sprinkler head to the lateral pipe.

$\square$ Height of riser pipe depends upon the height of crop to be irrigated and sprinkler flow rate.. 
$\square$ Generally made of Aluminum, GI

\section{E. Valves \& Safety Equipment}

$\square$ Flow control valve: To divert flow from mainline to sub-mainline

$\square$ Check/NRV valves: on the discharge side of the pump so that if the pump is shut off it should maintain water in the pipeline above the pump.

$\square$ Foot-valve: on the bottom of the suction pipe

$\square$ Pressure Gauges: To monitor system pressure

$\square$ Flow Meter: to record amount of water passing

\subsection{SPRINKLER SYSTEM TECHNICAL ASPECT}

\section{i. Discharge from Sprinkler Nozzle}

Theoretical discharge from sprinkler nozzle can be computed from orifice flow equation:

$q=c d a \sqrt{2 g h}$

$\mathrm{q}=$ nozzle discharge, $\mathrm{m} 3 / \mathrm{sec}$

$\mathrm{a} \quad=\mathrm{x}$ - sectional area of sprinkler nozzle, $\mathrm{m} 2$

$\mathrm{h}=$ pressure head at the nozzle, $\mathrm{m}$

$\mathrm{Cd}=$ coefficient of discharge as a function of friction and contraction (ranges from 0.8 to 0.98 : larger the nozzle, lower the coefficient)

$\mathrm{g}=$ =acceleration due to gravity, $\mathrm{m} / \mathrm{sec} 2$

\section{ii. Wetted Area of Sprinkler}

\section{$A=\lambda R$ \\ $R=1.35 \sqrt{d h}$}

A $\quad=$ Area covered by the sprinkler, $\mathrm{m}^{2}$

$\mathrm{R} \quad=$ Radius of weter area, $\mathrm{m}$

$\mathrm{d}=$ Diameter of sprinkler nozzle, $\mathrm{mm}$

$\mathrm{h} \quad=$ Pressure head at nozzle, $\mathrm{m}$

\section{iii. Distribution Uniformity}

$E d=\left(1-\frac{y}{d}\right) \cdot 100$

Indicates the extent to which water is uniformly distributed. 


\section{Ed = Water distribution efficiency, $\%$ \\ $\mathrm{d}=\quad$ Average depth of water stored \\ $\mathrm{y} \quad=\quad$ Average numerical deviation from $\mathrm{d}$}

\section{iv. Application Rate of Sprinkler}

The rate at which sprinkler apply water on soil surface. Application rate depends on:

- Size of sprinkler nozzle

- Operating pressure

- Spacing between sprinklers

$I=\frac{q}{S l x S m}$

I = Application rate, $\mathrm{mm} / \mathrm{hr}$

q = Discharge, Iph

$\mathrm{Sm} \quad=$ Sprinkler spacing along sub-mainline, $\mathrm{m}$

$\mathrm{SI}=$ Sprinkler spacing on lateral, $\mathrm{m}$

\section{v. Capacity Requirement}

$Q=\frac{2.78 A d}{f T}$

Q = System Discharge Capacity, Ips

A = design area (ha)

$\mathrm{D} \quad=$ gross depth of application $(\mathrm{mm})$

$\mathrm{f} \quad=$ Time allowed for completion of irrigation (days)

$\mathrm{T}=$ Actual operating time (hrs/day)

\section{vi. Minimum Number of Sprinklers Operating}

$$
\begin{aligned}
& \text { Nn= } \frac{Q}{q} \\
& \mathrm{Nn} \quad=\text { Minimum average number of sprinkler operating } \\
& \mathrm{q} \quad=\text { average sprinkler discharge }
\end{aligned}
$$

\section{vii. Wind Effect on the Diameter of Throw}

For 0-3 mph wind:

reduce manufacturer's listed diameter of throw by $10 \%$ for an effective value (i.e. the diameter where the application of water is significant)

over 3 mph wind: 
reduce manufacturer's listed diameter of throw by an additional $2.5 \%$ for every 1 mph above $3 \mathrm{mph}(5.6 \%$ for every $1 \mathrm{~m} / \mathrm{s}$ over $1.34 \mathrm{~m} / \mathrm{s})$

\section{viii. Wind Effect on The Diameter of Throw}

For 0-3 mph (0-1.34 m/s):

$$
\text { diam }=0.9 \text { diammanuf }
$$

For $>3 \mathrm{mph}(>1.34 \mathrm{~m} / \mathrm{s})$ :

$$
\text { diam }=\text { diammanuf }[0.9-0.025(\text { windmph }-3)]
$$

Example: a manufacturer gives an 80 -ft diameter of throw for a certain sprinkler and operating pressure. For a $5 \mathrm{mph}$ wind, what is the effective diameter?

$$
\begin{aligned}
& 80 \mathrm{ft}-(0.10)(0.80)=72 \mathrm{ft} \\
& \text { diam }=80(0.9-0.025(5-3))=68 \mathrm{ft}
\end{aligned}
$$

\section{SPRAY PATTERN: VARIATION IN PRESSURE}

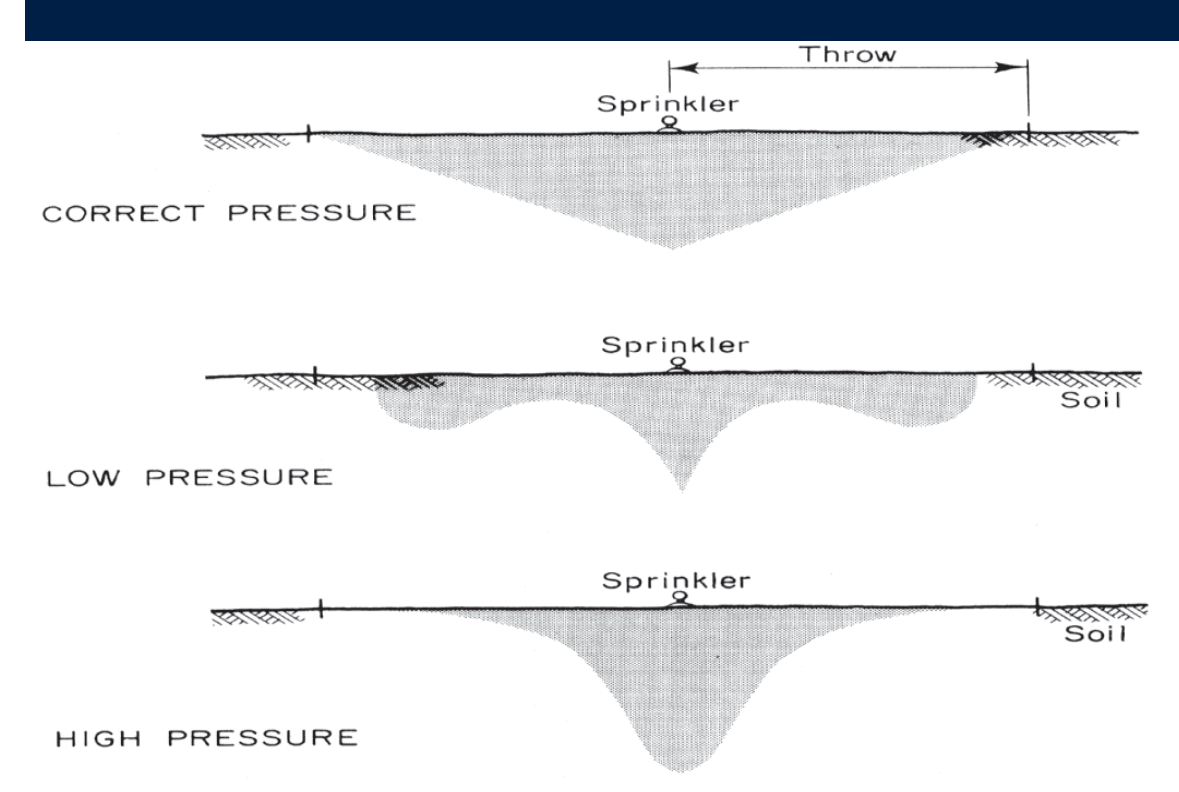

\section{ix. Overlapping}

Distribution pattern of a single sprinkler is not uniform throughout the radius and also affects drastically by wind. To minimize the effect of wind and provide uniform depth of water on the area under sprinkler irrigation system, distance between the sprinklers is reduced in such a way that water from one sprinkler reaches approximately to the adjacent sprinkler. 

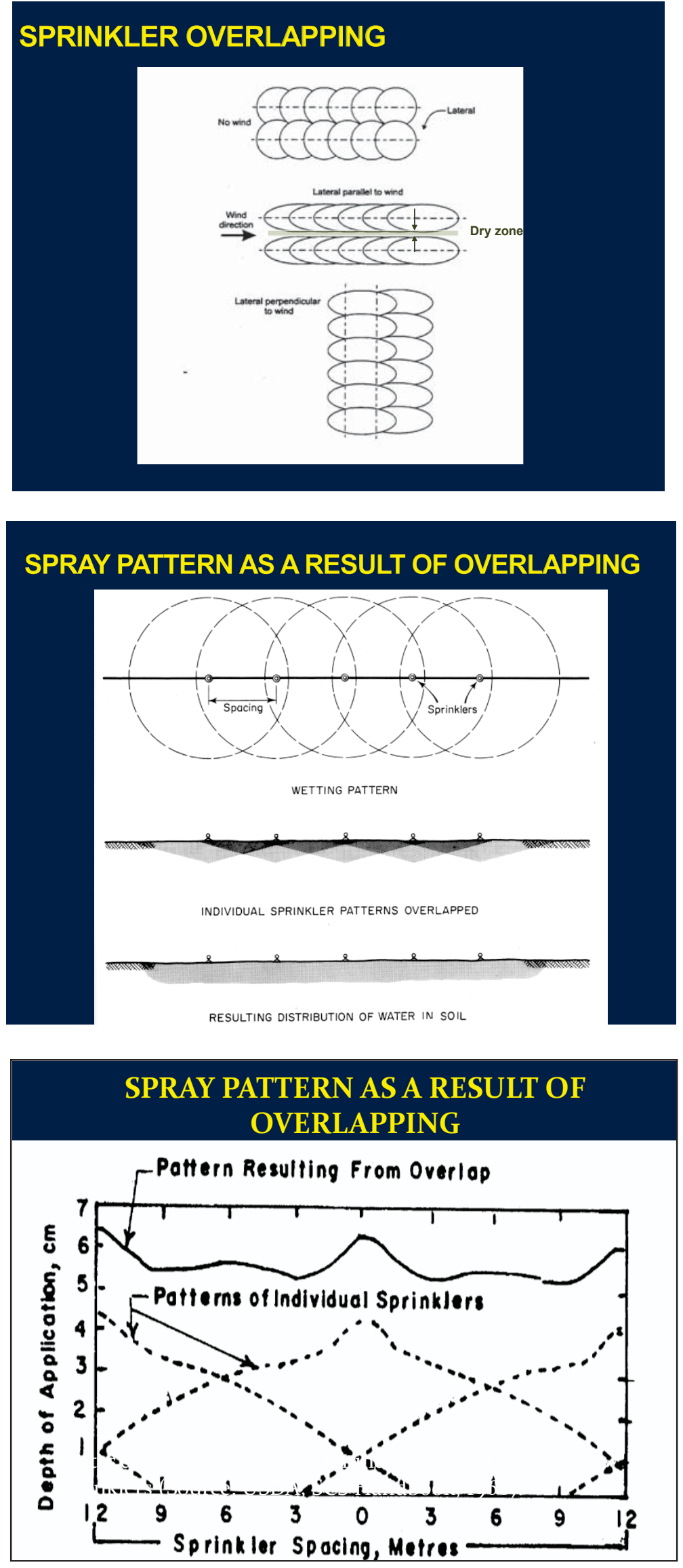


\title{
DIFFERENT PATTERN OF SPRINKLER PLACEMENT
}

\section{RECTANGULAR SPACING}

\section{Sprinkler spacing at lateral} $40 \%$ of effective diameter Lateral Spacing $67 \%$ of the effective diameter

(For big volume Rain Gun lateral spacing should not exceed $65 \%$ of effective diameter and sprinkler spacing at lateral should be $50 \%$ of effective wetted diameter)

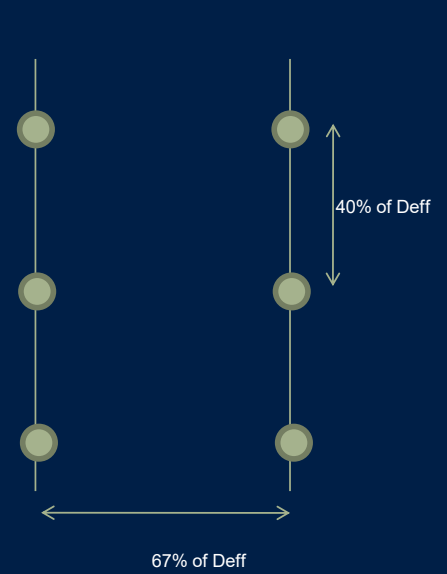

\section{SQUARE SPACING}

\author{
Sprinkler spacing at lateral \\ $50 \%$ of effective diameter \\ Lateral Spacing \\ $50 \%$ of the effective diameter
}




\section{TRIANGULAR SPACING}

Sprinkler spacing at lateral $62 \%$ of effective diameter Lateral Spacing $54 \%$ of the effective diameter

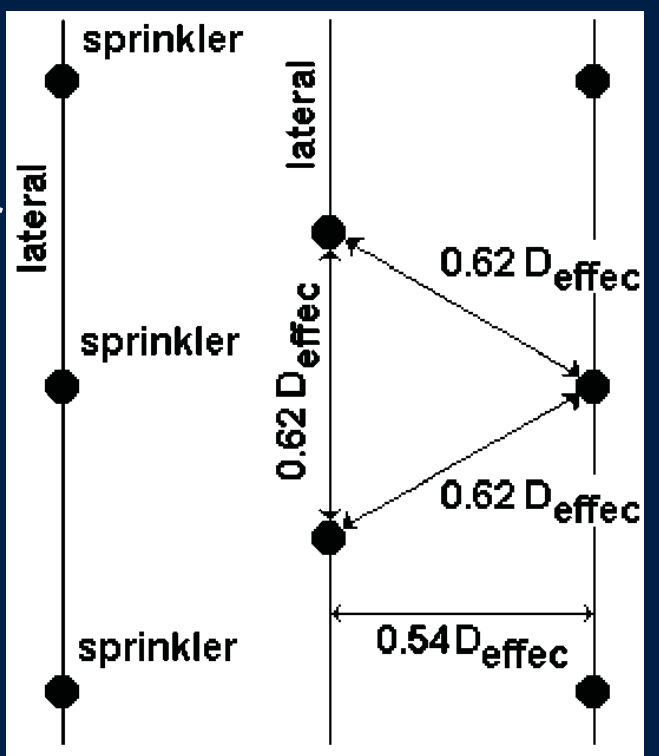

\section{OVERLAPPING PATTERNS}

\section{DIFFERENT SPACING OF LATERALS}

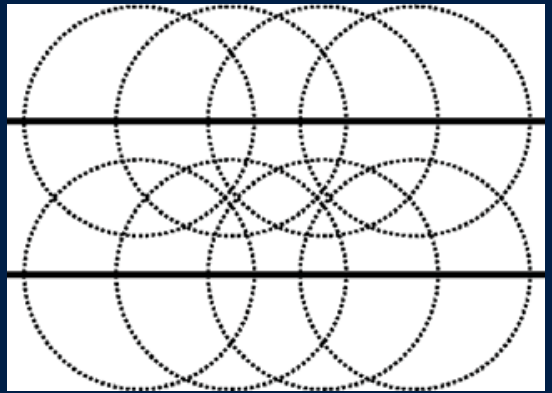

Rectangular: $40 \%$ x $67 \%$

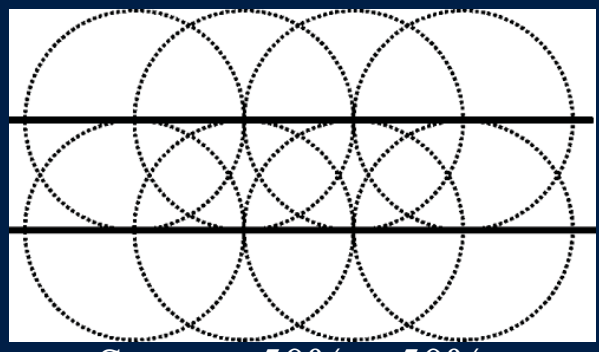

Square: $50 \% \times 50 \%$

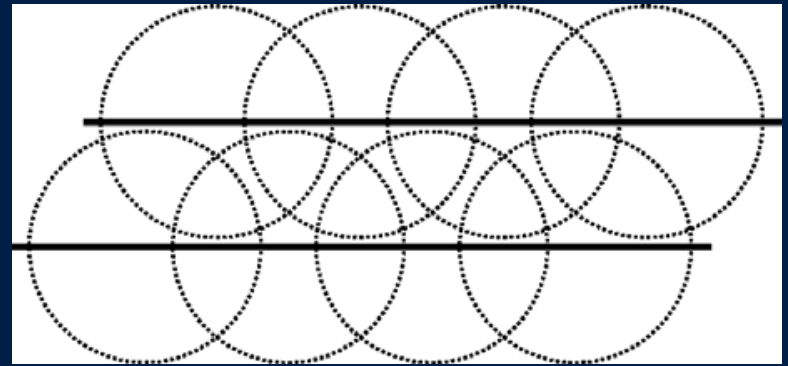

Triangular: $62 \%$ x 54\% 


\section{HYDRANT/RISER HEIGHT}

Riser pipes elevate and support the sprinklers above the crop Provide connecting link to the lateral.

\begin{tabular}{|c|c|}
\hline $\begin{array}{c}\text { Sprinkler Discharge } \\
\text { (1ps) }\end{array}$ & $\begin{array}{c}\text { Minimum Riser } \\
\text { height }(\mathrm{cm})\end{array}$ \\
\hline < 0.6 & 15 \\
\hline 0.6 to 1.6 & 23 \\
\hline 1.6 to 3.2 & 30 \\
\hline 3.2 to 7.6 & 45 \\
\hline$>7.6$ & 90 \\
\hline
\end{tabular}

\section{SUGGESTED MAXIMUM SPRINKLER APPLICATION RATE}

\begin{tabular}{l|l|l|l|l|}
\hline \multicolumn{1}{c|}{$\begin{array}{c}\text { Soil } \\
\text { texture }\end{array}$} & \multicolumn{5}{|c|}{ Maximum application rate (mm/hr) } \\
\hline & 0 to $5 \%$ & 5 to $8 \%$ & 8 to $12 \%$ & 12 to $16 \%$ \\
\hline $\begin{array}{l}\text { Coarse sandy } \\
\text { soil }\end{array}$ & 50 & 38 & 25 & 13 \\
\hline $\begin{array}{l}\text { Light sandy } \\
\text { loam }\end{array}$ & 25 & 20 & 15 & 10 \\
\hline $\begin{array}{l}\text { Silty loam } \\
\text { Heavy }\end{array}$ & 4 & 10 & 8 & 5 \\
\hline textured clay & 4 & 2.5 & 2 & 1.5 \\
\hline
\end{tabular}




\section{PERFORMANCE CHART FOR MEDIUM VOLUME RAIN GUN}

\begin{tabular}{|c|c|c|c|c|c|c|c|c|c|c|c|c|c|c|c|}
\hline \multicolumn{10}{|c|}{ Performance Chart for Model $162 \& 163$} & \multicolumn{6}{|c|}{ Trajectory - for $162-30$, for $163-23$} \\
\hline \multirow{3}{*}{$\begin{array}{l}\text { "Pressure } \\
\mathrm{kg} / \mathrm{mm}^{2}\end{array}$} & \multicolumn{3}{|c|}{ Nozzle $08 \mathrm{~mm}$} & \multicolumn{3}{|c|}{ Nozle $010 \mathrm{~mm}$} & \multicolumn{3}{|c|}{ Nozzle $012 \mathrm{~mm}$} & \multicolumn{3}{|c|}{ Nogrle $014 \mathrm{~mm}$} & \multicolumn{3}{|c|}{ Nozzle $016 \mathrm{~mm}$} \\
\hline & Radius & Discharge & ppot. rate & Radius & Discharge & ppt.rate & Radus & Discharge & pptrate & Padius & Discharge & pptrate & Padilus & Discharge & pptrate \\
\hline & $m$ & $1 / \mathrm{s}$ & inch/hr & III & $1 / 0$ & inch//hr & $m$ & $1 / 2$ & IIIMa/fin & $m$ & $1 / \mathrm{s}$ & inch/hr & $\mathrm{m}$ & $1 / 5$ & inch/h $/ \mathrm{h}$ \\
\hline 200 & 19.50 & Lul & . & L1., & 100 & & & 2.02 & & 24.WW & .21 & & 2T.NO & .1 .17 & 0.32 \\
\hline 300 & 22.0 & 167 & 0.10 & 24.6 & L.VI & & 20. & 0. & V.LL & 27.50 & 7.011 & & 0.50 & jol & 029 \\
\hline 4.00 & 24.00 & 1.93 & 0.15 & 26.50 & 2.67 & 0.10 & 28.50 & 3.51 & 0.21 & 30.00 & 4.63 & 0.24 & 31.50 & 5.86 & 0.27 \\
\hline 5.00 & 25.50 & 2.16 & 0.15 & 28.50 & 2.98 & 0.17 & 30.50 & 3.99 & 0.20 & 32.00 & 5.18 & 0.24 & 33.50 & 6.55 & 0.27 \\
\hline 6.00 & - & & & - & & & 32.50 & 4.37 & 0.19 & 33.50 & 5.67 & 0.23 & 34.50 & 7.17 & 028 \\
\hline
\end{tabular}

Note: The Performance data are based on ideal test conditions and may be adversyly affected by wind, poor hydraulic entrance. ${ }^{\star}$ The pressure refers to pressure a t nozzle

\section{Performance Data - Metric Units}

\begin{tabular}{|c|c|c|c|c|c|c|c|c|c|c|c|c|}
\hline \multirow[b]{2}{*}{ Anpros } & \multicolumn{12}{|c|}{ MOZLF SIII } \\
\hline & & 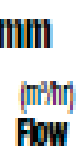 & & $\begin{array}{l}\text { ImIIII } \\
\text { minhin } \\
\text { Flow }\end{array}$ & $\begin{array}{l}18 \\
\text { (imi) } \\
\text { had. }\end{array}$ & 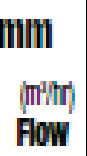 & $\begin{array}{c}20 \\
20 \\
\text { [imi } \\
\text { Hiad. }\end{array}$ & & & $\begin{array}{l}\text { Imint } \\
\text { (nifhth) } \\
\text { Flaw }\end{array}$ & & \\
\hline & 31,4 & 12,5 & 32,0 & 16,4 & 34,4 & 20,9 & 39,9 & 25,9 & 36,4 & 30,4 & 38,4 & 36 \\
\hline $\mathrm{w}$ & 33,2 & 13,8 & 33,8 & 17,9 & 37,8 & 22,9 & 41,8 & 28,2 & 41,5 & 33,6 & 41,8 & 40,2 \\
\hline 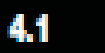 & 35,1 & 15,0 & 36,6 & 19,5 & 40,5 & 25,0 & 43,0 & 30,9 & 42,7 & 36,8 & 43,3 & 43,9 \\
\hline 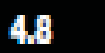 & 36,9 & 16,4 & 38,4 & 21,1 & 42,7 & 26,8 & 44,5 & 33,4 & 45,4 & 39,8 & 46,0 & 47,5 \\
\hline 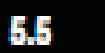 & 39,0 & 17,5 & 39,0 & 22,5 & 44,5 & 28,9 & 46,6 & 35,7 & 48,1 & 42,7 & 50,6 & 50,8 \\
\hline & 40,8 & 18,6 & 41,1 & 24,1 & 46,0 & 30,9 & 48,5 & 38,2 & 51,2 & 45,7 & 53,3 & 54,5 \\
\hline & 42,7 & 20,0 & 43,0 & 25,7 & 46,9 & 32,7 & 50,0 & 40,4 & 53,6 & 48,6 & 56,1 & 57,8 \\
\hline
\end{tabular}




\section{PERFORMANCE CHART FOR BIG VOLUME RAIN GUN}

\begin{tabular}{|c|c|c|c|c|c|c|c|c|c|c|c|c|c|c|}
\hline \multicolumn{11}{|c|}{ Twin 101} & \multicolumn{2}{|c|}{ Taper bore nozzle } & \multicolumn{2}{|c|}{ Trajectory $24^{0}$} \\
\hline \multirow{2}{*}{$\begin{array}{l}\text { Pressure } \\
\text { ise }\end{array}$} & \multicolumn{2}{|c|}{$\begin{array}{c}\text { Morle } \\
12 \mathrm{~mm}-0.4 \mathrm{~T}\end{array}$} & \multicolumn{2}{|c|}{$\begin{array}{c}\text { Morde } \\
14 \mathrm{~mm}-0.55^{\prime \prime}\end{array}$} & \multicolumn{2}{|c|}{$\begin{array}{c}\text { Norzle } \\
16 \mathrm{~mm}-0.63 \mathrm{~s}^{\prime}\end{array}$} & \multicolumn{2}{|c|}{ 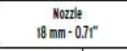 } & \multicolumn{2}{|c|}{$\begin{array}{c}\text { Horzle } \\
20 \mathrm{~mm}-0.79\end{array}$} & \multicolumn{2}{|c|}{$\begin{array}{c}\text { Mozle } \\
22 \mathrm{~mm}-0.87 "\end{array}$} & \multicolumn{2}{|c|}{$\begin{array}{c}\text { Monle } \\
24 \text { min-0.94" }\end{array}$} \\
\hline & $\begin{array}{l}\text { Flow } \\
n^{3 / 4} \quad \text { is }\end{array}$ & $\begin{array}{r}\text { Radius } \\
n\end{array}$ & $\begin{array}{l}\text { Flow } \\
n^{3} / n \quad 1 / n\end{array}$ & $\begin{array}{c}\text { Rafius } \\
\text { n }\end{array}$ & $\begin{array}{l}\text { Flon } \\
m_{m}^{3} / \mathrm{n} \quad \mathrm{y}_{\mathrm{s}}\end{array}$ & $\begin{array}{c}\text { Rasus } \\
\mathrm{n}\end{array}$ & $\begin{array}{c}\text { Flow } \\
n^{3} / \mathrm{n} \quad y_{s}\end{array}$ & $\begin{array}{c}\text { Rafius } \\
n\end{array}$ & $\begin{array}{c}\text { Flow } \\
\mathrm{m}^{3 / \mathrm{m}} \quad \mathrm{V}_{\mathrm{s}}\end{array}$ & $\begin{array}{c}\text { Radies } \\
\mathrm{n}\end{array}$ & $\begin{array}{c}\text { Filow } \\
\mathrm{m}^{3 / 4} \quad V_{3}\end{array}$ & $\begin{array}{c}\text { Radis } \\
n\end{array}$ & $\begin{array}{c}\text { Filaw } \\
n^{3 / 1} \quad V_{3}\end{array}$ & $\begin{array}{r}\text { Radius } \\
n\end{array}$ \\
\hline 2,0 & & & $10,6 \quad 2,96$ & 26,0 & $13,9 \quad 3,86$ & 27,9 & $17,6 \quad 489$ & 29.7 & $217 \quad 6,04$ & 315 & $26,3 \quad 7,30$ & 33.1 & $31,3 \quad 8,69$ & 34,7 \\
\hline 2,5 & & & $119 \quad 3,31$ & 28,3 & $15,5 \quad 4,32$ & 30,4 & $19,7 \quad 5,47$ & 32,4 & $243 \quad 6,75$ & 343 & $29,4 \quad 8,17$ & 36,1 & $350 \quad 9,72$ & 37,8 \\
\hline 3,0 & $9,6 \quad 2,66$ & 27,9 & $13,0 \quad 3,62$ & 30,3 & $17,0 \quad 473$ & 32,6 & $216 \quad 5,99$ & 34,7 & $\begin{array}{ll}25,6 & 1,39\end{array}$ & 36,7 & $32,28,95$ & 38,7 & $\begin{array}{lll}38,3 & 10,65\end{array}$ & 40,5 \\
\hline 3,5 & \begin{tabular}{|ll}
10,4 & 2,87 \\
\end{tabular} & 29,5 & $141 \quad 3,91$ & 32,1 & $18,4 \quad 5,11$ & 345 & $\begin{array}{ll}23,3 & 6,47 \\
\end{array}$ & 36,8 & $\begin{array}{r}28,7 \\
\end{array}$ & 389 & $\begin{array}{ll}34,8 & 9,66 \\
\end{array}$ & 41,0 & $\begin{array}{lll}41,4 & 1150 \\
\end{array}$ & 43,0 \\
\hline 4,0 & 114.1 3,07 & 3,1 & $15.1 \quad 418$ & 33,8 & $19,7 \quad 5,46$ & 36,3 & $24.9 \quad 6.91$ & 38,7 & $30,7 \quad 8,54$ & 410 & $\begin{array}{lll}37.2 & 10,33\end{array}$ & 431 & $44,3 \quad 12,29$ & 45.2 \\
\hline 4,5 & $\begin{array}{ll}17 & 3,26 \\
\end{array}$ & 32,5 & $16,0 \quad 4,44$ & 35,3 & $20,9 \quad 5,80$ & 38,0 & $26,4 \quad 7,33$ & 40,5 & $32,6 \quad 9,05$ & 42,8 & $39,4 \quad 10,96$ & 451 & $46,9 \quad 13,04$ & 47,3 \\
\hline 5,0 & $12,4 \quad 3,44$ & 33,8 & $16,8 \quad 468$ & 36,8 & $22,0 \quad 6,11$ & 39,5 & $278 \quad 273$ & 42,1 & $34,4 \quad 9,54$ & 446 & $416 \quad 1155$ & 46,9 & $49,5 \quad 13,74$ & 49,2 \\
\hline 5,5 & $13,0 \quad 3,60$ & 35,1 & $1079 \quad 491$ & 38,1 & $23,1 \quad 6,41$ & 410 & $29,2 \quad 811$ & 43,7 & $36,0 \quad 10,01$ & 46,2 & $43,6 \quad 12,11$ & 48,7 & $\begin{array}{lll}51,9 & 14,42\end{array}$ & 510 \\
\hline 6,0 & \begin{tabular}{|ll}
13,6 & 3,76 \\
\end{tabular} & 36,3 & $18,4 \quad 5,12$ & 39,4 & $241 \quad 6,69$ & 42,4 & $\begin{array}{ll}30,5 & 8,47\end{array}$ & 45.1 & $37,6 \quad 10,46$ & 478 & $45,5 \quad 12,65$ & 50,3 & $542 \quad 15,06$ & 52,7 \\
\hline 6,5 & \begin{tabular}{|l|l|}
4,12 \\
\end{tabular} & 37,4 & $19,2 \quad 533$ & 40,6 & $25,1 \quad 6,96$ & 43,6 & $31,7 \quad 881$ & 465 & $39,2 \quad 10,88$ & 49,3 & $474 \quad 1317$ & 51,9 & $\begin{array}{lll}56,4 & 15,67 \\
\end{array}$ & 544 \\
\hline
\end{tabular}

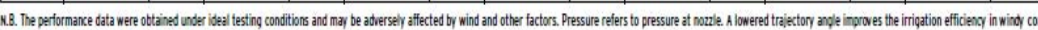

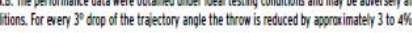

ECe VALUES FOR DIFFERENT CROPS THAT WILL
GIVE 10\% REDUCTION IN YIELD
\begin{tabular}{|c|lc|}
\hline S.No & Crop & Ece $(\mathrm{dS} / \mathrm{m})$ \\
\hline 1 & Cotton & 9.6 \\
2 & Sorghum & 5.1 \\
3 & Wheat & 7.4 \\
4 & Maize & 2.5 \\
\hline
\end{tabular}

The criteria for selection of sprinkler spacing are based on uniformity of water distribution within the limitation of wind velocity. Higher the wind velocity will result in lower spacing between the sprinklers and vice versa. Fig 6.5 below shows water distribution pattern of a particular sprinkler system. This depicts that area under the first $60 \%$ of the sprinkler's radius is generally sufficiently irrigated for growing crop without any overlapping. Beyond this, quantum of water will be reducing and thus will not be sufficient to grow crop. To overcome this problem, overlapping between the sprinklers is suggested with following recommendations. 


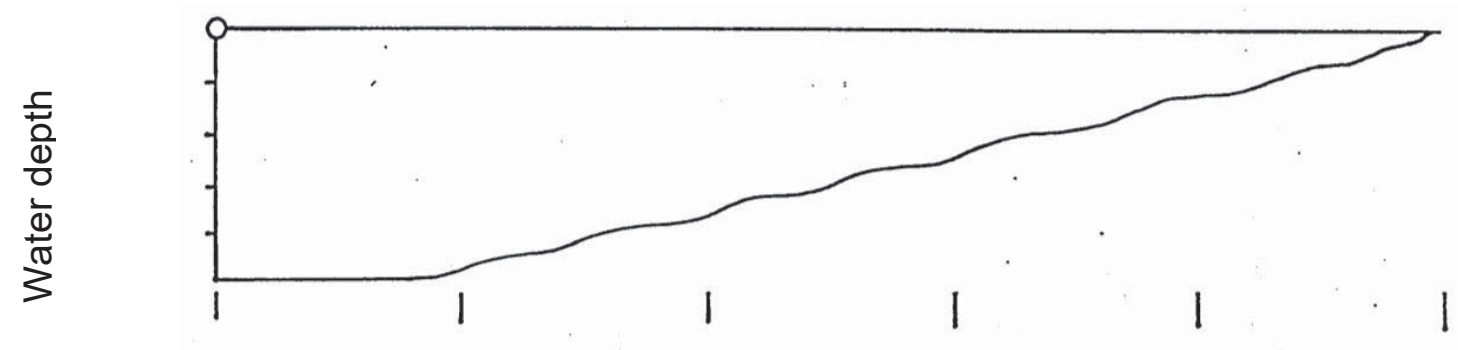

Distance from sprinkler

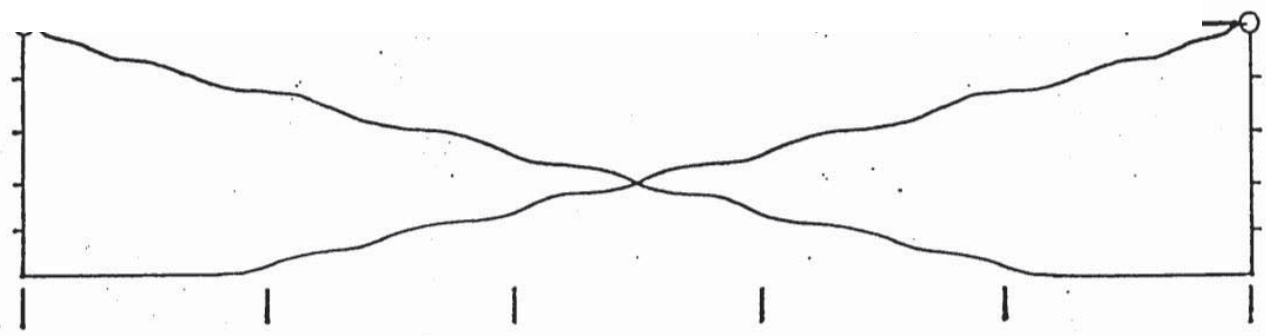

Fig. 6.5 Wetting Pattern Without and with Overlapping

At the same time wind badly affects the distribution pattern of a sprinkler system. Fig. 6.6 shows the effect of wind over the distribution pattern of a particular sprinkler system.

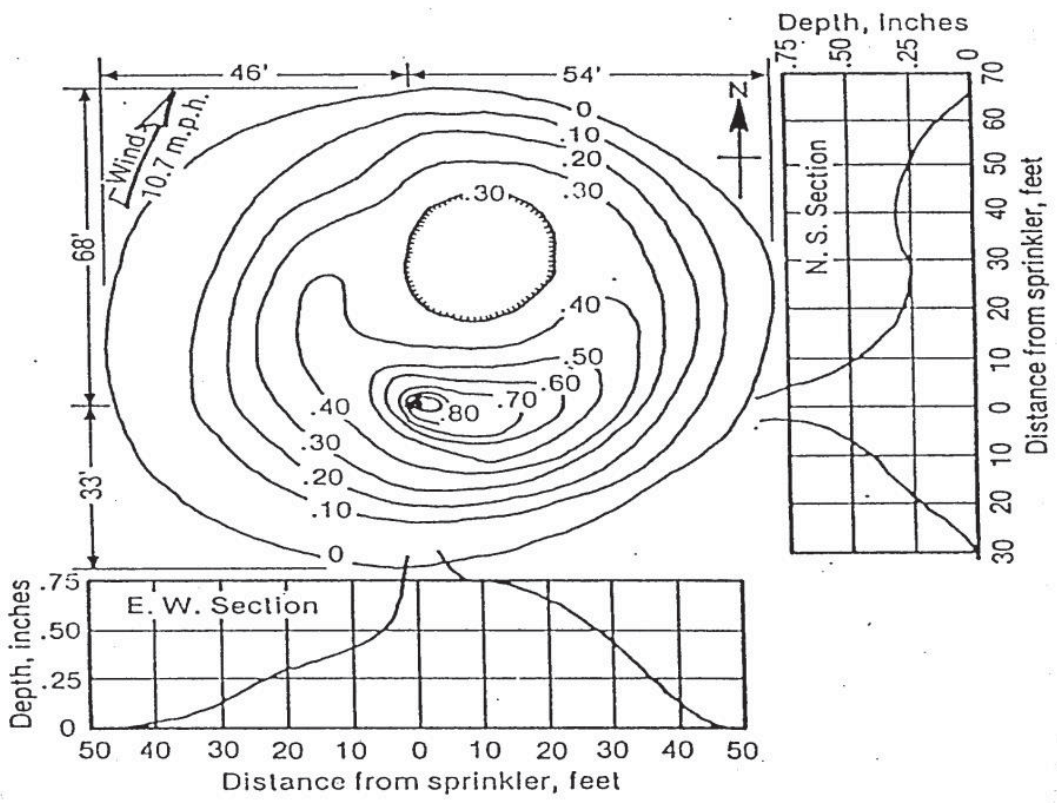

Fig 6.6 Distribution Pattern Distorted by Wind (10.7 MPH)

Volume of water delivered from the sprinkler varies from sprinkler to the edge of the wetted radius as shown in Fig. below. More water will be available near the sprinkler and will be reduced gradually as we move away from sprinkler. Finally, where the sprinkler radius came to an end there will be no water. Sprinkler water distribution graph is shown in Fig 6.7. 


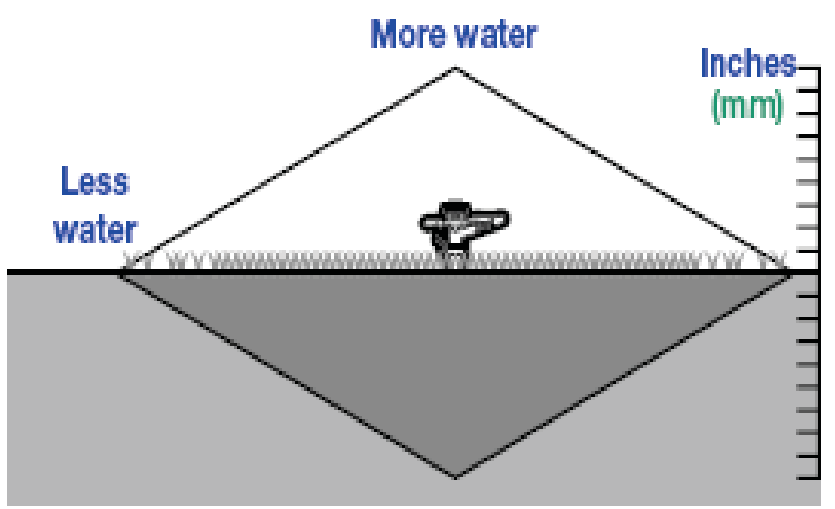

Fig 6.7 Sprinkler water distribution graph (Courtesy: Rain Bird)

It is noted that $60 \%$ radius of the sprinkler will be well irrigated to meet the crop water demands and remaining $40 \%$ will be under irrigated. To overcome this problem, the flow from other sprinkler should fall in this $40 \%$ radius of the first sprinkler so as sum of flows from both sprinklers in this area would approximately match the flow depth in the $60 \%$ radius of the first sprinkler as shown in the Fig 6.8 .

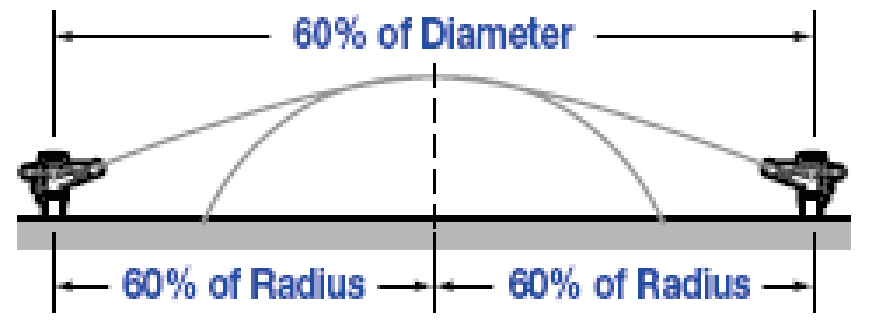

Fig $6.8 \quad 60 \%$ of diameter sprinkler spacing (Courtesy: Rain Bird)

Another layout showing head-to-head sprinkler spacing is shown in following Fig $\mathbf{4 . 9}$ to match the flow in each part of the area under sprinkler system.

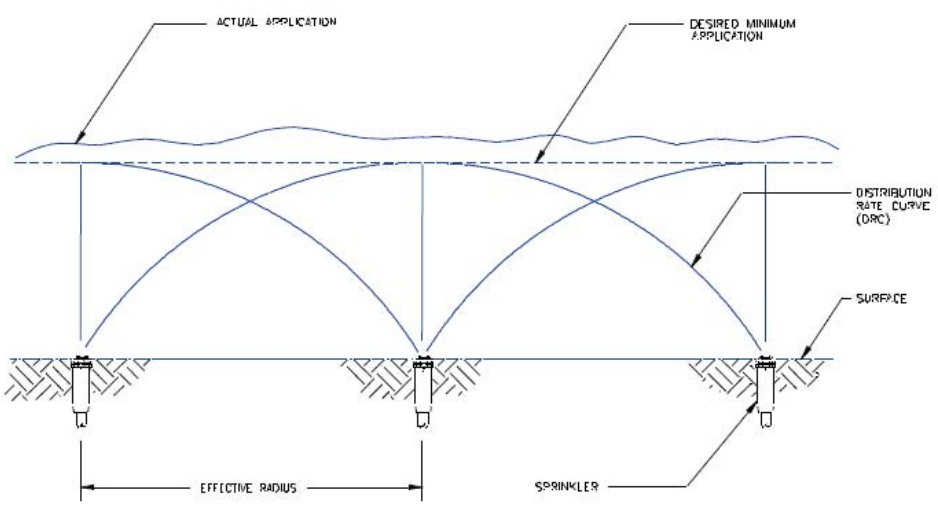

Fig 6.9 Head To Head Sprinkler Spacing For Uniform Water Distribution 


\subsubsection{Effect of pressure on Sprinkler}

Sprinkler wetting pattern is affected by pressure and nozzle size. For a particular combination of nozzle size and at manufacturer's recommended operating pressure, precipitation profile seems like Fig 6.10-b. When pressure is much lower than the manufacturer's recommended pressure, large sized drops fall near the sprinkler in a ring as shown in Fig. 6.10-a. When pressure is much higher than manufacturers recommended pressure, then very small sized drops results and can be distorted easily and precipitation profile results like Fig. 6.10-c.

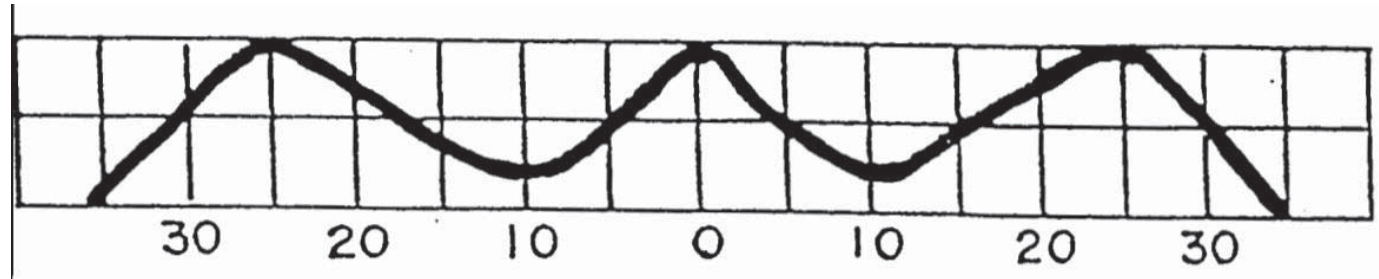

Fig 6.10-a. Pressure is too low

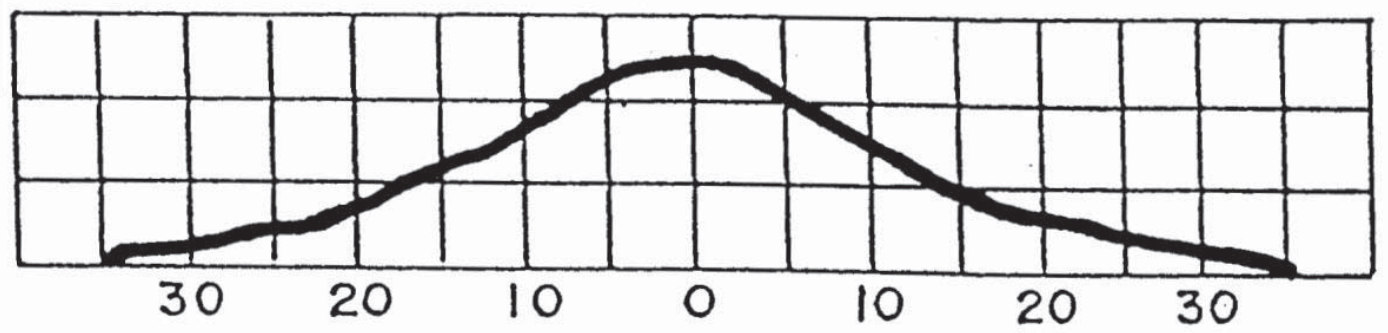

Fig 6.10-b. Pressure is satisfactory

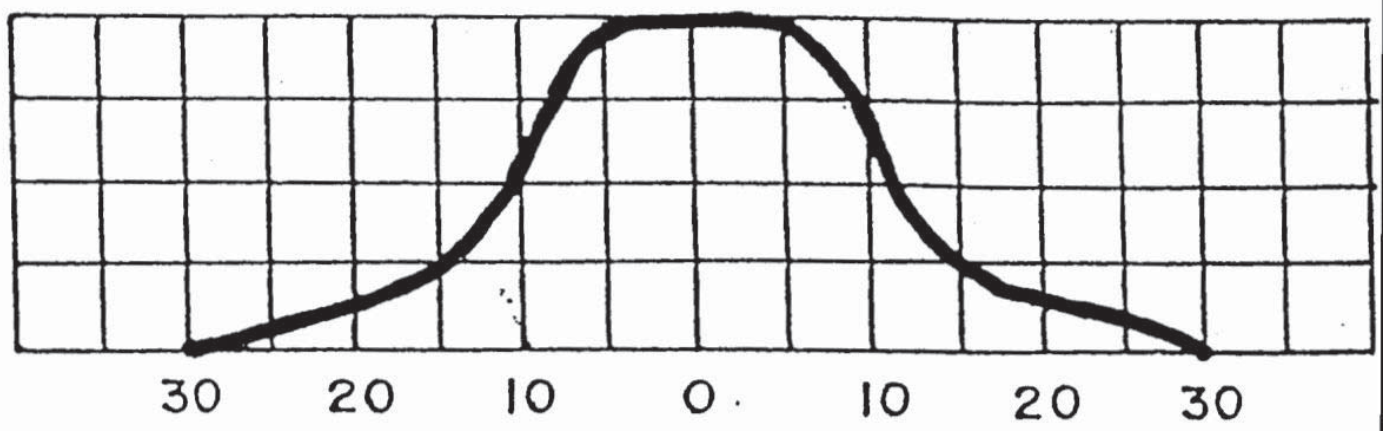

Fig 6.10-c. Pressure is too high

\subsubsection{Sprinkler Pattern}

There are three different ways for placing sprinklers to achieve uniform application of water namely square, triangle and rectangular pattern.

The detail of sprinkler patterns is explained in the following sections. 


\section{Square Spacing}

The distance between sprinkler along the laterals and between the lateral is kept same under square pattern of sprinkler spacing as shown in Fig.6.11. This pattern is suitable to sites which are square in geometry. The spacing between sprinklers is decided based on the wind conditions as given below:

- For wind velocity 0 to $3 \mathrm{mph}$ ( 0 to $5 \mathrm{~km} / \mathrm{h}$ ), the spacing should be $55 \%$ of diameter

- For wind velocity 4 to $7 \mathrm{mph}(6$ to $11 \mathrm{~km} / \mathrm{h})$, the spacing should be $50 \%$ of diameter

- For wind velocity 8 to $12 \mathrm{mph}$ (13 to $19 \mathrm{~km} / \mathrm{h}$ ), the spacing should be $45 \%$ of diameter
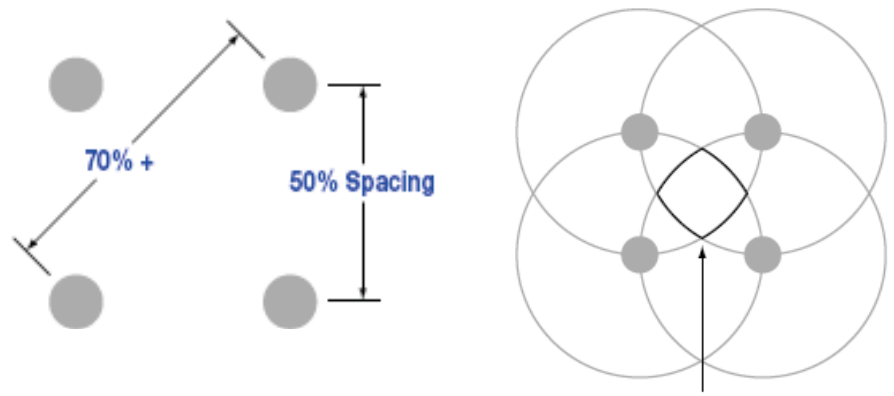

Fig 6.11 Square sprinkler pattern

The limitation of square pattern is that diagonal distance increases to approximately $70 \%$ of wetted diameter (for $50 \%$ sprinkler spacing).

\section{Triangular Spacing}

Triangular spacing is generally adopted for irregular field boundaries, over spray is permitted and no part circle sprinklers are needed. The geometrical view of triangular spacing is shown in Fig 6.12. The recommended spacing for this pattern as suggested by Rain Bird is given below:

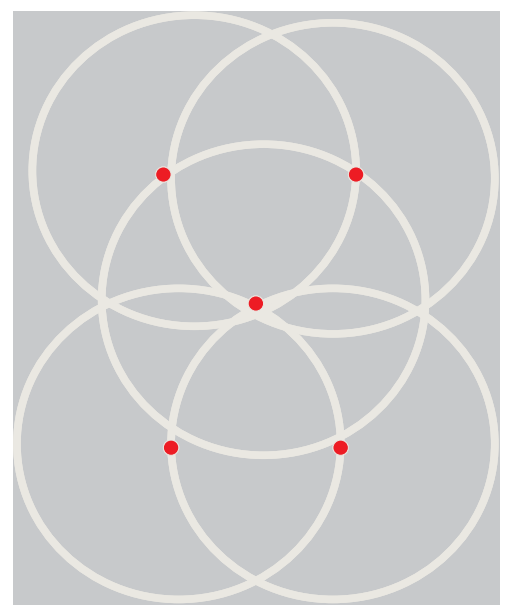

Fig 6.12

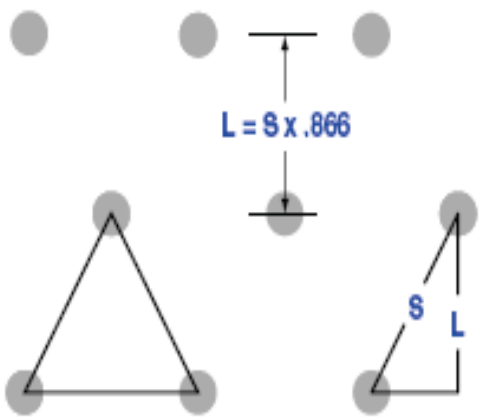

Triangular Sprinkler Pattern

The distance between sprinklers is usually labeled $\mathrm{S}$, and the distance between rows is labeled $\mathrm{L}$. 
Sprinkler spacing should be selected based on the following relationship.

$L=S \times 0.866$

Where:

$\mathrm{L} \quad=\quad$ sprinkler spacing between lateral

$\mathrm{S}=$ sprinkler spacing at lateral

Recommends triangular spacing (Source Rain Bird):

$60 \%$ if wind velocities are $0-3 \mathrm{mph}$ on site.

$55 \%$ if wind velocities are $4-7 \mathrm{mph}$ on site.

$50 \%$ if wind velocities are $8-12 \mathrm{mph}$ on site.

\section{Rectangular Spacing}

The spacing between lateral $(\mathrm{L})$ is usually kept more than the sprinkler spacing $(\mathrm{S})$ forming a rectangular pattern. The recommended spacing for rectangular pattern is given below.

Recommended triangular spacing (Source Rain Bird):

$\mathrm{L}=60 \%$ of wetted diameter, $\mathrm{S}=50 \%$ wetted diameter if wind velocities are $0-3 \mathrm{mph}$ on site.

$\mathrm{L}=60 \%$ of wetted diameter, $\mathrm{S}=45 \%$ wetted diameter if wind velocities are $4-7 \mathrm{mph}$ on site.

$\mathrm{L}=60 \%$ of wetted diameter, $\mathrm{S}=40 \%$ wetted diameter if wind velocities are $8-12 \mathrm{mph}$ on site.

\section{CONSUMPTIVE USE}

For the design of surface and sprinkler irrigation systems:

ETcrop $=$ ETo $\times$ Kc/(1-LR)

Potential Water Requirement $=\mathrm{ETcrop} /($ Efficiency $)$

\section{LEACHING REQUIREMENT}

$L R=\frac{E C w}{5(E C e)-E C w}$

$\mathrm{LR} \quad=\quad$ leaching requirement (Fraction)

$\mathrm{Ecw}=$ Salinity of applied irrigation water in $\mathrm{dS} / \mathrm{m}$

Ece $=$ Average soil salinity tolerated by crop taken from literature

\section{IRRIGATION DEPTH}

$\mathrm{dx} \quad \quad=\quad \operatorname{MAD}(\mathrm{Wa} \cdot \mathrm{Z}) / 100$

$\mathrm{dx} \quad=$ Maximum depth of water to be applied per irrigation $(\mathrm{mm})$ 


$\begin{array}{lll}\text { MAD } & =\text { Management Allowed Deficit (\%) } & \\ \text { Wa } & =\text { Water holding capacity of soil, } & \mathrm{mm} / \mathrm{m} \\ \mathrm{Z} & \text { =Effective root depth, } \mathrm{m} & \end{array}$

\section{IRRIGATION INTERVAL}

\begin{tabular}{|c|c|c|}
\hline $\mathrm{Fx}=\mathrm{dx} / \mathrm{Cu}$ & MAD (Wa . Z)/(cu . 100) & \\
\hline$F x$ & $=$ Irrigation interval, days & \\
\hline$d x$ & = Maximum depth of water to be & applied per irrigation ( $\mathrm{mm})$ \\
\hline MAD & =Management Allowed Deficit (\%) & \\
\hline Wa & $=$ Water holding capacity of soil, & $\mathrm{mm} / \mathrm{m}$ \\
\hline$Z$ & $=$ Effective root depth, $\mathrm{mm}$ & \\
\hline${ }_{1}$ & $=$ Consumptive use, $\mathrm{mm}$ & \\
\hline
\end{tabular}

\section{OPERTIONAL TIME}

Operation time depends upon various factors including;

- Weather conditions

- Crop stage,

- Root depth etc.

Daily operation time $=$

Daily consumptive use/ Application Rate

\section{SYSTEM HYDRAULICS}

- Determining the pressure distribution in the system

- Selection of pipe sizes and fittings to convey and regulate water delivery

- Determining the power and energy requirements

\section{WAYS OF CALCULATING FRICTION LOSS}

- Equations

- Hazen-Williams

- Darcy-Weisbach

- Watters and Keller

- Tables/Charts

- for any given pipe material, pipe diameter, and flow rate, look up values for friction loss in meter per hundred meters of pipe

- Software:

- Based on equations

\section{FACTORS AFFECTING FRICTION LOSS}

- Flow rate

- Pipe diameter

- Pipe length

- Pipe roughness

- Type of fluid 


\section{HAZEN- WILLIAM EQUATION}

$$
\begin{array}{ll}
\mathbf{J}=\mathbf{h f} /(\mathbf{L} / \mathbf{1 0 0})=\mathbf{K}(\mathbf{Q} / \mathbf{C})^{1.852 *} \mathbf{D}-4.87 \\
\mathrm{~J} & =\text { head loss gradient, } \mathrm{m} / 100 \mathrm{~m} \\
\mathrm{~K} & =\text { Conversion constant, } 1.212 * 10^{\wedge 12} \text { for metric units } \\
\mathrm{Hf} & =\text { Head loss due to pipe friction, } \mathrm{m} \\
\mathrm{L} & =\text { Length of pipe, } \mathrm{m} \\
\mathrm{Q} & =\text { Flow rate in pipe, L/S } \\
\mathrm{C} & =\text { Friction Factor, for PVC pipe C=150 } \\
\mathrm{D} & =\text { Inside diameter of pipe, } \mathrm{mm}
\end{array}
$$

Typical values of $\mathrm{C}$ for use in the Hazen-Williams equation are:

\begin{tabular}{lr} 
Pipe Material & C \\
\hline Plastic & 150 \\
Epoxy-coated steel & 145 \\
Cement asbestos & 140 \\
Galvanized steel & 135 \\
Aluminum (with couplers every 30 ft) & 130 \\
Steel (new) & 130 \\
Steel (15 years old) or concrete & 100 \\
\hline
\end{tabular}

Source: (Keller and Blisner, 1988, page 135)

For smooth plastic pipes, Watters and Keller (1978) proposed the following equations as discussed by Keller and Bliesner (1988, page 138):

\section{WATERS AND KELLER FORMULA}

$$
\begin{aligned}
& \text { For small Pipe less than } 125 \mathrm{~mm} \\
& \begin{array}{ll}
\mathbf{J}=100 & { }^{*} \mathbf{h f} / \mathbf{L}=\quad \mathbf{K}(\mathbf{Q})^{1.852} \times \mathbf{D}^{-4.75} \\
\mathrm{~J} & =\text { head loss gradient, } \mathrm{m} / 100 \mathrm{~m} \\
\mathrm{~K} & =\text { Conversion constant, } 7.89 * 10^{\wedge} 7 \text { for metric units } \\
\mathrm{Hf} & =\text { Head loss due to pipe friction, } \mathrm{m} \\
\mathrm{L} & =\text { Length of pipe, } \mathrm{m} \\
\mathrm{Q} & =\text { Flow rate in pipe, } \mathrm{L} / \mathrm{S} \\
\mathrm{D} & =\text { Inside diameter of pipe, } \mathrm{mm}
\end{array}
\end{aligned}
$$

\section{WATERS AND KELLER FORMULA}

$$
\begin{aligned}
& \text { For Pipe Greater than } 125 \mathrm{~mm} \\
& \begin{array}{ll}
\mathbf{J}=100 & { }^{*} \mathbf{h f} / \mathbf{L}=\quad \mathrm{K}(\mathbf{Q})^{1.83} / \mathbf{D}{ }^{4.83} \\
\mathrm{~J} & =\text { head loss gradient, } \mathrm{m} / 100 \mathrm{~m} \\
\mathrm{~K} & =\text { Conversion constant, } 9.58 * 10^{7} \text { for metric units } \\
\mathrm{Hf} & =\text { Head loss due to pipe friction, } \mathrm{m} \\
\mathrm{L} & =\text { Length of pipe in, } \mathrm{m} \\
\mathrm{Q} & =\text { Flow rate in pipe, } \mathrm{L} / \mathrm{S} \\
\mathrm{D} & =\text { Inside diameter of pipe }, \mathrm{mm}
\end{array}
\end{aligned}
$$




\section{DARCY- WEISBACH AND BLASIUS EQ.}

Darcy- Weisbach and Blasius Equation can be combined to give accurate prediction of friction head loss for smooth plastic pipes of less than $125 \mathrm{~mm}(5 \mathrm{in}$.) diameter.

$$
\begin{array}{ll}
\mathbf{J}=100 & \mathbf{h f} / \mathbf{L}=\mathbf{k}^{*}\left[\left(\mathbf{Q}^{1.75}\right) /\left(\mathbf{D}^{4.75}\right)\right] \\
\mathrm{J} & =\text { Head loss gradient, } \mathrm{m} / 100 \mathrm{~m} \\
\mathrm{Hf} & =\text { pipe friction head loss, } \mathrm{m} \\
\mathrm{K} & =\text { Constant, } 7.89 * 10^{\wedge} 7 \text { for metric units } \\
\mathrm{Q} & =\text { Flow Rate, LPS } \\
\mathrm{L} & =\text { Pipe length, } \mathrm{m} \\
\mathrm{D} & =\text { Inside Diameter of Pipe, } \mathrm{mm}
\end{array}
$$

\section{VELOCITY FORMULA TO DETERMINE PIPE SIZE FOR MAINLINE}

$v=1.274 q / d^{2}$

$d^{2}=V /(1.274 q)$

$d=\operatorname{SQRT}[V /(1.274 q)]$

$v=$ velocity $(\mathrm{m} / \mathrm{s})$

$q=$ volume flow $\left(\mathrm{m}^{3} / \mathrm{s}\right)$

$d=$ pipe inside diameter $(m)$

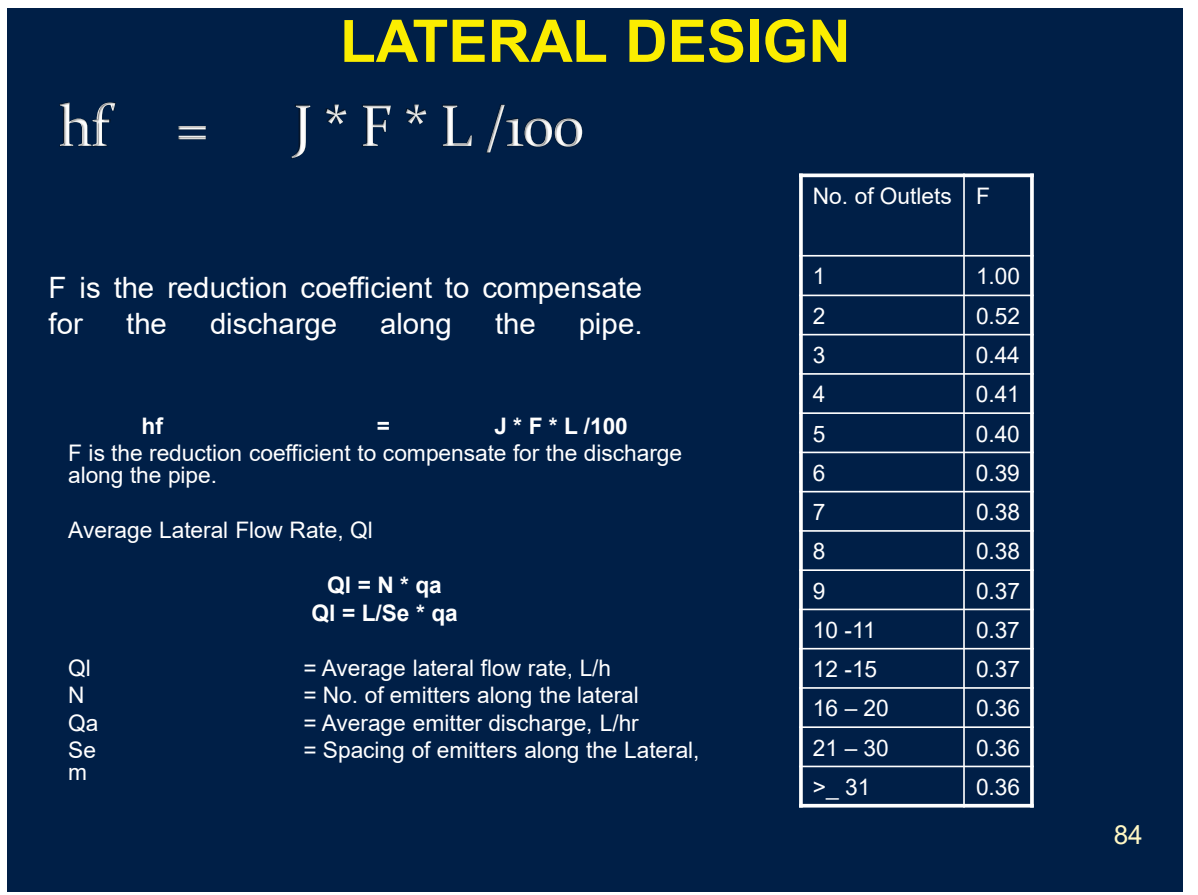

\section{MINOR LOSSES}

(Fittings and Valve Losses) 


$\begin{array}{lll}\mathrm{Hf} & = & \mathrm{Kr}\left[\mathrm{V}^{2} / 2 \mathrm{~g}\right] \\ \mathrm{Hf} & = & \text { Friction head loss due to pipe fittings, } \mathrm{m}(\mathrm{ft}) \\ \mathrm{Kr} & = & \text { Resistance coefficient for the fitting or valve } \\ \mathrm{V} 2 / 2 \mathrm{~g}= & \text { Velocity head for given discharge, } \mathrm{m}(\mathrm{ft}) \\ \mathrm{g} & = & \text { Acceleration due to gravity, } 9.81 \mathrm{~m} / \mathrm{s}(32.2 \mathrm{ft} / \mathrm{sec}) \\ \mathbf{V}^{2} / \mathbf{2 g}= & \mathrm{KQ}^{2} / \mathbf{D}^{4}\end{array}$

$\mathrm{K}$ is constant $8.26 \times 10^{4}$ for metric unit, $2.59 \times 10^{-3}$ for English unit)

Table 8.4. Resistance coefficient $\mathrm{K}$ for use determining head losses in fittings and valves.

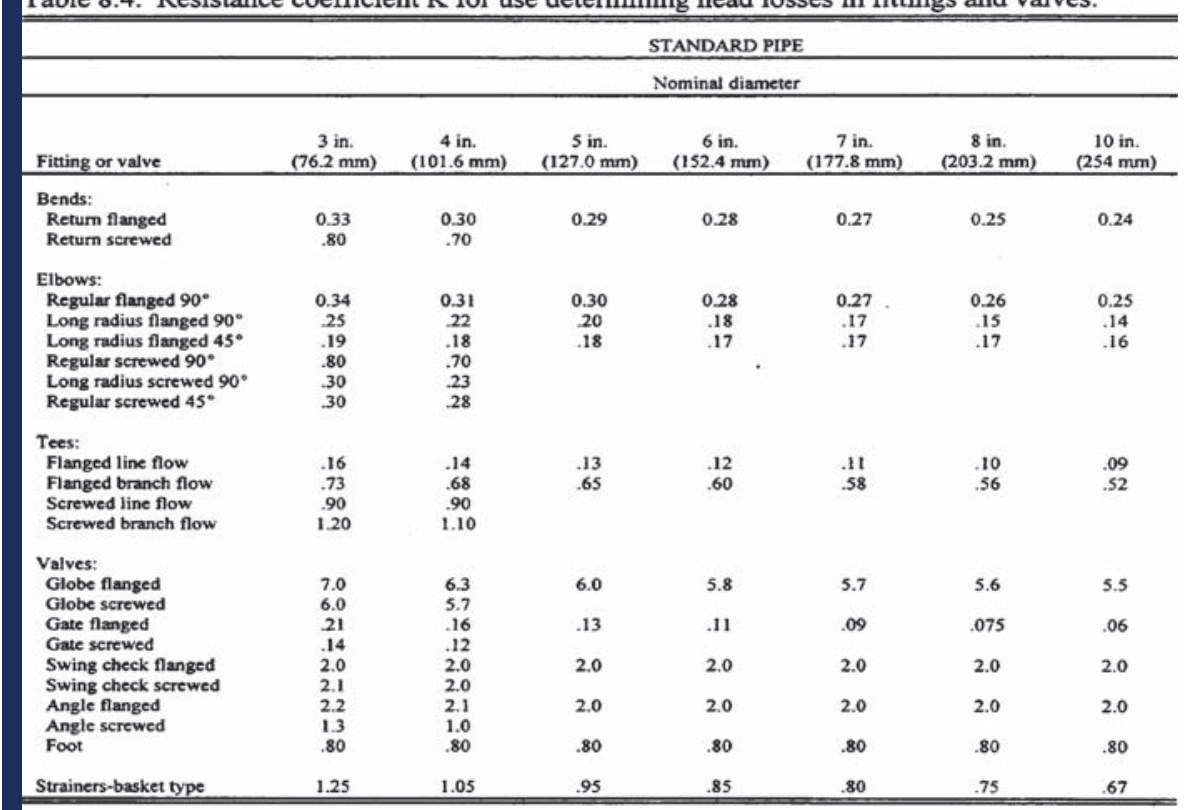

-SCS National Engineering Handbook, Section 15, Chapter 11

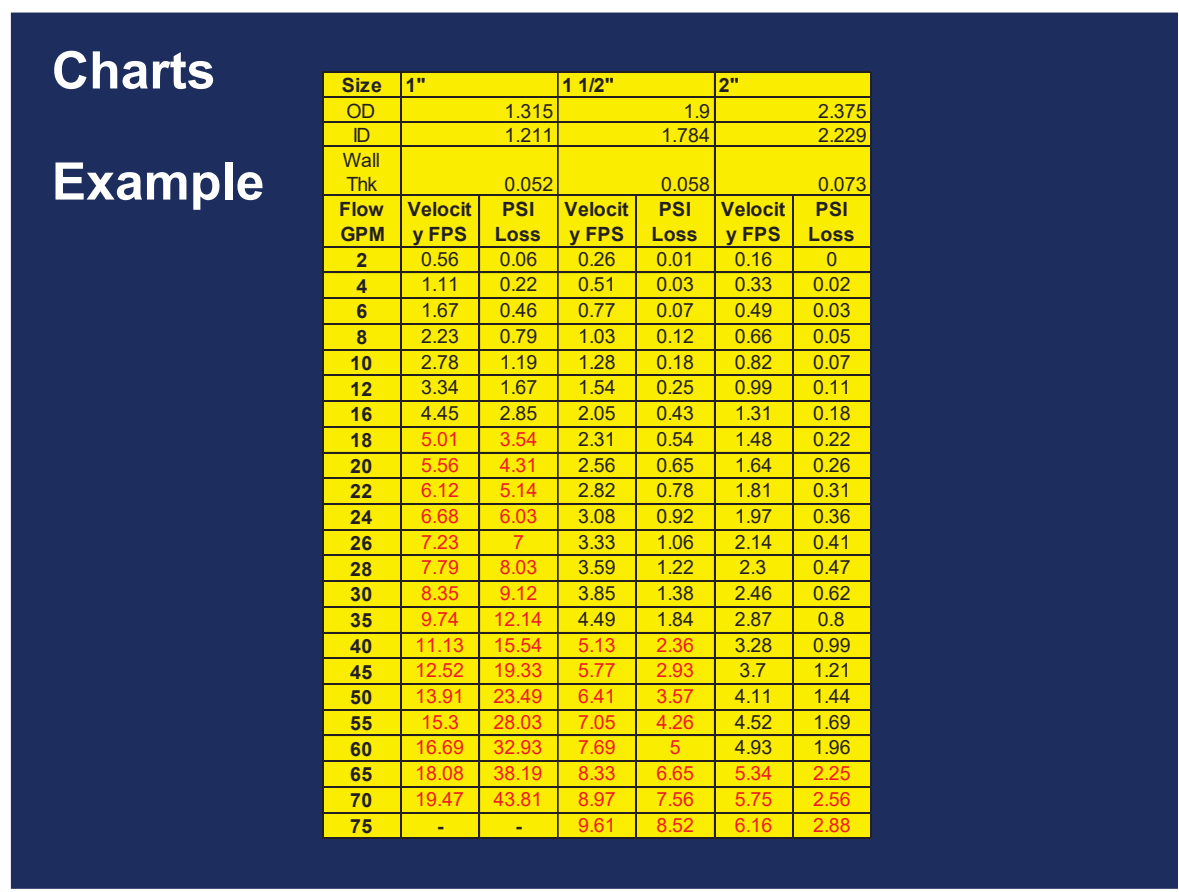




\section{Total head required $(\mathrm{H})$}

Total dynamic head should be capable of supplying required pressure and discharge for efficient functioning of the system.

Total head required $(\mathbf{H})=$ suction head + Delivery head + Filtration losses + Fertigation system losses+ Friction loss in pipes (main, sub-main and lateral) + Emitter operating pressure+ Fitting losses + Elevation (if any)

Suction

Delivery

Filtration losses

Fertigation losses
$=$ Vertical distance between water level to center of pump

$=$ Vertical distance between center of pump to ground level

$=$ Filtration head losses in different types of filters

$=$ Certain pressure is required to operate fertigation

system, generally $5 \mathrm{~m}$ for manually operated ventury.

Friction losses in pipe $=$ sum of pressure loss calculated for main, sub-main and lateral lines Emitter operating pressure $=$ Recommended emitter operating pressure given by the manufacturer

Fitting Losses = Generally $20 \%$ of pipe network lossess

Elevation $\quad=$ Vertical distance b/w ground level near to water source

to the highest or lowest level

HORSE POWER REQUIRED

$H . P=\frac{Q \times H}{75 \times \mathrm{e} 1 \times \mathrm{e} 2}$

where:

$Q$ is discharge, $1 / \mathrm{s}$

$\mathrm{H}$ is the total head, $\mathrm{m}$;

$\mathrm{e} 1$ is the pump efficiency (fraction in the order of $0.5-0.8$ ); and

$\mathrm{e} 2$ is the driving efficiency (fraction of 0.7-0.9 for electric motors and

0.5-0.75 for diesel engines).

The overall pumping efficiency under field conditions ranges accordingly from 0.35 in engine driven units to 0.50 in motor driven pumps. Higher efficiencies are not realistic. (Always rely on manufacturer chart to know the actual horse power)

\subsection{Design Process Sprinkler}

\subsubsection{Factors Affecting the Layout of Sprinkler System}

- Availability of water, quality, and source of power

- Soil factors

- Crop factors and uniformity required

- Purpose of the system and amount and frequency of water application 
- Sprinkler spacing, nozzle size, and operating pressure

- Relative land elevations and pressure requirements.

- Layout of main and lateral lines

- Sizing of main and lateral lines for proper operation.

- Plans for proper operation of system

- Economic analysis

\subsubsection{Design Procedure-Step by Step (Sprinkler)}

Under the on-going project, sprinkler systems are being installed on field crops. In this section, steps for designing a sprinkler irrigation system will be discussed. The following are the design steps.

- Collection of Basic Information

- Selection of Sprinkler Heads

- Place sprinkler heads

- Design map

- Calculation of total flow

- Estimation of PWR

- Calculation of Application rate

- Running time per operation

- No. of operations

- Calculation of sectional flow

- Calculation of total dynamic head $(\mathrm{H})$

- Calculation of required horsepower (HP)

- Selection of Pumps and Motor

- Preparation of Drawing

- Preparation of Bill of Quantities

Step 1. Collection of Basic Information

The following basic information be available before designing a sprinkler irrigation system.

- General information: Name of farmer, village/chak No., tehsil, district, phone No.

- Land holding and Area of the project

- Engineering survey: GPS coordinates, Field measurement, Elevation difference/slope. After field measurement, a map showing all dimensions and location of water source be drawn

- Agricultural details: crops (orchard, row/field crop), spacing, type, age, Effective Crop Root Depth, Reference Evapo-transpiration of the area (ETo), and water requirement of crop, Management Allowable Deficit (MAD)

- Crop Spacing (Row to Row, Plant to Plant), sowing and harvesting date

- Soil Type/texture, Water Holding Capacity

- Soil and water analysis reports: water quality, presence of iron, $\mathrm{pH}$, suspended particles, soil type, Electrical Conductivity of Irrigation water (Eciw), $\mathrm{pH}$

- Water Source, quantity, availability, location

- Power Source:Electric motor, diesel engine, tractor, solar system

- Climatologically data: temperature, humidity, rainfall, wind speed

- Peak Water Requirement: (ETo, Kc, Cf)

- Water source and Total Available Time of water

- System capacity: The system should have capacity adequate to fulfill daily crop water requirements of the area within a stipulated time or not more than 12 hours of operation per day (only for Pakistan circumferences, otherwise may be $22 \mathrm{hrs}$ ).

The basic information can be categorized as under. 


\section{GENERAL INFORMATION}

\begin{tabular}{|l|l|l|l|}
\hline Name of beneficiary & Town/Village/City & \\
\hline Tehsil & & District & \\
\hline Province & & Phone No. & \\
\hline Land holding (Acre) & & Scheme area (acres) & 16.06 \\
\hline Topography (Flat/Undulated) & & & \\
\hline
\end{tabular}

\section{CROP INFORMATION}

\begin{tabular}{|c|c|c|c|c|c|c|c|c|c|}
\hline \multicolumn{3}{|c|}{ Parameters } & \multirow{2}{*}{$\begin{array}{l}\text { Crop } \\
\text { Citrus }\end{array}$} & \multirow{2}{*}{$\begin{array}{c}\begin{array}{c}\text { Area } \\
\text { (acres) }\end{array} \\
7.04\end{array}$} & \multirow{2}{*}{$\begin{array}{c}\begin{array}{c}\text { Plant } \\
\text { spacig } \\
\text { (m) }\end{array} \\
3.10\end{array}$} & \multirow{2}{*}{$\begin{array}{c}\begin{array}{c}\text { Row } \\
\text { spacing } \\
(\mathrm{m})\end{array} \\
6.1\end{array}$} & \multirow{2}{*}{$\begin{array}{c}\begin{array}{c}\text { Age of } \\
\text { crop(years) }\end{array} \\
2\end{array}$} & \multirow{2}{*}{$\begin{array}{c}\text { Sowing } \\
\text { date }\end{array}$} & \multirow{2}{*}{$\begin{array}{c}\text { Harvesting } \\
\text { date }\end{array}$} \\
\hline \multirow[b]{2}{*}{ Block-I } & \multirow[t]{2}{*}{ Orchard } & Proposed & & & & & & & \\
\hline & & Rotation & & & & & & & \\
\hline \multicolumn{10}{|c|}{ Sub total: I } \\
\hline \multirow[b]{2}{*}{ Block-I } & \multirow[t]{2}{*}{ Orchard } & Proposed & Citrus & 6.07 & 4.57 & 4.57 & New & & \\
\hline & & Rotation & & & & & & & \\
\hline \multicolumn{10}{|c|}{ Sub total: II } \\
\hline \multirow[b]{2}{*}{ Block-I } & \multirow[t]{2}{*}{ Orchard } & Proposed & Mango & 1.2 & 6.10 & 6.1 & 1 & & \\
\hline & & Rotation & & & & & & & \\
\hline \multicolumn{3}{|c|}{ Sub total: III } & & & & & & & \\
\hline \multirow{3}{*}{ Block-I } & & & & & & & & & \\
\hline & & & & & & & & & \\
\hline & \multicolumn{2}{|c|}{ Sub total: IV } & & & & & & & \\
\hline
\end{tabular}




\section{SOIL TYPE/SOIL TEST/WATER SUPPY/WATER QUALITY}

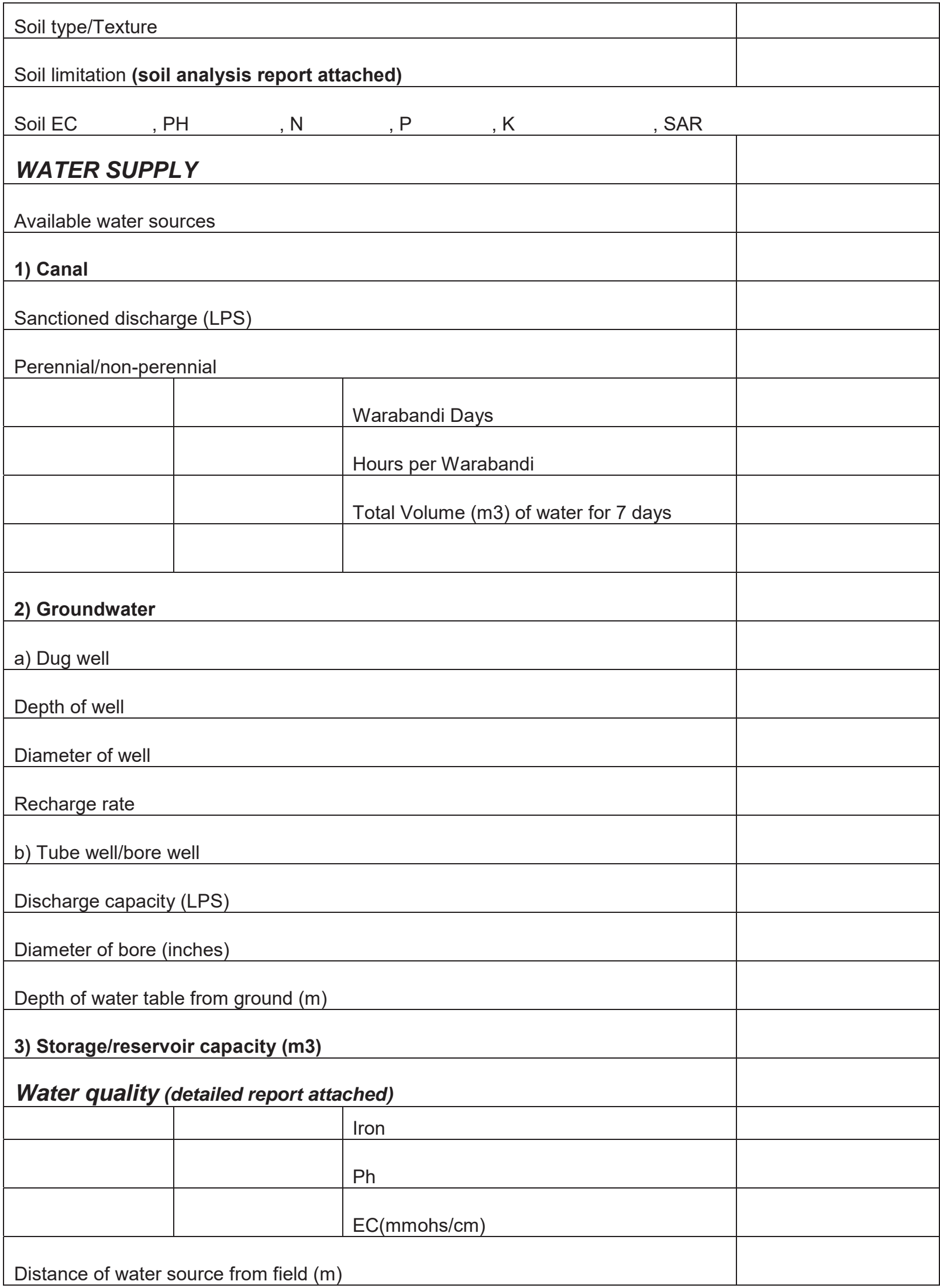




\section{POWER SOURCE AND PUMP}

\section{POWER SOURCE}

Type of power to be used

For electric Motor,

Type of connection (single/3-phase)

Make/model

HP of Motor

RPM of Motor

\section{For diesel engine}

Make

HP

Condition)

For Tractor

Make/model

HP

Condition

Any other power source, if any

PUMP SET

Type

Make/Model

Pressure (ft/psi/bar)

Flow(Ips)

Inlet/outlet size

RPM

Pulley size 


\section{Water Analysis Report}

\begin{tabular}{|l|l|}
\hline Farmer Name $\quad$ : Abbass Qureshi \\
\hline Address $\quad$ Muzaffar garh \\
\hline Ph :0345-8644888 \\
\hline Agronomist: Ather Mehmood Khursheed \\
\hline
\end{tabular}

\begin{tabular}{|l|l|}
\hline Water Source & \\
\hline Sampling Date & \\
\hline Sp Receive Date : & \\
\hline Report Date : & \\
\hline Ref.Sample \\
\hline
\end{tabular}

\begin{tabular}{|l|c|c|c|c|}
\hline \multirow{2}{*}{ Parameters } & \multicolumn{3}{|c|}{ Degree of Presence / Problem } \\
\cline { 2 - 5 } & Unit & Nomal & Higher & Extreme \\
\hline $\mathrm{pH}$ & & 7 & $<7$ Acidic & $>7 \mathrm{~A}$ \\
\hline Electrical Conductivity \\
\begin{tabular}{|l} 
(Salinity) \\
Total dissolved solids
\end{tabular} & microsemens/cm & - & - & - \\
\hline Hardness & $\mathrm{ppm}$ & $<500$ & $500-600$ & $>600$ \\
\hline Calcium & $\mathrm{ppm}$ & $<200$ & $200-300$ & $>300$ \\
\hline Magnesium & $\mathrm{ppm}$ & $<60$ & $60-100$ & $>100$ \\
\hline Carbonate & $\mathrm{Ppm}$ & $<25$ & $25-40$ & $>40$ \\
\hline Bicarbonate & $\mathrm{Ppm}$ & $<200$ & $200-600$ & $>600$ \\
\hline Chloride (Toxic) & $\mathrm{Ppm}$ & $<200$ & $200-600$ & $>600$ \\
\hline Sulphates & $\mathrm{Ppm}$ & $<140$ & $140-350$ & $>350$ \\
\hline Sodium & $\mathrm{Ppm}$ & $<20$ & $20-50$ & $>50$ \\
\hline SAR & $\mathrm{Ppm}$ & $<100$ & $100-200$ & $>200$ \\
\hline Potassium & - & $<3$ & $3-9$ & $>9$ \\
\hline Sulphides & $\mathrm{Ppm}$ & $<10$ & $10-20$ & $>20$ \\
\hline Iron & $\mathrm{Ppm}$ & $<15$ & $15-25$ & $>25$ \\
\hline Manganese & $\mathrm{Ppm}$ & $<0.1$ & $0.1-0.4$ & $>0.4$ \\
\hline Suspended solids & $\mathrm{Ppm}$ & $<0.2$ & $0.2-0.4$ & $>0.4$ \\
\hline Boron & $\mathrm{Ppm}$ & $<10$ & $10-100$ & $>100$ \\
\hline
\end{tabular}




\section{Soil Analysis Report}

\begin{tabular}{|c|c|c|c|c|c|c|c|c|c|c|c|}
\hline \multicolumn{2}{|c|}{ Farmer Name : } & \multicolumn{2}{|c|}{ Abbas Qureshi } & & & \multicolumn{2}{|l|}{ Block Size } & & & & \\
\hline Address & $:$ & \multicolumn{2}{|c|}{ Muzaffargarh } & & & \multicolumn{2}{|c|}{ Sampling Date : } & \multicolumn{2}{|l|}{$11 / 5 / 2010$} & & \\
\hline $\mathrm{Ph}$ & : & 34586448 & & & & Sp Receive D & e : & $13 / 05 / 2010$ & & & \\
\hline \multicolumn{2}{|c|}{ Agronomist : } & \multicolumn{2}{|c|}{ Ather Mehmood Sheikh } & & & Report Date & $:$ & \multicolumn{2}{|l|}{$26 / 04 / 2010$} & & \\
\hline & & & & & & Code & & AMK-S001 & & & \\
\hline \multirow[b]{2}{*}{$\begin{array}{c}\text { Ref.Soil } \\
\text { Sample } \\
\#\end{array}$} & \multirow[b]{2}{*}{$\begin{array}{c}\text { Block } \\
\#\end{array}$} & \multirow[b]{2}{*}{$\begin{array}{c}\text { Depth } \\
\text { (inches) }\end{array}$} & \multirow[b]{2}{*}{ Texture } & \multirow[b]{2}{*}{$\begin{array}{c}\text { Organic } \\
\text { Matter } \\
\%\end{array}$} & $\mathrm{pH}$ & $\begin{array}{c}\text { Electrical } \\
\text { conductivity } \\
(\mathrm{mic} / \mathrm{cm})\end{array}$ & $\begin{array}{c}\text { Available } \\
\text { Phosphorus(P) } \\
\text { (ppm) }\end{array}$ & $\begin{array}{c}\text { Available } \\
\text { Potassium(K) } \\
(\mathrm{ppm})\end{array}$ & \multirow{2}{*}{$\begin{array}{l}\text { Soluble } \\
\text { \& Exch. } \\
\qquad \mathrm{Na} \\
\text { (meq/L) }\end{array}$} & \multirow{2}{*}{$\begin{array}{c}\text { Soluble } \\
\text { \& Ca } \\
+\mathrm{Mg} \\
\text { (meq/L) }\end{array}$} & SAR \\
\hline & & & & & $\begin{array}{c}\text { Neutral } \\
6.5-7.5 \\
\text { Alkaline } \\
>8.5\end{array}$ & & $\begin{array}{c}\text { Poor }<7.0 \\
\text { Medium } 7-13 \\
\text { Satisfactorty }>13\end{array}$ & $\begin{array}{c}\text { Poor }<125 \\
\text { Medium 125- } \\
250 \\
\text { Satisfactorty } \\
>250\end{array}$ & & & $\begin{array}{c}\text { Normal } \\
<10.0 \text { Sodic } \\
>10.0\end{array}$ \\
\hline 2835 & \multirow{2}{*}{1} & $0-6^{\prime \prime}$ & Sand,Clay & 0.245 & 8.44 & 411 & - & 110 & 6.52 & 3.2 & 4 \\
\hline 2836 & & $6-12 "$ & Sand,Clay & 0.582 & 7.74 & 468 & - & 120 & 6.95 & 3.2 & 4.3 \\
\hline 2837 & \multirow{2}{*}{2} & $0-6^{\prime \prime}$ & Sand,Clay & 0.827 & 8.15 & 572 & - & 110 & 11.73 & 3.1 & 7.5 \\
\hline 2838 & & $6-12 "$ & Sand,Clay & 0.612 & 8.26 & 550 & - & 110 & 10.43 & 2.7 & 7.7 \\
\hline 2839 & \multirow{2}{*}{3} & $0-6^{\prime \prime}$ & Sand,Clay & 0.612 & 8.29 & 316 & - & 90 & 6.52 & 3.4 & 3.8 \\
\hline 2840 & & $6-12 "$ & Sand,Clay & 0.735 & 8.39 & 304 & - & 90 & 6.95 & 3.7 & 3.7 \\
\hline 2841 & \multirow{2}{*}{4} & $0-6^{\prime \prime}$ & Sand,Clay & 0.821 & 8.21 & 384 & - & 100 & 6.08 & 3.2 & 3.8 \\
\hline 2842 & & $6-12 "$ & Sand,Clay & 0.735 & 8.25 & 358 & - & 100 & 6.52 & 3.2 & 4 \\
\hline 2843 & & $0-6^{\prime \prime}$ & Sand,Clay & 1.01 & 8.02 & 506 & - & 150 & 4.34 & 5.1 & 1.7 \\
\hline 2844 & & $6-12 "$ & Sand,Clay & 0.98 & 8.02 & 494 & - & 160 & 4.34 & 4.2 & 2 \\
\hline 2845 & \multirow{2}{*}{6} & $0-6^{\prime \prime}$ & Sand,Clay & 1.041 & 8.05 & 412 & - & 120 & 4.34 & 4.2 & 2 \\
\hline 2846 & & $6-12 "$ & Sand,Clay & 0.919 & 8.11 & 356 & - & 100 & 4.34 & 4.2 & 2 \\
\hline 2847 & \multirow{2}{*}{7} & $0-6^{\prime \prime}$ & Sand,Clay & 0.919 & 7.97 & 1080 & - & 80 & 10.86 & 6.6 & 3.2 \\
\hline 2848 & & $6-12 "$ & Sand,Clay & 0.549 & 8.02 & 1123 & - & 80 & 11.73 & 5.8 & 4 \\
\hline
\end{tabular}

It is advisable to make rough map of the area and mark salient features, divide the drawn map into different blocks and number the same for soil and water sampling. This map will be finalized during designing of drip irrigation system and will show all necessary details including drippers, dia, length and location of laterals, submain and main, location of water source, power source etc., 


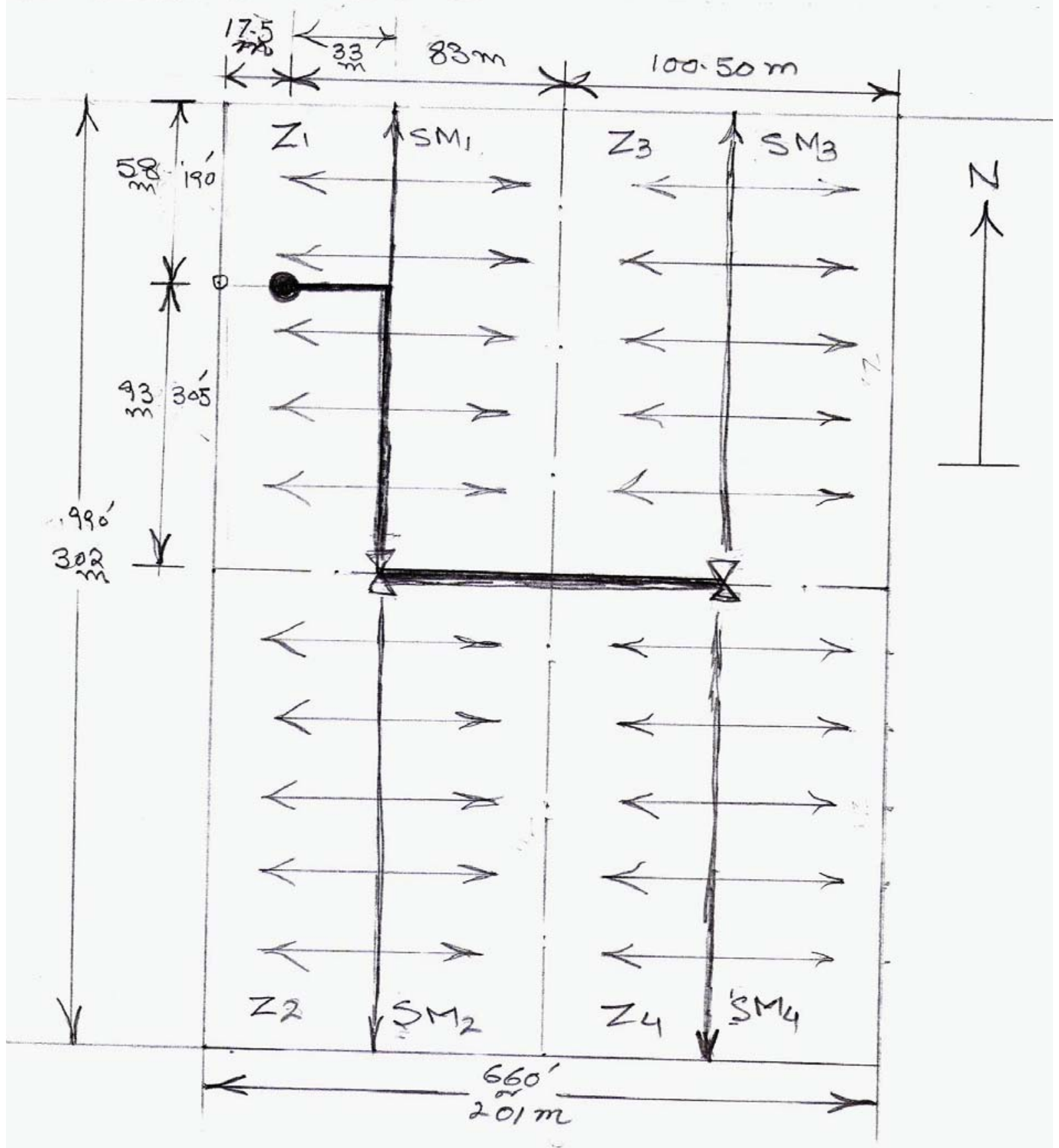

\section{Step 2. Estimation of Leaching Requirement}

All irrigation water contains some dissolved salts that are pushed downward by sprinkling and rainfall. By applying more water than the plants consume, most of the salts can be pushed or leached below the root zone. The first step in computing bye additional water required for leaching is to determine the leaching requirement by:

$$
L R=\frac{E C_{w}}{5 E C_{e}-E C_{w}}
$$


Where

$\mathrm{LR} \quad$ = leaching requirement ratio for sprinkle or surface irrigation

$\mathrm{EC}_{\mathrm{w}}=$ electrical conductivity of the irrigation water, Ds/M (MMHOS/CM)

$\mathrm{EC}_{\mathrm{e}}=$ estimated electrical conductivity of the average saturation extract of the soil root zone profile for an appropriate yield reduction, $\mathrm{ds} / \mathrm{m}(\mathrm{mmhos} / \mathrm{cm})$

It is recommended that the $\mathrm{EC}_{\mathrm{e}}$ values presented in Table 3.5 be used in Eq. 3.3. These are values that will give an approximate $10 \%$ yield reduction, as

Table 3.5. Values of $E C_{\mathrm{e}}$ that will give $10 \%$ yield reduction for various crops ${ }^{1}$

\begin{tabular}{|c|c|c|c|}
\hline Crop & $E C_{e}-\mathrm{dS} / \mathrm{m}$ & Crop & $E C_{e}-\mathrm{dS} / \mathrm{m}$ \\
\hline \multicolumn{4}{|l|}{ Field crops } \\
\hline Barley & 10.0 & Rice & 3.8 \\
\hline Cotton & 9.6 & Corn & 2.5 \\
\hline Sugar beets & 8.7 & Flax & 2.5 \\
\hline Wheat & 7.4 & Broadbeans & 2.6 \\
\hline Soybean & 5.5 & Cowpeas & 2.2 \\
\hline Sorghum & 5.1 & Beans & 1.5 \\
\hline Groundnut & 3.5 & & \\
\hline \multicolumn{4}{|l|}{ Fruit and nut crops } \\
\hline Date palm & 6.8 & Apricot & 2.0 \\
\hline Fig, olive & 3.8 & Grape & 2.5 \\
\hline Pomegranate & 3.8 & Almond & 2.0 \\
\hline Grapefruit & 2.4 & Plum & 2.1 \\
\hline Orange & 2.3 & Blackberry & 2.0 \\
\hline Lemon & 2.3 & Boysenberry & 2.0 \\
\hline Apple, pear & 2.3 & Avocado & 1.8 \\
\hline Walnut & 2.3 & Raspberry & 1.4 \\
\hline Peach & 2.2 & Strawberry & 1.3 \\
\hline \multicolumn{4}{|l|}{ Vegetable crops } \\
\hline Beets & 5.1 & Sweet corn & 2.5 \\
\hline Broccoli & 3.9 & Sweet potato & 2.4 \\
\hline Tomato & 3.5 & Pepper & 2.2 \\
\hline Cucumber & 3.3 & Lettuce & 2.1 \\
\hline Cantaloupe & 3.6 & Radish & 2.0 \\
\hline Spinach & 3.3 & Onion & 1.8 \\
\hline Cabbage & 2.8 & Carrot & 1.7 \\
\hline Potato & 2.5 & Beans & 1.5 \\
\hline \multicolumn{4}{|l|}{ Forage crops } \\
\hline Tall wheat grass & 9.9 & Wild rye grass & 4.4 \\
\hline Bermuda grass & 8.5 & Vetch & 3.9 \\
\hline Barley (hay) & 7.4 & Alfalfa & 3.4 \\
\hline Rye grass & 6.9 & Corn (forage) & 3.2 \\
\hline Crested wheat grass & 6.0 & Berseem clover & 3.2 \\
\hline Tall fescue & 5.8 & Orchard grass & 3.1 \\
\hline Sudan grass & 5.1 & Clover & 2.3 \\
\hline
\end{tabular}

'Adapted from Ayers and Westcott (1985). 
presented by Ayers and Westcott (1985). (For conversion purposes: 1.0 ppm $\simeq 640 \times E C$ in $\mathrm{dS} / \mathrm{cm}$.)

Under full irrigation, where $L R<0.1$, the annual deep percolation losses, even in most of the least watered areas, will normally be sufficient to provide the necessary leaching. However, under deficit irrigation or when $L R \geqslant 0.1$, water in addition to the consumptive use should be applied or available at some time during the year to satisfy leaching requirements. The ratio of the total depth of irrigation water required with and without leaching is equal to $1 /(1$ $-\boldsymbol{L R})$.

\section{Sample Calculation 3.3 Computing leaching requirement for a sprinkle irrigation system.}

GIVEN: Corn irrigated by a traveling sprinkler with water having an electrical conductivity of $E C_{w}=2.1 \mathrm{dS} / \mathrm{m}$.

FIND: The leaching requirement.

CALCUlations: From Table 3.5, the electrical conductivity of the average saturation extract of the soil root zone profile that would give a $10 \%$ yield reduction, $E C_{e}=2.5 \mathrm{dS} / \mathrm{m}$, and by Eq. 3.3:

$$
L R=\frac{2.1}{5(2.5)-2.1}=0.20
$$

\section{Step 2. Estimation of Peak Crop Water}

Requirement

Estimating the reference crop evapo-transpiration (ETo), using the Penman-Monteith method, and the crop evapo-transpiration (ETc), through the use of the appropriate crop factor Kc, have been covered in Module 4 Chapter___ of this Manual. Evapotranspiration is composed of the evaporation from the soil and the transpiration of the plant. Since under localized irrigation only a portion of the soil is wetted, the evaporation component of evapotranspiration can be reduced accordingly, using the appropriate ground cover reduction factor $\mathrm{Kr}$.

For the design of sprinkler irrigation systems:

$\mathrm{ETc}=\mathrm{ETo} \times \mathrm{Kc}$ 
III. CROP WATER REQUIREMENT

\begin{tabular}{|c|c|c|c|c|c|c|c|c|c|c|c|c|}
\hline Month & $\mathrm{J}$ & $\mathrm{F}$ & $\mathrm{M}$ & A & M & $\mathrm{J}$ & $\mathrm{J}$ & A & $\mathrm{S}$ & 0 & $\mathrm{~N}$ & $\mathrm{D}$ \\
\hline Eto $(\mathrm{mm} / \mathrm{d})$ & 1.4 & 2.2 & 3.6 & 5 & 6.3 & 6.5 & 5.2 & 4.7 & 4.5 & 3.2 & 1.8 & 1.3 \\
\hline & 1.0 & 1.0 & 1.0 & 1.0 & 1.0 & 1.05 & 1.0 & 1.0 & 1.0 & 1.0 & 1.0 & 1.0 \\
\hline Kc Carrot & 5 & 5 & 5 & 5 & 5 & & 5 & 5 & 5 & 5 & 5 & 5 \\
\hline Crop factor $\mathrm{cp}$ & & & & 1 & 1 & 1 & 1 & 1 & 1 & 1 & 1 & 1 \\
\hline CWR (row crop) & $\begin{array}{l}1.4 \\
7\end{array}$ & 2.31 & 3.78 & 5.25 & 6.62 & $\begin{array}{l}6.8 \\
3\end{array}$ & 5.46 & 4.94 & 4.73 & 3.36 & 1.89 & 1.37 \\
\hline Kc (annual crop) & & & & & & & & & & & & \\
\hline $\begin{array}{l}\text { CWR (annual } \\
\text { crop) }\end{array}$ & & & & & & & & & & & & \\
\hline Kc (field crops) & & & & & & & & & & & & \\
\hline CWR (field crops) & & & & & & & & & & & & \\
\hline
\end{tabular}

\section{Step 3. Drawing of Project Area, Selection of zone area and No. of Operations}

A map of the scheme area be drawn and tentative number of zones having equal area of the project be selected to estimate number of operations. It is advisable that area of each of each zone must be equal so that all the discharge coming out from the pump be fully utilized in each zone area. In case all zones are not equal, some additional water has to be sent back to the water storage tank through bypass valve during irrigation of small area zones.

Example:

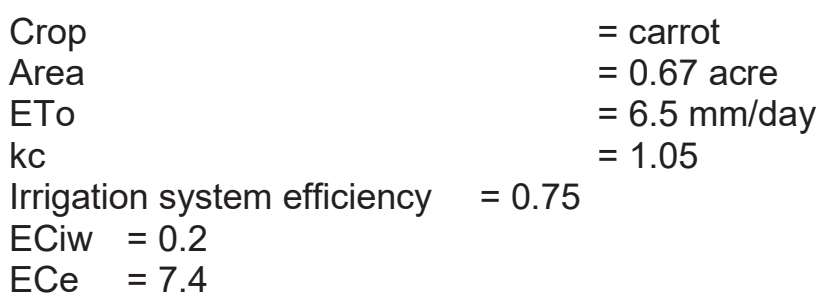

Calculate leaching requirement.

Calculate peak daily consumptive use 


\section{Solution}

Calculated data can be tabulated as under.

\begin{tabular}{|c|c|c|c|c|}
\hline No. & Parameters & Notation/Formula & $\begin{array}{c}\text { Zone } \\
1\end{array}$ & Units \\
\hline 1 & Total area under HEIS & A & 0.67 & Acres \\
\hline 2 & $\begin{array}{l}\text { Reference Evapo- } \\
\text { transpiration }\end{array}$ & ETo & 6.5 & $\mathrm{~mm} / \mathrm{d}$ \\
\hline 3 & Crop Factor & Kc & 1.05 & \\
\hline 5 & Irrigation system efficiency & $\mathbf{N}$ & 75.0 & $\%$ \\
\hline 6 & Quality of Irrigation Water & ECiw & 0.2 & $\mathrm{dS} / \mathrm{m}$ \\
\hline 7 & $\begin{array}{l}\text { Estimated water quality of } \\
\text { root zone that will cause } \\
10 \% \text { yield reduction }\end{array}$ & $\mathrm{ECe}$ & 7.4 & $\mathrm{dS} / \mathrm{m}$ \\
\hline 8 & Leaching Requirements & $\begin{array}{l}\text { LR=ECiw/(5ECe- } \\
\text { ECiw) }\end{array}$ & 0.01 & Fraction \\
\hline 9 & $\begin{array}{l}\text { Peak daily consumptive } \\
\text { use per day }\end{array}$ & $\begin{array}{l}\text { Etc=ETo } \times \mathrm{kc} /(\mathrm{n}) \\
\times(1-\text { LR) }\end{array}$ & 9.15 & $\mathrm{~mm} /$ day \\
\hline
\end{tabular}

\section{Step 4. SELECTION OF SPRINKLER HEAD}

As an example, select a sprinkler rain gun Twin 101 with operating pressure of 60 psi, 24 $\mathrm{mm}$ (0.94 inch) nozzle diameter with a discharge of $198 \mathrm{gpm}$ and sprinkler wetted diameter of 315 feet. Assume a sprinkler overlapping along lateral 100\% and sprinkler overlapping between laterals $65 \%$. Lateral spacing and sprinkler spacing at lateral can be calculated as under.

\section{System is to be designed with KOMET Rain-Gun 101}

\section{Selection of Rain-Gun}

\section{Radius $=41.6 \mathrm{~m}$ at 4.0 bars with $24 \mathrm{~mm}$ Nozzle}

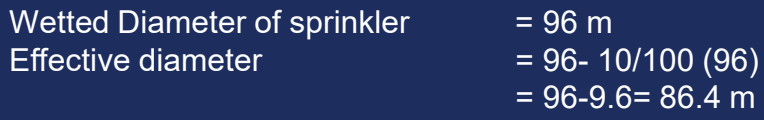

Effect of wind

$=\mathrm{Nil}$ as wind velocity is taken as zero

For Rectangular Pattern:

Sprinkler spacing between lateral/sub-mainline=0.65 x $86.4=56 \mathrm{~m}$

Sprinkler spacing at lateral/sub-mainline $\quad=\quad 0.5 \times 86.4=43 \mathrm{~m}$ 


\begin{tabular}{|c|l|c|l|c|c|}
\hline No. & \multicolumn{1}{|c|}{ Parameters } & $\begin{array}{c}\text { Zone } \\
\mathbf{1}\end{array}$ & \multicolumn{1}{|c|}{ Units } & & \\
\hline 1 & Sprnkler flow rate & 198.0 & $\mathrm{gpm}$ & & \\
\hline 2 & Sprinkler Flow Rate & 44906 & $\mathrm{LPH}$ & $\mathbf{1 2 . 4 7 4}$ & $\mathrm{Ips}$ \\
\hline 3 & Nozzle size & 24 & $\mathrm{~mm}$ & $\mathbf{0 . 9 4}$ & $\mathrm{Inch}$ \\
\hline 4 & Nozzle operating pressure PSI & 41.60 & $\mathrm{~m}$ & $\mathbf{6 0}$ & $\mathrm{psi}$ \\
\hline 5 & Nozzle operating pressure Bars & & & $\mathbf{4}$ & $\mathrm{bar}$ \\
\hline 6 & Wetted diameter of sprinkler & 96.0 & $\mathrm{~m}$ & $\mathbf{3 1 5 . 0}$ & $\mathrm{ft}$ \\
\hline 7 & Wetted radius of sprinkler & 48.0 & $\mathrm{~m}$ & $\mathbf{1 5 7 . 5}$ & $\mathrm{ft}$ \\
\hline 8 & Maximum wind velocity & 6.0 & $\mathrm{~km} / \mathrm{hr}$ & & \\
\hline 9 & Sprinkler overlapping along lateral & 100.0 & $\%$ & & \\
\hline 10 & Sprinkler overlapping between lateral & 65.0 & $\%$ & & \\
\hline 11 & Lateral spacing & 56 & $\mathrm{~m}$ & & \\
\hline 12 & Sprinkler spacing at lateral & 43 & & & \\
\hline 13 & Irrigation cycle (assume one day) & 1.0 & Days & & \\
\hline 14 & Total No. of Sprinkler & 1 & Nos. & & \\
\hline
\end{tabular}

\section{PERFOMANCE DATA - US. UNITS}

\begin{tabular}{|c|c|c|c|c|c|c|c|c|c|c|c|c|c|c|c|c|c|c|c|c|c|c|c|c|}
\hline \multirow{2}{*}{ PSI } & \multicolumn{2}{|c|}{$\begin{array}{l}\text { Nonzle } \\
0.39^{\prime \prime}\end{array}$} & \multicolumn{2}{|c|}{$\begin{array}{l}\text { Nozzle } \\
0.43^{*}\end{array}$} & \multicolumn{2}{|c|}{$\begin{array}{l}\text { Nozze } \\
0.47^{\prime \prime}\end{array}$} & \multicolumn{2}{|c|}{$\begin{array}{l}\text { Notzle } \\
0.51^{*}\end{array}$} & \multicolumn{2}{|c|}{$\begin{array}{l}\text { Nozzle } \\
0.55^{*}\end{array}$} & \multicolumn{2}{|c|}{$\begin{array}{l}\text { Noz2ze } \\
0.59^{*}\end{array}$} & \multicolumn{2}{|c|}{$\begin{array}{l}\text { Nonzle } \\
0.63^{\circ}\end{array}$} & \multicolumn{2}{|c|}{$\begin{array}{l}\text { Nozzle } \\
0.67^{\circ}\end{array}$} & \multicolumn{2}{|c|}{$\begin{array}{l}\text { Nozzle } \\
0.711^{*}\end{array}$} & \multicolumn{2}{|c|}{$\begin{array}{c}\text { Nozzie } \\
0.79^{*}\end{array}$} & \multicolumn{2}{|c|}{$\begin{array}{l}\text { Nozzic } \\
0.87^{\circ}\end{array}$} & \multicolumn{2}{|c|}{$\begin{array}{l}\text { Nozzle } \\
0.94^{*}\end{array}$} \\
\hline & GPM & DIA. & GPM & DIA. & GPM & DIA & GPM & DIA & GPM & DIA. & GPM & DIA. & GPM & DIA & GPM & DIA. & GPM & DIA. & GPM & DIA. & GPM & DIA. & GPM & DIA. \\
\hline 25 & - & - & - & - & 32 & $148^{\circ}$ & 37 & $156^{\prime}$ & 43 & $163^{\circ}$ & 50 & $170^{\prime}$ & 57 & 177 & 64 & $185^{\prime}$ & 72 & $191^{\circ}$ & 89 & $202^{\prime}$ & 107 & $213^{\circ}$ & 128 & $223^{\prime}$ \\
\hline 30 & 24 & $148^{\circ}$ & 29 & $156^{\circ}$ & 35 & 162 & 41 & 171 & 48 & $180^{\prime}$ & 55 & 187 & 62 & 193 & 70 & $2011^{\circ}$ & 79 & $20 \mathrm{r}$ & 97 & $221 \%$ & 118 & $231^{\prime}$ & 140 & $243^{\prime}$ \\
\hline 35 & 26 & $156^{\circ}$ & 32 & $165^{\circ}$ & 38 & $173^{\circ}$ & 44 & $183^{\prime}$ & 51 & 191 & 59 & $199^{\prime}$ & 67 & $205^{\prime}$ & 76 & $214^{\circ}$ & 85 & $221^{\circ}$ & 105 & $237^{\circ}$ & 127 & $244^{\circ}$ & 151 & $256^{\circ}$ \\
\hline 40 & 28 & $163^{\circ}$ & 34 & $174^{\circ}$ & 40 & $182^{\prime}$ & 47 & $193^{\prime}$ & 55 & 201 & 63 & $209^{\circ}$ & 72 & $216^{\circ}$ & 81 & $225^{\circ}$ & 91 & 233 & 112 & $247^{\prime}$ & 135 & $255^{\prime}$ & 162 & $268^{\circ}$ \\
\hline 45 & 30 & $170^{\circ}$ & 36 & $180^{\circ}$ & 43 & $190^{\circ}$ & 50 & $200^{\circ}$ & 58 & $209^{\circ}$ & 67 & $218^{\prime}$ & 76 & $225^{\circ}$ & 86 & $233^{\circ}$ & 96 & $242^{\prime}$ & 119 & 257 & 144 & $265^{\circ}$ & 171 & $279^{\prime}$ \\
\hline 50 & 31 & 177 & 38 & $188^{\prime}$ & 45 & 197 & 53 & 207 & 62 & 213' & 71 & $225^{\circ}$ & 80 & $232^{\circ}$ & 91 & $242^{\prime}$ & 102 & $250^{\circ}$ & 126 & $266^{\prime}$ & 152 & $274^{\circ}$ & 181 & $290^{\circ}$ \\
\hline 55 & 33 & $183^{\circ}$ & 40 & $195^{\circ}$ & 47 & $204^{\circ}$ & 56 & $214^{\circ}$ & 65 & $221 \%$ & 74 & 232 & 84 & $240^{\circ}$ & 95 & $249^{\prime}$ & 107 & 258 & 132 & $274^{\circ}$ & 159 & $285^{\prime}$ & 190 & $300^{\circ}$ \\
\hline 60 & 34 & 191. & 42 & $202^{\prime}$ & 50 & 212 & 58 & 221 & 67 & 229 & 77 & $240^{\circ}$ & 88 & $247^{\circ}$ & 99 & $256^{\circ}$ & 111 & $266^{\circ}$ & 138 & $282^{\circ}$ & 165 & $292^{\prime}$ & 198 & $309^{\circ}$ \\
\hline 65 & 36 & $198^{\circ}$ & 43 & $208^{\prime}$ & 52 & $218^{\circ}$ & 60 & $228^{\circ}$ & 70 & 236 & 81 & 247 & 92 & 254 & 103 & $264^{\circ}$ & 116 & $273^{\circ}$ & 143 & $290^{\circ}$ & 173 & $300^{\circ}$ & 206 & $318^{\prime}$ \\
\hline 70 & 37 & $205^{\prime}$ & 45 & $215^{\circ}$ & 53 & $225^{\circ}$ & 63 & $235^{\circ}$ & 73 & $244^{\circ}$ & 84 & $254^{\prime}$ & 95 & $262^{\prime}$ & 107 & 271 & 120 & $280^{\circ}$ & 148 & 297 & 180 & $30 \mathrm{r}$ & 214 & $323^{\circ}$ \\
\hline 80 & 40 & $216^{\prime}$ & 48 & 227 & 57 & $23 \%$ & 67 & $248^{\circ}$ & 78 & 257 & 89 & $266^{\circ}$ & 102 & $276^{\circ}$ & 115 & $285^{\circ}$ & 129 & $294^{\circ}$ & 159 & $309^{\prime}$ & 192 & 318' & 229 & $343^{\circ}$ \\
\hline 90 & 42 & 227 & 51 & $238^{\prime}$ & 61 & $248^{\circ}$ & 71 & $259^{\circ}$ & 83 & $269^{\circ}$ & 95 & $278^{\circ}$ & 108 & $289^{\circ}$ & 122 & $296^{\prime}$ & 136 & $308^{\circ}$ & 168 & $319^{\circ}$ & 204 & $331^{\circ}$ & 242 & $355^{\circ}$ \\
\hline 100 & 44 & $235^{\circ}$ & 54 & $246^{\prime}$ & 64 & $257^{\circ}$ & 75 & $269^{\prime}$ & 87 & $280^{\circ}$ & 100 & $289^{\circ}$ & 114 & $300^{\circ}$ & 128 & $309^{\circ}$ & 144 & $320^{\circ}$ & 178 & $330^{\circ}$ & 215 & $341^{\circ}$ & 256 & $364^{\prime}$ \\
\hline 110 & 47 & $243^{\prime}$ & 56 & $255^{\circ}$ & 67 & $265^{\circ}$ & 79 & $279^{\circ}$ & 91 & $290^{\circ}$ & 105 & $300^{\circ}$ & 119 & $310^{\circ}$ & 135 & $319^{\prime}$ & 151 & 331. & 186 & $338^{\circ}$ & 225 & $350^{\circ}$ & 268 & $371 \%$ \\
\hline
\end{tabular}

Twin 101 taper bore nozzle, $24^{\circ}$ trajectory

\begin{tabular}{|c|c|c|c|c|c|c|c|c|c|c|c|c|c|c|}
\hline \multirow{2}{*}{ PSI } & \multicolumn{2}{|c|}{$\begin{array}{l}\text { Nozzle } \\
0.47^{\prime \prime}\end{array}$} & \multicolumn{2}{|c|}{$\begin{array}{l}\text { Nozzle } \\
0.55^{*}\end{array}$} & \multicolumn{2}{|c|}{$\begin{array}{l}\text { Nozzle } \\
0.63^{\prime \prime}\end{array}$} & \multicolumn{2}{|c|}{$\begin{array}{l}\text { Nozzle } \\
0.71^{\prime \prime}\end{array}$} & \multicolumn{2}{|c|}{$\begin{array}{l}\text { Nozzle } \\
0.79^{\prime \prime}\end{array}$} & \multicolumn{2}{|c|}{$\begin{array}{l}\text { Nozzle } \\
0.87^{* \prime}\end{array}$} & \multicolumn{2}{|c|}{$\left\langle\begin{array}{c}\text { Nozzle } \\
0.94^{\prime \prime}\end{array}\right.$} \\
\hline & GPM & DIA. & GPM & DIA. & GPM & DIA. & GPM & DIA. & GPM & DIA. & GPM & DIA. & GPM & DIA \\
\hline 30 & - & $\cdot$ & 48 & $187^{\circ}$ & 62 & $201^{\prime}$ & 79 & $217^{\circ}$ & 97 & $232^{\prime}$ & 118 & $247^{\circ}$ & 140 & $260^{\circ}$ \\
\hline 40 & 40 & $183^{\circ}$ & 55 & 203' & 72 & $220^{\circ}$ & 91 & $234^{\prime}$ & 112 & $250^{\circ}$ & 136 & $265^{\prime}$ & 162 & $279^{\circ}$ \\
\hline (50) & 45 & $197^{\circ}$ & 62 & $215^{\circ}$ & 80 & $232^{\prime}$ & 102 & $250^{\prime}$ & 125 & 267 & 152 & $283^{\prime}$ & 181 & $300^{\circ}$ \\
\hline 60 & 50 & $212^{\prime}$ & 67 & $230^{\circ}$ & 88 & $247^{\circ}$ & 111 & $266^{\prime}$ & 138 & $282^{\prime}$ & 167 & $298^{\prime}$ & 198 & 315 \\
\hline 70 & 54 & $225^{\circ}$ & 73 & $244^{\prime}$ & 95 & $262^{\prime}$ & 120 & $280^{\circ}$ & 149 & $297^{\prime}$ & 180 & $314^{\prime}$ & 214 & $323^{\prime}$ \\
\hline 80 & 57 & $237^{\prime}$ & 78 & $257^{\circ}$ & 102 & $276^{\prime}$ & 129 & $294^{\prime}$ & 159 & $312^{\prime}$ & 192 & $329^{\circ}$ & 229 & $344^{\prime}$ \\
\hline 90 & 61 & $248^{\prime \prime}$ & 83 & $269^{\prime}$ & 108 & $289^{\prime}$ & 137 & $308^{\prime}$ & 169 & $326^{\circ}$ & 204 & $343^{\prime}$ & 243 & $359^{\prime}$ \\
\hline 100 & 64 & $257^{\prime}$ & 87 & $280^{\prime}$ & 114 & $300^{\circ}$ & 144 & $320^{\circ}$ & 178 & $339^{\prime}$ & 215 & $357^{\circ}$ & 256 & $374^{\prime}$ \\
\hline 110 & 67 & $265^{\circ}$ & 91 & $290^{\circ}$ & 119 & $310^{\circ}$ & 151 & $331^{\circ}$ & 186 & $351^{\circ}$ & 225 & $369^{\circ}$ & 268 & $388^{\prime}$ \\
\hline
\end{tabular}

\section{Step 4. Calculation of maximum irrigation interval}

As an example, Water holding capacity $=167 \mathrm{~mm} / \mathrm{m}$
MAD
$=50 \%$
Effective crop root depth
Peak daily consumptive use

$$
=0.9 \mathrm{~m}
$$
$=9.15 \mathrm{~mm} /$ day

Calculate maximum irrigation interval 
Solution

The same is given in following table

\begin{tabular}{|c|c|c|c|c|}
\hline No. & Parameters & Notation/Formula & $\begin{array}{c}\text { Zone } \\
1 \text { to } \\
24\end{array}$ & Units \\
\hline 1 & No. of zones & & 24 & \\
\hline 2 & Effective crop Root depth & D & 0.9 & $\mathrm{M}$ \\
\hline 3 & Management Allowed Deficit & MAD & 50.0 & $\%$ \\
\hline 4 & Water holding capacity of soil & WHC & 167.0 & $\mathrm{~mm} / \mathrm{m}$ \\
\hline 5 & Peak daily consumptive use per day & $\begin{aligned} \text { Etc }= & \text { ETo } \times \mathrm{kc} /(\mathrm{n}) \times \\
& (1-\mathrm{LR})\end{aligned}$ & 9.15 & $\mathrm{~mm} / \mathrm{d}$ \\
\hline 6 & $\begin{array}{l}\text { Max. depth of irrigation water that can } \\
\text { be applied }\end{array}$ & $\begin{array}{c}\text { Dmax }=D \times \text { MAD x } \\
\text { WHC/100 }\end{array}$ & 75 & $\mathrm{Mm}$ \\
\hline 7 & Max. irrigation interval & $\mathrm{li}=\mathrm{Dmax} / \mathrm{ETc}$ & 8.2 & Days \\
\hline
\end{tabular}

Step 4. Calculation of Lateral Length and number of sprinklers

As an example, Area $\quad=0.67$ acre

Lateral spacing $\quad=56 \mathrm{~m}$

Sprinkler spacing 45 meter $=45 \mathrm{~m}$

Calculate length of lateral and No. of sprinklers

Length of Lateral and No. of Sprinklers/hydrants

Length of laterals can be calculated using Equation (4.21) as follows

$\mathrm{L}=\mathrm{A} \times \mathrm{K} / \mathrm{LS}$

Total lateral line length $\quad=\quad$ Area in acres $X 4047$ / Lateral spacing

$=0.67 \times 4047 / 56$

$=48 \mathrm{~m}$

Total number of sprinklers/ hydrants required can be calculated using Equation (4.24)

Number of sprinklers $\quad=\quad \mathrm{A} /(\mathrm{S} \times \mathrm{L})$

$=\quad 0.67 \times 4047 /(56 \times 45)$

$=1 \mathrm{No}$. 


\section{A) Total Flow Rate}

Total flow rate for sprinkler system depends upon the number of sprinkler to be operated simultaneously and can be calculated using Equation (4.28).

Total flow rate $\quad=\quad$ No. of sprinkler $X$ Sprinkler flow rate

$$
\begin{array}{ll}
= & 1 \times 44906 \\
= & 44906 \mathrm{LPH} \\
= & 12.47 \mathrm{Ips}
\end{array}
$$

\section{B) Application Rate}

Using equation (4.29) application rate can be calculated as:

Application rate

$$
\begin{array}{ll}
= & \text { Total flow rate } /(\text { Area in acres } \times 4047) \\
= & 44906 /(0.67 \times 4047) \\
= & 16.56 \mathrm{~mm} / \mathrm{hr}
\end{array}
$$

\section{C) Operation Time (hr)}

D)

Total operation time can be calculated using Equation (4.31)

Operation time $\quad=\quad \mathrm{DCU} /$ Application rate

$$
=\quad 9.15 / 16.56
$$

$=0.55 \mathrm{hrs}$

In case the area is 16 acres, 26 no. of sprinklers will be required for which the total flow rate to irrigate 16 acres is $1167556 \mathrm{LPH}$ (324 lps) which is much higher. To deliver this flow rate to the system, larger diameter pipe is required accordingly; high energy will be required, which is economically not feasible. Depending upon the farmer's ease and economics and available power source for the system it is suggested to operate only one rain gun at a time, such that the total area of 16 acres is irrigated in 26 shifts.

Area irrigated in one shift/zone $\quad=\quad$ total area $/$ No. of shifts

$=16 / 26$

$=\quad 0.62$ acres

\section{Sprinkler Design Example}

Design a rain-gun sprinkler system for 43 acres to provide supplemental Irrigation. 
$\begin{array}{ll}\text { Crop: } & \text { Wheat } \\ \text { Soil type : } & \text { Sandy }\end{array}$

Water source: canal + Tubewll

Energy source: Tractor Engine

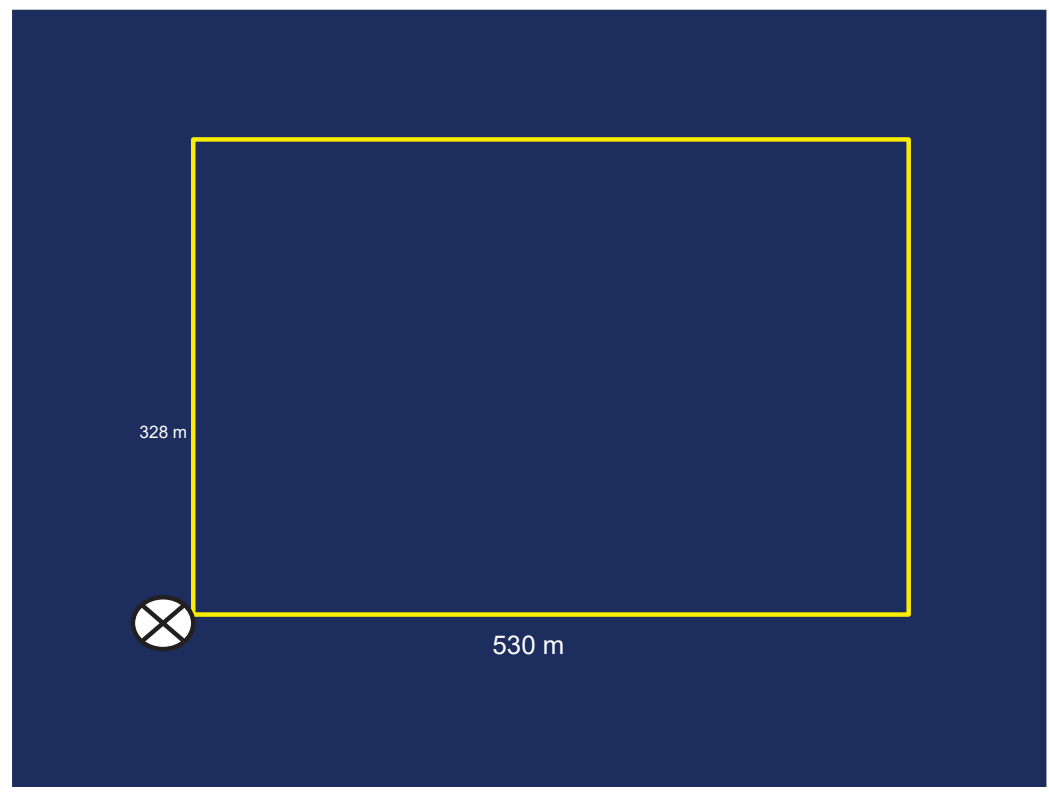

Important: System is to be designed with KOMET Rain-Gun 101

Selection of Rain-Gun

Radius $=\mathbf{4 5} \mathrm{m}$ at 4.0 bars with $24 \mathrm{~mm}$ Nozzle

Wetted Diameter of sprinkler $=90 \mathrm{~m}$

$$
\begin{aligned}
\text { Effective diameter } & =90-10 / 100(90) \\
& =90-9=81 \mathrm{~m}
\end{aligned}
$$

Effect of wind $=$ Nil as wind velocity is taken as zero

For Rectangular Pattern:

Sprinkler spacing between lateral $/$ sub-mainline $\quad=0.65 \times 81=53 \mathrm{~m}$

Sprinkler spacing at lateral $/$ sub-mainline $=0.5 \times 81=41 \mathrm{~m}$ 


\section{SPECIFICATIONS OF TWIN 101}

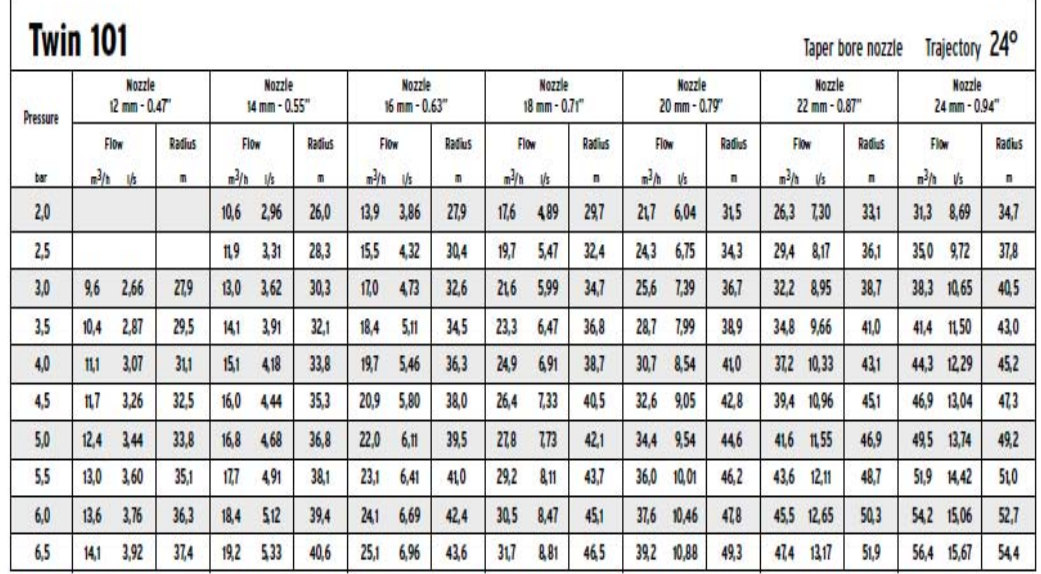

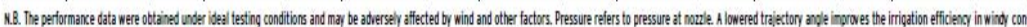

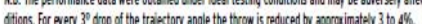

\section{DATA INPUT}

\begin{tabular}{|l|c|c|l|}
\hline Total area under HEIS &, & 43.0 & Acres \\
\hline Design reference evapotranspiration, ETo &, & 4.2 & $\mathrm{~mm} /$ day \\
\hline Design Crop factor at maturity, Kc &, & 0.75 & \\
\hline Plant spacing &, & 0.1 & $\mathrm{~m}$ \\
\hline Row spacing &, & 0.1 & $\mathrm{~m}$ \\
\hline Irrigation system efficiency &, & 75 & $\%$ \\
\hline Quality of irrigation water &, & 4.5 & $\mathrm{dS} / \mathrm{m}$ \\
\hline Estimated water quality of root zone that will cause 10\% & & & $\mathrm{dS} / \mathrm{m}$ \\
\hline yield reduction &, & 7.5 & \\
\hline Effective crop root depth &, & 1.0 & $\mathrm{~m}$ \\
\hline Management allowed deficit &, & 50.0 & $\%$ \\
\hline Water holding capacity of soil &, & 83.0 & $\mathrm{~mm} / \mathrm{m}$ \\
\hline Sprinkler flow rate &, & 44300 & $\mathrm{lph}$ \\
\hline Nozzle size &, & 24 & $\mathrm{~mm}$ \\
\hline Nozzle operating pressure &, & 40 & $\mathrm{~m}$ \\
\hline Wetted diameter of sprinkler/nozzle &, & 81 & $\mathrm{~m}$ \\
\hline Maximum wind velocity &, & 0.0 & $\mathrm{~km} / \mathrm{hr}$ \\
\hline
\end{tabular}

\section{Leaching requirement}

$$
\begin{gathered}
=\text { Ecw } /[\text { [ } 5 \text { Ece }- \text { Ecw ] } \\
=4.5 /[5 \times 7.5-4.5] \\
=0.136
\end{gathered}
$$

\section{Peak Daily Consumptive use per day}

$=$ Eto $\times \mathrm{Kc} /[(1-\mathrm{LR}) \times$ efficiency $]$

$$
=4.2 \times 0.75 /[(1-0.136) \times 0.75]
$$

$$
=4.86 \mathrm{~mm}
$$




$$
\begin{gathered}
\text { Lateral Length } \\
=\text { Area } \times 4047 / \text { Lateral spacing } \\
=43 \times 4047 / 53=3283 \mathrm{~m} \\
\text { Minimum Sprinkler/Hydrants } \\
=\text { Area } \times \text { 4047/[ lateral spacing } \times \text { sprinkler spacing }] \\
=43 \times 4047 /[53 \times 41] \\
=80
\end{gathered}
$$

\section{Total Flow Rate, LPH}

$=$ No. of sprinklers $x$ sprinkler flow rate

$$
\begin{gathered}
=80 \times 44300 \\
=3,544,000 \mathrm{lph}
\end{gathered}
$$

$$
\begin{aligned}
& \text { Application Rate, } \mathrm{mm} / \mathrm{hr} \\
& =\text { Total flow rate/total area } \\
& =3,544,000 /[43 \times 4047] \\
& =20.36 \\
& =\text { SPRINKLER FLOW RATE } /(\mathrm{SL} \times \mathrm{Sm}) \\
& =44300 /(53 \times 41)=20.38 \mathrm{~mm} / \mathrm{hr}
\end{aligned}
$$

\section{Operation Time (when all sprinklers operating together)}

$=$ Peak daily consumptive use/ Application Rate

$$
\begin{gathered}
=4.86 / 20.38 \\
=0.24 \mathrm{hrs}
\end{gathered}
$$

No. of operations/hydro-zones

$=$ total no. of sprinklers or hydrants / no. of sprinklers operating

$$
\begin{gathered}
=80 / 2 \\
=40
\end{gathered}
$$

Total operation time

$=$ No. of operation $x$ operation time for one setting

$$
\begin{aligned}
& =40 \times 0.24 \\
& =9.60 \text { hours }
\end{aligned}
$$



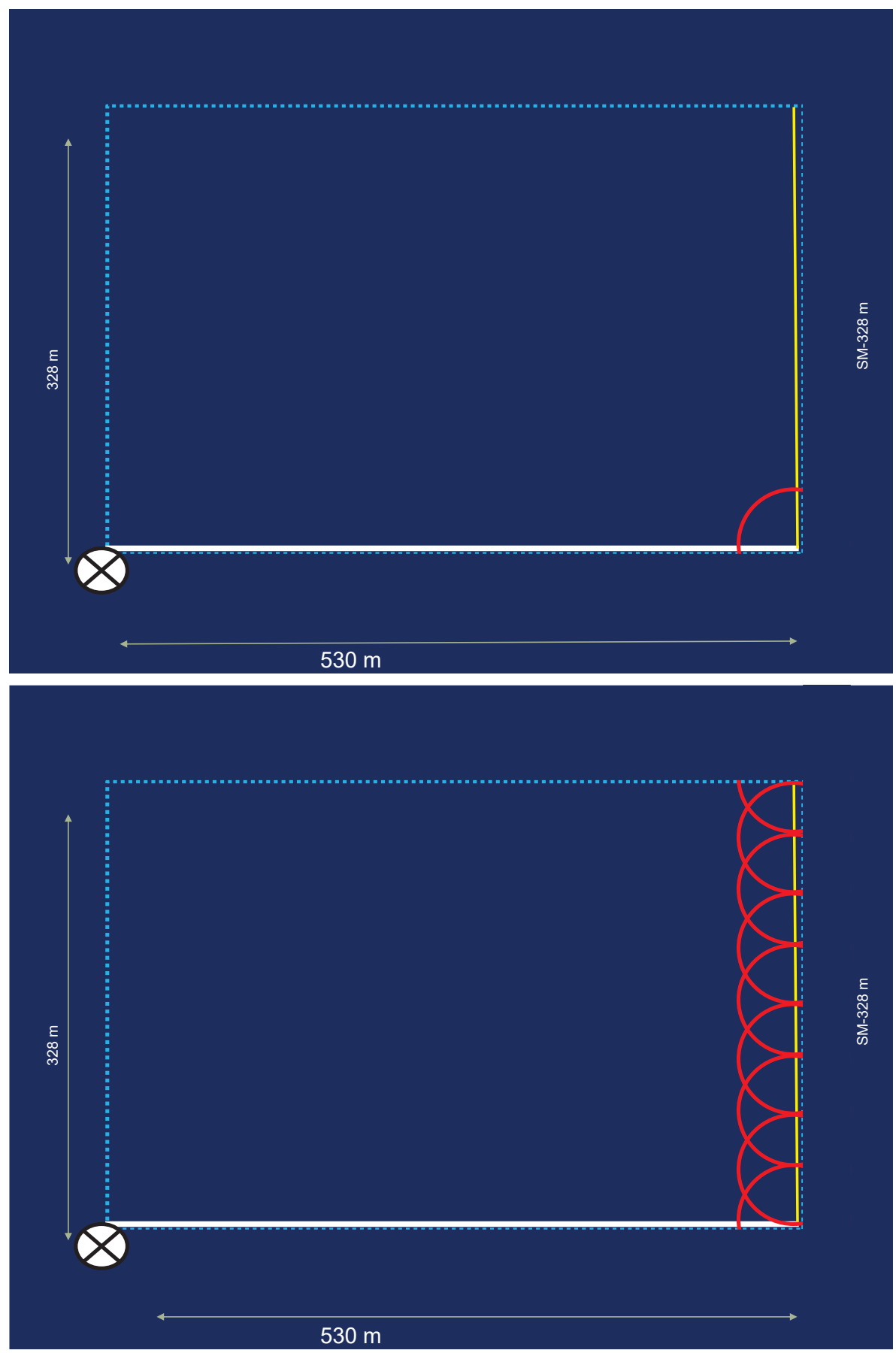

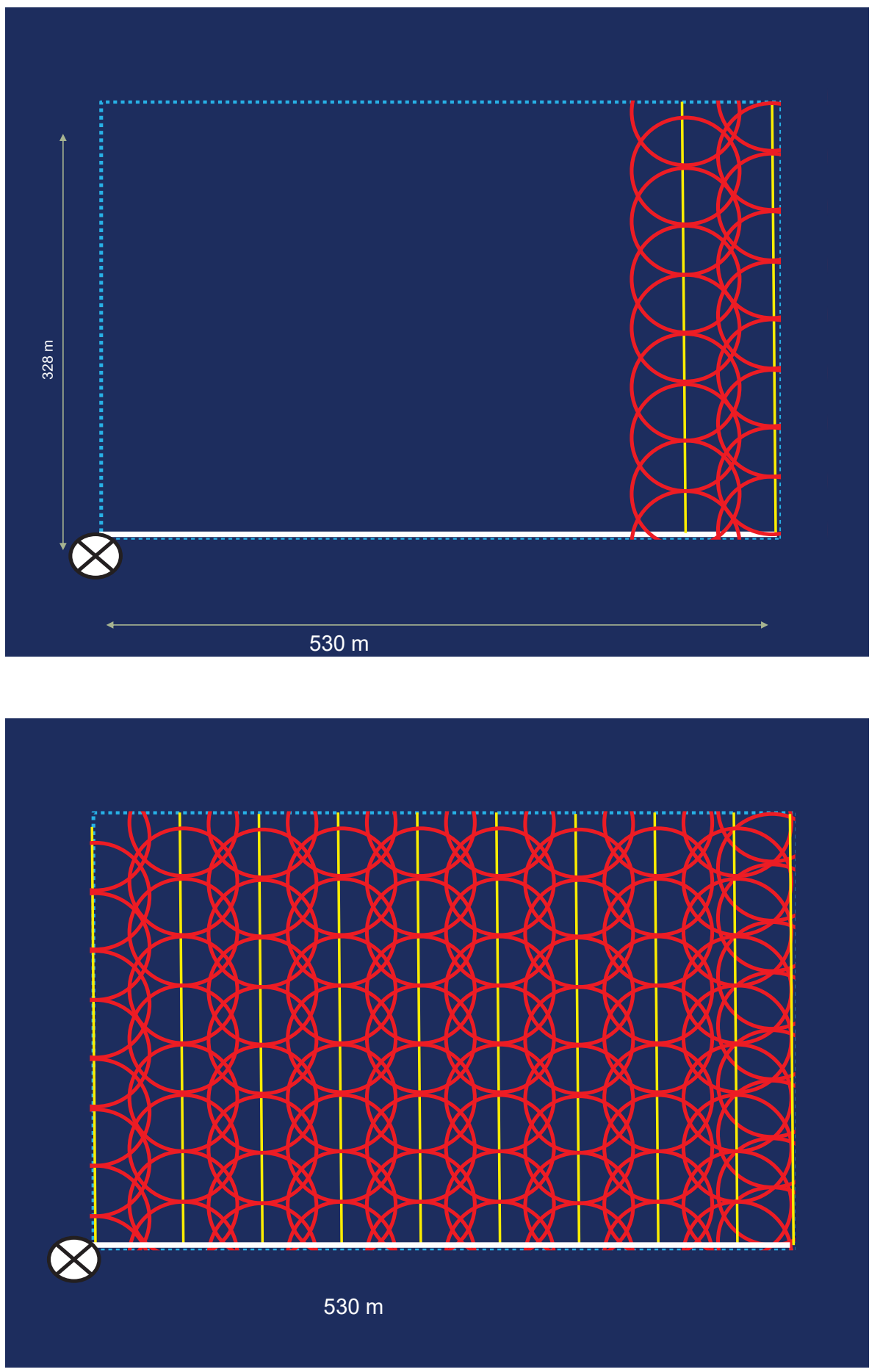


\section{WATERS AND KELLER FORMULA}

\section{For small Pipe less than $125 \mathrm{~mm}$}

$$
\begin{gathered}
\mathrm{J}=100 * \mathrm{hf} / \mathrm{L}=\quad \mathrm{K}(\mathrm{Q})^{1.852} \times \mathrm{D}^{-4.75} \\
\mathrm{~J} \quad=\text { head loss gradient, } \mathrm{m} / 100 \mathrm{~m}
\end{gathered}
$$

$\mathrm{K}=$ Conversion constant, $7.89 * 10^{\wedge} 7$ for metric units

$\mathrm{Hf}=$ Head loss due to pipe friction, $\mathrm{m}$

$L=$ Length of pipe, $m$

$\mathrm{Q}=$ Flow rate in pipe, $\mathrm{L} / \mathrm{S}$

$\mathrm{D}=$ Inside diameter of pipe, $\mathrm{mm}$

For Pipe Greater than $125 \mathrm{~mm}$

$$
\mathrm{J}=100 \text { * } \mathrm{hf} / \mathrm{L}=\quad \mathrm{K}(\mathrm{Q})^{1.83} / \mathrm{D}^{4.83}
$$

$\mathrm{J}=$ head loss gradient, $\mathrm{m} / 100 \mathrm{~m}$

$\mathrm{K}=$ Conversion constant, $9.58 * 10^{7}$ for metric units

$\mathrm{Hf}=$ Head loss due to pipe friction, $\mathrm{m}$

$L=$ Length of pipe in, $m$

$\mathrm{Q}=$ Flow rate in pipe, $\mathrm{L} / \mathrm{S}$

$\mathrm{D}=$ Inside diameter of pipe, $\mathrm{mm}$

\section{Velocity Formula to Determine Pipe Size for Mainline}

$$
\begin{gathered}
\quad v=1.274 q / d^{2} \\
d^{2}=V /(1.274 q) \quad \text { SQRT }[V /(1.274 q)] \\
v=\operatorname{velocity~}(\mathrm{m} / \mathrm{s}) \\
q=\text { volume flow }\left(\mathrm{m}^{3} / \mathrm{s}\right) \\
d=\text { pipe inside diameter }(\mathrm{m})
\end{gathered}
$$

\section{Hydraulic Calculation}

Mainline Head Loss (6" pipe, ID = 154 mm, L= 530 m, Q= 88600 lph)

Using Watters and Keller Eq.

$$
\begin{gathered}
\mathrm{J}=9.58 \times 10^{7} \times \mathrm{Q}^{1.83} / \mathrm{D}^{4.83} \\
\mathrm{~J}=9.58 \times 10^{7} \times(24.6)^{1.83} /(154)^{4.83} \\
=0.91 \mathrm{~m} / 100 \mathrm{~m} \\
=0.91 / 100 \times 530=4.823 \mathrm{~m} \\
v=1.274 \mathrm{q} / \mathrm{d}^{2}=1.274 \times(0.0246) /(0.154 \times 0.154) \\
v=\text { velocity }(\mathrm{m} / \mathrm{s}) \\
q=\text { volume flow }\left(\mathrm{m}^{3} / \mathrm{s}\right) \\
d=\text { pipe inside diameter }(\mathrm{m})
\end{gathered}
$$




$$
\text { Velocity }=1.32 \mathrm{~m} / \mathrm{s}
$$

Using Watters and Keller Eq.

Sub-Mainline Head Loss (4", ID = 105 mm, L= 328m, Q= 44300 Iph)

$$
\begin{gathered}
\mathrm{J}=7.89 \times 10^{7} \times \mathrm{Q}^{1.852} / \mathrm{D}^{4.75} \\
\mathrm{~J}=7.89 \times 10^{7} \times(12.3)^{1.852} /(105)^{4.75} \\
=2.06 \mathrm{~m} / 100 \mathrm{~m} \\
=2.0 / 100 \times 328=6.56 \mathrm{~m} \\
\text { Velocity }=1.42 \mathrm{~m} / \mathrm{s}
\end{gathered}
$$

\section{TOTAL DYNAMIC HEAD}

Sprinkler operating pressure

Elevation difference

Head loss in lateral

Head loss in sub-mainline

Head loss in mainline

Head loss in filter

Head loss in hydrant

Head loss in fertigation system

Head loss in flow meter

Field fitting losses

Miscellaneous head loss, if any

Pumping lift

Total Head Requirement (Approximately)

\section{Pump Requirement}

$$
\begin{gathered}
\mathrm{Q}=88600 \mathrm{Iph} \\
=24.6 \mathrm{Ips} \\
\mathrm{H}=53 \mathrm{~m} \\
\mathrm{HP}=24.6 \times 53 /(75 \times 0.7 \times 0.5)
\end{gathered}
$$

50 


\section{BILL OF QUANTITIES}

\begin{tabular}{|c|l|l|l|l|l|l|}
\hline S.N & Description & $\begin{array}{l}\text { Standard/ } \\
\text { specification }\end{array}$ & Unit & Quantity & Rate (Rs.) & Cost (Rs.) \\
\hline $\mathbf{1}$ & Pump set & $25 \mathrm{LPS}, 51 \mathrm{M}$ & No & 01 & & \\
\hline $\mathbf{2}$ & Flow Meter & $100 \mathrm{M} 3 / \mathrm{hr}$ & & 01 & & \\
\hline $\mathbf{3}$ & Pressure Gauges & & & 03 & & \\
\hline $\mathbf{4}$ & Air Release valves & & & 02 & & \\
\hline $\mathbf{5}$ & NRV & & & 01 & & \\
\hline $\mathbf{6}$ & Foot valve & & & 01 & & \\
\hline $\mathbf{7}$ & GI Hydrants with brass valves & 2 inches, 2m & Nos. & 80 & & \\
\hline $\mathbf{8}$ & Flow control valves & 4 inches & Nos. & 11 & & \\
\hline $\mathbf{9}$ & GI Fittings & $160 \mathrm{~mm}$ & L/s & 1 & & \\
\hline $\mathbf{1 0}$ & PVC Pipe, B Class & $160 \mathrm{~mm}$ & $\mathrm{~m}$ & 530 & & \\
\hline $\mathbf{1 1}$ & PVC Pipe, B Class & $110 \mathrm{~mm}$ & $\mathrm{~m}$ & 3280 & & \\
\hline $\mathbf{1 2}$ & Rain Guns & Twin 101 & Nos. & 03 & & \\
\hline $\mathbf{1 3}$ & Trenching & & & & & \\
\hline $\mathbf{1 4}$ & $\begin{array}{l}\text { Civil works for head unit \& Hydrants } \\
\text { reinforcement }\end{array}$ & & LS. & & & \\
\hline & Sub-Total & & & & & \\
\hline & Service charges (Design, Installation, Service) & $8 \%$ of total & & & & \\
\hline $\mathbf{G r a n d ~ T o t a l ~}$ & & & & \\
\hline
\end{tabular}

\subsection{SELECTION OF PUMP}

Pump is selected based on the discharge and total dynamic head. The selection process involves finding an economic pumping plant that will provide required discharge and head and also operate at high efficiency. Pump characteristic curves developed by the manufacturers provide the ready reference for selection of most efficient pumping unit.

Horse power requirement can be calculated as

\section{$H . P=\quad$ Q. $H /[75 \times E m \times E p]$}

$\begin{array}{lll}\mathrm{Q} & = & \text { Flow rate, Ips } \\ \mathrm{H} & = & \text { Total dynamic head, } \mathrm{m} \\ \mathrm{Em} & = & \text { Motor efficiency (fraction) } \\ \mathrm{Ep} & = & \text { Pump efficiency (fraction) }\end{array}$

Electric motor efficiency is generally taken as $80 \%$.

Diesel engine efficiency is generally take as $40-50 \%$

Pump efficiency is generally taken as $50-75 \%$. 


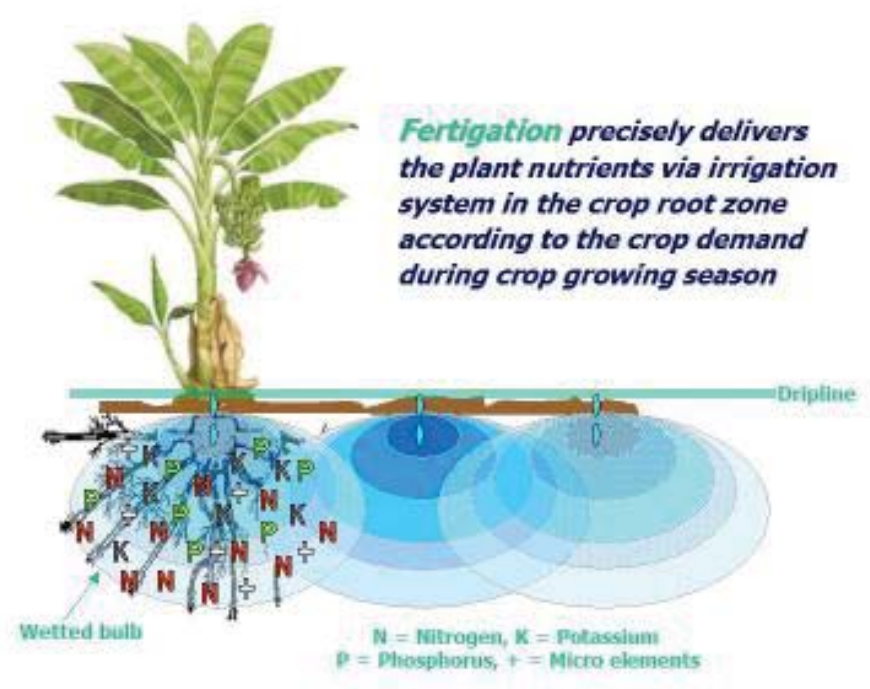

\subsection{Design of Sprinkler Irrigation System - Example 2}

Design a Rain Gun sprinkler system for wheat crop on a rectangular area of dimensions $880 \mathrm{ft}$ $X 795 \mathrm{ft}$ with the following available data:

\section{Given Data:}

Growing season $\quad$ - $\quad$ N N November to May

Soil Type

- Loam

Ec of water

- $\quad 0.20 \mathrm{dS} / \mathrm{m}$

Max. Wind velocity

- $\quad 6 \mathrm{Km} / \mathrm{hr}$

Komet Twin-101 rain gun is selected having following specifications:

Nozzle diameter

Flow rate

Nozzle operating pressure

Wetted radius
- $24 \mathrm{~mm}$

- $\quad 44244$ LPH (Liter per Hour)

- $\quad 4.0$ bar

$45.2 \mathrm{~m}$

\section{Design Calculations:}

\section{A) Leaching Requirement}

LR can be calculated using equation 3.8 as given below

$$
L R=\frac{E C_{w}}{5\left(E C_{e}\right)-E C_{w}}
$$

Estimated water quality of root zone that will cause $10 \%$ yield reduction for wheat crop is taken from the Table-3.8, which is $7.4 \mathrm{dS} / \mathrm{m}$. 


$$
=0.2 / 5[7.4-0.2]=0.01
$$

\section{B) Crop Water Requirement}

Crop water requirement is calculated by multiplying ETo and Kc values for each month of the growing season of the wheat crop. ETo values in mm per day for each month of the year and Kc values of the growing season of the selected area can be selected from Tables given in Crop Water Requirement Manual. For designing purpose select the maximum crop water requirement (CWR) value. For wheat the maximum CWR value comes in the month of February so the ETo and $\mathrm{Kc}$ values of this month are incorporated in the design sheet.

Peak daily consumptive use (CU) per day is calculated using equation as follows:

CU

$$
\begin{array}{ll}
= & \text { ETo } \times \mathrm{Kc} \times \mathrm{Kf} / \text { [efficiency } \times(1-\mathrm{LR})] \\
= & 2.2 \times 1.2 \times 1 /(0.75 \times(1-0.01) \\
= & 3.56 \mathrm{~mm} / \text { day }
\end{array}
$$

Irrigation system efficiency for sprinkler system is taken from the Table-3.4 giving range (60$85 \%$ ) the average value $75 \%$ is generally used for high pressure sprinkler system such as Rain-Gun.

\section{C) Sprinkler Pattern/ Spacing}

$100 \%$ of sprinkler overlapping is selected along lateral while $65 \%$ overlapping is selected between laterals. Using this type of overlapping the sprinkler to sprinkler and lateral to lateral spacing is calculated as below:

$\begin{array}{lll}\text { Sprinkler Spacing } & & 0.50 \times \text { Wetted dia. of sprinkler } \\ & = & 0.50 \times(2 \times 45.2) \\ & & 45.2 \mathrm{~m} \\ \text { Lateral Spacing } & & \\ & =0.65 \times \text { Wetted dia. of sprinkler } \\ & =58.65(2 \times 45.2) \\ & & \end{array}$

\section{D) Length of Lateral and No. of Sprinklers/hydrants}

Length of laterals can be calculated using Equation (4.21) as follows

$$
\mathrm{L}=\mathrm{A} \times \mathrm{K} / \mathrm{Ls}
$$

Total lateral line length $\quad=\quad$ Area in acres X 4047 / Lateral spacing

$=16 \times 4047 / 58.76$

$=1102 \mathrm{~m}$ 
Total number of sprinklers/ hydrants required can be calculated using Equation (4.24)

$\begin{aligned} \text { Number of sprinklers }=\quad & A /(S \times L) \\ & =\quad 16 \times 4047 /(58.76 \times 45.2) \\ & =\quad 24.4 \text { say } 25 \text { Nos. }\end{aligned}$

\section{E) Total Flow Rate}

Total flow rate for sprinkler system depends upon the number of sprinkler to be operated simultaneously and can be calculated using Equation.

Total flow rate $\quad=\quad$ No. of sprinkler $X$ Sprinkler flow rate

$$
\begin{array}{ll}
= & 25 \times 44244 \\
= & 1106100 \mathrm{LPH}
\end{array}
$$

\section{F) Application Rate}

Using equation application rate can be calculated as:

Application rate

$$
\begin{array}{ll}
= & \text { Total flow rate } /(\text { Area in acres } X 4047) \\
= & 1106100 /(16 \times 4047) \\
= & 17.08 \mathrm{~mm} / \mathrm{hr}
\end{array}
$$

\section{G) Operation Time (hr)}

Total operation time can be calculated using Equation.

Operation time

$$
\begin{array}{ll}
= & \text { DCU / Application rate } \\
= & 3.56 / 17.08 \\
= & 0.21 \mathrm{hrs}
\end{array}
$$

As 25 no. of sprinklers are required for which the total flow rate to irrigate 16 acres is 1106100 $\mathrm{LPH}$ which is much higher. To deliver this flow rate to the system, larger diameter pipe is required accordingly; high energy will be required, which is economically not feasible. Depending upon the farmer's ease and economics and available power source for the system it is suggested to operate only one rain gun at a time, such that the total area of 16 acres is irrigated in 25 shifts.

Area irrigated in one shift/zone $\quad=\quad$ total area $/$ No. of shifts

$=16 / 25$

$=\quad 0.64$ acres

\section{H) Maximum irrigation Depth}

Maximum irrigation depth $(\mathrm{dx})$ can be calculated using Equation (4.12)

$\mathrm{dx} \quad=\quad \operatorname{MAD}(\mathrm{Wa} \times \mathrm{Z}) / 100$ 
Effective rooting depth of wheat crop is taken from Table-4.4 which is $1.2 \mathrm{~m}$.

Management Allowed Deficit is taken from the Table-3.2 which is $25 \%$

Water holding capacity for loam soil is taken from Table-3.1 which is $170 \mathrm{~mm} / \mathrm{m}$

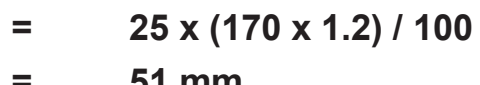

$=\quad 51 \mathrm{~mm}$

\section{I) Maximum Irrigation Interval}

Maximum irrigation interval can be calculated using Equation 4.13.

$F \mathbf{x}=\mathbf{d x} / \mathbf{C u}$
$F x=51 / 3.56=14$ days

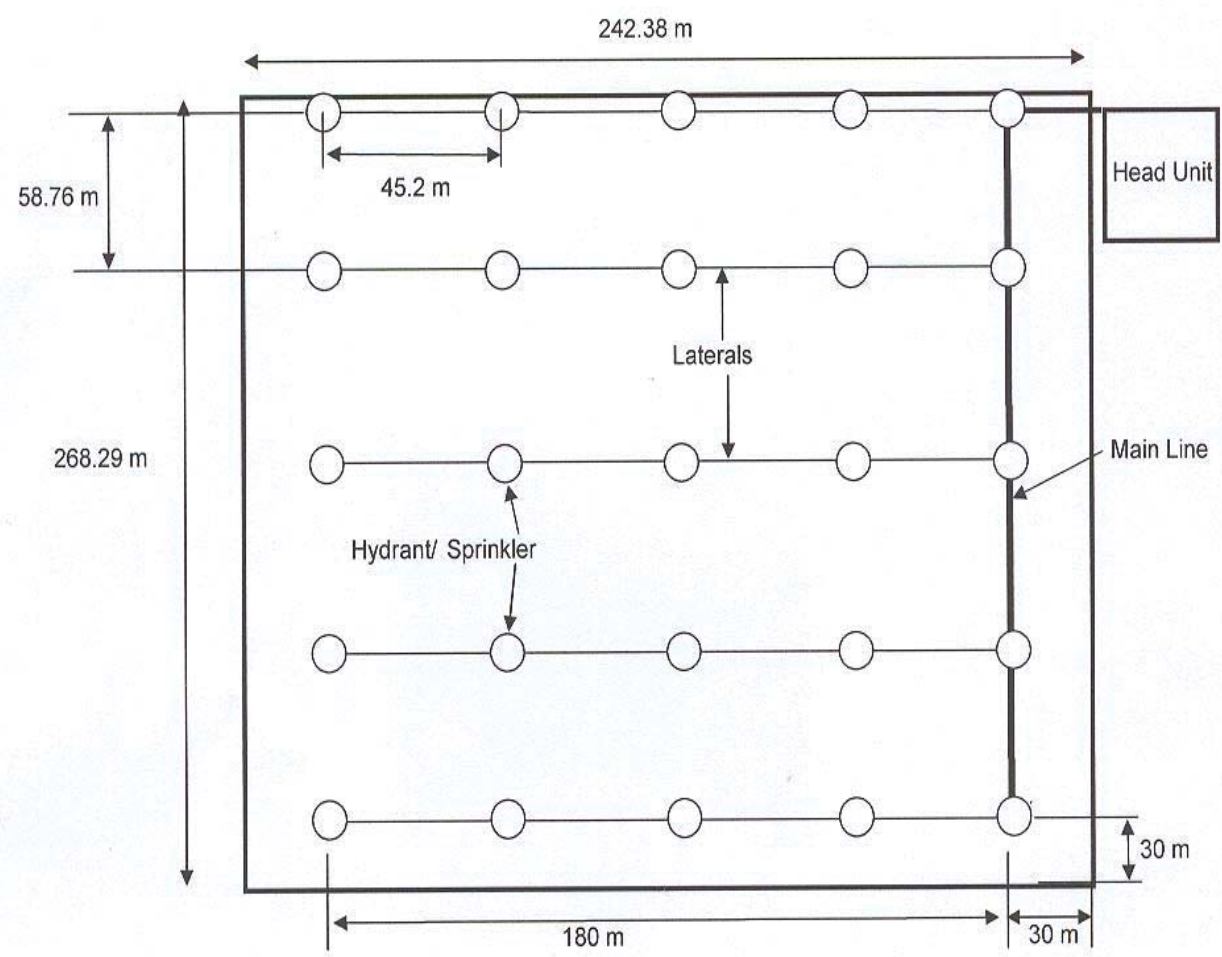

Design layout for sprinkler irrigation system 
All the above calculated values are arranged in the form of table for design as flows:

\begin{tabular}{|c|c|c|c|c|}
\hline $\begin{array}{l}\text { Sr. } \\
\text { No. }\end{array}$ & Parameters & Units & $\begin{array}{c}\text { Zone } \\
\text { (1 to } 24)\end{array}$ & Total \\
\hline 1 & Total Area & Acres & 0.64 & 16 \\
\hline 2 & Design Reference Evapotranspiration, ETo & $\mathrm{mm} /$ day & 2.2 & \\
\hline 3 & Design crop factor at maturity, Kc & - & 1.2 & \\
\hline 4 & Irrigation system efficiency & $\%$ & 75 & \\
\hline 5 & Quality of irrigation water & $\mathrm{dS} / \mathrm{m}$ & 0.20 & \\
\hline 6 & $\begin{array}{l}\text { Estimated water quality of root zone that will } \\
\text { cause } 10 \% \text { yield reduction }\end{array}$ & $\mathrm{dS} / \mathrm{m}$ & 7.4 & \\
\hline 7 & Effective crop root depth & $\mathrm{m}$ & 1.2 & \\
\hline 8 & Management Allowed Deficit & $\%$ & 25 & \\
\hline 9 & Water holding capacity of soil & $\mathrm{mm} / \mathrm{m}$ & 170 & \\
\hline 10 & Leaching requirement & fraction & 0.01 & \\
\hline 11 & Maximum wind velocity & $\mathrm{Km} / \mathrm{hr}$ & 6 & \\
\hline 12 & Sprinkler flow rate & $\mathrm{LPH}$ & 44244 & 44244 \\
\hline 13 & Nozzle size & $\mathrm{mm}$ & 24 & \\
\hline 14 & Nozzle operating pressure & $\mathrm{m}$ & 40 & \\
\hline 15 & Wetted radius of sprinkler & $\mathrm{m}$ & 45.2 & \\
\hline 16 & Sprinkler overlapping along lateral & $\%$ & 100 & \\
\hline 17 & Sprinkler overlapping between lateral & $\%$ & 65 & \\
\hline 18 & Sprinkler spacing at lateral & $\mathrm{m}$ & 45.2 & \\
\hline 19 & Lateral spacing & $\mathrm{m}$ & 58.76 & \\
\hline 20 & Irrigation Cycle & days & 1 & \\
\hline 21 & Peak daily consumptive use per day & $\mathrm{mm} /$ day & 3.52 & \\
\hline 22 & Total no. of sprinklers & No. & 1 & \\
\hline 23 & Total flow rate & $\mathrm{LPH}$ & 44244 & \\
\hline 24 & Application rate & $\mathrm{mm} / \mathrm{hr}$ & 17.08 & \\
\hline 25 & Operation time & hrs & 0.21 & 5.04 \\
\hline
\end{tabular}

\section{J) Head Loss Calculations}

The maximum lateral line length to be laid at site is $180 \mathrm{~m}$ (see layout) while only one number of sprinkler is to be operate on a lateral for which the flow rate is $44244 \mathrm{LPH}$. The diameter of pipe required to deliver this amount of water shall be selected such that the head loss may be less than $20 \%$ of the sprinkler operating pressure or the velocity shall not exceed $1.5 \mathrm{~m} / \mathrm{s}$. A 4 " pipe diameter is selected for which the head loss can be calculated by using equations as illustrated in Exapmle-1. 
Lateral Head Loss for 100m length using Hazzen William's equation= $1.49 \mathrm{~m}$

Lateral Head Loss for $180 \mathrm{~m}$ length using Hazzen William's equation $=\quad 2.68 \mathrm{~m}$

Average lateral head loss for $180 \mathrm{~m}$ of length $\quad=\quad 2.62 \mathrm{~m}$

The total length of main line pipe to deliver water to the remotest lateral is $325 \mathrm{~m}$ (see layout) which will also be used to carry water flow rate of $44244 \mathrm{LPH}$ to each outlet point in the pipe network, so similar sized pipe can be used for lateral and mainline.

As the flow rate and diameter of pipe is same and only the length is changed so that the head loss for $325 \mathrm{~m}$ of length can be given as:

Main line head loss for $325 \mathrm{~m}$ of length $\quad=\quad 4.90 \mathrm{~m}$

The head loss for suction and delivery pipe for pump be calculated using the same equation.

Suction and delivery head loss

Total head losses in piping network

Fitting losses

(may be taken $20 \%$ of the pipe losses)

Sprinkler operating pressure in form of water head
$=0.09 \mathrm{~m}$

$=\quad 2.62+4.90+0.09$

$=7.61 \mathrm{~m}$

$=\quad 1.52 \mathrm{~m}$

$=40 \mathrm{~m}$

Head losses for fittings, filters, fertigation system and other flow control and monitoring devices shall be included as given by the manufacturers. For example

Head loss in fertigation

Head loss in flow meter

Misc. head losses

$\begin{array}{ll}= & 5 \mathrm{~m} \\ = & 1 \mathrm{~m} \\ = & 2 \mathrm{~m}\end{array}$

The total dynamic head can be calculated by adding all the head losses occurring in the system and can be presented as follow:

Total Dynamic Head

$=\quad 57.13 \mathrm{~m}$

\section{K) Power requirements}

Horse Power Requirement can be calculated using equation - 5.6

$$
\begin{array}{ll}
= & 44244(\mathrm{LPH}) / 3600(\mathrm{Sec} .) \\
= & 12.29 \mathrm{LPS}
\end{array}
$$

The efficiencies for pump and electric motor are assumed as $60 \%$ and $80 \%$ respectively. 


\section{References}

Consultants will furnish references on request. 